\title{
Baseline Risk Assessment of GROUND WATER CONTAMINATION at THE URANIUM MILL TAILINGS Site Near Durango, Colorado
}

February 1995 


\title{
INTENDED FOR PUBLIC RELEASE
}

This report has been reproduced from the best available copy. Available in paper copy and microfiche.

Number of pages in this report: 241

DOE and DOE contractors can obtain copies of this report from:

Office of Scientific and Technical Information

P.O. Box 62

Oak Ridge, TN 37831

(615) 576-8401

This report is publicly available from:

\author{
National Technical Information Service \\ Department of Commerce \\ 5285 Port Royal Road \\ Springfield, VA 22161 \\ (703) $487-4650$
}




\title{
BASELINE RISK ASSESSMENT OF GROUND WATER CONTAMINATION AT THE URANIUM MILL TAILINGS SITE NEAR DURANGO, COLORADO
}

February 1995

\author{
Prepared for \\ U.S. Department of Energy \\ UMTRA Project Office \\ Albuquerque, New Mexico \\ Prepared by \\ Jacobs Engineering Group Inc. \\ Albuquerque, New Mexico
}

\section{DISCLAIMER}

This report was prepared as an account of work sponsored by an agency of the United States Government. Neither the United States Government nor any agency thereof, nor any of their employees, makes any warranty, express or implied, or assumes any legal liability or responsibility for the accuracy, completeness, or usefulness of any information, apparatus, product, or process disclosed, or represents that its use would not infringe privately owned rights. Reference herein to any specific commercial product, process, or service by trade name, trademark, manufacturer, or otherwise does not necessarily constitute or imply its endorsement, recommendation, or favoring by the United States Government or any agency thereof. The views and opinions of authors expressed herein do not necessarily state or reflect those of the United States Government or any agency thereof. 


\section{DISCLAIMER}

Portions of this document may be illegible in electronic image products. Images are produced from the best available original document. 


\section{CITIZENS' SUMMARY}

This risk assessment evaluates the possibility of health and environmental risks from contaminated ground water at the uranium mill tailings site near Durango, Colorado. The former uranium processing site's contaminated soil and material were removed and placed at a disposal site located in Bodo Canyon, Colorado, during 1986-1991 by the U.S. Department of Energy's Uranium Mill Tailings Remedial Action (UMTRA) Project. Currently, the UMTRA Project is evaluating the nature and extent of ground water contamination at the site.

No drinking water wells exist in the contaminated ground water. Because no one is drinking this contaminated ground water, there are currently no health problems from it. This situation will continue if land use and water use at the site do not change. There is not enough information, however, to determine whether wildlife and plants are being affected by the ground water. Because future land use at the site is not known, this risk assessment looks at the possibility of people drinking the water in the future and evaluates possible health risks. Note, however, that it is unlikely that people will use this ground water for drinking because water is provided by the city for this area.

This risk assessment follows an approach similar to that used by the U.S. Environmental Protection Agency. The first step is to determine what site-related contaminants are found in ground water samples. The main contaminants found in the ground water at levels that may affect health are sulfate, manganese, molybdenum, sodium, lead, arsenic, and uranium.

The next step in the risk assessment is to determine how much of these contaminants people might ingest if they got their drinking water from a well on the site. In accordance with standard practice for this type of risk assessment, the highest contaminant concentrations from the most contaminated wells are used. The risk assessment then explains the possible health problems that could result from this amount of contamination. Health problems from short-term as well as long-term exposure are evaluated, because different contaminants may flush out through ground water at different rates. It was found that the sulfate levels in the ground water could cause severe diarrhea and dehydration in adults and could be life threatening for infants if the ground water were ingested for a short time. In addition, it was found that manganese, molybdenum, sodium, and lead could cause health problems if the ground water were ingested for a long time. However, these contaminants make the water taste unpleasant, which would discourage use.

There would be an increased possibility of cancer from a lifetime consumption of ground water due to the levels of uranium and arsenic.

Wells at the site are routinely sampled to check for any changes in ground water chemistry. Additional information about the ground water and how it moves will be collected. This risk assessment and future investigations will be used to determine how to deal with contaminated ground water at the site. Meanwhile, future use of the contaminated ground water should be restricted. 


\section{TABLE OF CONTENTS}

Section

Page

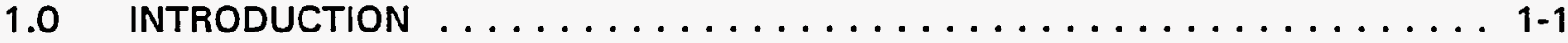

2.0 SITE DESCRIPTION ........................... 2-1

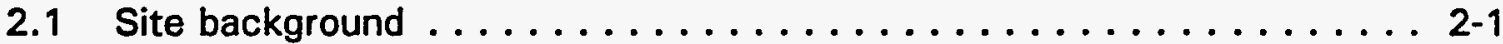

2.2 Climate ................................ 2-3

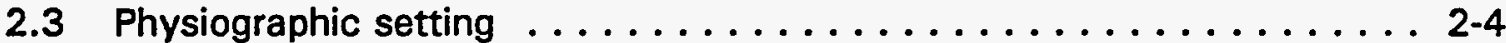

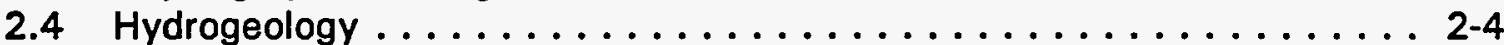

2.4.1 Mill tailings area ...................... 2-4

2.4 .2 Raffinate ponds area .................... 2-10

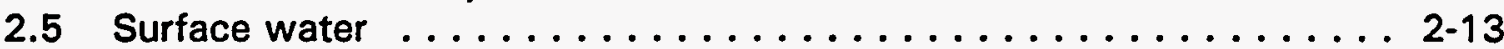

2.6 Land use .................................. 2-14

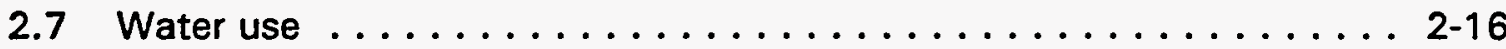

3.0 MAGNITUDE AND EXTENT OF CONTAMINATION $\ldots \ldots \ldots \ldots \ldots \ldots \ldots$

3.1 Background water quality summary ................. 3-16

3.2 Magnitude of site-related contamination ................ 3-19

3.3 Contaminants of potential concern ................. 3-31

3.4 Contaminant fate and transport ................... 3-40

3.5 Surface water monitoring ..................... 3-49

3.6 Ground water discharge modeling . . . . . . . . . . . . 3-56

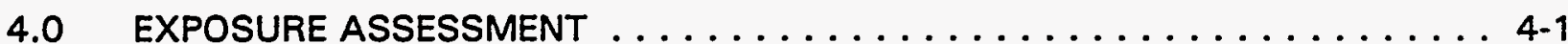

4.1 Potentially exposed population ..................... . . . . .

4.2 Exposure pathways ....................... 4-2

4.2.1 Drinking water ingestion $\ldots \ldots \ldots \ldots \ldots \ldots \ldots \ldots \ldots$ 4-2

4.2.2 Dermal absorption .................... 4-4

4.2 .3 Produce ingestion . . . . . . . . . . . . . . . 4-4

4.2 .4 Meat ingestion $\ldots \ldots \ldots \ldots \ldots \ldots \ldots \ldots \ldots \ldots \ldots \ldots$

4.2 .5 Fish ingestion ..................... 4-5

4.3 Exposure concentrations ...................... 4-6

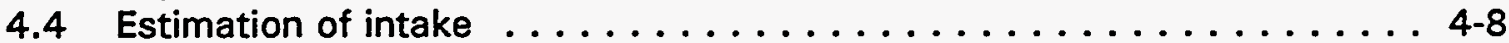

4.5 Exposure assessment uncertainties $\ldots \ldots \ldots \ldots \ldots \ldots \ldots \ldots \ldots \ldots$. . . . . . .

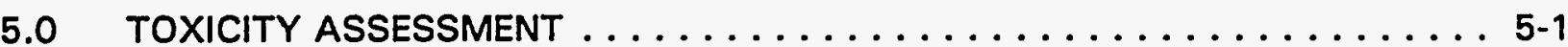

5.1 Contaminant toxicity summaries $\ldots \ldots \ldots \ldots \ldots \ldots \ldots \ldots \ldots \ldots \ldots$

5.1 .1 Antimony ....................... $5-1$

$5.1 .2 \quad$ Arsenic ........................ 5 .

$5.1 .3 \quad$ Cadmium ........................ 5 .7

$5.1 .4 \quad$ Chloride ........................ 5-12

$5.1 .5 \quad$ Lead .......................... 5 5.13

5.1 .6 Manganese ...................... 5.19

5.1 .7 Molybdenum ..................... 5.23

5.1 .8 Selenium ....................... 5-25

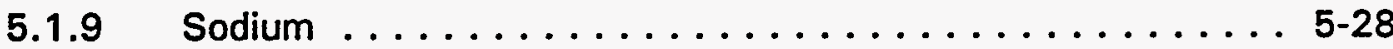




\section{TABLE OF CONTENTS (Concluded)}

Section

Page

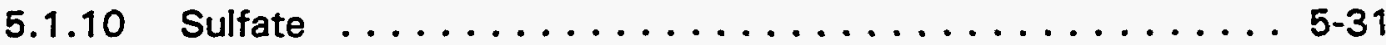

5.1 .11 Thallium .................... 5-33

5.1 .12 Uranium .................... 5-37

5.1 .13 Vanadium ..................... 5-41

5.2 Contaminant interactions . . . . . . . . . . . . . . . . 5 545

5.3 Contaminant risk factors . . . . . . . . . . . . . . . . 5-48

6.0 HUMAN HEALTH RISK EVALUATION $\ldots \ldots \ldots \ldots \ldots \ldots \ldots \ldots \ldots \ldots$

6.1 Potential noncarcinogenic health effects . . . . . . . . . . . . . 6-1

6.2 Potential carcinogenic health effects . . . . . . . . . . . . . 6-16

6.3 Limitations of risk evaluation .................. 6-16

7.0 ECOLOGICAL RISK EVALUATION $\ldots \ldots \ldots \ldots \ldots \ldots \ldots \ldots \ldots \ldots \ldots$

7.1 Exposure characterization $\ldots \ldots \ldots \ldots \ldots \ldots \ldots \ldots \ldots \ldots \ldots \ldots$

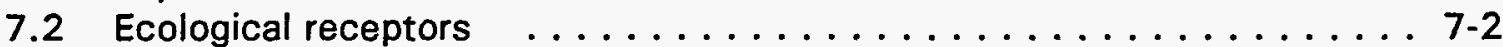

7.2.1 Terrestrial resources .................. 7-3

7.2 .2 Aquatic organisms ................. $7-4$

7.2.3 Threatened and endangered species ............ 7-4

7.3 Contaminants of ecological concern ................ 7-5

7.3.1 Ground water .................... 7-5

7.3.2 Surface water and sediment $\ldots \ldots \ldots \ldots \ldots \ldots \ldots \ldots$

7.3.3 Fish tissue data .................. 7-10

7.4 Potential impacts to wildlife and plants . . . . . . . . . . . 7-10

7.4.1 Terrestrial risk ..................... 7-10

7.4 .2 Aquatic risk .................... . . . . . . . . . . . .

7.5 Limitations of the ecological risk assessment . . . . . . . . 7-16

7.6 Summary ........................ $7-16$

8.0 INTERPRETATION AND RECOMMENDATIONS $\ldots \ldots \ldots \ldots \ldots \ldots \ldots$

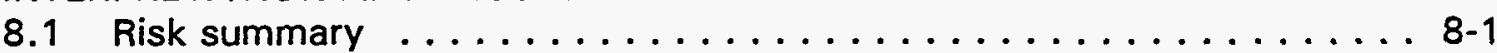

8.2 Limitations of this risk assessment . . . . . . . . . . . . . . . 8 8-2

8.3 Ground water criteria ........................ 8.4

8.4 Risk mitigation measures $\ldots \ldots \ldots \ldots \ldots \ldots \ldots \ldots \ldots \ldots . \ldots \ldots$

8.5 Recommendations ....................... 8-10

9.0 LIST OF CONTRIBUTORS $\ldots \ldots \ldots \ldots \ldots \ldots \ldots \ldots \ldots \ldots \ldots \ldots \ldots$

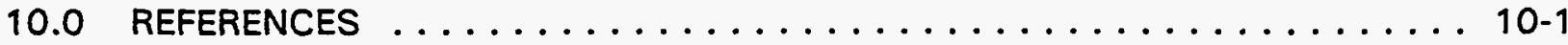




\section{LIST OF FIGURES}

\section{Figure}

Page

2.1 Site location, Durango, Colorado, site . . . . . . . . . . . . . . 2-2

2.2 Generalized geology and borehole locations prior to remediation, Durango, Colorado, site . . . . . . . . . . . . . . . . . . . 2-5

2.3 Surface geology at the mill tailings area, Durango, Colorado, site . . . . . . . 2-6

2.4 Typical cross section, mill tailings area, Durango, Colorado, site . . . . . . . . 2-7

2.5 Ground water elevations in wells, Durango, Colorado, site . . . . . . . . . . . 2-9

2.6 Typical cross section, raffinate ponds area, Durango, Colorado, site ...... 2-11

2.7 April 1990 ground water contour map, raffinate ponds area, Durango, Colorado, site .............................. 2-12

2.8 Land use map, Durango, Colorado, site . . . . . . . . . . . . . . . . . . 2-15

2.9 Locations of ground water wells near Durango, Colorado, site . . . . . . . . 2-19

3.1 Monitor well, surface water, and sediment sampling locations in the mill tailings area and raffinate ponds area, Durango, Colorado, site . . . . . . 3-2

3.2 Locations of monitor wells and piezometers in the mill tailings area, Durango, Colorado, site ......................... 3-3

3.3 Locations of monitor wells in the former raffinate ponds area, Durango, Colorado, site . . . . . . . . . . . . . . . . . . . 3-4

3.4 Sulfate distribution in ground water in November 1983, mill tailings area, Durango, Colorado, site . . . . . . . . . . . . . . . . . 3-23

3.5 Distribution of chloride in ground water, raffinate ponds area, November 1993 and January 1994 data, Durango, Colorado, site . . . . . . 3-25

4.1 Durango conceptual model . . . . . . . . . . . . . . . . 4-3

4.2 Probability distribution of cadmium concentrations, Durango, Colorado, site ................................... 4-9

4.3 Probability distribution of chloride concentrations, Durango, Colorado, site .................................. 4-10

4.4 Probability distribution of manganese concentrations, Durango, Colorado, site .................................. 4-11

4.5 Probability distribution of molybdenum concentrations, Durango, Colorado, site ................................ 4-12

4.6 Probability distribution of selenium concentrations, Durango, Colorado, site ................................. 4-13

4.7 Probability distribution of sodium concentrations, Durango, Colorado, site .................................. 4-14

4.8 Probability distribution of sulfate concentrations, Durango, Colorado, site ................................ 4-15

4.9 Probability distribution of uranium concentrations, Durango, Colorado, site ................................... 4-16

4.10 Probability distribution of vanadium concentrations, Durango, Colorado, site ............................... . 4-17

4.11 Probability distributions for tap water ingestion rates . . . . . . . . . 4-19

4.12 Probability distributions for body weight . . . . . . . . . . . . . 4-20 


\section{LIST OF FIGURES (Continued)}

Eigure

Page

4.13 Probability distribution of sulfate intakes, Durango, Colorado, site

4.14 Probability distribution of cadmium intakes for children, Durango,

Colorado, site . . . . . . . . . . . . . . . . . . . . . . . 4-24

4.15 Probability distribution of chloride intakes for children, Durango,

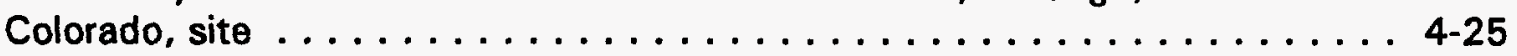

4.16 Probability distribution of manganese intakes for children, Durango,

Colorado, site .............................. 4-26

4.17 Probability distribution of molybdenum intakes for children, Durango,

Colorado, site . . . . . . . . . . . . . . . . . . . . 4-27

4.18 Probability distribution of selenium intakes for children, Durango,

Colorado, site ........................... . 4-28

4.19 Probability distribution of sodium intakes for children, Durango,

Colorado, site . . . . . . . . . . . . . . . . . . . . . . 4-29

4.20 Probability distribution of uranium intakes for children, Durango,

Colorado, site .......................... . 4-30

4.21 Probability distribution of vanadium intakes for children, Durango,

Colorado, site

5.1 Antimony toxicity ranges $\ldots \ldots \ldots \ldots \ldots \ldots \ldots \ldots \ldots \ldots \ldots \ldots \ldots \ldots$

5.2 Arsenic toxicity ranges $\ldots \ldots \ldots \ldots \ldots \ldots \ldots \ldots \ldots \ldots \ldots \ldots \ldots$

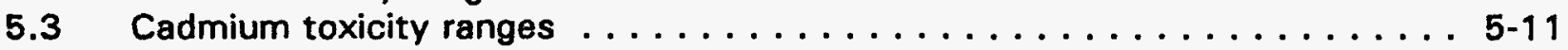

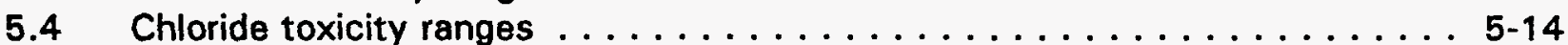

5.5 Lead toxicity ranges . . . . . . . . . . . . . . . . . . . . 5-20

5.6 Manganese toxicity ranges . . . . . . . . . . . . . . . . . . . . 5-24

5.7 Molybdenum toxicity ranges . . . . . . . . . . . . . . . . . . . 5-26

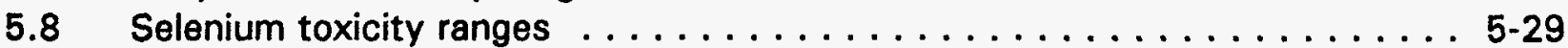

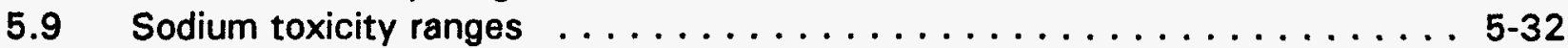

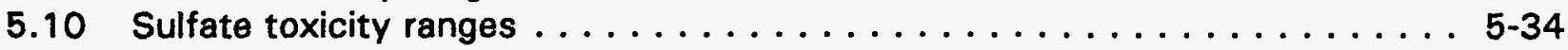

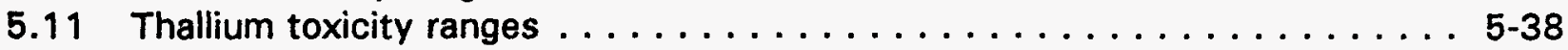

5.12 Half-lives and emissions from decay chain of uranium-238 . . . . . . . 5-39

5.13 Uranium toxicity ranges . . . . . . . . . . . . . . . . . 5 542

5.14 Vanadium toxicity ranges ........................ 5-46

6.1 Health effects of potential sulfate exposure ranges for infants,

Durango, Colorado, site . . . . . . . . . . . . . . . . . . . . 6-2

6.2 Health effects of potential manganese exposure ranges for children,

Durango, Colorado, site . . . . . . . . . . . . . . . . . . . . . 6-4

6.3 Health effects of potential sodium exposure ranges for children,

Durango, Colorado, site . . . . . . . . . . . . . . . . . . . . 6-5

6.4 Health effects of potential chloride exposure ranges for children,

Durango, Colorado, site ... . . . . . . . . . . . . . . . . . 6-6

6.5 Health effects of potential molybdenum exposure ranges for children,

Durango, Colorado, site . . . . . . . . . . . . . . . . . . . 6-7 


\section{LIST OF FIGURES (Continued)}

Figure

Page

6.6 Health effects of potential cadmium exposure ranges for children, Durango, Colorado, site ... . . . . . . . . . . . . . . . . . . 6-11

6.7 Health effects of potential selenium exposure ranges for children,

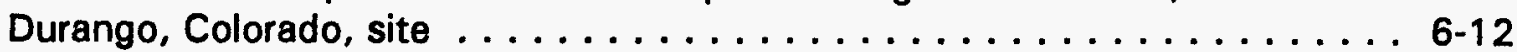

6.8 Health effects of potential vanadium exposure ranges for children, Durango, Colorado, site ........................... 6-13

6.9 Health effects of potential uranium exposure ranges for children, Durango, Colorado, site 


\section{LIST OF TABLES}

Table

Page

2.1 Summary of private wells within a $2-\mathrm{mi}(3-\mathrm{km})$ radius of the Durango, Colorado site

3.1 Monitor wells used to determine water quality and the extent of contamination ................................ 3-5

3.2 Summary of ground water quality data at the mill tailings area at Durango, Colorado, May 1990 - June $1994 \ldots . . \ldots \ldots . . . \ldots$. . . . . 3-7

3.3 Comparison of regional ground water quality data for the Mesaverde

Group to background water quality data from the raffinate ponds area . . . 3-18

3.4 Comparison of the tailings seepage and raffinate to ground water quality in monitor wells DUR-01-612 (October 1990 data) and DUR-02-598 (January 1994 data) . . . . . . . . . . . . . . . . . . . 3-20

3.5 Comparison of geochemical model results of raffinate neutralization and cation exchange to ground water quality in monitor wells DUR-02-625 (1983 data) and DUR-02-598 (1994 data) . . . . . . . . . . 3-21

3.6 Comparison of September 1982 water quality in monitor wells completed in the alluvium, bedrock, and fault, raffinate ponds area, Durango, Colorado, site ......................

3.7 Comparison of November 1993 or January 1994 water quality in monitor wells completed in the alluvium, bedrock, and fault, raffinate ponds area, Durango, Colorado, site . . . . . . . . . . . . . . 3-29

3.8 Summary of ground water quality data at the raffinate ponds area at Durango, Colorado, May 1990 - June $1994 \ldots \ldots \ldots \ldots$. . . . . . . . . . . .

3.9 Contaminants of potential concern for the mill tailings area, Durango, Colorado, site ........................ 3-38

3.10 Contaminants of potential concern for the raffinate ponds area, Durango, Colorado, site ... . . . . . . . . . . . . . . . 3-39

3.11 Predominant stable species of contaminants of potential concern in the ground water system under oxidizing conditions at the mill

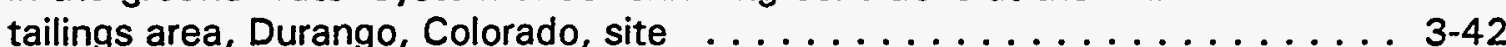

3.12 Predominant stable species of contaminants of potential concern in the ground water system under reducing conditions at the mill tailings area, Durango, Colorado, site

3.13 Predominant stable species of contaminants of potential concern in the ground water system under oxidizing conditions at the raffinate ponds area, Durango, Colorado, site

3.14 Predominant stable species of contaminants of potential concern in the ground water system under reducing conditions at the raffinate ponds area, Durango, Colorado site . . . . . . . . . . . . . . . . 3-45

3.15 Surface water quality data, Durango, Colorado, site . . . . . . . . . 3-50 3.16 Sediment quality data, Durango, Colorado, site . . . . . . . . . . . 3-53 3.17 BOR water quality data from the Animas River, filtered and unfiltered water samples, Durango, Colorado, site . . . . . . . . . . . . . 3-54 


\section{LIST OF TABLES (Concluded)}

Table

3.18 Calculated change in Animas River water quality due to ground water discharge from the mill tailings area, Durango, Colorado, site . . . . . 3-58

3.19 Computed change in Animas River water quality due to ground water discharge from the raffinate ponds area, Durango, Colorado, site . . . . . . 3-61

5.1 Toxicity values: potential carcinogenic effects . . . . . . . . . . . . . . 5-8

5.2 Toxicity values: potential noncarcinogenic effects . . . . . . . . . . . 5-50

6.1 Calculation of hazard quotients for ingestion of ground water, Durango, Colorado, site . . . . . . . . . . . . . . . . . . . . . . 6-8

6.2 Calculation of excess lifetime cancer risks from ingestion of ground water, Durango, Colorado, site . . . . . . . . . . . . . . 6-17

7.1 Comparison of measured concentrations of contaminants of potential concern and modeled surface water quality in the Animas River near the mill tailings area with water quality criteria . . . . . . . . . . 7-6

7.2 Comparison of measured concentrations of contaminants of potential concern and modeled surface water quality in the Animas River near the raffinate ponds area with water quality criteria $\ldots \ldots \ldots \ldots \ldots$. . . . . .

7.3 Comparison of contaminants of potential concern in ground water with available water quality values and phytotoxic concentrations, Durango, Colorado, site . . . . . . . . . . . . . . . . . . . . . 7-12

7.4 Comparison of contaminants of potential concern in sediment from the Animas River with available sediment quality values, Durango, Colorado, site ............................ 7-15

8.1 Concentration limits of constituents for the ground water at the mill tailings area, Durango, Colorado, site .................. 8-5

8.2 Concentration limits of constituents for the ground water at the raffinate ponds area, Durango, Colorado, site . . . . . . . . . . . 8-7 


\section{LIST OF ACRONYMS}

\section{Acronym Definition}

$A C L$

alternate concentration limit

ALAD

BOR

CDPHE

CWA

DHHS

DOE

DW

EPA

ER-L

HEAST

IARC

IRIS

LOAEL aminolevulinic acid dehydratase

Bureau of Reclamation

Colorado Department of Public Health and Environment

Clean Water Act

Department of Health and Human Services

$M C L$

MSL

NA

NCP

ND

NOAA

U.S. Department of Energy

dry weight

U.S. Environmental Protection Agency

effects range-low

Health Effects Assessment Summary Tables

International Agency for Research on Cancer

Integrated Risk Information System

lowest-observed-adverse-effect level

maximum concentration limit

mean sea level

not analyzed; not applicable; not available

National Contingency Plan

not detected; not determined

NOAEL

NR

NS

RDA

RfD

SF

TDS

National Oceanic and Atmospheric Administration

no-observed-adverse-effect level

not relevant

not specified

recommended daily allowance

reference dose

slope factor

total dissolved solids

UMTRA

Uranium Mill Tailings Remedial Action

UMTRCA

USGS

Uranium Mill Tailings Radiation Control Act

WHO

U.S. Geological Survey

World Health Organization 


\subsection{INTRODUCTION}

The purpose of this baseline risk assessment is to determine whether ground water contamination at the Durango, Colorado, uranium mill tailings site could adversely affect human health or the environment. The Durango site is one of 24 designated uranium mill tailings sites undergoing remediation in accordance with the requirements of the Uranium Mill Tailings Radiation Control Act (UMTRCA) (42 USC $\$ 7901$ et seq.) under the oversight of the U.S. Department of Energy (DOE) Uranium Mill Tailings Remedial Action (UMTRA) Project. The remediation of surface contamination at the Durango processing site was completed in May 1991.

This risk assessment is a baseline assessment in the sense that it describes preremediation ground water conditions at the site; ground water contamination was only partially characterized. This document evaluates the potential for public health or environmental risk that may need attention before the site is fully characterized. The risk assessment is based on available ground water data from wells at the processing site. Major exposure pathways have been identified and examined for this risk assessment.

This risk assessment follows the basic framework outlined by the U.S. Environmental Protection Agency (EPA) (EPA, 1989a) for evaluating hazardous waste sites to assess potential health and environmental impacts. The risk assessment framework consists of the following steps:

- Data evaluation.

- Combining existing data from various site investigations.

- Comparing sample results with background and tailings source data.

- Selecting appropriate chemical data for the risk assessment.

- Exposure assessment.

- Characterizing exposure settings.

- Identifying exposure pathways.

- Quantifying exposure.

- Toxicity assessment.

- Identifying toxicity values.

- Evaluating noncarcinogenic effects.

- Evaluating carcinogenic effects from radionuclides and chemical carcinogens.

- Public health risk characterization.

- Comparing toxicity ranges to predicted exposure ranges.

- Combining risks across exposure pathways and multiple contaminants.

- Characterizing uncertainties. 
- Environmental risk.

- Characterizing potential biota exposure pathways.

- Identifying potential ecological receptors.

- Evaluating environmental risk qualitatively.

This framework is incorporated in the methodology developed to evaluate current human health risk at UMTRA Project sites and to estimate risks from potential future use of contaminated ground water or surface water near the former processing site (DOE, 1994).

This risk assessment will support decisions made for the UMTRA Ground Water Project. The DOE was authorized to conduct ground water remediation under the 1988 UMTRCA Amendments Act (42 USC $\$ 7922$ et seq.) and will determine site-specific ground water compliance strategies for each site. This baseline risk assessment provides information to assist in determining the site-specific ground water compliance strategy for the Durango site. 


\subsection{SITE DESCRIPTION}

The former Durango uranium ore processing site consists of two geographically contiguous, but hydrogeologically separate, areas: the mill tailings area and the raffinate ponds area. Both areas are located on the west bank of the Animas River immediately southwest of the intersection of Routes 160 and 550 southwest of the city of Durango, in La Plata County, Colorado (Figure 2.11. Contaminated material from the processing site was relocated from 1986 to 1991 to a disposal site located approximately 1.5 miles (mi) (2.4 kilometers $[\mathrm{km}]$ ) farther to the southwest in a mountain valley near Bodo Canyon.

\section{$2.1 \quad$ SITE BACKGROUND}

A lead smelter, located at the former mill site near the south end of the mill tailings area, operated from 1880 to 1930 . Slag from the smelter operation was dumped at the southeast corner of the area along the edge of the Animas River.

The mill was constructed in 1941 to produce vanadium; uranium production began in 1943. The mill was operated on the same site until 1963. It processed approximately 1.6 million tons (1.4 million tonnes) of ore averaging 0.29 percent uranium oxide and 1.60 percent vanadium oxide. The ore was delivered to the mill from various mines in the Uravan mineral belt.

The milling process involved two separate stages. In the first stage, ores were roasted with sodium chloride, then treated with a sodium carbonate solution to produce an alkaline solution containing both uranium and vanadium. This solution was filtered to separate the solution from the tailings, then treated to remove uranium and vanadium. The filtrate (alkaline-leach tailings) was washed with water and stored for use in the second stage of processing. Precipitation of uranium and vanadium from the alkaline-leach solution was carried out by adjusting the $\mathrm{pH}$ and the oxidation-reduction potential using an acid (sulfuric or hydrochloric acid), a base (sodium hydroxide), and an oxidant (sodium chlorate). The uranium was recovered as uranium dioxide and soluble vanadium was recycled through the process and precipitated as red cake (Tame et al., 1961; Merritt, 1971).

The second stage of processing used the tailings from the first stage. The tailings were leached using an acid solution containing both hydrochloric and sulfuric acids. The leachate was then separated from the acid-leach tailings and oxidized using potassium permanganate, and the $\mathrm{pH}$ was adjusted by adding sodium carbonate. Uranium and vanadium were removed from this solution by solvent extraction using an immiscible organic solvent consisting primarily of tertiary amines, di-2 (ethylhexyl) phosphoric acid, heptadecyl phosphoric acid, and primary decyl alcohol, dissolved in kerosene (Merritt, 1971). After the uranium and vanadium were removed from the aqueous solution, the spent solution (raffinate) was disposed of. Uranium and vanadium were stripped and precipitated from the organic solvent using a sodium carbonate solution (Tame 


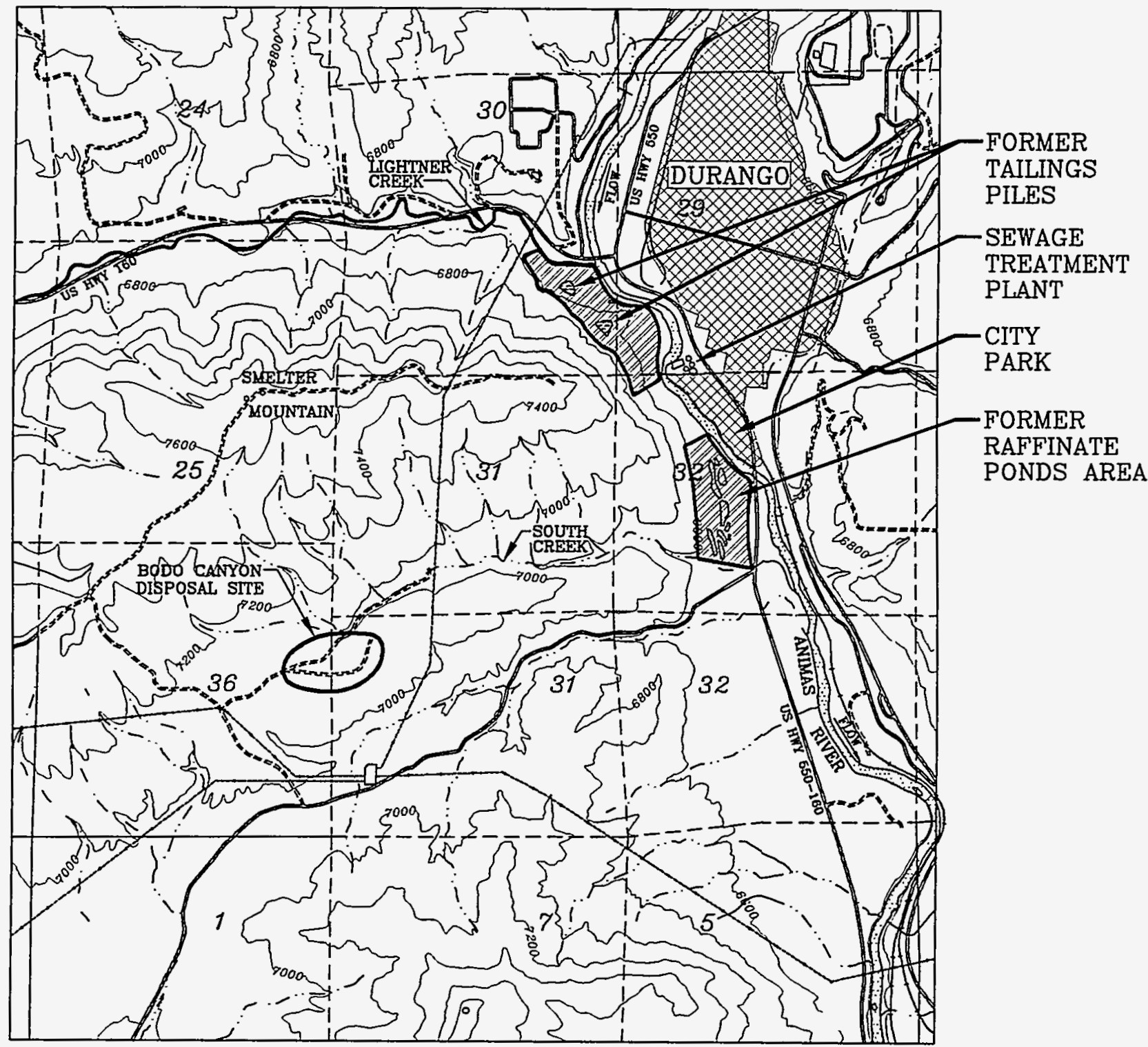

BASE MAP REFERENCE: USGS 7.5 MIN TOPO QUAD MAPS FOR "DURANGO WEST" AND DURANGO EAST" QUADS DATED 1963; AND "BASIN MOUNTAIN" AND "LONA LINDA" QUADS DATED 1868; AISO CITY OF DURANGO ZONING MAP DATED 1999,

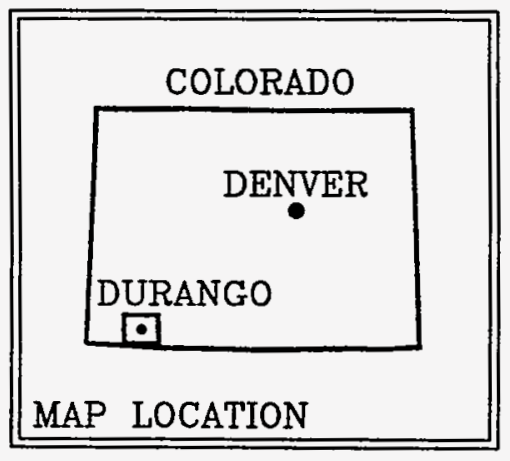

BASE MAP REFERENCE:

USGS 7.5 MIN TOPO QUAD MAPS

FOR "DURANGO HEST" AND "DURANGO

EAST" QUADS DATED 1963; AND

BASIN MOUNTAIN AND "LOMA LINDA"

QUADS, DATED 1988; ALSO CITY OF

DURANGO ZONING MAP, 1983.
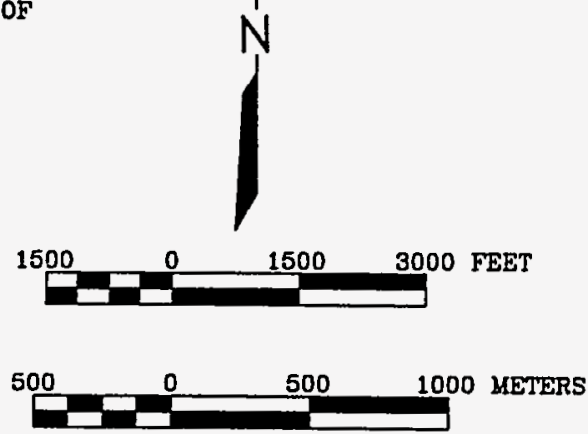

FIGURE 2.1

SITE LOCATION, DURANGO, COLORADO, SITE 
et al. 1961$)$. Thus, processing waste solutions and tailings contained sulfate $\left(\mathrm{SO}_{4}{ }^{-}\right)$, sodium $\left(\mathrm{Na}^{+}\right)$, chloride $\left(\mathrm{Cl}^{-}\right)$, potassium $\left(\mathrm{K}^{+}\right)$, and manganese $\left(\mathrm{Mn}^{2+}\right)$ derived from processing reagents.

Before 1959, all waste solutions and acid-leach tailings were discharged to the Animas River (Tsivoglou et al., 1960). Beginning in 1959, overflow water from the stored carbonate leach tailings and slurried acid-leach tailings were mixed in a settling pond atop the former large tailings pile adjacent to the mill. Overflow from this pond was treated with barium sulfate and a flocculent and settled in a second pond atop the former small tailings pile at the mill tailings area. Overflow from this pond was discharged to the Animas River at a rate of about 97 gallons (gal) (370 liters [L]) per minute (Tsivoglou et al., 1960). Spent alkaline-leach solutions from the first stage of uranium-vanadium recovery were discharged directly to the Animas River at a rate of about $256 \mathrm{gal}$ (969 L) per minute (Tsivoglou et al., 1960).

Raffinates from the second stage of processing contained most of the radioactivity. This waste solution was pumped to a tank above the mill and, from there, discharged into a 3000-foot (ft) (900-meter [m]) long ditch that carried the waste to the raffinate ponds area. An additional $3000 \mathrm{ft}(900 \mathrm{~m})$ of ditch carried the raffinate through a series of ponds on the terraced slope of the raffinate ponds area. The raffinate evaporated and percolated into the underlying alluvium, colluvium, and bedrock. Raffinates were discharged into the ditch between the mill and the ponds at a rate of about $50 \mathrm{gal}(190 \mathrm{~L})$ per minute. However, only about 40 gal $(150 \mathrm{~L})$ per minute reached the ponds due to seepage losses within the $6000 \mathrm{ft}(2000 \mathrm{~m})$ of ditch (Tsivoglou et al., 1960). Using a value of $50 \mathrm{gal}(190 \mathrm{~L})$ per minute of continuous discharge over 3 years, it is estimated that nearly 82 million gal ( 310 million $L$ ) of raffinate were discharged to the ditch and pond system.

The DOE began relocating the tailing piles, mill debris, and contaminated soils from the mill tailings area and raffinate ponds area to the Bodo Canyon disposal site in November 1986; remedial action was completed in May 1991. A total of 2.5 million cubic yards $\left(\mathrm{yd}^{3}\right)$ (1.9 million cubic meters $\left.\left[\mathrm{m}^{3}\right]\right)$ of contaminated materials were relocated to the Bodo Canyon disposal cell. The mill tailings area and the raffinate ponds area were contoured and planted with grasses after the tailing piles and contaminated soils were removed.

\subsection{CLIMATE}

The semiarid climate of the Durango area is characterized by severe winters and moderate summers. The annual mean temperature is $\mathbf{5 0}$ degrees Fahrenheit $\left({ }^{\circ} \mathrm{F}\right)\left(10\right.$ degrees centigrade $\left.\left[{ }^{\circ} \mathrm{C}\right]\right)$, with monthly averages varying from $19^{\circ} \mathrm{F}$ $\left(-7^{\circ} \mathrm{C}\right)$ in January to $70^{\circ} \mathrm{F}\left(21^{\circ} \mathrm{C}\right)$ in July. Precipitation is predominantly from heavy rainstorms (May through October) and winter snowfall. Precipitation averages approximately 19 inches (48 centimeters [cm]) per year. Annual potential evapotranspiration exceeds precipitation by about 30 inches $(76 \mathrm{~cm})$. However, during December, January, and February, precipitation is twice the 
potential evapotranspiration, resulting in ample moisture available for infiltration (Tsivoglou et al., 1960). The prevailing wind direction is west-northwest down the river valley. The average annual wind speed was $6.6 \mathrm{mi}(11 \mathrm{~km})$ per hour in 1982 (DOE, 1985)

\subsection{PHYSIOGRAPHIC SETTING}

The mill tailings area encompasses approximately 40 acres (ac) (16 hectares [ha]). It is located on a bedrock-supported river terrace between Smelter Mountain to the west, the Animas River to the east, and Lightner Creek to the north (Figure 2.2).

The raffinate ponds area occupies approximately 20 ac ( $8 \mathrm{ha})$ on another river terrace approximately $1500 \mathrm{ft}(500 \mathrm{~m})$ south of the mill tailings area along the west bank of the Animas River. A narrow terrace above the Animas River connects the two areas.

Lightner Creek flows along the north edge of the mill tailings area. The Animas River flows along the eastern sides of the mill tailings and raffinate ponds area. A small, intermittent creek (called South Creek in this study) forms the southern boundary of the raffinate ponds area.

The topography of the processing site was modified during the removal of the tailings and contaminated soils. The property slopes steeply down from Smelter Mountain but becomes relatively level near Lightner Creek and the Animas River.

\subsection{HYDROGEOLOGY}

\subsubsection{Mill tailings area}

The mill tailings area is underlain by more than $1700 \mathrm{ft}(500 \mathrm{~m})$ of dark gray to black Mancos Shale. The Mancos Shale is truncated by the Smelter Mountain fault south of the mill tailings area. The present topography at the mill tailings area is shown in Figure 2.3.

Along the base of Smelter Mountain, the Mancos Shale is directly overlain by up to $25 \mathrm{ft}(9 \mathrm{~m})$ of colluvium. The colluvium consists of poorly sorted, silty soil from Smelter Mountain.

Closer to Lightner Creek and the Animas River, up to $15 \mathrm{ft}(5 \mathrm{~m})$ of river-laid sand and gravel occur over the bedrock and under the colluvium (Figure 2.4). These well-sorted, permeable sands and gravels may represent glacial outwash and/or alluvial river gravels. As much as $25 \mathrm{ft}(7.6 \mathrm{~m})$ of the vitreous lead smelter slag remains along the bank of the Animas River near the southeast corner of the mill tailings area. 


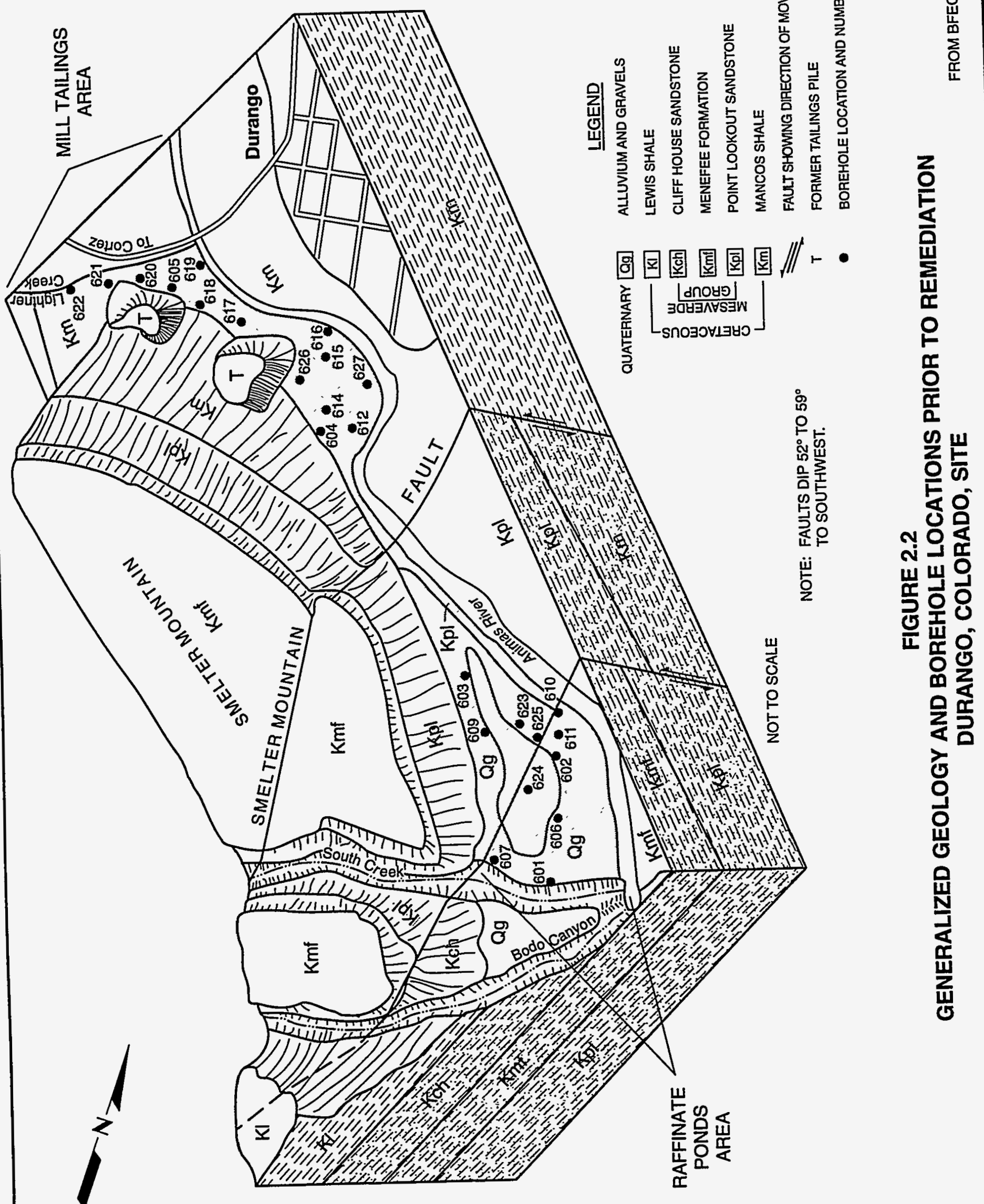




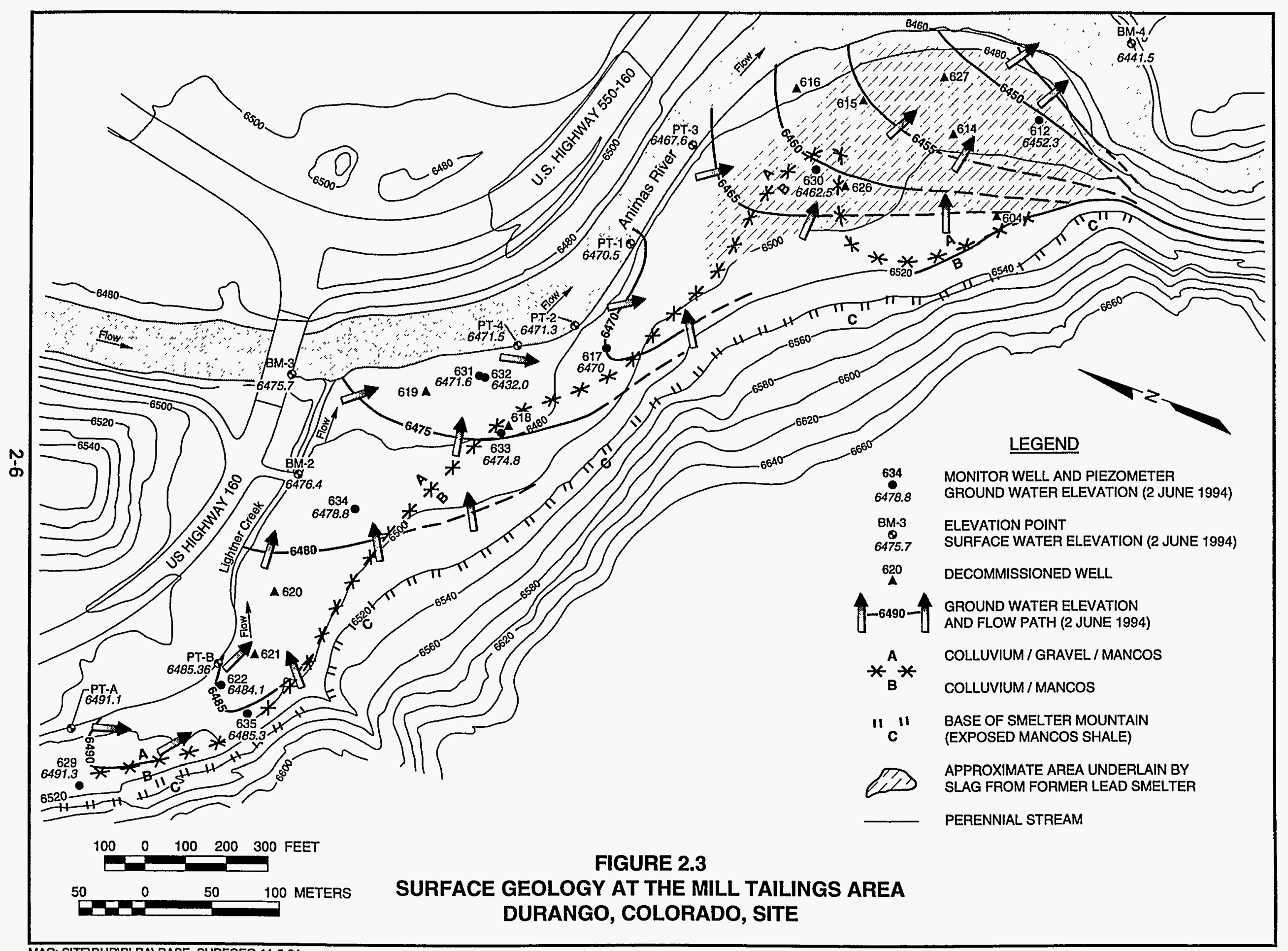

MAC: SITEDURIBLRAIBASE-SURFGEO 11-5-94 


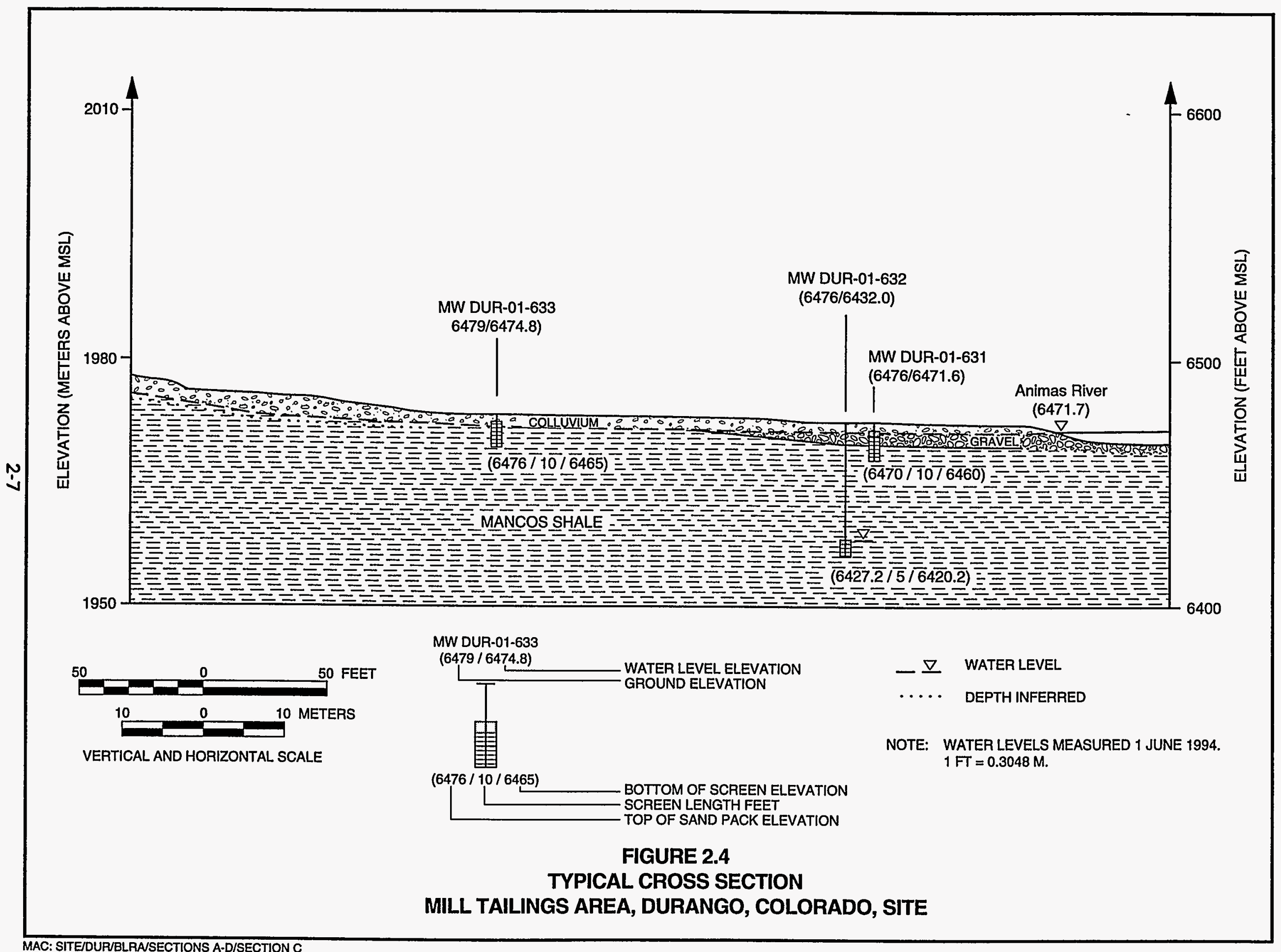


Ground water in the colluvium near the base of Smelter Mountain is recharged primarily by runoff from the mountain and by infiltrating precipitation. The drainage basin upslope of the mill tailings area is small because of a steep cliff along the east side of Smelter Mountain. Therefore, the amount of recharge from this area is relatively small.

Nearer Lightner Creek and the Animas River, sand and gravel deposits receive recharge from both streams. During spring runoff when the river stage is high, water flows into the aquifer. When the river stage is lower, the ground water flows from the aquifer back into the Animas River. The ground water flow pattern on 2 June 1994 is shown on Figure 2.3. Some of the ground water may flow down through the colluvium into the underlying Mancos Shale.

Ultimately, water from the site that moves through the shale discharges to the Animas River. Because the permeability of the Mancos Shale is very low, only a small quantity of water passes by this route to the river as compared to the route through the more permeable colluvium.

The high topographic relief and high ground water elevations in wells on the east side of the Animas River (Figure 2.5) indicate that ground water on the east side flows toward and discharges into the Animas River. This flow pattern will prevent migration of ground water from one side of the river to the other.

Slug-removal aquifer tests were conducted in monitor wells DUR-01-612, -615 , $-616,-619$, and -621 (Figure 2.2) before the tailings piles and contaminated soils were removed (BFEC, 1983). These wells were screened predominantly in the gravels above the bedrock. The hydraulic conductivity calculated from four of these tests is approximately 20 feet per day ( $\mathrm{ft} / \mathrm{day})\left(7 \times 10^{-3}\right.$ centimeters per second [cm/s]), although the tests in well DUR-01-621 in the terrace gravels near Lightner Creek indicate a hydraulic conductivity of approximately $300 \mathrm{ft} /$ day $\left(1 \times 10^{-1} \mathrm{~cm} / \mathrm{s}\right)$.

Qualitative aquifer pumping tests were conducted during the summer of 1994 in monitor wells DUR-01-612 and -617 and in piezometers DUR-01-630, -631 , and -633 (see Figure 2.3) (TAC, 1995). These tests demonstrate that the part of the site underlain by colluvium over the Mancos Shale has only limited ability to yield water to wells (piezometers DUR-01-630 and -633 in Figure 2.3). By contrast, the sand and gravel deposits encountered in wells DUR-01-612 and -617 and in piezometer DUR-01-631 can yield significant amounts of water and will have a good sustainable yield because of recharge from Lightner Creek and the Animas River.

The bedrock has minimal ground water yield. Piezometer DUR-01-632 is screened from 39 to $46 \mathrm{ft}(14$ to $16 \mathrm{~m})$ below the top of the Mancos Shale and at approximately the same depth below the river level (see Figure 2.4).

Ground water can be seen seeping from the Smelter Mountain fault south of, and at a higher elevation than, the mill tailings area. This fault forms a hydrologic barrier between the mill tailings and the raffinate ponds areas. 


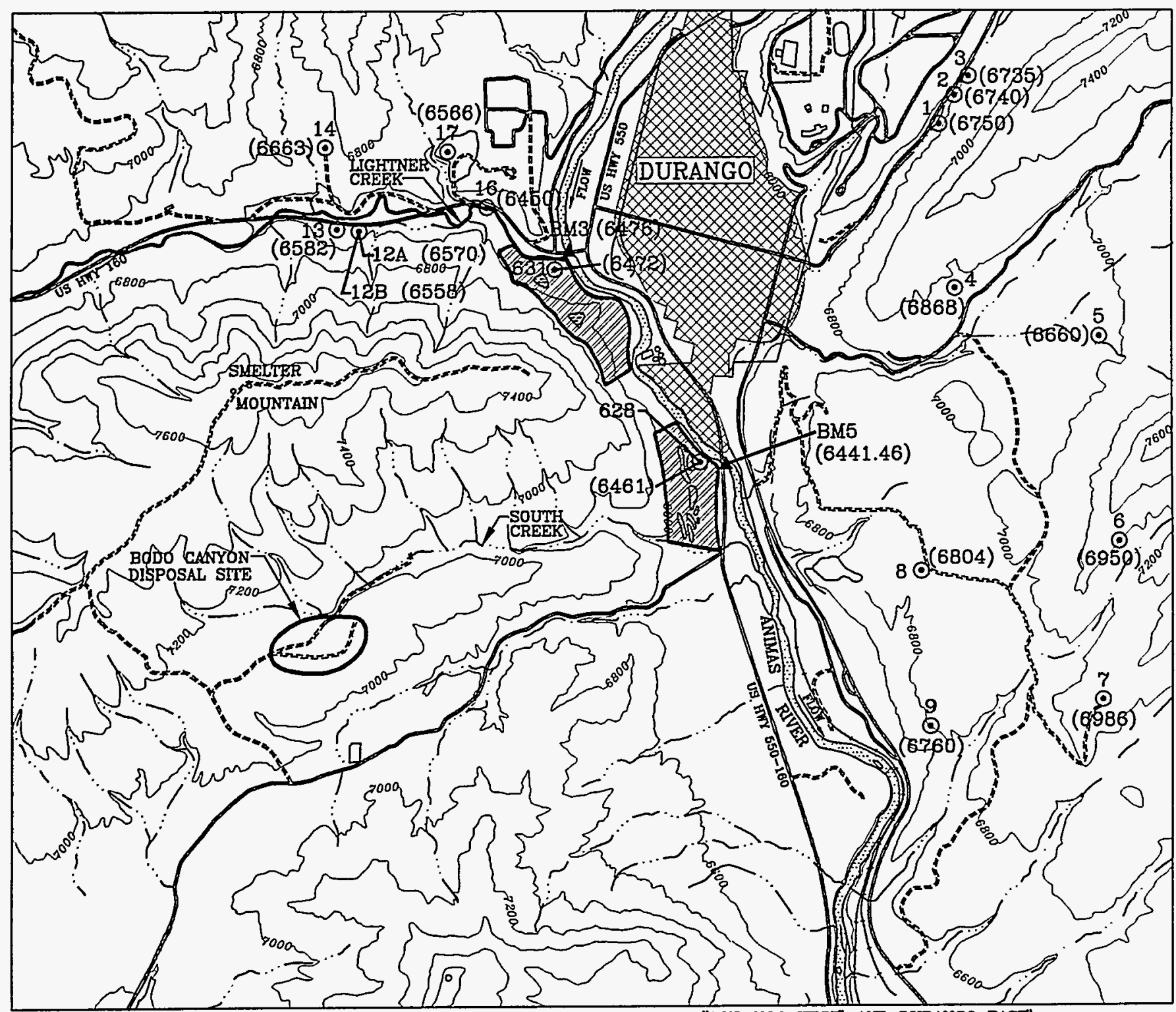

BASE MAP REFERENCE: USGS 7.5 MIN TOPO QUAD MAPS FOR "DURANGO HEST" AND DURANGO EAST" QUADS DATED 1963; AND "BASIN MOUNTAIN" AND "LOMA LINDA" QUADS DATED 1968; AISO CITY OF DURANGO ZONING MAP DATED 1993.

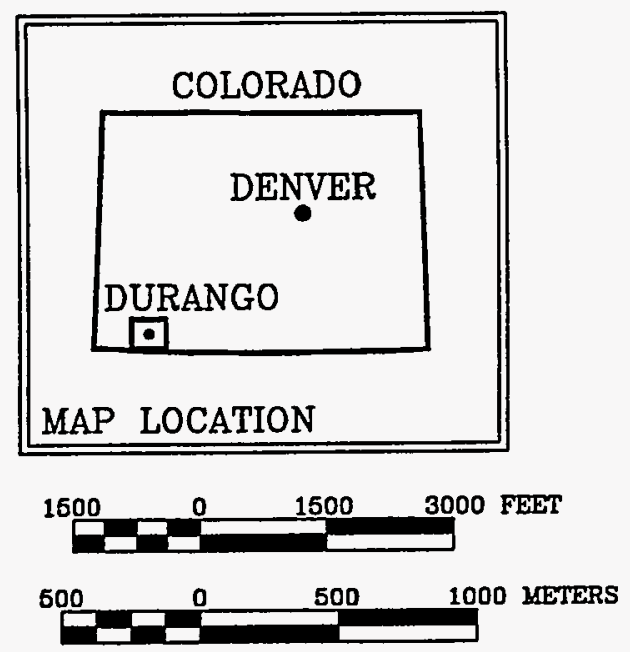

\section{LEGEND}

1 GROUND WATER WELL LOCATION -

(6750) GROUND WATER ELEVATION (FEET) **

BM3 ELEVATHON OF ANLMAS RIVER

(6476)

UUTRA SITE

* LOCATION ESTMATED FROM INFORMATION ON HELI LOGS AND INTERVIEHS FITH OHNERS OR OTHERS IN DURANGO.

* HATER lEVEL mLEVATION CALCULATED FrOM DEPTH TO HATER REPORTED ON FELI IOG (DOE, 1995). GROUND FIEVATION INTERPOLATED FROM USGS TOPOGRAPHIC LAP.

NOTE: $1 \mathrm{FT}=0.3048 \mathrm{M}$.

FIGURE 2.5

\section{GROUND WATER ELEVATIONS IN WELLS}

DURANGO, COLORADO, STTE 


\subsubsection{Raffinate ponds area}

Two bedrock units, both members of the Mesaverde Group, underlie the raffinate ponds area (BOR, 1990). The Point Lookout Sandstone underlies the northwestern two-thirds of the area between the Smelter Mountain fault and another fault that cuts through the raffinate ponds area (see Figure 2.2). The Menefee Formation underlies the southeastern one-third of the area southeast of the fault that cuts across the raffinate ponds area. This fault is a northeastsouthwest trending high angle that dips to the southeast at approximately 55 degrees.

The Point Lookout Sandstone consists of siltstone with interbedded sandstone and minor amounts of shale (BOR, 1990). The Menefee Formation consists of massive sandstone and shale, with beds of carbonaceous shale and coal. The fault contains up to $1 \mathrm{ft}(0.3 \mathrm{~m})$ of clayey gouge.

Before site remediation, unconsolidated surficial deposits in the raffinate ponds area consisted of colluvium from the slope of Smelter Mountain, glacial outwash, and recent river alluvium (BOR, 1990). The surficial deposits were 20 to $30 \mathrm{ft}(6$ to $10 \mathrm{~m})$ thick in the area of the ponds (Figure 2.6). As much as 20 $\mathrm{ft}(6 \mathrm{~m})$ of surficial deposits were removed during site remediation. Most of the remaining surficial material was mixed during remediation activities and now is a mixture of clayey sands, gravels, and cobbles. Some gravel beds overlying the bedrock remain.

Ground water below the raffinate ponds area is recharged by infiltration of precipitation and by ground water moving through the bedrock from the west. The elevations of both the alluvium/bedrock interface and the ground water are higher than the water level in the Animas River. Therefore, unlike the mill tailings area, the river does not recharge the aquifer in this area.

The water table in the eastern part of the raffinate ponds area is above the alluvium/bedrock interface. Farther to the west, all the ground water is within the bedrock and the alluvium is unsaturated. Ground water flow in the Point Lookout Sandstone and Menefee Formation is mostly through open bedding planes and joints (BOR, 1990). Ground water also flows through the fault cutting the bedrock (BFEC, 1983).

It is likely that surface water flowing down South Creek during wet times may infiltrate the surficial deposits and recharge the ground water, as evidenced by the large fluctuations of the ground water levels in monitor well DUR-02-607. Infiltration from South Creek also recharges the fault near monitor well DUR-02-607 (see Figure 2.2).

Ground water flows toward and discharges into the Animas River with an average gradient of approximately 3 percent. An April 1990 ground water contour map is shown in Figure 2.7. 


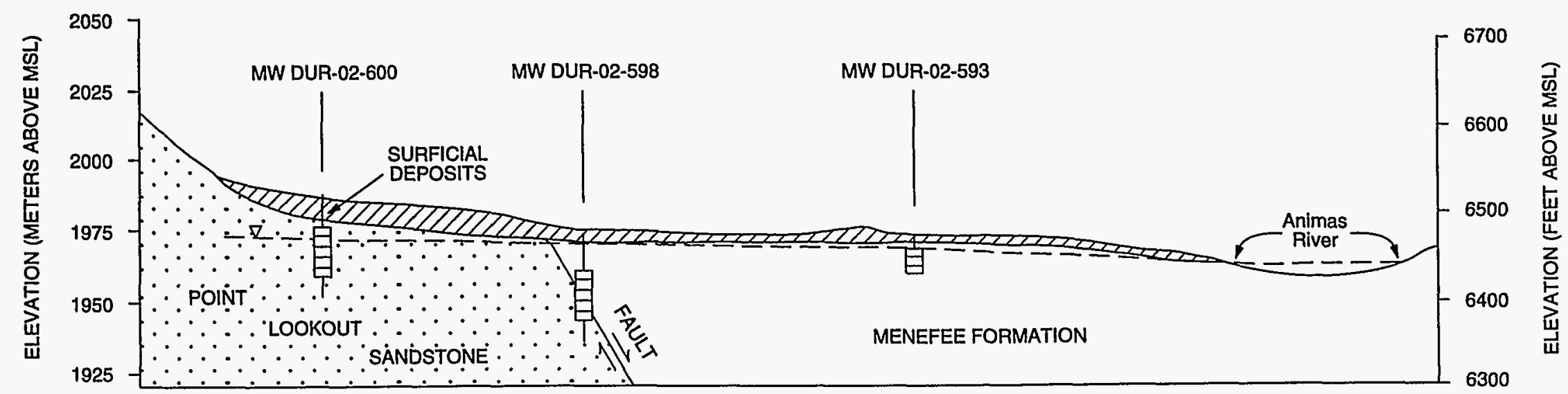

VERTICAL AND HORIZONTAL SCALE

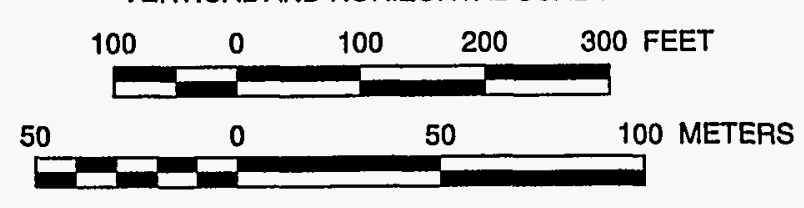

\section{LEGEND}

MW DUR-02-593

$\left\{\begin{array}{l}\text { MONITOR WELLL } \\ \text { 日 J SAND PACK } \\ \text { INTERVAL }\end{array}\right.$

FIGURE 2.6

TYPICAL CROSS SECTION, RAFFINATE PONDS AREA,

DURANGO, COLORADO, SITE 


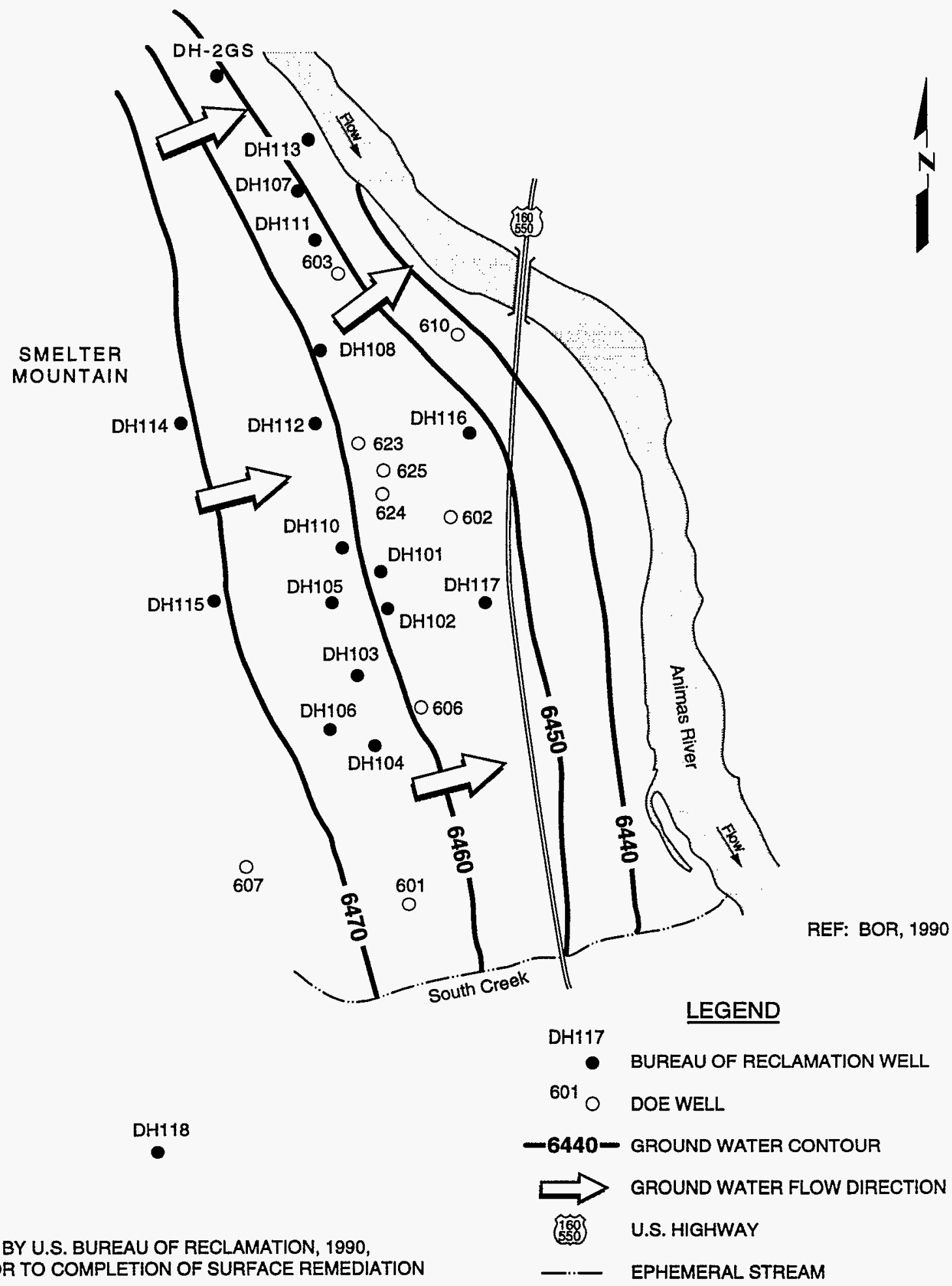

PRIOR TO COMPLETION OF SURFACE REMEDIATION

200

$200 \quad 400$ 600

APPROXIMATE SCALE IN FEET

$\begin{array}{lllll}50 & 0 & 50 & 100 & 150\end{array}$

APPROXIMATE SCALE IN METERS

FIGURE 2.7

APRIL 1990 GROUND WATER CONTOUR MAP

RAFFINATE PONDS AREA, DURANGO, COLORADO, SITE 
Hydraulic conductivity tests resulted in computed average hydraulic conductivities of $22 \mathrm{ft} /$ day $\left(8 \times 10^{-3} \mathrm{~cm} / \mathrm{s}\right)$ in the alluvium (DOE, 1991), $0.2 \mathrm{ft} /$ day $\left(8 \times 10^{-5} \mathrm{~cm} / \mathrm{s}\right)$ in both the Menefee Formation and Point Lookout Sandstone, and $0.8 \mathrm{ft} /$ day $\left(3 \times 10^{-4} \mathrm{~cm} / \mathrm{s}\right)$ in the fault (BOR, 1990). These permeabilities indicate that wells could produce more than $150 \mathrm{gal}(570 \mathrm{~L})$ per day. The yield will be sustained if pumping wells create a sufficient cone of depression to induce recharge from the Animas River.

Based on the gradient calculated from the ground water contours (0.03), an assumed porosity of 15 percent (Freeze and Cherry, 1979), and the measured hydraulic conductivities of the Menefee Formation and Point Lookout Sandstone, the ground water in the bedrock is estimated to move at a rate of approximately $15 \mathrm{ft}(5 \mathrm{~m})$ per year. It will move approximately $45 \mathrm{ft}(14 \mathrm{~m})$ per year in the fault, assuming a gradient of 0.021 along the fault calculated from water levels in wells completed within the fault (wells DUR-02-592 and -598). Ground water in the alluvium during wet times could move approximately $800 \mathrm{ft}(240$ $\mathrm{m})$ per year if the bedrock surface has approximately the same slope as the ground water gradient and the porosity is approximately 30 percent.

As with the mill tailings area, the high topographic relief and high ground water elevations (Figure 2.5) demonstrate that ground water on the opposite side of the river also flows toward and discharges to the Animas River. This flow pattern will prevent migration of ground water from one side of the river to the other. Ground water may move down into the fault and the bedrock. Regional hydrogeologic information suggests that the rate and volume of ground water movement in the bedrock are minimal.

\subsection{SURFACE WATER}

The Durango site is bordered by three surface water features: Lightner Creek to the north, the Animas River to the east, and an unnamed ephemeral stream (called South Creek in this document) to the south. Lightner Creek is a perennial stream that flows from west to east along the northern boundary of the site. Between 1927 and 1949, it had a mean annual flow of 22.6 cubic feet per second $\left(\mathrm{ft}^{3} / \mathrm{s}\right)\left(0.68\right.$ cubic meter per second $\left.\left[\mathrm{m}^{3} / \mathrm{s}\right]\right)$, and a low daily flow of $1.0 \mathrm{ft}^{3} / \mathrm{s}\left(0.03 \mathrm{~m}^{3} / \mathrm{s}\right)$ or less (USGS, 1993). Lightner Creek has a total stream length of about $15 \mathrm{mi}(24 \mathrm{~km})$ (DOE, 1985).

The Animas River forms the eastern and southern boundaries of the mill tailings area and borders the eastern edge of the northern part of the raffinate ponds area. A U.S. Geological Survey (USGS) gauging station is maintained approximately $4500 \mathrm{ft}(1500 \mathrm{~m})$ upstream of the confluence of the Animas River and Lightner Creek. Upstream of the former processing site, the Animas River has a drainage area of approximately 770 square miles $\left(\mathrm{mi}^{2}\right)(2000$ square kilometers $\left[\mathrm{km}^{2}\right]$ ) (including that of Lightner Creek), and a length of $62 \mathrm{mi}$ $(100 \mathrm{~km})$. The mean annual flow in the river past the Durango site between 1898 and 1992 was $812 \mathrm{ft}^{3} / \mathrm{s}\left(24 \mathrm{~m}^{3} / \mathrm{s}\right.$ ) (USGS, 1993). The record 7-day low 
flow was $100 \mathrm{ft}^{3} / \mathrm{s}\left(3 \mathrm{~m}^{3} / \mathrm{s}\right)$ in December 1917. Sections of both Lightner Creek and Animas River are incised into bedrock.

South Creek along the southern edge of the raffinate ponds area is the lower end of the arroyo along the north side of the Bodo Canyon disposal site. This creek is mostly dry, except during wet times of year and when treated water is released from the toe drain collection pond at the disposal cell. During the dry periods, standing water remains in isolated depressions in the bedrock. Water from South Creek could seep down into the bedrock and fault beneath the raffinate ponds area. South Creek joins the Animas River approximately $600 \mathrm{ft}$ $(200 \mathrm{~m})$ east of the southeast corner of the raffinate ponds area.

\subsection{LAND USE}

The primary landowner in the region is the federal government, which controls the San Juan National Forest to the north of Durango and holds in trust large Indian reservation lands to the south and west of Durango (about 57 percent of the land in La Plata County) (DOE, 1983; DOE, 1985). Privately owned lands are second in extent (about 41 percent), followed by state, county, and municipal lands (about 2 percent combined). The Durango site is owned by the state of Colorado. Lands in the immediate vicinity of the site are owned by the city of Durango, the Colorado Department of Natural Resources, and private interests. A land use map for the area surrounding the site is provided in Figure 2.8. Land use in the vicinity of the Durango site is primarily commercial, residential (in the city of Durango), and open space. The city operates a nearby sewage treatment plant and a city park on the east side of the Animas River. The Department of Natural Resources controls the Bodo Canyon Wildlife Area.

Land in downtown Durango, northeast of the site, has been developed since the late 1800s (DOE, 1983; DOE, 1985). The major land use changes near the site have occurred in the Animas River valley. This land has been converted to urban uses with construction of the sewage treatment plant across the Animas River south of the site and construction of a commercial center southeast of the site (Figure 2.8). Land use within the Bodo Canyon Wildlife Area west and southwest of the site changed from livestock grazing to resource conservation and recreation in the early 1970 s.

Other prominent uses include transportation (U.S. Highways 160 and 550 and the Durango-Silverton railroad yard), utility (Durango sewage treatment plant), and industrial (Bodo Industrial Park). The Durango site lies outside the city limits, about $0.25 \mathrm{mi}(0.4 \mathrm{~km})$ from the central business district of Durango. To the north and northwest of the site (across Highway 160) are residential and commercial/industrial properties. Smelter Mountain is on the western boundary of the site, and the Animas River is on the eastern boundary. To the east, across the Animas River and within Durango city limits, are public lands and, farther east, residential and commercial/industrial properties. A riverside park is across the river adjacent to the sewage treatment plant. To the southeast are additional residential and commercial properties. 


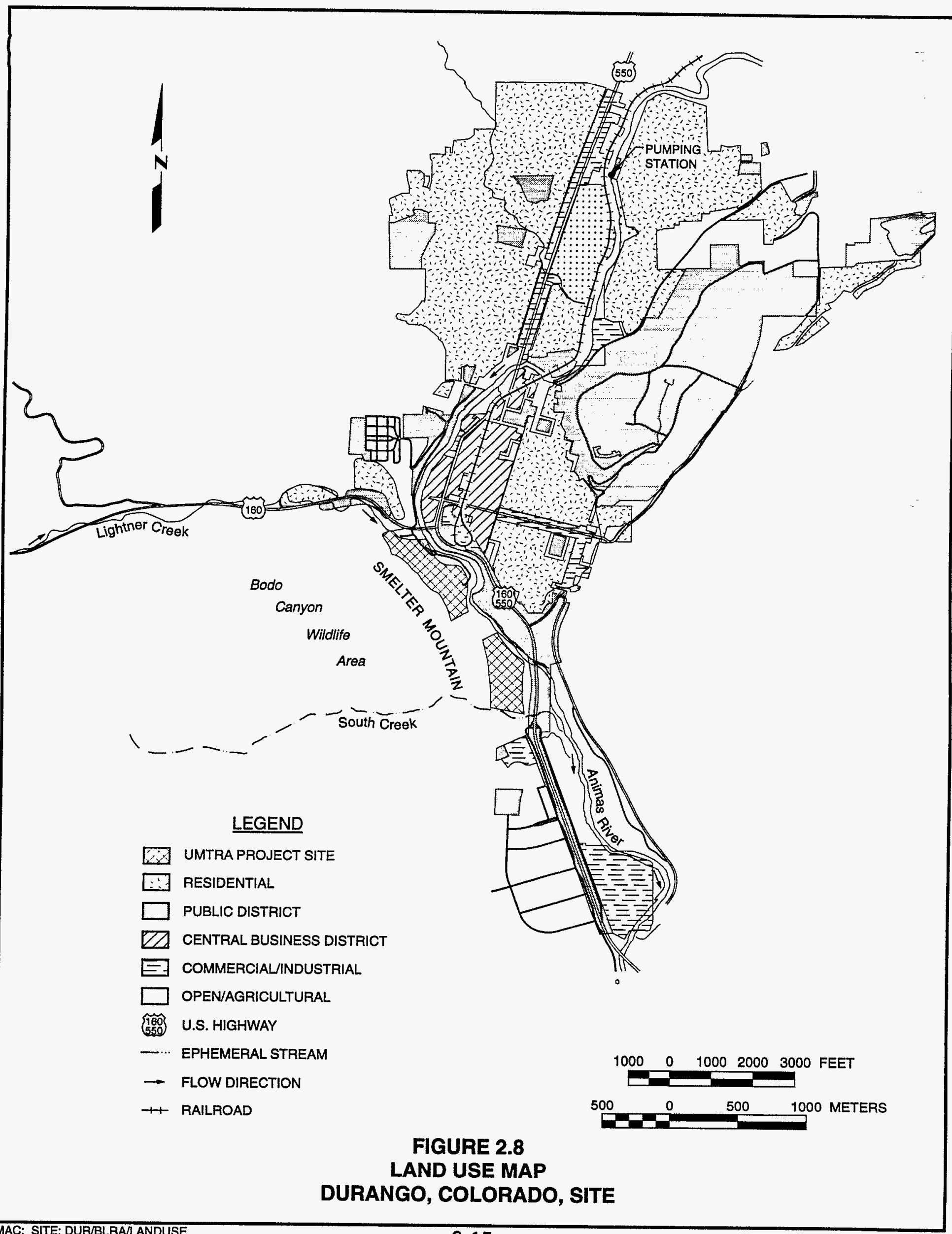


Potential development plans for the former mill tailings area at the site include construction of a visitors' center, parking lots, and a museum or other type of public building (Hoch, 1994). As part of the Animas-La Plata water project, there are draft plans to construct a pumping plant in the former raffinate ponds area of the site. This federal project would supply irrigation water to farmland; drinking water to Durango, Farmington, and Aztec; and water to the Southern Ute and Ute Mountain tribes (Hageman, 1994). Development of additional water resources is a concern because the city's water supply is not sufficient to meet future needs. However, there is public opposition to the project (Hageman, 1994). There are no plans to develop either portion of the site for residential use (Hoch, 1994).

\subsection{WATER USE}

Approximately 13,000 people live within the Durango city limits (TAC, 1994a). There are no known wells in use within the city limits. Development and utility policies for the city of Durango prohibit the drilling of private wells within city limits. However, wells can be drilled on county lands (Hoch, 1994).

The water supply system for the city of Durango is the largest in the county, not only servicing city residents but also selling water to neighboring water districts and companies serving the surrounding developed areas. The city's primary water source is the Florida River, with additional water taken from the Animas River during periods of high demand (generally during the summer). The water pumping station from the Animas River is approximately $2 \mathrm{mi}(3 \mathrm{~km})$ upstream from the northern boundary of the former mill tailings area (Figure 2.8).

The system services approximately 17,000 people, with approximately 3400 residential customers and 1100 commercial customers. Its service area extends $2 \mathrm{mi}(3 \mathrm{~km})$ to the west and south and $10 \mathrm{mi}(16 \mathrm{~km})$ to the north from the city boundaries (Rogers, 1994).

A survey of water use in the area surrounding the Durango site was conducted using information from the Colorado Division of Water Resources database and field investigations (TAC, 1994a). Although the city is considering developing additional water resources to supplement the existing water supply, ground water has not been considered as a water source for the municipal water supply system (Rogers, 1994). Ground water in the area is considered of poor quality with high hardness, iron, and manganese levels (Rogers, 1994).

Table 2.1 summarizes the information obtained for domestic and commercial wells within a 2-mi $(3-\mathrm{km}$ ) radius of the site (Figure 2.9). Some of the listed wells are in use; however, the status of several listed wells is unknown because of difficulty in determining the current property owners.

The nearest known downgradient well is across U.S. Highway 550, approximately $0.2 \mathrm{mi}(0.3 \mathrm{~km}$ ) southeast of the site (number 10 in Figure 2.9 


\begin{tabular}{|c|c|c|c|c|c|c|c|c|}
\hline & 1 & 1962 & 7 & $\begin{array}{c}40 \\
(30-40 \text { perf. })^{b}\end{array}$ & 30 & Unknown & NA & Domestic \\
\hline & 2 & 1958 & 30 & 38 & 10 & Unknown & NA & Domestic \\
\hline & 4 & 1961 & 3 & $\begin{array}{c}100 \\
(60-90 \text { perf. })\end{array}$ & 32 & $\begin{array}{l}\text { Shale and slide } \\
\text { rock or } \\
\text { sandstone }\end{array}$ & NA & Domestic \\
\hline & 5 & 1977 & 4.5 & 351 & 290 & Unknown & NA & Domestic \\
\hline & 6 & 1972 & 6 & 500 & 250 & Unknown & In use & Domestic \\
\hline & 8 & 1991 & 35 & $\begin{array}{c}155 \\
(125-155 \text { perf. })\end{array}$ & 96 & $\begin{array}{c}\text { Cemented } \\
\text { gravel }\end{array}$ & In use & $\begin{array}{l}\text { Domestic, commercial, } \\
\text { irrigation; very little } \\
\text { drawdown }\end{array}$ \\
\hline & 9 & 1986 & $6-8$ & $\begin{array}{c}105 \\
(75-105 \text { perf. })\end{array}$ & 60 & Shale & In use & $\begin{array}{l}\text { Commercial, domestic, } \\
\text { irrigation, stock, fish } \\
\text { ponds }\end{array}$ \\
\hline & 10 & 1963 & Unknown & 160 & Unknown & Unknown & $\begin{array}{l}\text { Never } \\
\text { used }\end{array}$ & Unusable water \\
\hline 窟变 & 11 & 1967 & 8 & 101 & 90 & Shale & NA & $\begin{array}{l}\text { Domestic/approximate } \\
\text { location }\end{array}$ \\
\hline
\end{tabular}




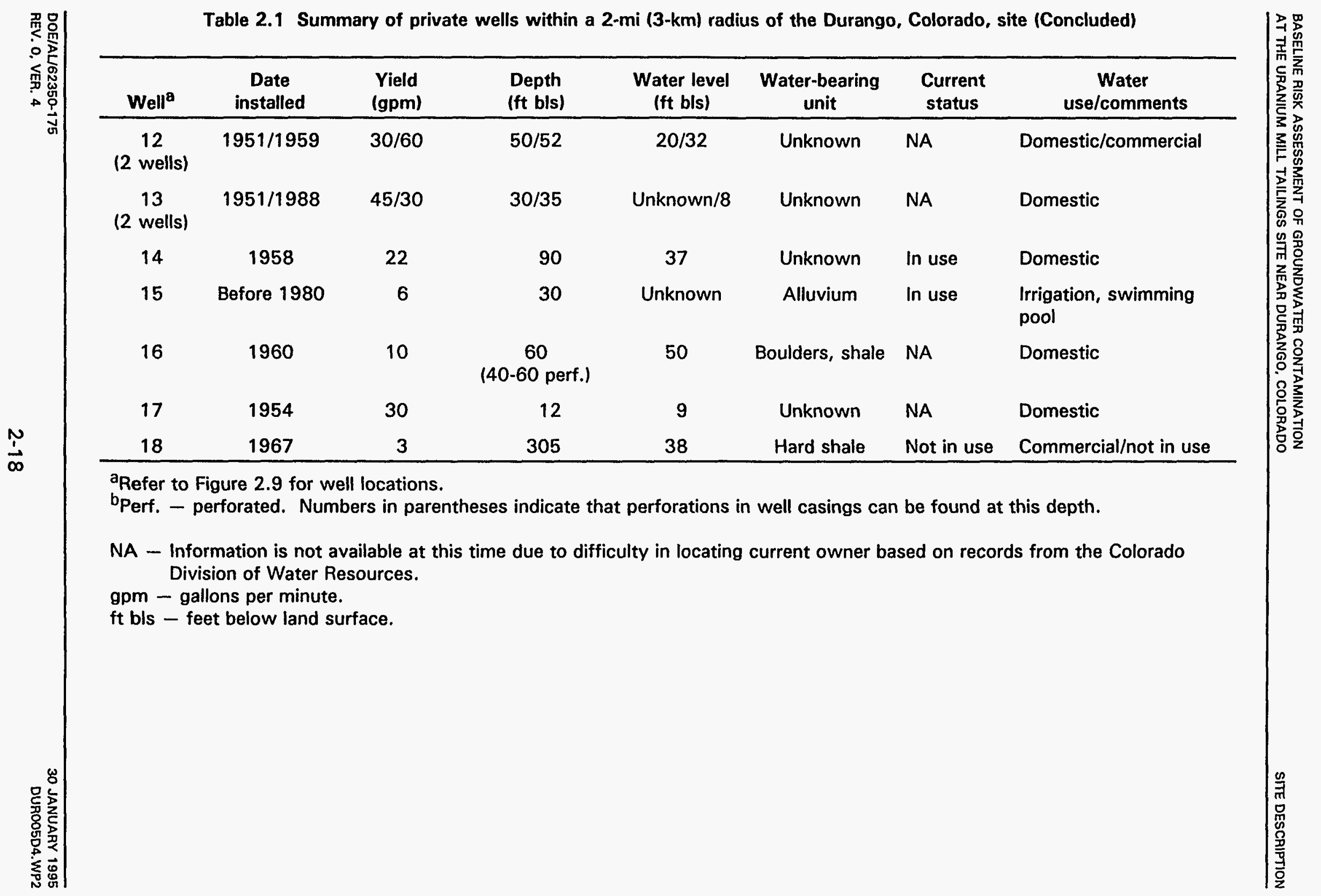



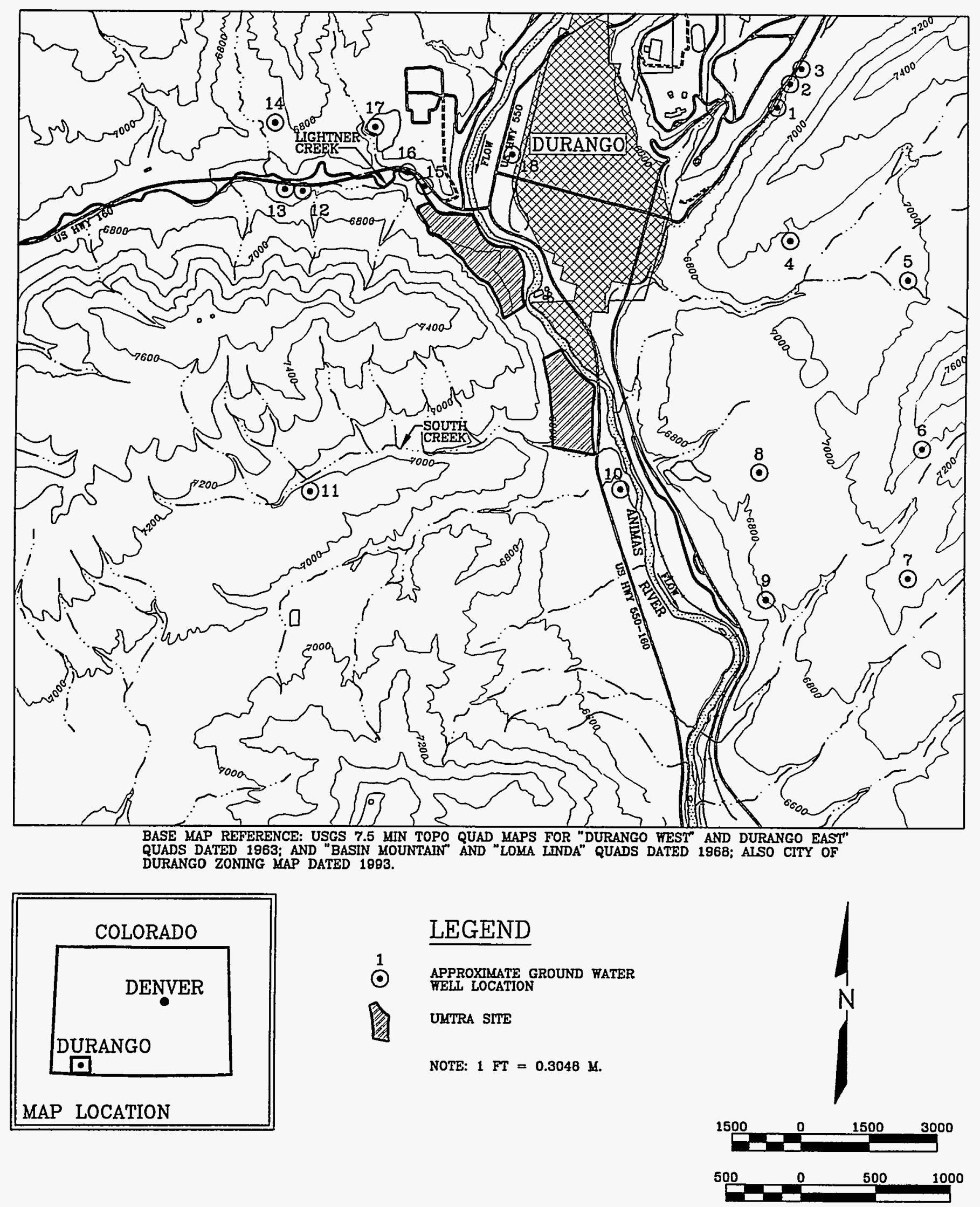

FIGURE 2.9 
and Table 2.1). However, this well is located under a building and has never been used because of black discoloration of the water (TAC, 1994a). Additional wells (numbers 1 through 9 in Figure 2.9) are on the opposite side of the Animas River and are at distances ranging from $0.8 \mathrm{mi}(1 \mathrm{~km})$ to $1.5 \mathrm{mi}(2 \mathrm{~km})$ from the site. All other wells in Figure 2.9 are north of Lightner Creek. None of these wells would be affected by contaminated ground water from the site. Contaminated ground water discharges to the Animas River, where it is quickly diluted (refer to Section 3.6). 


\subsection{MAGNITUDE AND EXTENT OF CONTAMINATION}

Ground water quality data from the processing site and vicinity were collected from 1982 through 1989 by the DOE and from 1990 through 1994 by both the DOE and the Bureau of Reclamation (BOR). These data and the associated statistical reports are available through the UMTRA Project Office (TAC, 1995). A total of 34 wells were sampled. These wells include 14 DOE monitor wells and 1 private irrigation well located at or upgradient of the former mill tailings area, 10 DOE monitor wells located at the former raffinate ponds area, and 9 wells owned by the BOR located at the former raffinate ponds area (Figures 3.1, 3.2, and 3.3). These wells were completed in several different hydrogeologic units, including the surficial deposits (colluvium and alluvium) and the Menefee Formation, Point Lookout Sandstone, and Mancos Shale bedrock. Three wells completed in bedrock are screened across a fault that transects the raffinate ponds area. In Table 3.1, these wells are compiled according to location (mill tailings area or raffinate ponds area) and hydrogeologic zone of completion.

In this assessment of the magnitude and extent of contamination, the mill tailings area and raffinate ponds area are treated separately for three reasons. First, the sources of contamination were different in each area. The mill tailings area was affected by tailings seepage, whereas the raffinate ponds area was affected by raffinates (waste solutions produced by acid leaching of the ores). Second, contamination in the two areas has affected different hydrogeologic units. In the mill tailings area, alluvial deposits are affected, and underlying bedrock is not. In the raffinate ponds area, the permeable sandstone bedrock is most affected. Finally, the two areas are hydrologically distinct, being separated by distance, a fault, and a cut bank along the Animas River.

Surface remediation removed sources of contamination, including the tailings piles, raffinate residue, and large volumes of contaminated colluvium and alluvium. Thus, in this risk assessment, ground water quality data collected from May 1990 through June 1994 (after surface remediation) are used to determine the magnitude of contamination and to evaluate risks. This time period allowed for incorporation of at least 4 years of data from each well, including the most recent information available.

Most ground water samples were filtered prior to analysis during the period from May 1990 to 1994 . One set of unfiltered samples was collected and analyzed for nearly all constituents from two wells at the raffinate ponds area (DUR-02-601 and -607) and from three wells in the mill tailings area (DUR-01-612, -617 , and -622). A second set of unfiltered samples was collected from the same wells in 1993. However, a more limited set of constituents was analyzed in this second sampling , including arsenic, cadmium, iron, manganese, molybdenum, lead, selenium, vanadium, zinc, mercury, radium-226, radium-228, thorium-230, and uranium. Where available, both filtered and unfiltered data are used in this risk assessment. An analysis of paired filtered and unfiltered data indicates that, for most constituents, there is little difference. The exceptions are iron and lead, which are at higher concentrations in the unfiltered samples (Table 3.2) (TAC, 1995).

After remediation was completed in May 1991, three wells remained in the tailings area (DUR-01-612, -617, and -622) and two in the raffinate ponds area (DUR-02-602 and 


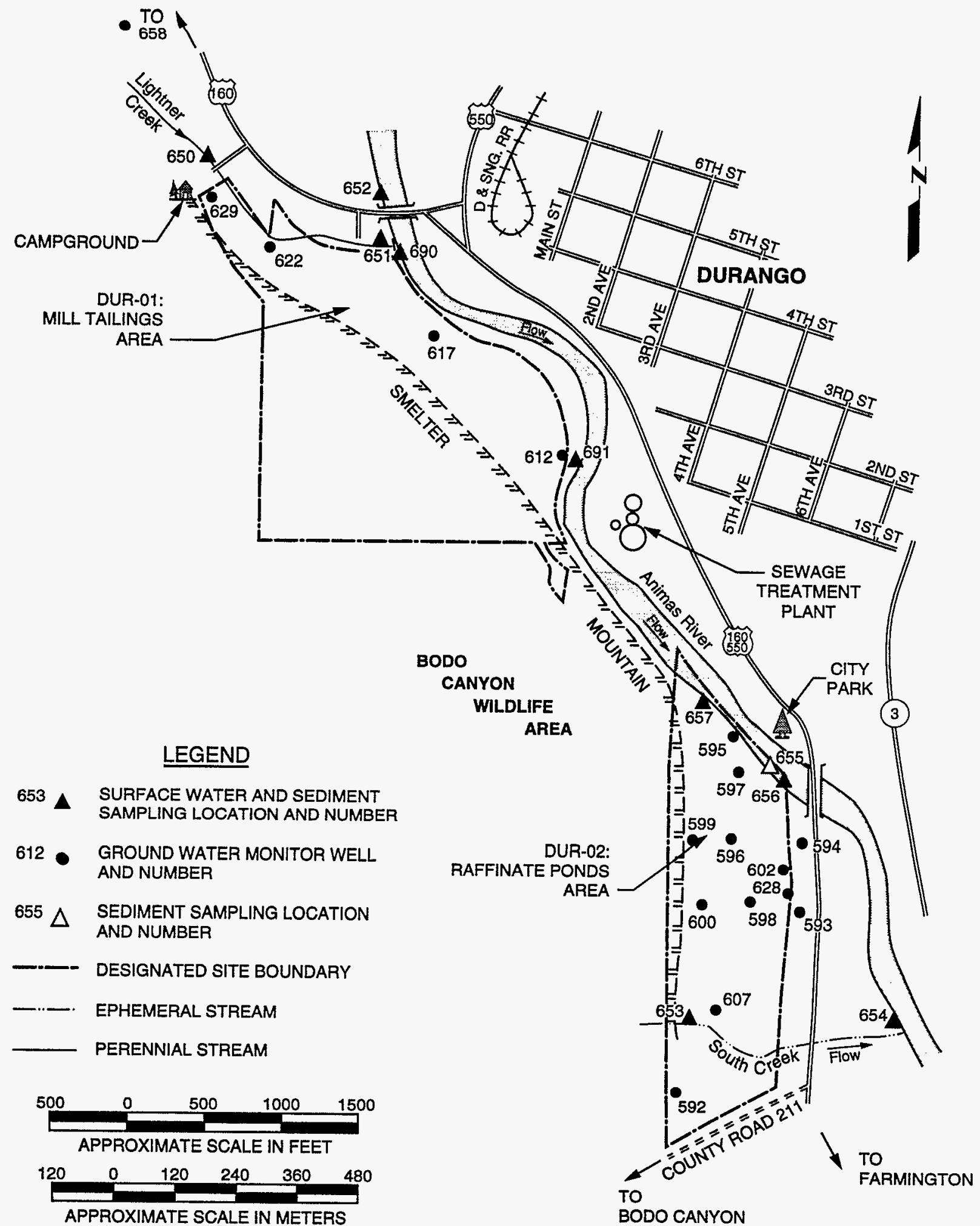

FIGURE 3.1

EXISTING MONITOR WELL, SURFACE WATER, AND SEDIMENT SAMPLING LOCATIONS IN THE MILL TAILINGS AREA AND RAFFINATE PONDS AREA DURANGO, COLORADO, SITE 


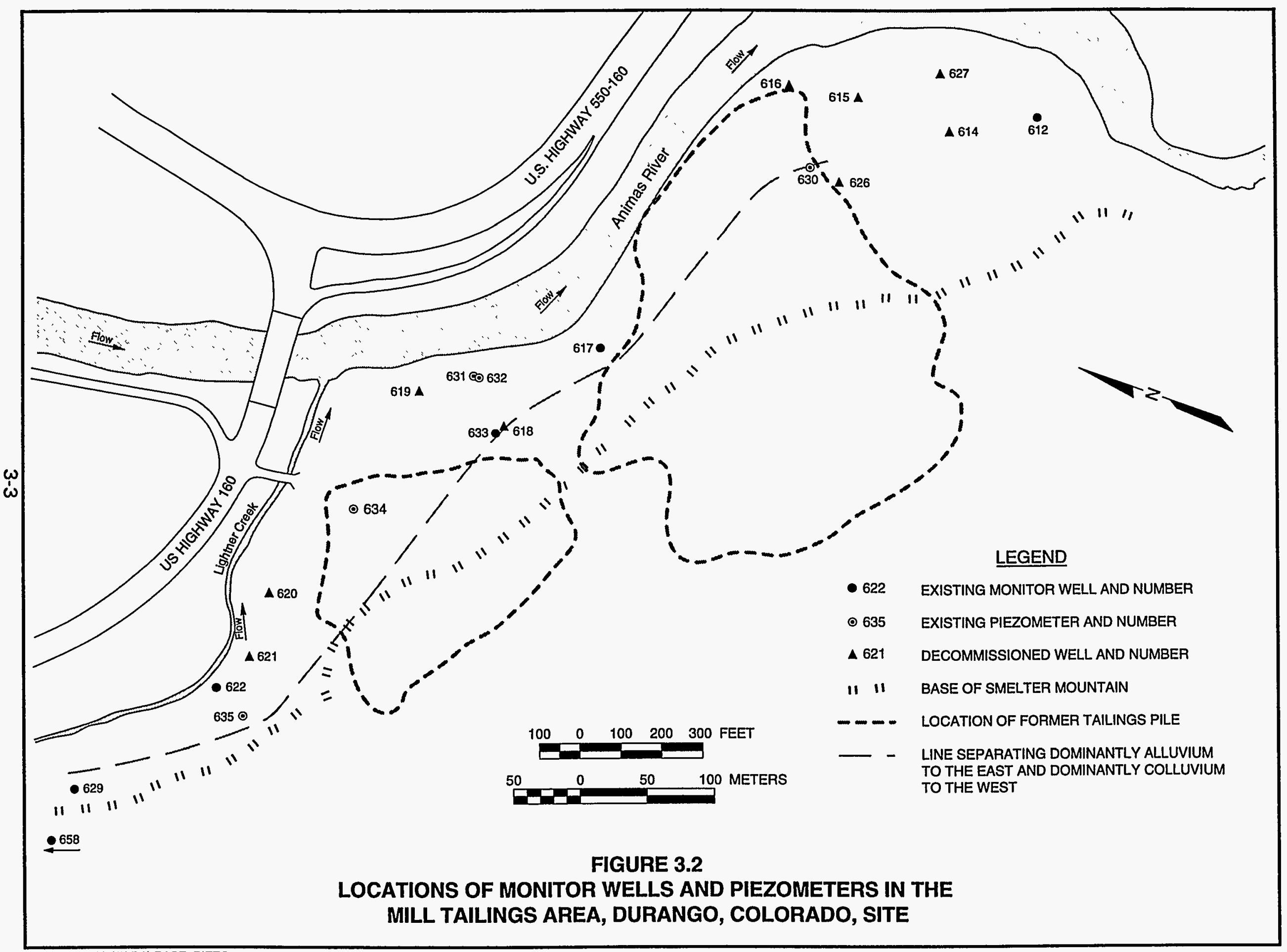




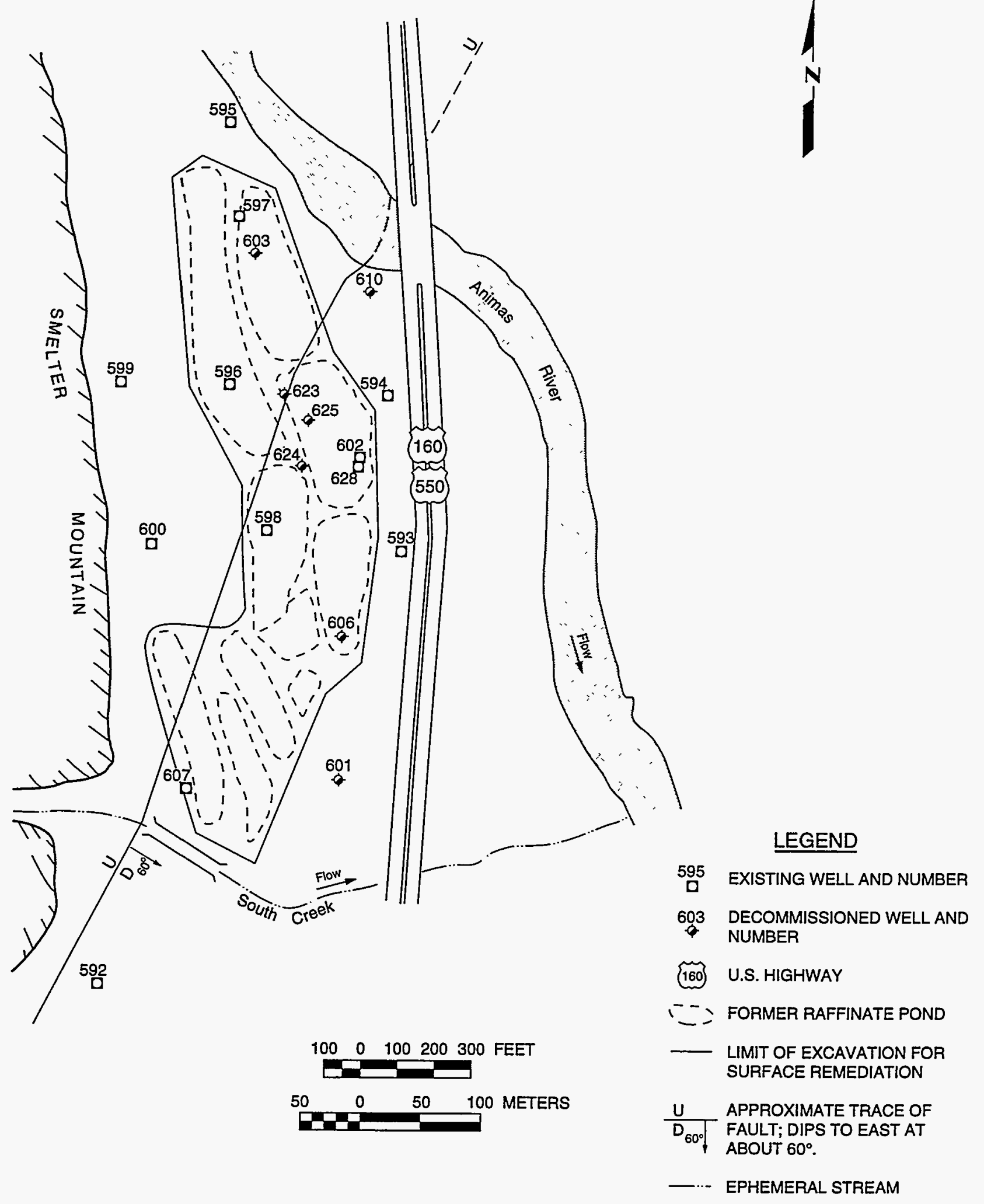

FIGURE 3.3

LOCATIONS OF MONITOR WELLS IN THE RAFFINATE PONDS AREA DURANGO, COLORADO, SITE 


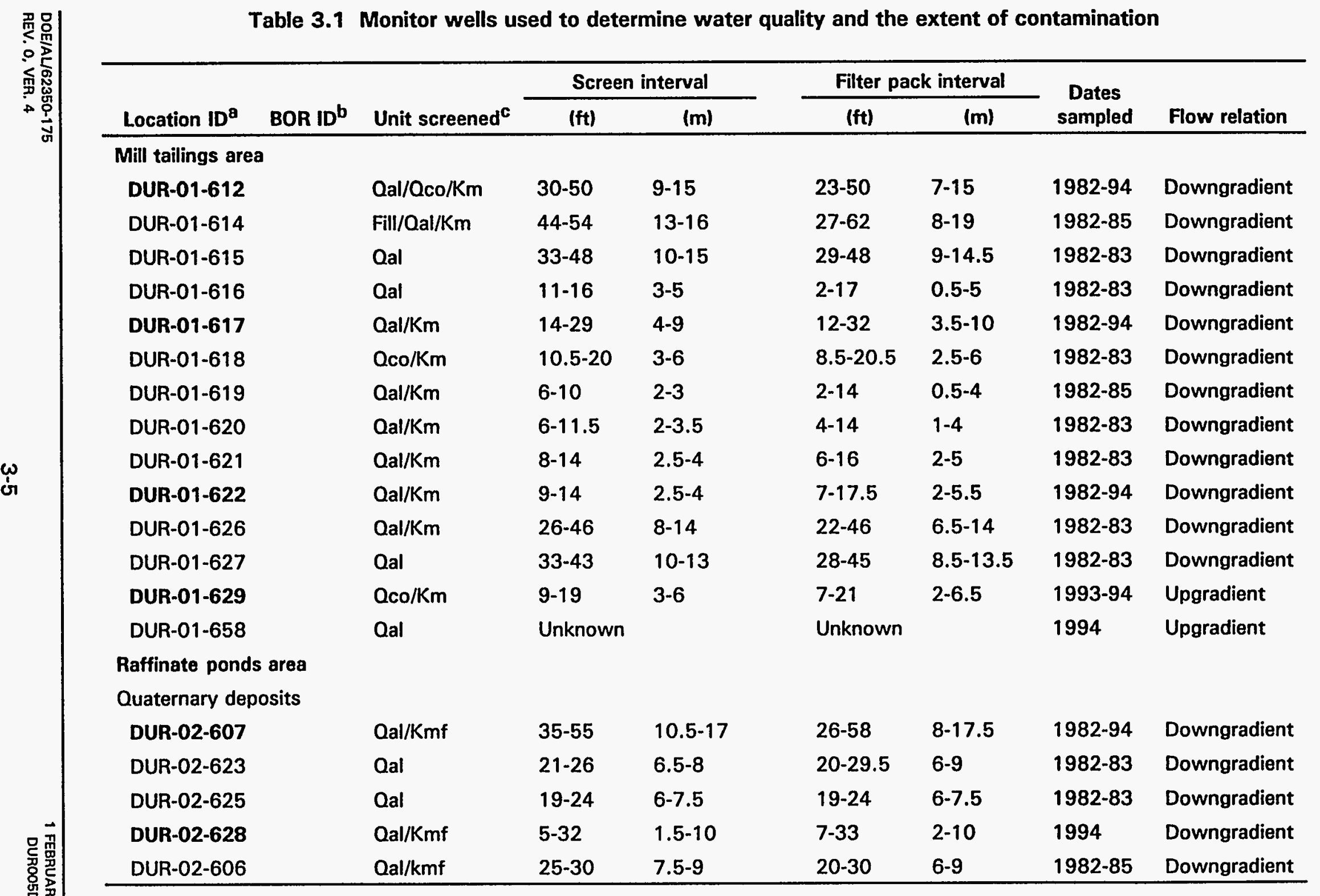




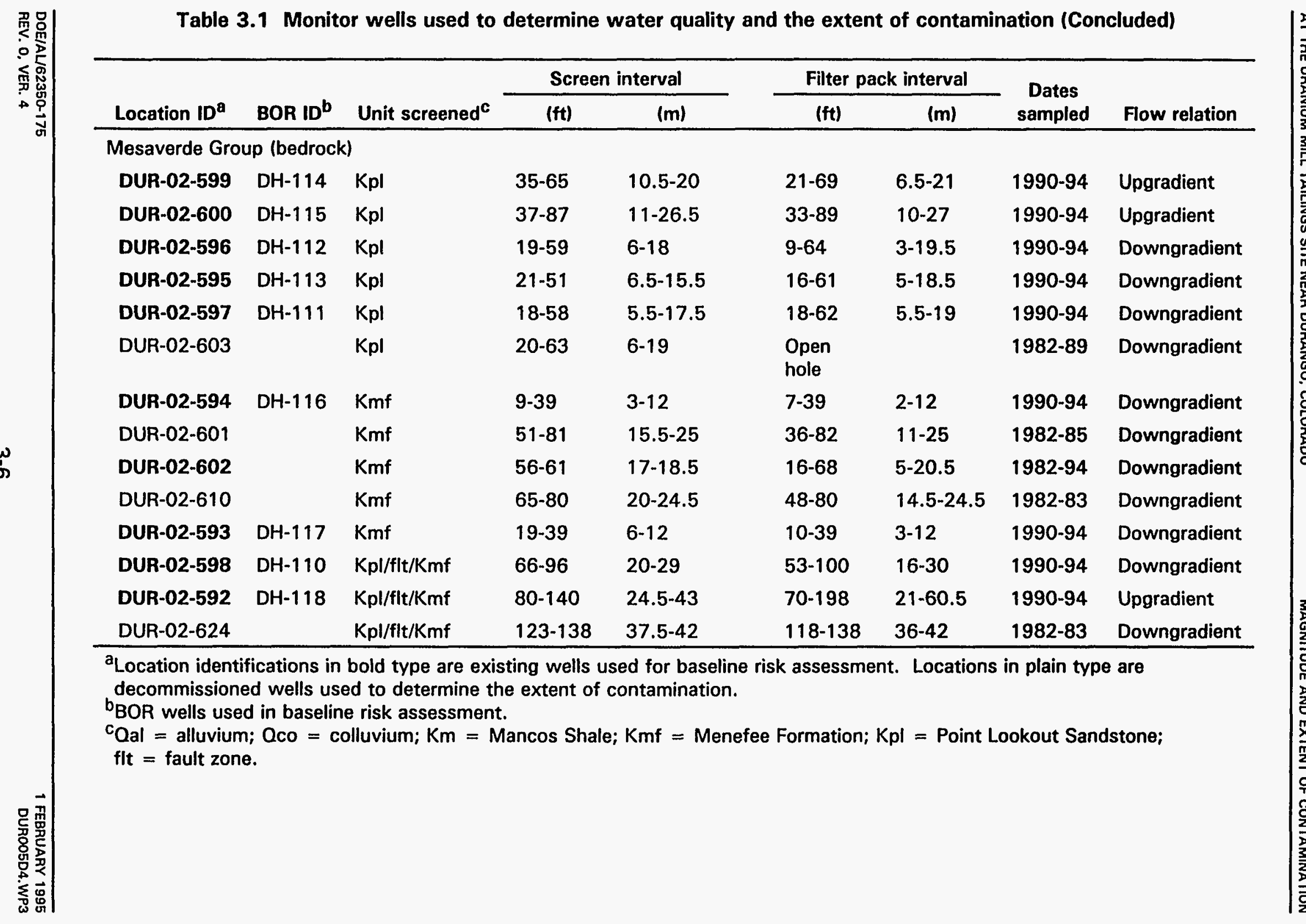




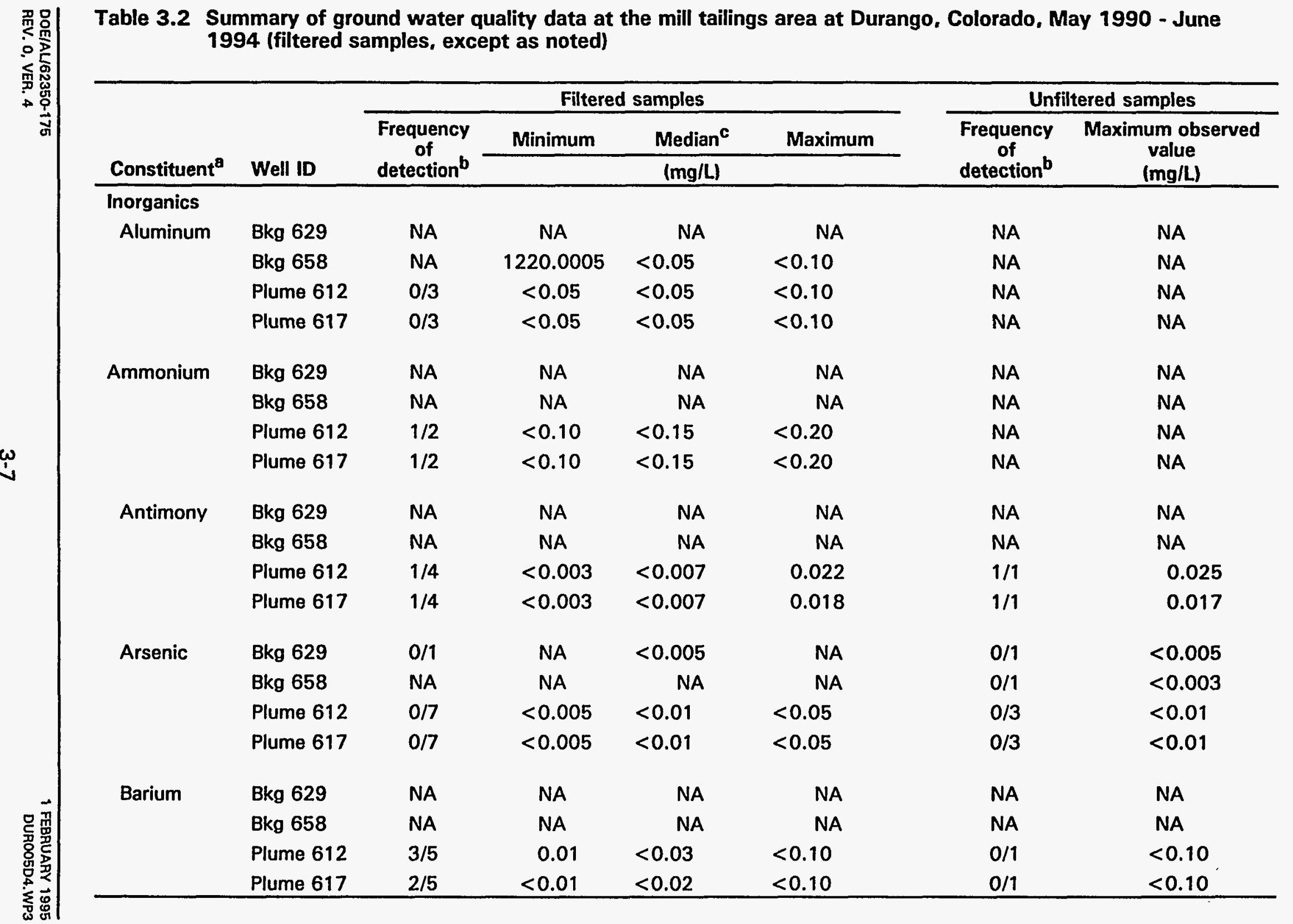




\begin{tabular}{|c|c|c|c|c|c|c|c|}
\hline \multirow{3}{*}{ 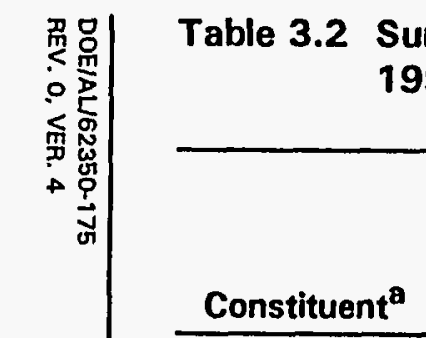 } & \multirow[b]{3}{*}{ Well ID } & \multicolumn{4}{|c|}{ Filtered samples } & \multicolumn{2}{|c|}{ Unfiltered samples } \\
\hline & & \multirow{2}{*}{$\begin{array}{c}\text { Frequency } \\
\text { of } \\
\text { detection }\end{array}$} & Minimum & Medianc & Maximum & \multirow{2}{*}{$\begin{array}{c}\text { Frequency } \\
\text { of } \\
\text { detection }\end{array}$} & \multirow{2}{*}{$\begin{array}{c}\text { Maximum observed } \\
\text { value } \\
\text { (mg/L) }\end{array}$} \\
\hline & & & & (mg/L) & & & \\
\hline Inorganics & & & & & & & \\
\hline Beryllium & Bkg 629 & NA & NA & NA & NA & NA & NA \\
\hline & Bkg 658 & NA & NA & NA & NA & NA & NA \\
\hline & Plume 612 & $0 / 3$ & $<0.005$ & $<0.01$ & $<0.01$ & $0 / 1$ & $<0.01$ \\
\hline & Plume 617 & $0 / 3$ & $<0.005$ & $<0.01$ & $<0.01$ & $0 / 1$ & $<0.01$ \\
\hline Cadmium & Bkg 629 & $0 / 1$ & NA & $<0.001$ & NA & $0 / 1$ & $<0.001$ \\
\hline & Bkg 658 & NA & NA & NA & NA & $0 / 1$ & $<0.001$ \\
\hline & Plume 612 & $6 / 7$ & $<0.001$ & 0.038 & 0.070 & $3 / 3$ & $<0.05$ \\
\hline$\infty$ & Plume 617 & $1 / 7$ & $<0.001$ & $<0.001$ & 0.003 & $0 / 3$ & $<0.001$ \\
\hline Calcium & Bkg 629 & $1 / 1$ & NA & 278 & NA & $1 / 1$ & 273 \\
\hline & Bkg 658 & NA & NA & NA & NA & $1 / 1$ & 85 \\
\hline & Plume 612 & $7 / 7$ & 226 & 424 & 477 & $3 / 3$ & 451 \\
\hline & Plume 617 & $7 / 7$ & 466 & 481 & 499 & $3 / 3$ & 496 \\
\hline Chloride & Bkg 629 & $1 / 1$ & NA & 23.9 & NA & $1 / 1$ & 25.6 \\
\hline & Bkg 658 & $1 / 1$ & NA & NA & NA & $1 / 1$ & 8.2 \\
\hline & Plume 612 & $6 / 6$ & 308 & 697 & 795 & $3 / 3$ & 952 \\
\hline & Plume 617 & $6 / 6$ & 50 & 67 & 75 & $3 / 3$ & 66 \\
\hline \multirow{4}{*}{ 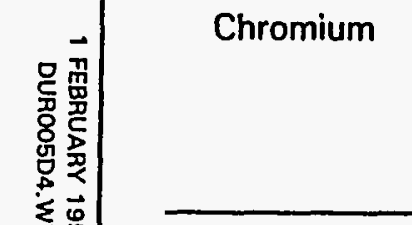 } & Bkg 629 & NA & NA & NA & NA & NA & NA \\
\hline & Bkg 658 & NA & NA & NA & NA & NA & NA \\
\hline & Plume 612 & $0 / 5$ & $<0.01$ & $<0.01$ & $<0.01$ & $0 / 1$ & $<0.05$ \\
\hline & Plume 617 & $0 / 5$ & $<0.01$ & $<0.01$ & $<0.01$ & $0 / 1$ & $<0.05$ \\
\hline
\end{tabular}




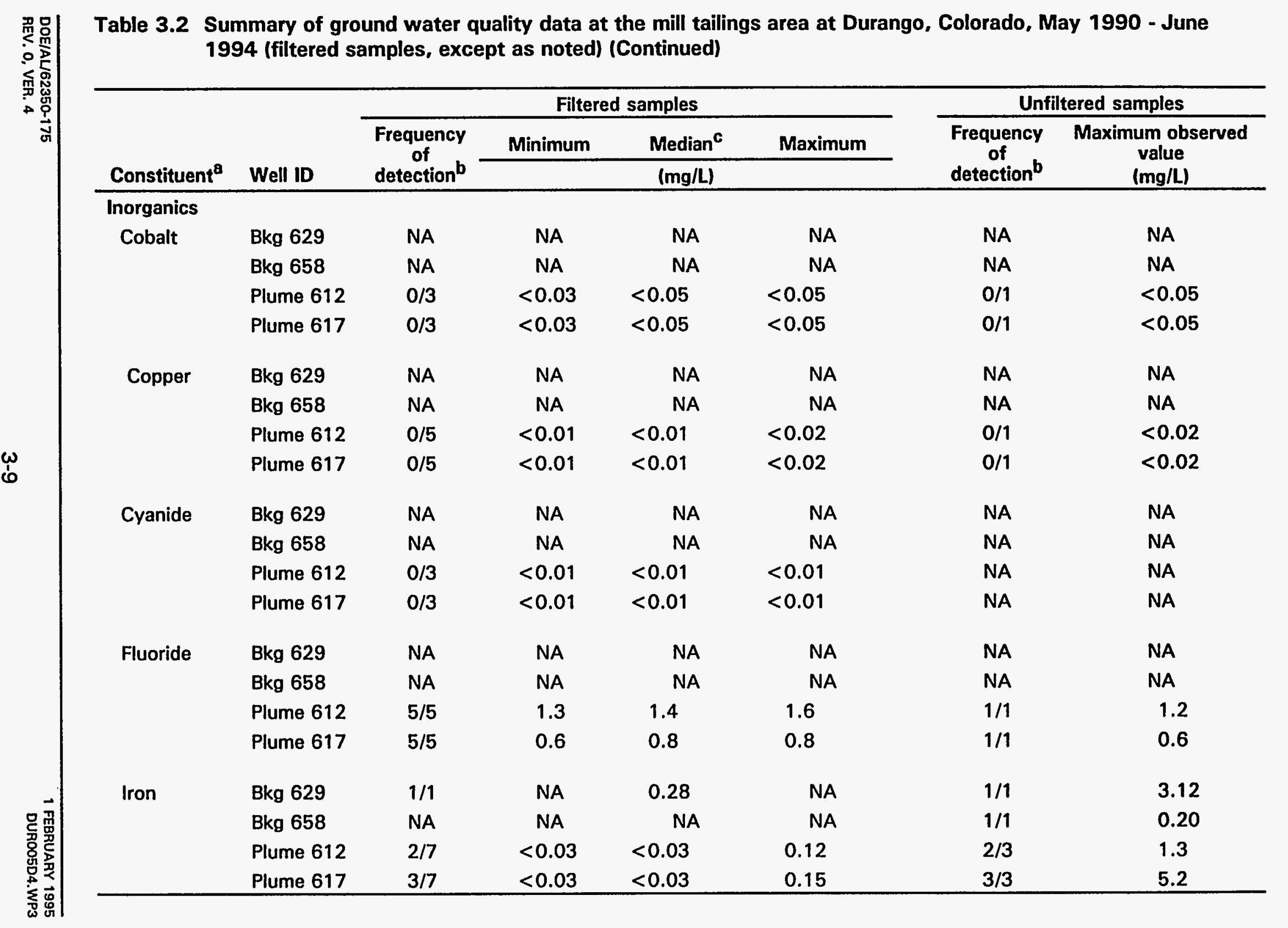




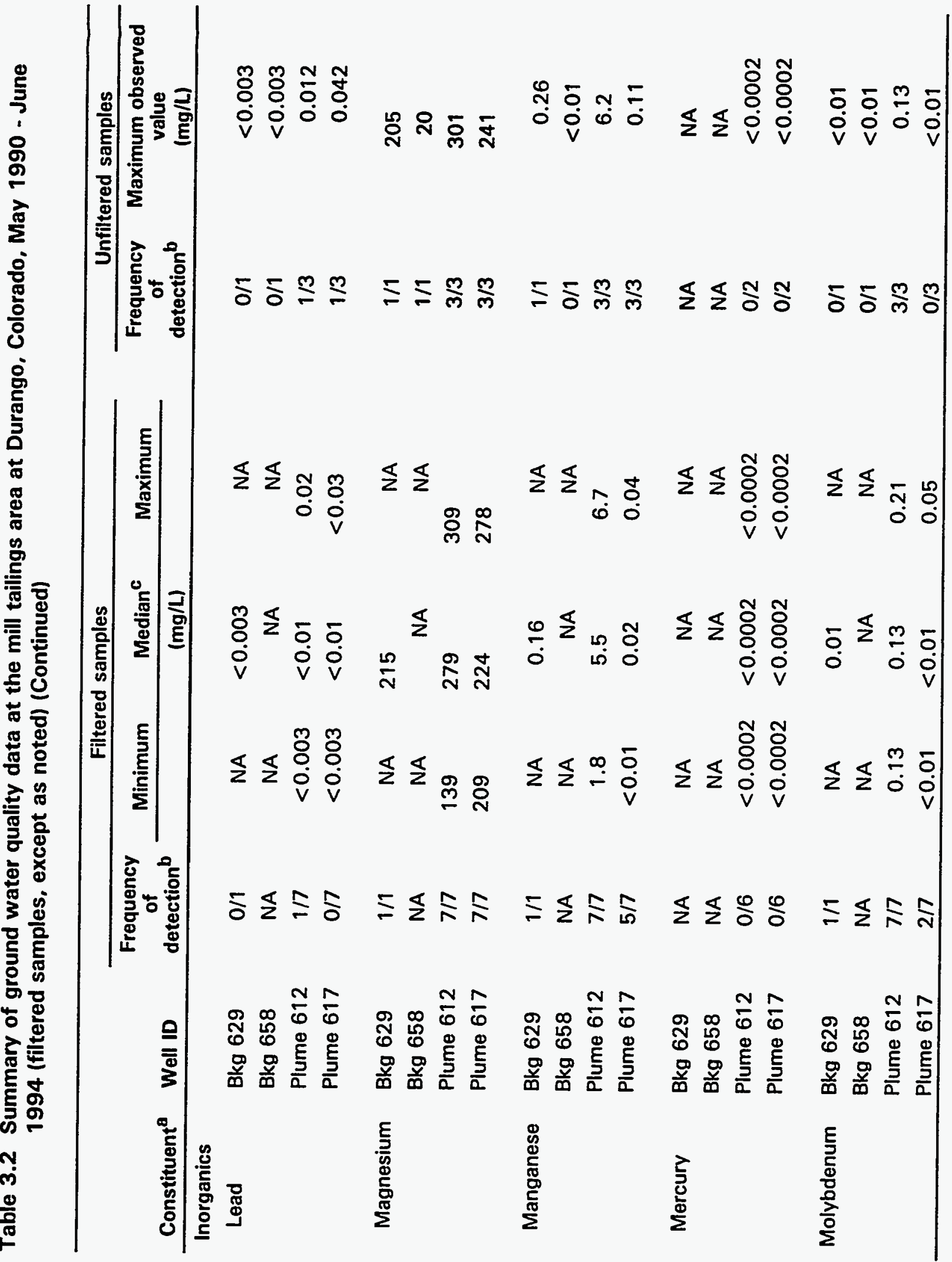




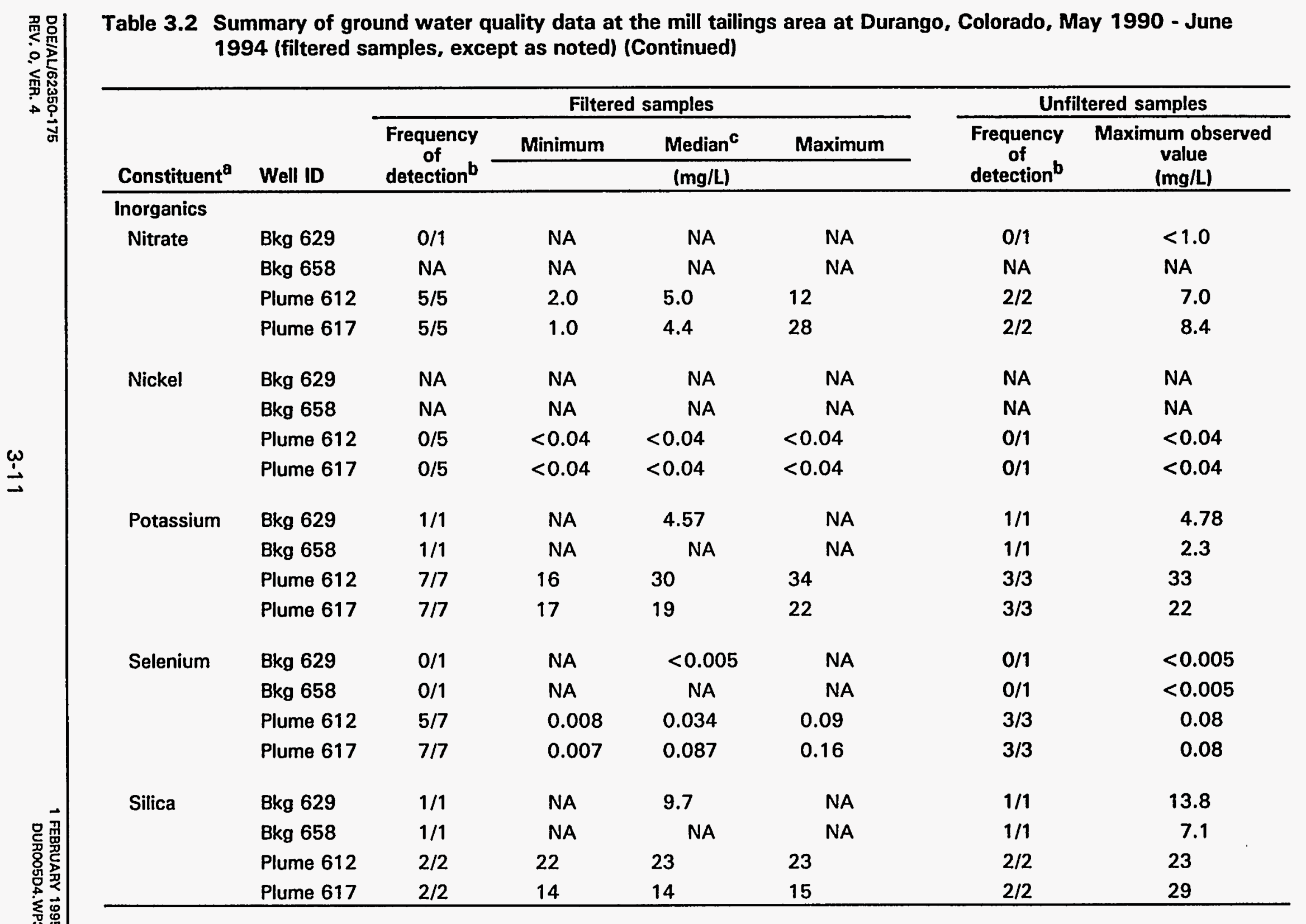




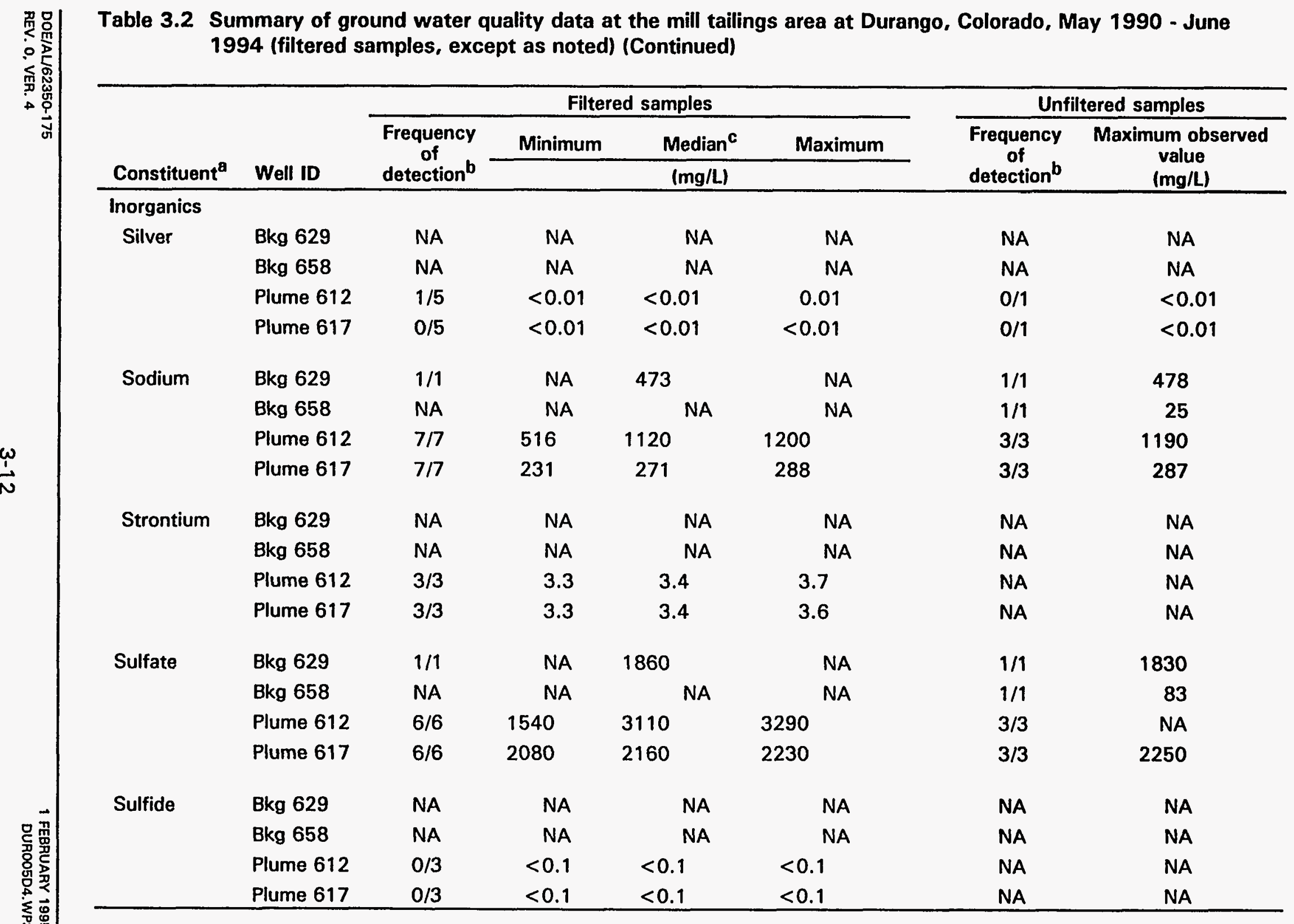




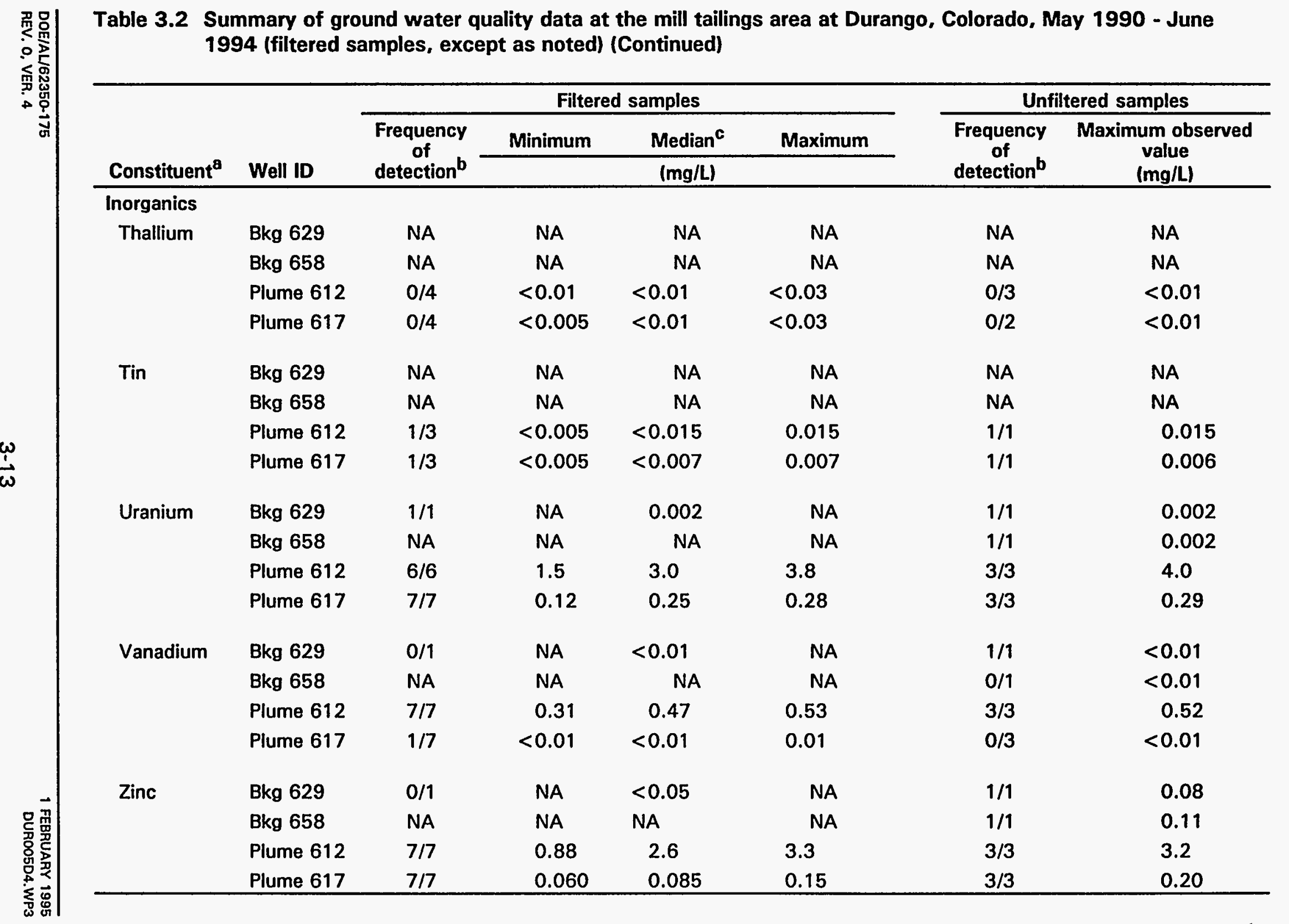




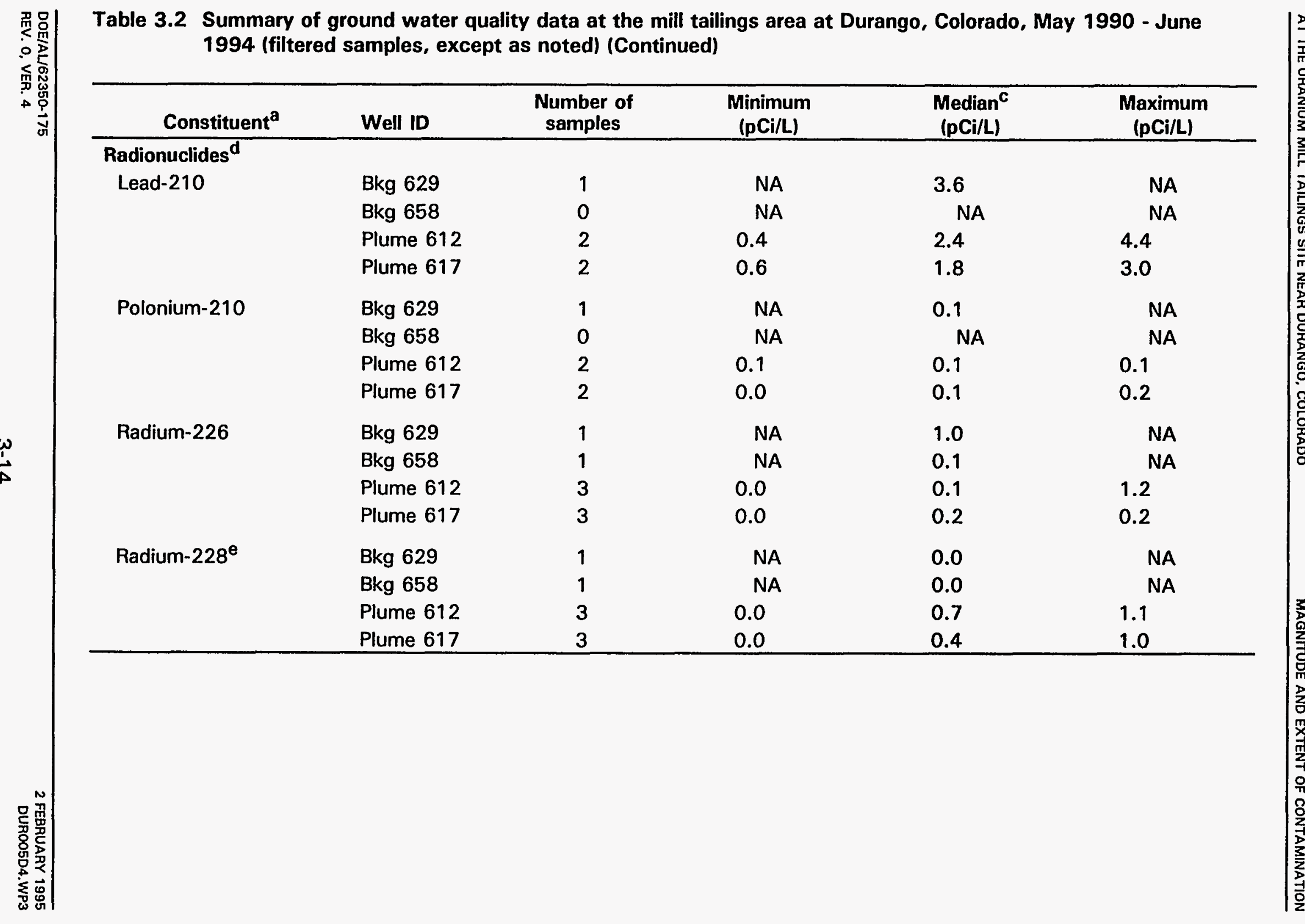




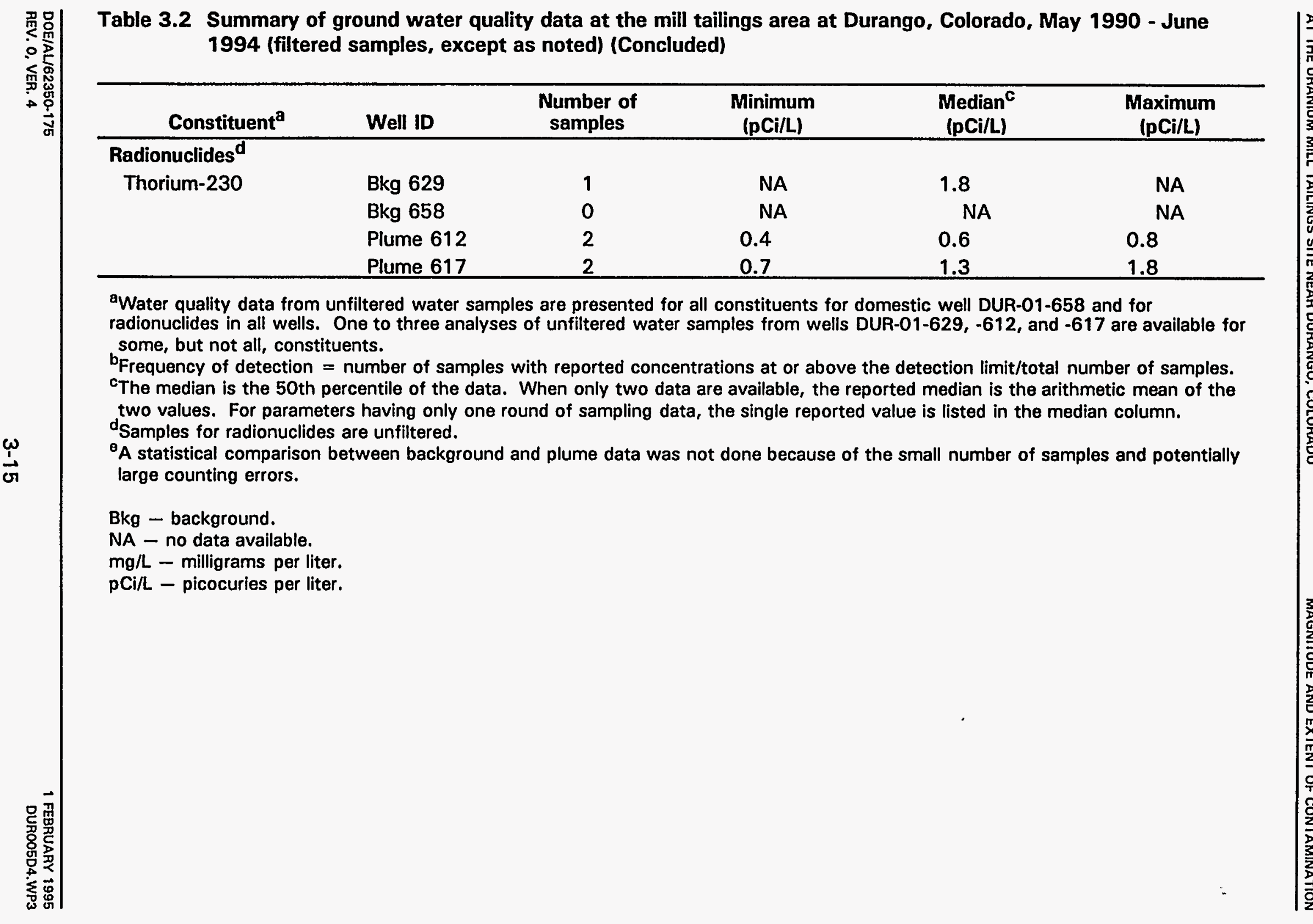


-607). These wells were sampled seven times between May 1990 and June 1994. The BOR constructed nine wells in the ponds area; these were sampled by the BOR four times in 1993 and 1994. For three of these BOR wells (DUR-02-598, -599, and -600), the DOE conducted two independent rounds of sampling and analysis in late 1993 and 1994. In addition, monitor wells DUR-01-628 and -629 were installed and sampled for this risk assessment. The last source of ground water quality data is a private irrigation well completed in the alluvium upgradient of the mill tailings area. In June 1994, the DOE collected and analyzed an unfiltered sample from this well.

Chemical data and supporting quality control information were obtained from the BOR for the purposes of this risk assessment. Review of quality control information determined that the data meet Level $C$ quality control criteria as defined by the DOE (DOE, 1990).

In 1990, ground water from the mill tailings area (wells DUR-01-617 and -622) and from the raffinate ponds area (well DUR-02-602) was screened for organic constituents (DOE, 1991) listed in Appendix IX of 40 CFR Part 264 (1994) of the Resources Conservation and Recovery Act. None of these organic constituents were detected in the screening. However, organic solvents used in the uranium milling process, discussed in Section 2.1, were not analyzed for in ground water.

Surface water and sediment samples were collected from the Animas River, Lightner Creek, and South Creek (Figure 3.1). Ten sediment samples and nine filtered and unfiltered surface water samples were collected during November 1993 at the locations shown in Figure 3.1.

Water samples were collected in accordance with applicable standard operating procedures described in the Albuquerque Operations Manual (JEG, n.d.). BOR water samples were collected using similar procedures.

\section{$3.1 \quad$ BACKGROUND WATER QUALITY SUMMARY}

\section{Mill tailings area}

Background ground water quality is defined as the quality of water if uranium milling activities had not taken place. Background ground water quality data for conditions at the mill tailings area are available from upgradient monitor well DUR-01-629, completed in the colluvium overlying the Mancos Shale on Smelter Mountain, and private irrigation well DUR-01-658, completed in alluvial gravel near Lightner Creek (Figure 3.1). Background ground water quality at the site is of two types: ground water occurring in colluvium above the Mancos Shale near the base of Smelter Mountain and ground water occurring in gravel near the streams. Monitor well DUR-01-629 and private well DUR-01-658 represent the two types of background ground water at the site.

There are two rounds of data: one from monitor well DUR-01-629 and one from private well DUR-01-658 (Table 3.1). Because monitor well DUR-01-629 is completed in clay-rich colluvial materials, it contains very little water and tends to pump dry during sampling events. Each time the well is pumped dry, 
the possibility of disturbance to the aquifer matrix exists and unfiltered sample results will not be representative of ground water conditions in the well. Private well DUR-01-658, which is completed in alluvial gravel, has been in place for several years, is pumped regularly, and has much higher yields. Thus, private well DUR-01-658 has been extensively developed and the aquifer matrix has stabilized. It is therefore reasonable to compare filtered data from monitor well DUR-01-629 with unfiltered data from private well DUR-01-658.

Background ground water quality data clearly show the two distinctly different water types and sources that contribute to the ground water in the colluvial and gravel materials in the Durango mill tailings area (Table 3.2). Ground water in the colluvium close to the toe of Smelter Mountain (Figure 3.2), represented by background monitor well DUR-01-629, is a sodium-sulfate type (containing significant concentrations of calcium and magnesium) with relatively high total dissolved solids (TDS) (3500 milligrams per liter [mg/L]). By contrast, ground water in the gravelly alluvium closer to the river, represented by background private well DUR-01-658, is a calcium-bicarbonate type with low TDS (not measured directly, but estimated at $400 \mathrm{mg} / \mathrm{L}$ from concentrations of major species measured). The pH of ground water in both wells is close to neutral (7.0 in well DUR-01-629 and 7.08 in well DUR-01-658). The difference in water chemistry between these two wells is likely related to equilibration of ground water in monitor well DUR-01-629 with gypsum and clay minerals known to be present in colluvial materials.

\section{Raffinate ponds area}

Before remediation, ground water in the area of the raffinate ponds occurred in both the surficial deposits and the bedrock. At present, ground water in the raffinate ponds area occurs primarily in the bedrock units located beneath surficial deposits. Regional ground water quality data for the Mesaverde Group (Butler, 1986) are summarized in Table 3.3. These data are from an area of about $600 \mathrm{mi}^{2}\left(1550 \mathrm{~km}^{2}\right)$ surrounding Durango and include 35 ground water sampling locations. The regional data indicate that water quality is variable in the Mesaverde Group. For example, sulfate concentrations vary from 0.5 to $2000 \mathrm{mg} / \mathrm{L}$, and chloride concentrations vary from 1 to $93 \mathrm{mg} / \mathrm{L}$. Several trace elements are present, including iron (averaging $0.89 \mathrm{mg} / \mathrm{L}$ ), lead (averaging $0.033 \mathrm{mg} / \mathrm{L}$ ), manganese (averaging $0.08 \mathrm{mg} / \mathrm{L}$ ), and molybdenum (averaging $0.014 \mathrm{mg} / \mathrm{L}$ ) (Table 3.3).

Near the site, background water quality data for the raffinate ponds area are available from one monitor well located in the far southwest corner of the site and upgradient of the raffinate ponds area (monitor well DUR-02-592). This monitor well is separated from the site by South Creek, which would have acted as a barrier to any contaminant migration caused by development of a ground water mound during operations at the raffinate ponds area. Also, the monitor well is located in an area unaffected by surface operations associated with former uranium processing and surface remediation. Monitor well DUR-02-592 is screened across a fault contact between the Menefee and Point Lookout 
Table 3.3 Comparison of regional ground water quality data for the Mesaverde Group to background water quality data from the raffinate ponds area ${ }^{a}$

\begin{tabular}{|c|c|c|c|c|c|c|}
\hline & \multicolumn{3}{|c|}{ Mesaverde Group } & \multicolumn{3}{|c|}{$\begin{array}{c}\text { Raffinate ponds area } \\
\text { Background well DUR-02-592 }\end{array}$} \\
\hline & Minimum & Maximum & Mean & Minimum & Maximum & Mean \\
\hline Depth (feet) & 57 & 426 & 158 & 80 & 140 & 110 \\
\hline Depth (meters) & 17 & 130 & 48 & 24 & 43 & 34 \\
\hline \multicolumn{7}{|l|}{ Parameter } \\
\hline Alkalinity & 102 & 1010 & 515 & 740 & 820 & 773 \\
\hline Arsenic & $<0.001$ & 0.003 & $<0.001$ & $<0.005$ & $<0.005$ & $<0.005$ \\
\hline Boron & 0.02 & 0.42 & 0.18 & NA & NA & NA \\
\hline Calcium & 0.6 & 340 & 63 & 110 & 120 & 115 \\
\hline Cadmium & $<0.001$ & 0.004 & $<0.002$ & $<0.0001$ & $<0.005$ & $<0.003$ \\
\hline Chloride & 1.2 & 93 & 15 & 62 & 69 & 66 \\
\hline Copper & $<0.001$ & 0.017 & 0.003 & $<0.005$ & $<0.005$ & $<0.005$ \\
\hline Fluoride & 0.1 & 4.3 & 1.3 & NA & NA & NA \\
\hline Iron & $<0.01$ & 20 & 0.89 & 0.02 & 0.02 & 0.02 \\
\hline Lead & $<0.001$ & 0.160 & 0.033 & $<0.001$ & $<0.005$ & $<0.005$ \\
\hline Magnesium & $<0.1$ & 280 & 37 & 150 & 160 & 155 \\
\hline Manganese & $<0.01$ & 1.1 & 0.08 & 0.05 & 0.07 & 0.06 \\
\hline Mercury & $<0.0001$ & 0.002 & $<0.0001$ & $<0.0001$ & $<0.0001$ & $<0.0001$ \\
\hline Molybdenum & $<0.001$ & 0.025 & 0.014 & $<0.01$ & $<0.01$ & $<0.01$ \\
\hline Nickel & $<0.001$ & 0.025 & 0.004 & $<0.001$ & $<0.02$ & $<0.02$ \\
\hline Nitrate & 0.09 & 7.1 & 0.7 & $<0.2$ & $<0.2$ & .3 \\
\hline $\mathrm{pH}$ & 6.3 & 8.7 & 7.5 & 7.6 & 8.0 & 8.0 \\
\hline Potassium & 0.6 & 23 & 3.3 & 5.7 & 6.6 & 6.2 \\
\hline Silica & 7 & 22 & 12 & 8.5 & 9.0 & 9 \\
\hline Sodium & 8 & 670 & 238 & 240 & 250 & 245 \\
\hline Sulfate & 0.5 & 2000 & 293 & 560 & 680 & 650 \\
\hline TDS & 130 & 3300 & 976 & 1700 & 1700 & 1700 \\
\hline
\end{tabular}

a All data in milligrams per liter except for $\mathrm{pH}$ (standard units).

b Mesaverde Group data from Butler, 1986.

NA - not analyzed. 
Sandstone and thus produces ground water from both units and the intervening fault zone. A comparison of the water quality from this well to regional ground water quality in the Mesaverde Group indicates that ground water from DUR-02592 is within the range of regional ground water quality for all measured constituents (Table 3.3).

Trace elements and heavy metals are generally not present at levels above detection limits in the background well (Table 3.3). The $\mathrm{pH}$ of the water is above neutral (about $8 \mathrm{pH}$ units), and the TDS is about $1700 \mathrm{mg} / \mathrm{L}$.

\subsection{MAGNITUDE OF SITE-RELATED CONTAMINATION}

Salt roasting, carbonate leaching, and acid leaching of vanadate ores contributed sodium chloride $(\mathrm{NaCl})$, sodium carbonate $\left(\mathrm{Na}_{2} \mathrm{CO}_{3}\right)$, and sodium perchlorate $\left(\mathrm{NaClO}_{4}\right)$ to the alkaline leach tails and hydrochloric acid $(\mathrm{HCl})$, sulfuric acid $\left(\mathrm{H}_{2} \mathrm{SO}_{4}\right)$ and potassium permanganate $\left(\mathrm{KMnO}_{4}\right)$ to the acid leach tails. Mixing of the overflow from alkaline leach tails with acid tailings in the tailings piles produced solutions that seeped through the tailings and into the ground water system in the mill tailings area. Raffinate was disposed of in ponds and seeped from the ponds into the ground water system in the raffinate ponds area.

Both the seepage from the tailings piles and the raffinate were chemically analyzed in 1959 (Tsivoglou et al., 1960). The analyses indicate that while both sources of contamination contained a similar suite of contaminants, the tailings seepage was more dilute and had a higher $\mathrm{pH}$ than the raffinate (Table 3.4). Tailings seepage had a pH of 4.1 and TDS of $8450 \mathrm{mg} / \mathrm{L}$. By contrast, the raffinate had a pH of 0.8 and a TDS of $120,000 \mathrm{mg} / \mathrm{L}$. Both sources of contamination contained constituents derived from processing reagents, including sodium, sulfate, chloride, and manganese. Other constituents, derived from the dissolution of the ores, included arsenic, beryllium, copper, fluoride, iron, radium-226, vanadium, and zinc (Table 3.4). Dissolved selenium was notably absent in the contaminant sources. However, selenium was reported in the main plant effluent (Tsivoglou et al., 1960) and occurs in contaminated ground water at the site.

The differences in initial concentrations of contaminants in tailings seepage and raffinate explain the similar differences in contaminant concentrations in ground water in the mill tailings area (DUR-01-612) compared to ground water in the raffinate ponds area (DUR-02-598) (Table 3.4). In the raffinate ponds area, sulfate, sodium, and chloride concentrations in the ground water are less than those reported in the raffinate. However, geochemical modeling of the effect of neutralization and cation exchange indicates that these reactions within the aquifer matrix can explain lower concentrations of sulfate, sodium, iron, and manganese observed in historical data from the alluvium (DUR-02-625) and in recent data from the fault (DUR-02-598) (Table 3.5). Thus, ground water quality within the contaminated aquifer at the site reflects both the source of contamination and the reactions of the raffinate with the aquifer matrix. 


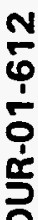

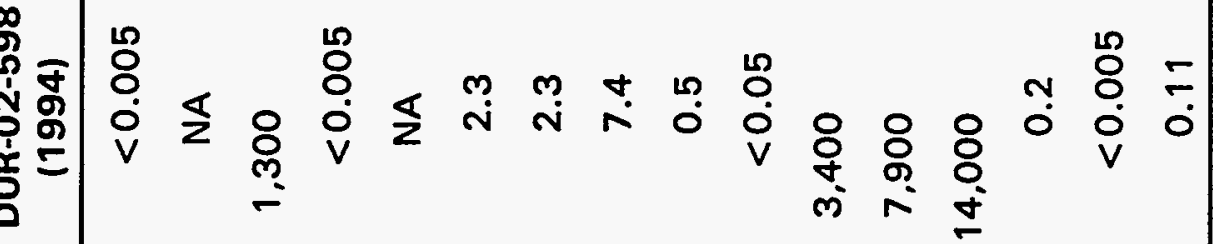

을

흐

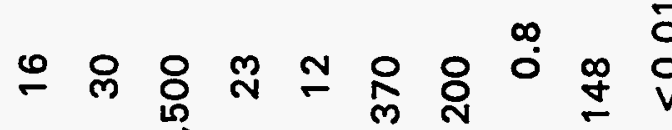

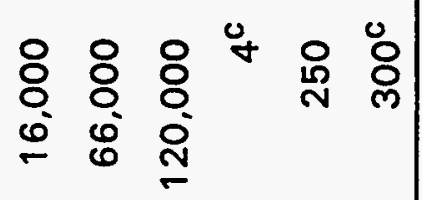

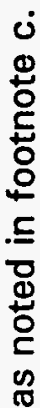

过

$\frac{1}{2}$

แัน

ธั.

요

\&

는

赵

$\frac{3}{\infty}$

疍

o

ชั่

잉

产

온

48

등

용

密

ㅎํㅇㅇํㅇ

$s$

$\stackrel{9}{0}$

둥

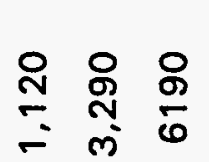

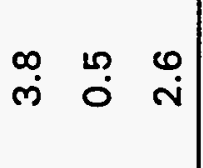

İ $\frac{\dot{0}}{\sigma}$

ด

०ं

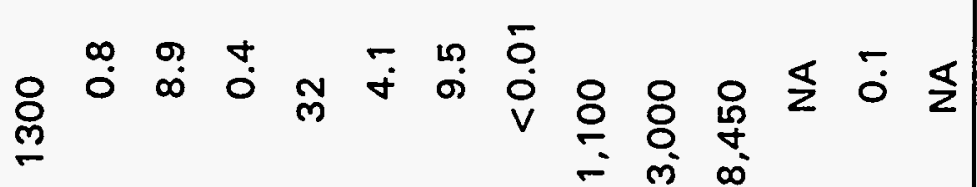

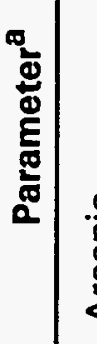

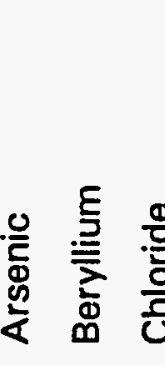

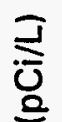

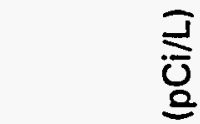

\$

$\frac{0}{10}$ 


\begin{tabular}{|c|c|c|c|c|c|c|}
\hline \multirow{2}{*}{ 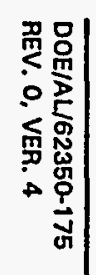 } & \multicolumn{6}{|l|}{ Table 3.5} \\
\hline & Parameter & Raffinate $^{\text {b }}$ & $\begin{array}{c}\text { Modeled neutralized } \\
\text { raffinate }^{c}\end{array}$ & $\begin{array}{c}\text { DUR-02-625 } \\
(1983) \\
\end{array}$ & $\begin{array}{c}\text { Modeled cation } \\
\text { exchange }^{d}\end{array}$ & $\begin{array}{c}\text { DUR-02-598 } \\
(1994)\end{array}$ \\
\hline & Alkalinity & 0 & 690 & 1330 & 272 & 640 \\
\hline & Calcium & NA & 150 & 440 & 390 & 420 \\
\hline & Manganese & 200 & 2.2 & NA & 7.0 & 2.3 \\
\hline & $\mathrm{pH}$ & 0.8 & 7.4 & 7.3 & 7.0 & 7.3 \\
\hline & Sodium & 16,000 & 14,370 & 13,200 & 360 & 3300 \\
\hline & Sulfate & 66,000 & 27,500 & 29,000 & 2,500 & 7900 \\
\hline 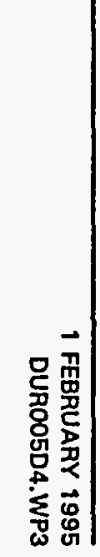 & NA - not a & & & & & \\
\hline
\end{tabular}




\section{Mill tailings area}

The primary sources of ground water contamination in the mill tailings area were the large and small tailings piles (see Figure 3.2). Surface remediation removed these sources of contamination. Using constituents that are known to be related to uranium processing at the site, it appears that contamination has been slowly moving downgradient in two primary plumes, one associated with each tailings pile. For instance, Figure 3.4 is a November 1983 spatial distribution map for sulfate. There is minor variability, related to remediation, but overall, contamination is increasing in monitor well DUR-01-617 and decreasing in monitor well DUR-01-612. Monitor well DUR-01-612 currently has the highest levels of most constituents (Table 3.2). It can be predicted that uranium processing constituents will continue to decline in monitor well DUR-01-612 while the first plume moves downgradient and into the Animas River. Contaminants will increase in monitor well DUR-01-617, then decline as the second plume reaches the well and then moves on past. Early contamination in monitor well DUR-01-622 has apparently been almost completely flushed out.

The mill tailings area is complicated by the presence of vitreous lead smelter slag underlying much of the southern half of the mill tailings area. At the river's edge, slag from the old lead smelter is approximately $40 \mathrm{ft}(12 \mathrm{~m})$ thick.

Elements commonly associated with lead ore, in addition to lead, are cadmium, molybdenum, selenium, and zinc (Evans, 1987). Thus, concentrations of these elements could be high in the southern part of the mill tailings area for reasons that are unrelated to uranium processing at the site.

Another complicating factor in the mill tailings area is that all downgradient monitor wells are completed in alluvial gravel and none are in the clay-rich colluvium. Large areas of the former tailings piles were underlain by colluvial materials. Tailings seepage in the colluvial material will likely move more slowly than ground water in the alluvial gravel. Thus, while contamination in the alluvial gravel moves downgradient, colluvial materials will continue to supply small amounts of contamination to ground water in the gravel in the areas of the former tailings piles.

After the extent of contamination was determined using a limited set of constituents indicative of contamination (sulfate, vanadium, and uranium), filtered and unfiltered water quality data collected between 1990 and 1994 were used to identify the full suite of constituents elevated above background levels in contaminated portions of the aquifer underlying the mill tailings area. The evaluation involved comparing water quality data from background wells DUR-01-629 and -658 to contaminated ground water data from plume wells DUR-01-612 and -617 . Table 3.2 summarizes the water quality data used in this evaluation.

Constituents for which adequate data exist for an inferential statistical comparison of background to plume concentrations were cadmium, calcium, chloride, iron, magnesium, manganese, molybdenum, nitrate, potassium, 


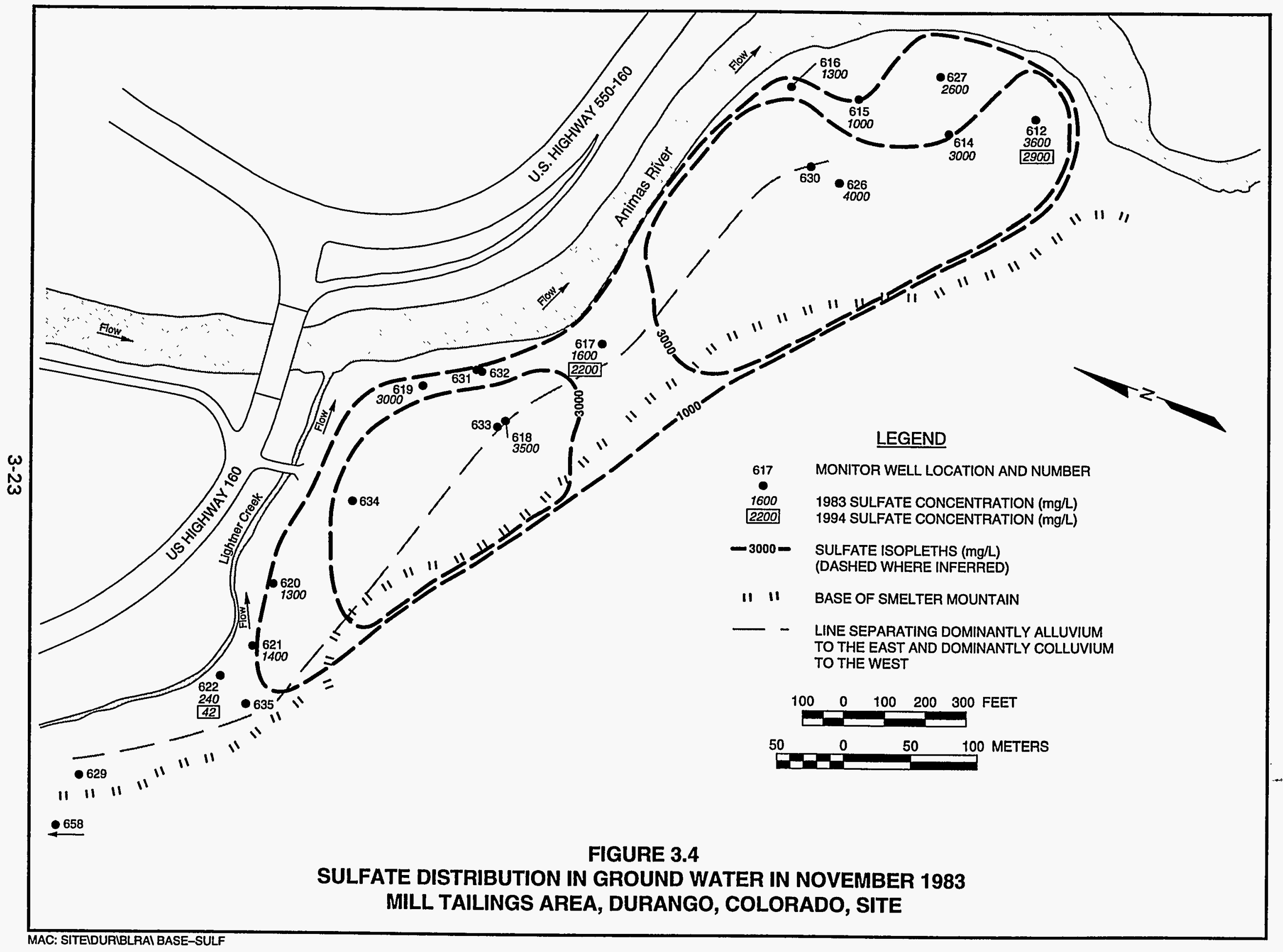


selenium, sodium, sulfate, uranium, vanadium, and zinc. A nonparametric

Wilcoxon Rank-Sum test was first performed to determine whether concentrations in plume wells DUR-01-612 and -617 differ from each other at a 0.10 level of significance. If so, the water quality data from the more contaminated well were used in the comparison to background levels; otherwise, the data from the two plume wells were combined for the comparison. Based on a Wilcoxon Rank-Sum test, all the constituents listed above except iron were determined to be above background levels at the 0.10 level of significance (TAC, 1995). Constituent concentrations observed in the more contaminated well were used to assess risk and are presented in Table 3.2.

Some constituents that were detected at least once in the contaminated ground water were not subjected to statistical testing. These constituents were either not analyzed for in background wells, or there were insufficient numbers of measurements above detection limits to allow for quantitative evaluation. These constituents were ammonium, antimony, barium, fluoride, lead, silica, silver, strontium, and tin. They were included in a screening of contaminants of potential concern. In addition, radiochemical constituents (lead-210, polonium-210, radium-226, and thorium-230) were retained for evaluation because they are progeny of natural uranium.

\section{Raffinate ponds area}

Several constituents can be used to determine the extent of ground water contamination at the raffinate ponds area, including chloride, sulfate, sodium, uranium, and manganese. Of these, chloride is the best indicator because it is 1) nonreactive in ground water, 2) present in the raffinate at relatively high concentrations (greater than $1000 \mathrm{mg} / \mathrm{L}$ ), and 3) low in background (less than $100 \mathrm{mg} / \mathrm{L})$.

Figure 3.5 shows the concentrations of chloride using chloride in excess of 100 $\mathrm{mg} / \mathrm{L}$ as an indicator of contamination. In general, recent data demonstrate that areas upgradient of the raffinate ponds area (monitor wells DUR-02-607, -599 , and -600 ) are, at present, not obviously contaminated. However, historical data for monitor well DUR-02-607 (a relatively shallow well completed in both alluvium and bedrock) demonstrate that this area was contaminated in the past but has been flushed.

There are not sufficient data to determine the extent of contamination crossgradient and downgradient of the site. Older data from a decommissioned well (DUR-02-601) demonstrate that contamination extended from the southern ponds area (near monitor well DUR-02-607) east toward the Animas River. Recently, slightly elevated concentrations of chloride $(160 \mathrm{mg} / \mathrm{L})$ in well DUR-02-595 suggest that contamination also extends north of the ponds area to the Animas River. Data to determine the extent of contamination east and downgradient of the ponds area are limited; contamination extends at least to the eastern property boundary, as evidenced by wells DUR-02-602, -628 , and 


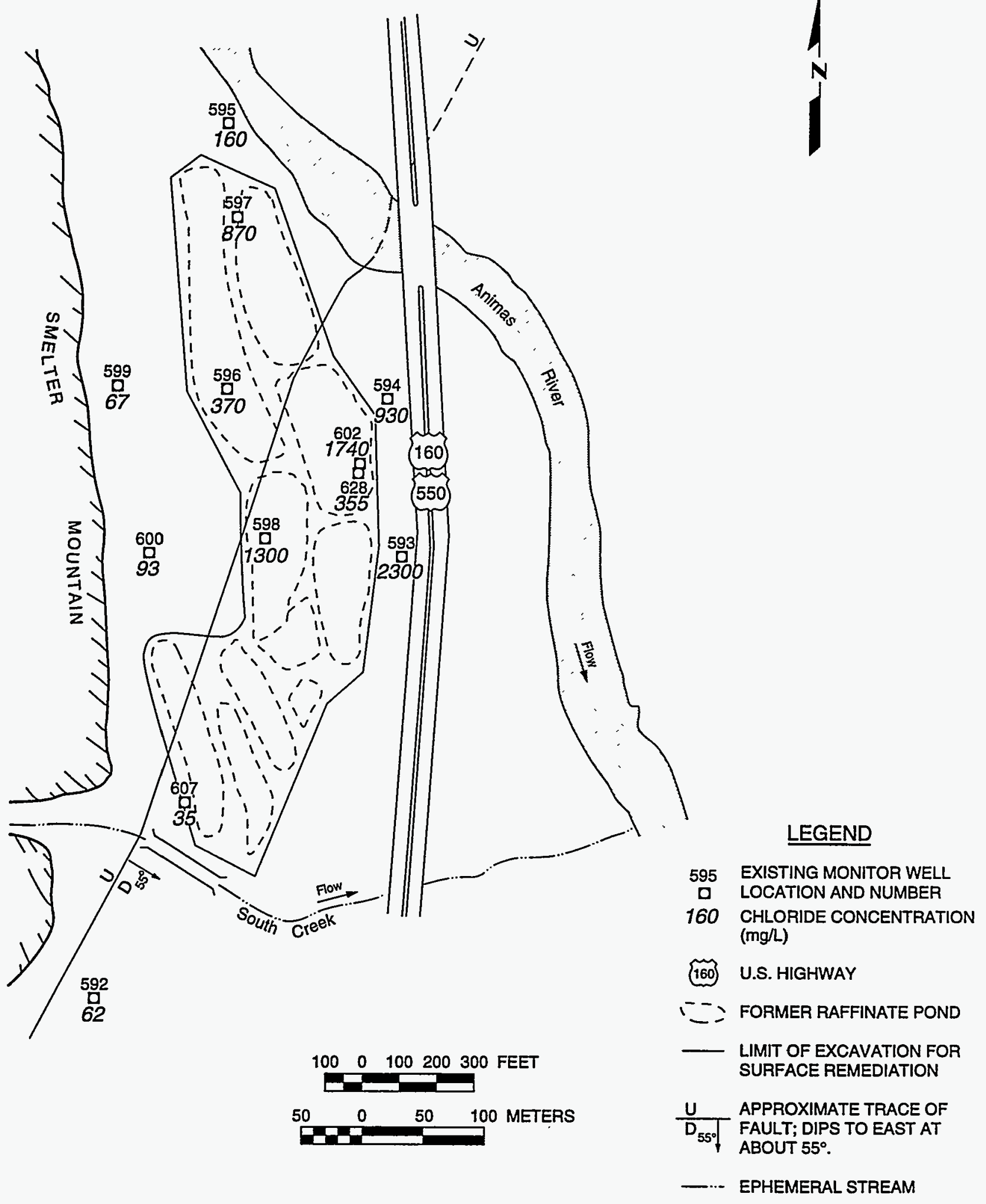

FIGURE 3.5

DISTRIBUTION OF CHLORIDE IN GROUND WATER, RAFFINATE PONDS AREA NOVEMBER 1993 AND JANUARY 1994 DATA DURANGO, COLORADO, SITE 
-593. There are no wells in the area between the site boundary and the Animas River.

The vertical extent of contamination is also not known. Older data (1982 to 1985 ) indicate that contamination extended to at least a depth of between 124 and $138 \mathrm{ft}(37.8$ and $42.1 \mathrm{~m})$ below land surface in the fault (in monitor well DUR-02-624), and to at least 65 to $80 \mathrm{ft}(20$ to $24 \mathrm{~m}$ ) in the bedrock (in monitor well DUR-02-610) (Figure 3.3).

Reactions of the raffinate with minerals in the aquifer have resulted in decreased concentrations of contaminants (relative to the original raffinate) in ground water beneath the former raffinate ponds area. While the raffinate was highly acidic ( $\mathrm{pH}$ of 0.8 ), no acidic ground waters occur at the raffinate ponds area. It is clear that raffinate was neutralized upon seeping into the alluvium and bedrock by reaction with carbonate minerals, such as calcite. Modeling of the reaction using the computer program PHREEQE (Parkhurst et al., 1980) indicates that neutralization would have the effect of increasing the $\mathrm{pH}$ to a value of about 7.3 and decreasing the concentrations of sulfate, iron, and manganese (Table 3.5) (TAC, 1995).

In the past, the greatest amount of contamination in the raffinate ponds area occurred within the alluvium and fault, with contamination extending to the bedrock to a lesser extent. However, processes of cation exchange, gypsum precipitation, and adsorption greatly reduced the amount of contamination in ground water within the bedrock aquifers when compared to ground water in the surficial deposits and fault.

Contaminated ground water found in the alluvium, fault, and shallow bedrock has relatively high concentrations of sulfate, sodium, and trace metals. Within the deeper bedrock, contaminated ground water has lower concentrations of these constituents (Tables 3.6 and 3.7). The fact that chloride concentrations are similar in both shallow and deeper ground water demonstrates that reactions with the aquifer matrix have had the effect of substantially decreasing concentrations of both major and minor constituents. In addition, dilution has caused concentrations of chloride and other constituents to decrease in wells located near the upgradient and crossgradient edges of the raffinate ponds area (wells DUR-02-607, -596, -597, and -595 in Figure 3.5).

Surface remediation removed large amounts of contaminated surficial deposits (to a depth of up to $20 \mathrm{ft}[6 \mathrm{~m}]$ ) and removed potential sources of continued ground water contamination. At present, there is very little ground water remaining in the alluvium (Figure 2.7), and what has been sampled (monitor wells DUR-02-607 and DUR-02-628) has been diluted, probably by surface recharge. Thus, at present, most contaminated ground water at the site is in the bedrock and fault. The greatest amount of contamination has been found in three wells: a shallow bedrock well (DUR-02-593), a deeper bedrock well (DUR02-602), and a fault well (DUR-02-598). These wells are used to evaluate risks. 


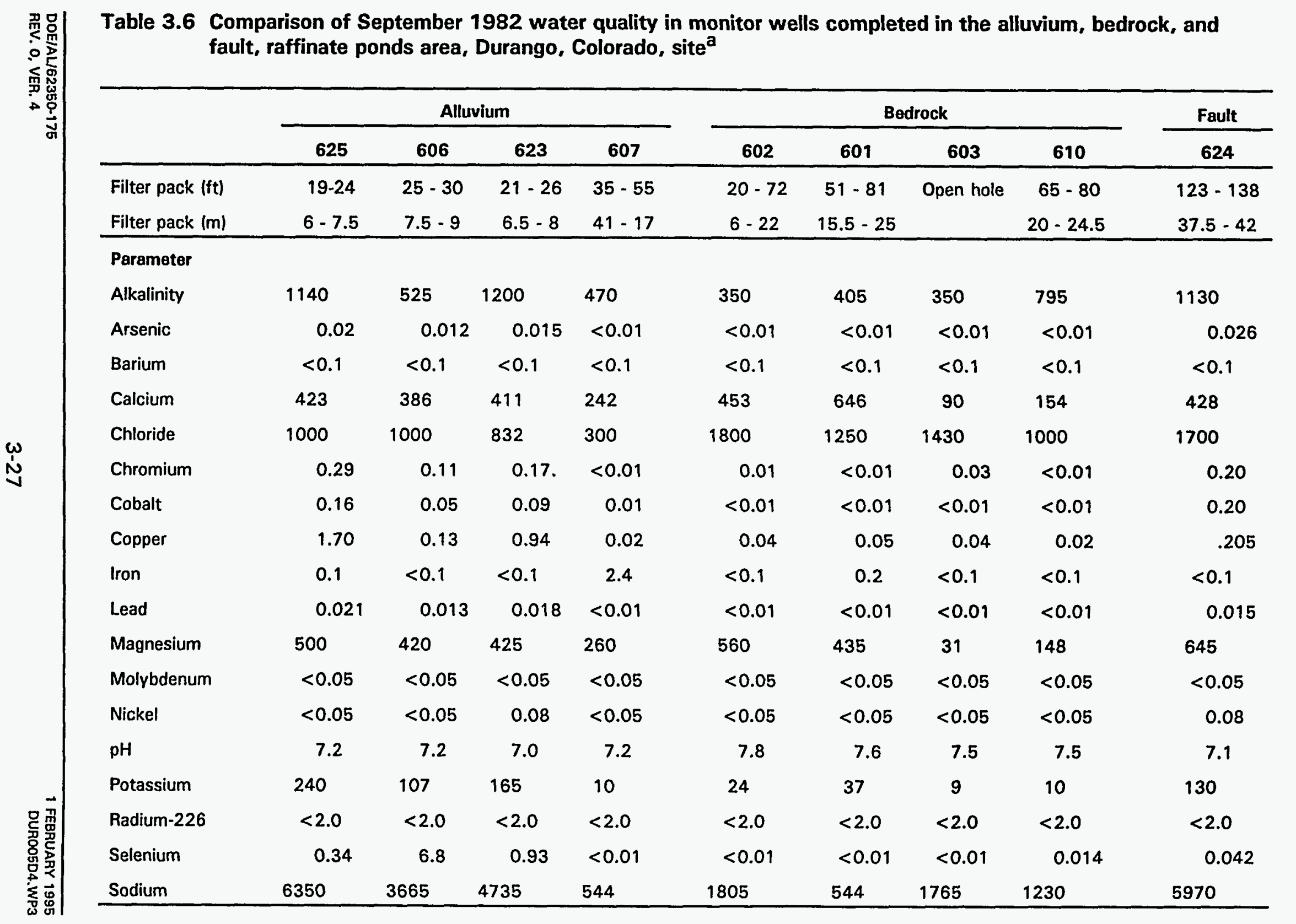




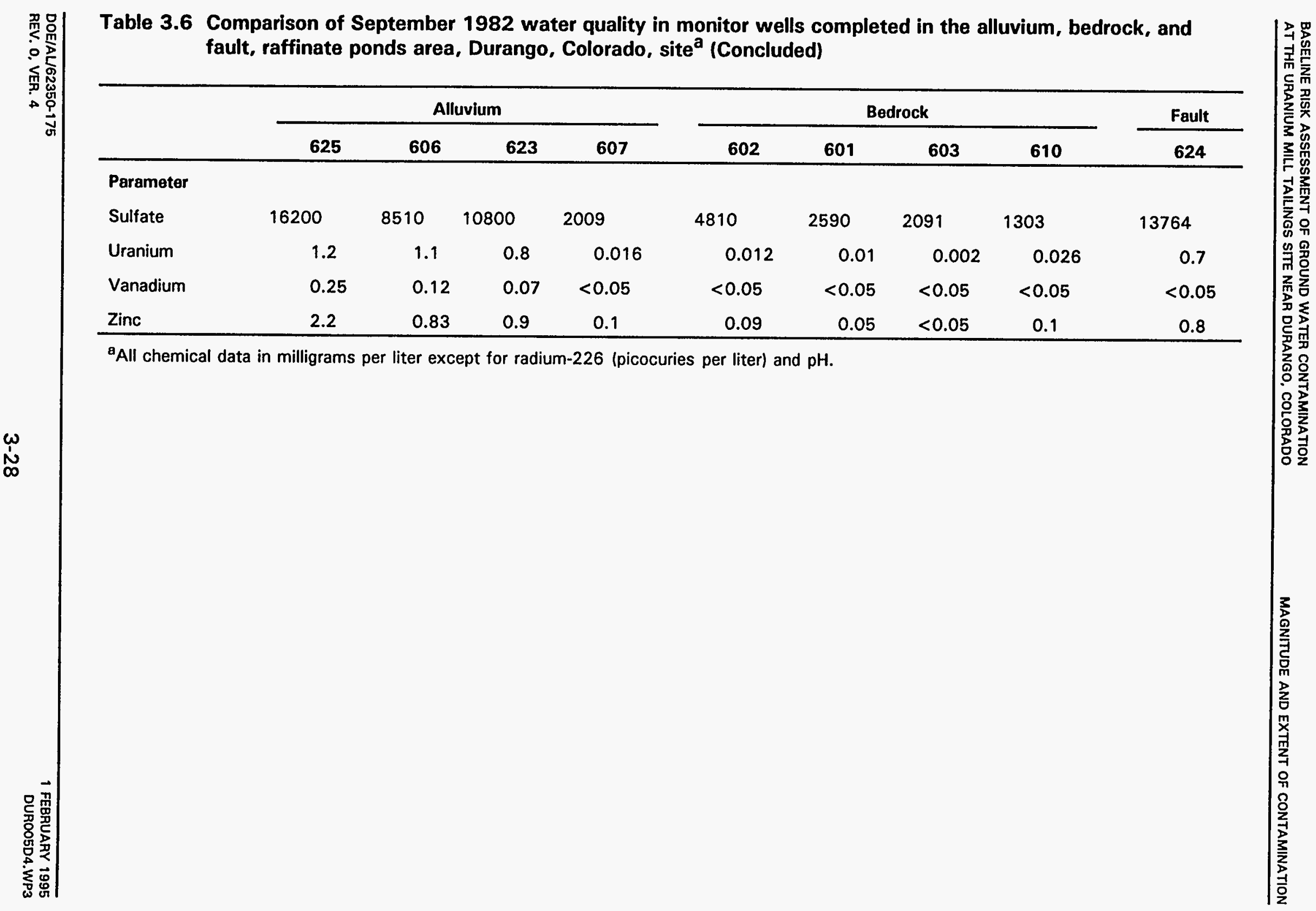




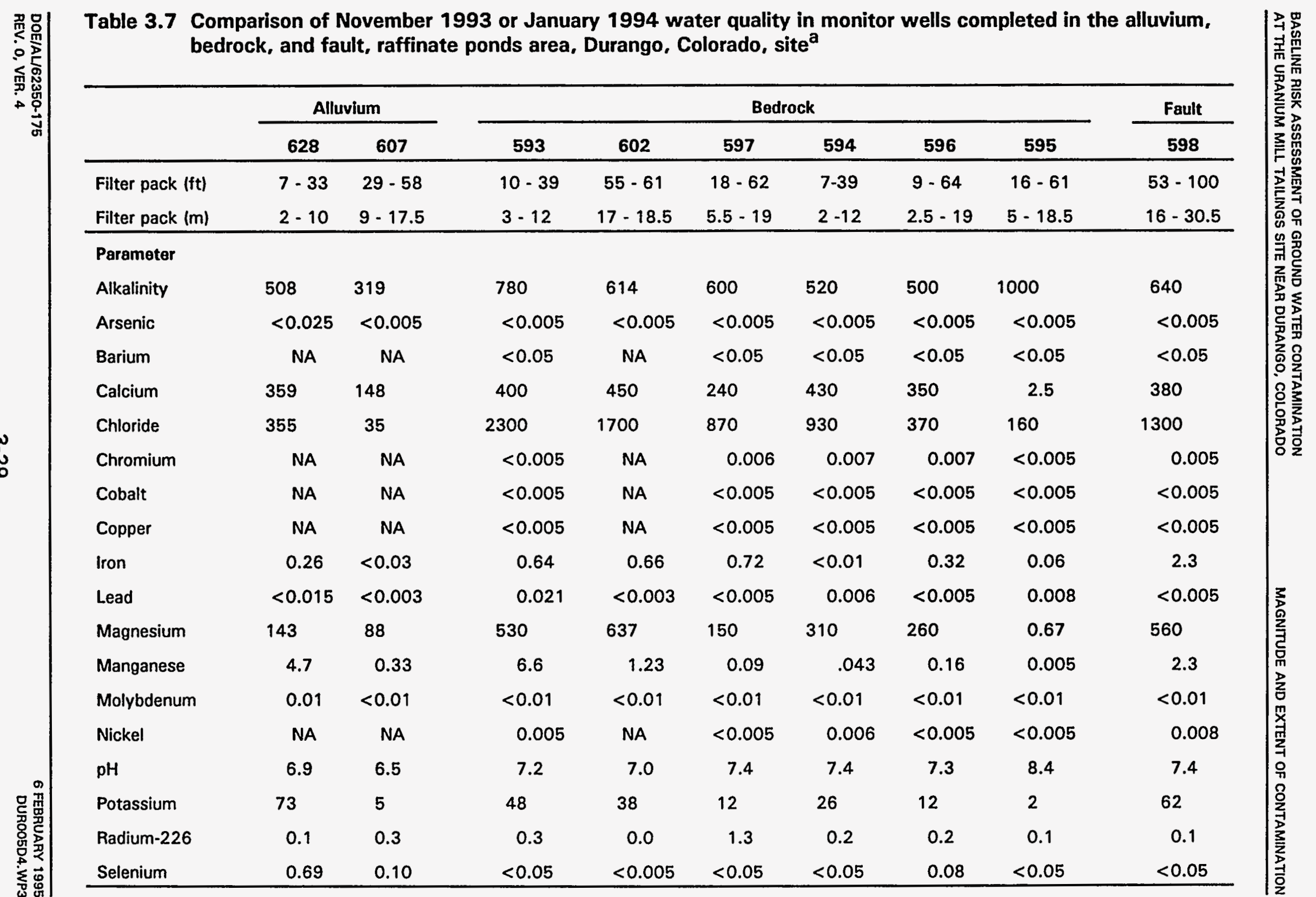




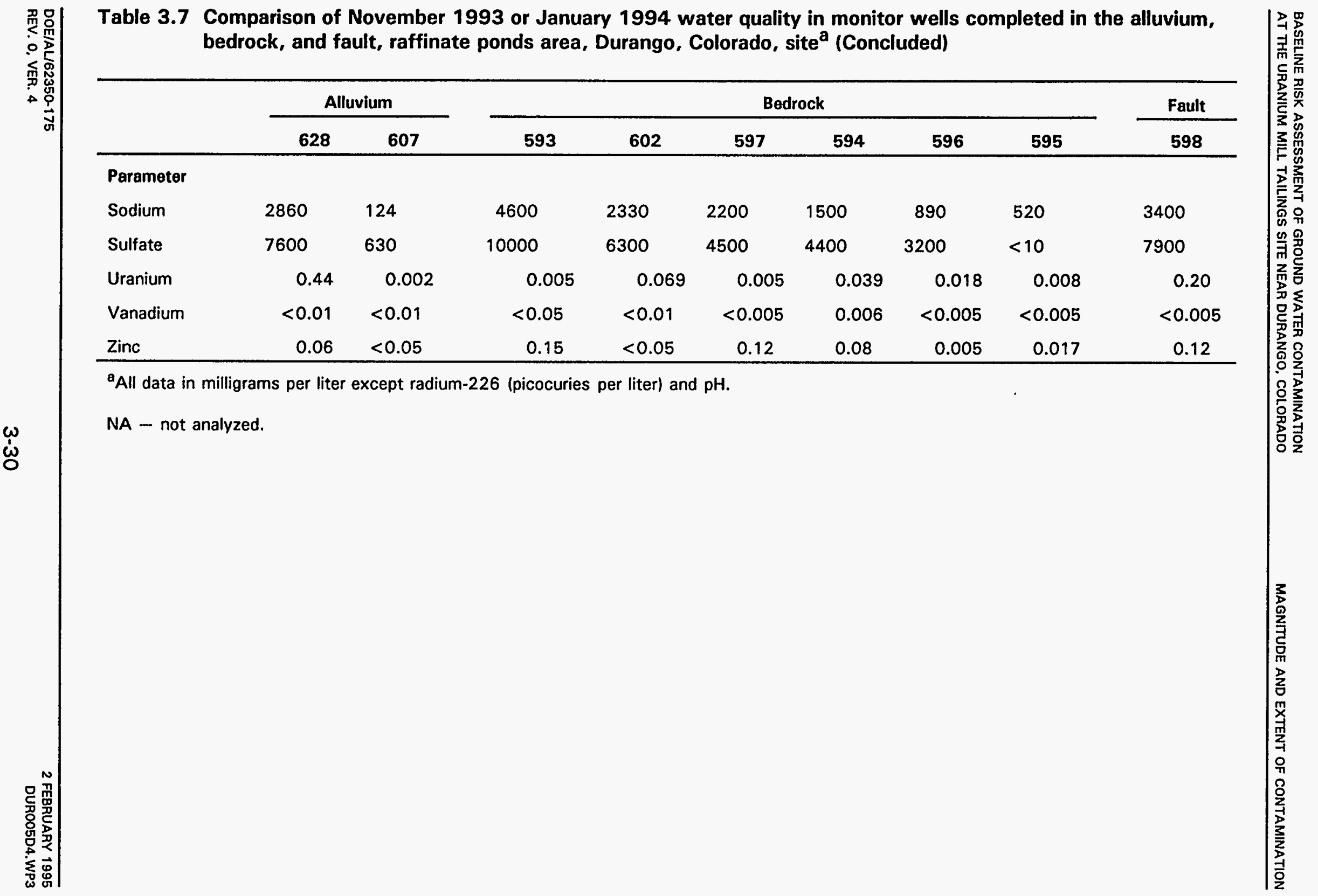


After the extent of contamination was determined using a limited set of constituents indicative of contamination (chloride, sulfate, manganese, and uranium), filtered and unfiltered water quality data collected between 1990 and 1994 were used to identify the full suite of constituents elevated above background levels in contaminated portions of the aquifer underlying the raffinate ponds area. The evaluation involved comparing water quality data from background well DUR-02-592 to contaminated ground water from wells DUR-02-593, -598 , and -602 . Table 3.8 summarizes the water quality data used in this evaluation.

Adequate data exist for an inferential statistical comparison of background concentrations to plume concentrations for calcium, iron, magnesium, manganese, potassium, sodium, sulfate, uranium, and zinc. For these constituents, the nonparametric Wilcoxon Rank-Sum test was used to compare concentration levels in well DUR-02-592 to those in each of the three contaminated plume wells DUR-02-593, -598 , and -602 . All constituents tested were determined to be above background levels at the 0.10 level of significance or less (TAC, 1995). A follow-up multiple comparison of contaminant levels in the three plume wells was then performed to identify the well or wells with the highest average concentrations. Levels observed in the most contaminated well(s) were used to assess risk and are presented in Table 3.8.

Some constituents that were detected at least once in the contaminated ground water were not subjected to statistical testing. These constituents either were not analyzed for in background wells, or there were insufficient numbers of measurements above detection limits to allow for quantitative evaluation. These constituents were ammonium, antimony, arsenic, barium, cadmium, chromium, cobalt, copper, fluoride, lead, molybdenum, nickel, selenium, silica, strontium, sulfide, thallium, tin, and vanadium. They were included in a screening of contaminants of potential concern. In addition, radiochemical constituents (lead-210, polonium-210, radium-226, and thorium-230) were retained for evaluation because they are progeny of natural uranium.

\subsection{CONTAMINANTS OF POTENTIAL CONCERN}

The results of analyses in Sections 3.1 and 3.2 were used to compile a list of contaminants of potential concern for the assessment of risks to human health and the environment at the Durango site. The constituents listed in column one of Table 3.9 for the mill tailings area and Table 3.10 for the raffinate ponds area are either 1 ) elevated above background levels at the 0.10 level of significance or less, or 2) detected at least once in contaminated ground water at the site, but data are insufficient to conduct a statistical test.

These constituents were screened for their potential to affect human health. The screening was based on the range of observed concentrations in filtered and unfiltered ground water samples between May 1990 and June 1994. Data obtained from sampling rounds back to 1987 were also examined for 


\begin{tabular}{|c|c|c|c|c|c|c|c|}
\hline \multirow[b]{3}{*}{ Constituent } & \multirow[b]{3}{*}{ Well ID } & \multicolumn{4}{|c|}{ Filtered samples } & \multicolumn{2}{|c|}{ Unfiltered samples } \\
\hline & & \multirow{2}{*}{$\begin{array}{c}\text { Frequency } \\
\text { of } \\
\text { detectionc }\end{array}$} & Minimum & Median ${ }^{d}$ & Maximum $^{\theta}$ & \multirow{2}{*}{$\begin{array}{c}\text { Frequency } \\
\text { of } \\
\text { detection }^{c}\end{array}$} & \multirow{2}{*}{$\begin{array}{c}\text { Maximum observed } \\
\text { value } \\
\text { (mg/L) }\end{array}$} \\
\hline & & & & (mg/L) & & & \\
\hline \multicolumn{8}{|l|}{ Inorganics } \\
\hline \multirow[t]{2}{*}{ Aluminum } & Bkg 592 & $0 / 4$ & $<0.1$ & $<0.1$ & $<0.1$ & NA & NA \\
\hline & Plume & $0 / 11$ & $<0.05$ & $<0.1$ & $<1.0$ & NA & NA \\
\hline \multirow[t]{2}{*}{ Ammonium $^{f}$} & Bkg 592 & NA & NA & NA & NA & NA & NA \\
\hline & Plume (602) & $2 / 2$ & 3.1 & 3.2 & 3.3 & NA & NA \\
\hline \multirow[t]{2}{*}{ Antimony ${ }^{f}$} & Bkg 592 & NA & NA & NA & NA & NA & NA \\
\hline & Plume (602) & $1 / 4$ & $<0.003$ & $<0.025$ & 0.166 & $1 / 1$ & 0.196 \\
\hline \multirow[t]{2}{*}{ Arsenic } & Bkg 592 & $0 / 4$ & $<0.005$ & $<0.005$ & $<0.005$ & NA & NA \\
\hline & Plume & $1 / 17$ & $<0.005$ & $<0.01$ & 0.04 & $1 / 4$ & 0.04 \\
\hline \multirow[t]{2}{*}{ Barium } & Bkg 592 & $1 / 4$ & $<0.05$ & $<0.05$ & 0.06 & NA & NA \\
\hline & Plume & $1 / 13$ & $<0.01$ & $<0.05$ & 0.05 & $1 / 1$ & $<0.10$ \\
\hline \multirow[t]{2}{*}{ Beryllium $f$} & Bkg 592 & NA & NA & NA & NA & NA & NA \\
\hline & Plume (602) & $0 / 3$ & $<0.005$ & $<0.01$ & $<0.01$ & $0 / 1$ & $<0.01$ \\
\hline \multirow[t]{2}{*}{ Cadmium } & Bkg 592 & $0 / 4$ & $<0.0001$ & $<0.003$ & $<0.005$ & NA & NA \\
\hline & Plume & $3 / 17$ & $<0.0001$ & $\mathbf{g}$ & 0.0009 & $0 / 4$ & $<0.001$ \\
\hline \multirow[t]{2}{*}{ Calcium } & Bkg 592 & $4 / 4$ & 110 & 115 & 120 & NA & NA \\
\hline & Plume & $17 / 17$ & 339 & 416 & 491 & $4 / 4$ & 475 \\
\hline
\end{tabular}




\begin{tabular}{|c|c|c|c|c|c|c|c|}
\hline \multirow{4}{*}{ 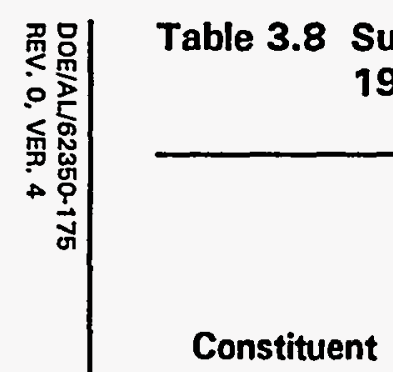 } & \multicolumn{7}{|c|}{$\begin{array}{l}\text { ummary of ground water quality data at the raffinate ponds area at Durango, Colorado, May } 1990 \text { - June } \\
994 \text { (filtered samples, except as noted) }{ }^{a} \text { (Continued) }\end{array}$} \\
\hline & & \multicolumn{4}{|c|}{ Filtered samples } & \multicolumn{2}{|c|}{ Unfiltered samples } \\
\hline & & \multirow{2}{*}{$\begin{array}{c}\text { Frequency } \\
\text { of } \\
\text { detection }\end{array}$} & Minimum & Mediand & Maximum $^{\theta}$ & \multirow{2}{*}{$\begin{array}{c}\text { Frequency } \\
\text { of } \\
\text { detectionc }\end{array}$} & \multirow{2}{*}{$\begin{array}{c}\text { Maximum observed } \\
\text { value } \\
\text { (mg/L) }\end{array}$} \\
\hline & Well ID & & & (mg/L) & & & \\
\hline \multicolumn{8}{|l|}{ Inorganics } \\
\hline \multirow[t]{2}{*}{ Chloride } & Bkg 592 & $4 / 4$ & 62 & 66 & 69 & NA & NA \\
\hline & Plume & $15 / 15$ & 1100 & 2000 & 2400 & $5 / 5$ & 2380 \\
\hline \multirow[t]{2}{*}{ Chromium } & Bkg 592 & $0 / 4$ & $<0.005$ & $<0.005$ & $<0.005$ & NA & NA \\
\hline & Plume & $2 / 13$ & $<0.005$ & $\mathbf{g}$ & 0.006 & $0 / 1$ & $<0.01$ \\
\hline \multirow[t]{2}{*}{ Cobalt } & Bkg 592 & $0 / 4$ & $<0.005$ & $<0.005$ & $<0.005$ & NA & NA \\
\hline & Plume & $1 / 11$ & $<0.005$ & $<0.005$ & 0.005 & $0 / 1$ & 0.05 \\
\hline \multirow[t]{2}{*}{ Copper } & Bkg 592 & $0 / 4$ & $<0.005$ & $<0.005$ & $<0.005$ & NA & NA \\
\hline & Plume & $2 / 13$ & $<0.005$ & $<0.01$ & 0.011 & $0 / 1$ & $<0.02$ \\
\hline \multirow[t]{2}{*}{ Cyanide $^{f}$} & Bkg 592 & NA & NA & NA & NA & NA & NA \\
\hline & Plume (602) & $0 / 3$ & $<0.01$ & $<0.01$ & $<0.01$ & NA & NA \\
\hline \multirow[t]{2}{*}{ Fluoride $^{f}$} & Bkg 592 & NA & NA & NA & NA & NA & NA \\
\hline & Plume (602) & $5 / 5$ & $<0.1$ & 0.2 & 0.4 & $1 / 1$ & 0.2 \\
\hline \multirow[t]{2}{*}{ Iron $^{h}$} & Bkg 592 & $4 / 4$ & 0.02 & 0.02 & 0.02 & NA & NA \\
\hline & Plume (598) & $6 / 6$ & 1.8 & 2.4 & 2.5 & $5 / 5$ & 2.96 \\
\hline \multirow[t]{2}{*}{ Lead } & Bkg 592 & $0 / 4$ & $<0.001$ & $<0.005$ & $<0.005$ & NA & NA \\
\hline & Plume & $2 / 17$ & $<0.002$ & $<0.021$ & 0.070 & $0 / 4$ & $<0.01$ \\
\hline
\end{tabular}




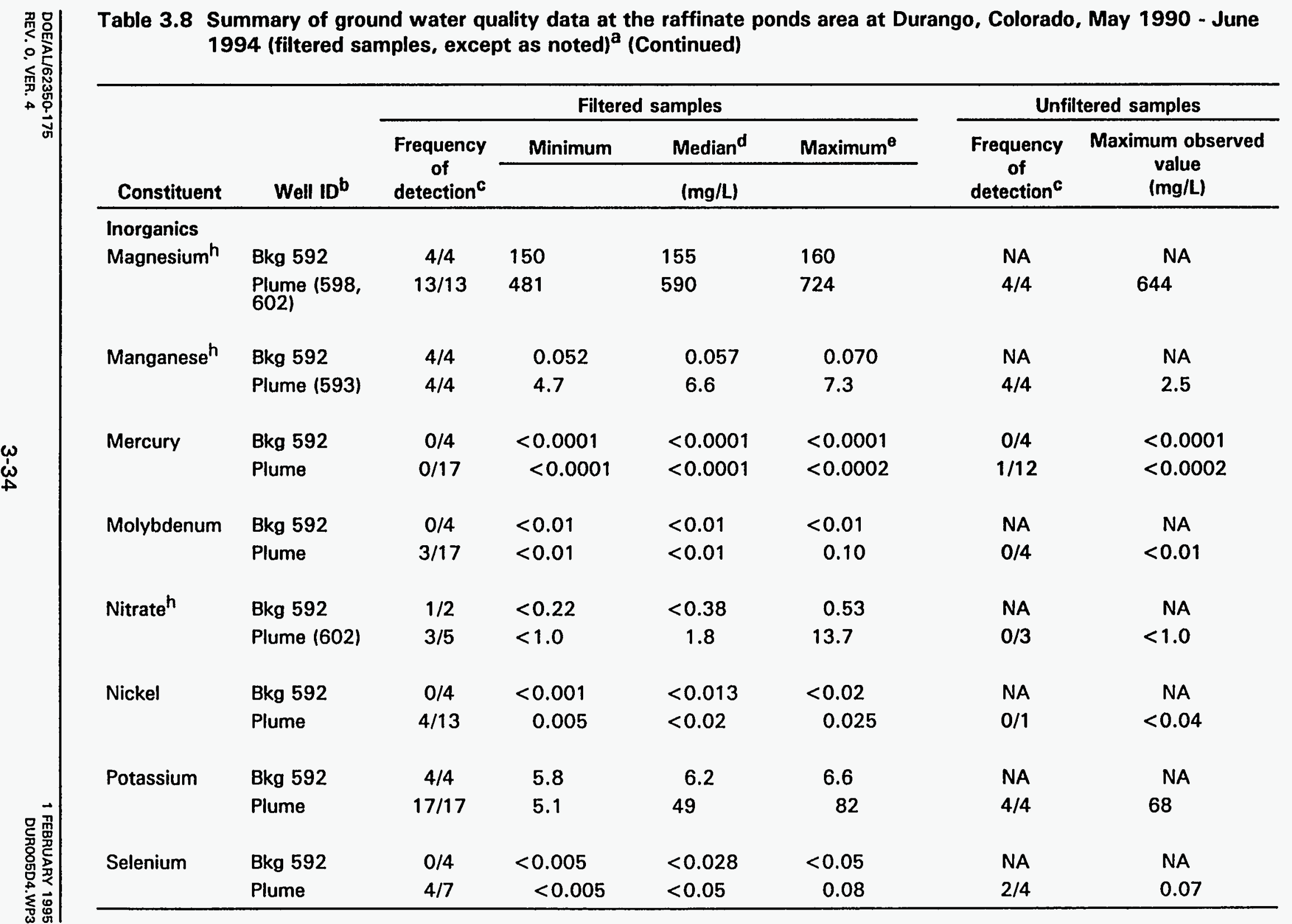




\begin{tabular}{|c|c|c|c|c|c|c|c|}
\hline \multirow{4}{*}{ 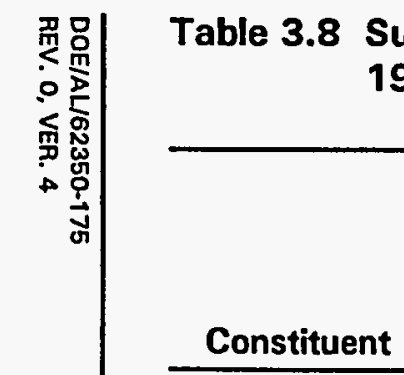 } & \multicolumn{7}{|c|}{$\begin{array}{l}\text { ummary of ground water quality data at the raffinate ponds area at Durango, Colorado, May } 1990 \text { - June } \\
994 \text { (filtered samples, except as noted) }^{\text {a }} \text { (Continued) }\end{array}$} \\
\hline & & \multicolumn{4}{|c|}{ Filtered samples } & \multicolumn{2}{|c|}{ Unfiltered samples } \\
\hline & & \multirow{2}{*}{$\begin{array}{c}\text { Frequency } \\
\text { of } \\
\text { detection }\end{array}$} & Minimum & Mediand & Maximum ${ }^{\theta}$ & \multirow{2}{*}{$\begin{array}{c}\text { Frequency } \\
\text { of } \\
\text { detection }\end{array}$} & \multirow{2}{*}{$\begin{array}{c}\text { Maximum observed } \\
\text { value } \\
\text { (mg/L) }\end{array}$} \\
\hline & Well ID & & & (mg/L) & & & \\
\hline \multicolumn{8}{|l|}{ Inorganics } \\
\hline \multirow[t]{2}{*}{ Silica $^{f}$} & Bkg 592 & $4 / 4$ & 8.5 & 8.6 & 9.0 & NA & NA \\
\hline & Plume (602) & $2 / 2$ & 23.1 & 24.0 & 24.9 & $4 / 4$ & 22.8 \\
\hline \multirow[t]{2}{*}{ Silver ${ }^{f}$} & Bkg 592 & NA & NA & NA & NA & NA & NA \\
\hline & Plume (602) & $0 / 5$ & $<0.01$ & $<0.01$ & $<0.01$ & $0 / 1$ & $<0.01$ \\
\hline \multirow[t]{2}{*}{ Sodium ${ }^{h}$} & Bkg 592 & $4 / 4$ & 240 & 245 & 250 & NA & NA \\
\hline & Plume (593) & $4 / 4$ & 3500 & 4200 & 4600 & $4 / 4$ & 3370 \\
\hline \multirow[t]{2}{*}{ Strontium ${ }^{f}$} & Bkg 592 & NA & NA & NA & NA & NA & NA \\
\hline & Plume (602) & $3 / 3$ & 7.0 & 10 & 11 & NA & NA \\
\hline \multirow[t]{2}{*}{ Sulfate ${ }^{h}$} & Bkg 592 & $4 / 4$ & 560 & 680 & 680 & NA & NA \\
\hline & $\begin{array}{l}\text { Plume (593, } \\
598)\end{array}$ & $9 / 9$ & 7310 & 8600 & 10,000 & $4 / 4$ & 7740 \\
\hline \multirow[t]{2}{*}{ Sulfide $^{f}$} & Bkg 592 & NA & NA & NA & NA & NA & NA \\
\hline & Plume (602) & $1 / 3$ & $<0.1$ & $<0.1$ & 0.3 & NA & NA \\
\hline \multirow{2}{*}{ Thallium $^{f}$} & Bkg 592 & NA & NA & NA & NA & NA & NA \\
\hline & $\begin{array}{l}\text { Plume (598, } \\
602 \text { ) }\end{array}$ & $2 / 5$ & $<0.005$ & $<0.025$ & 0.06 & $0 / 3$ & $<0.01$ \\
\hline
\end{tabular}




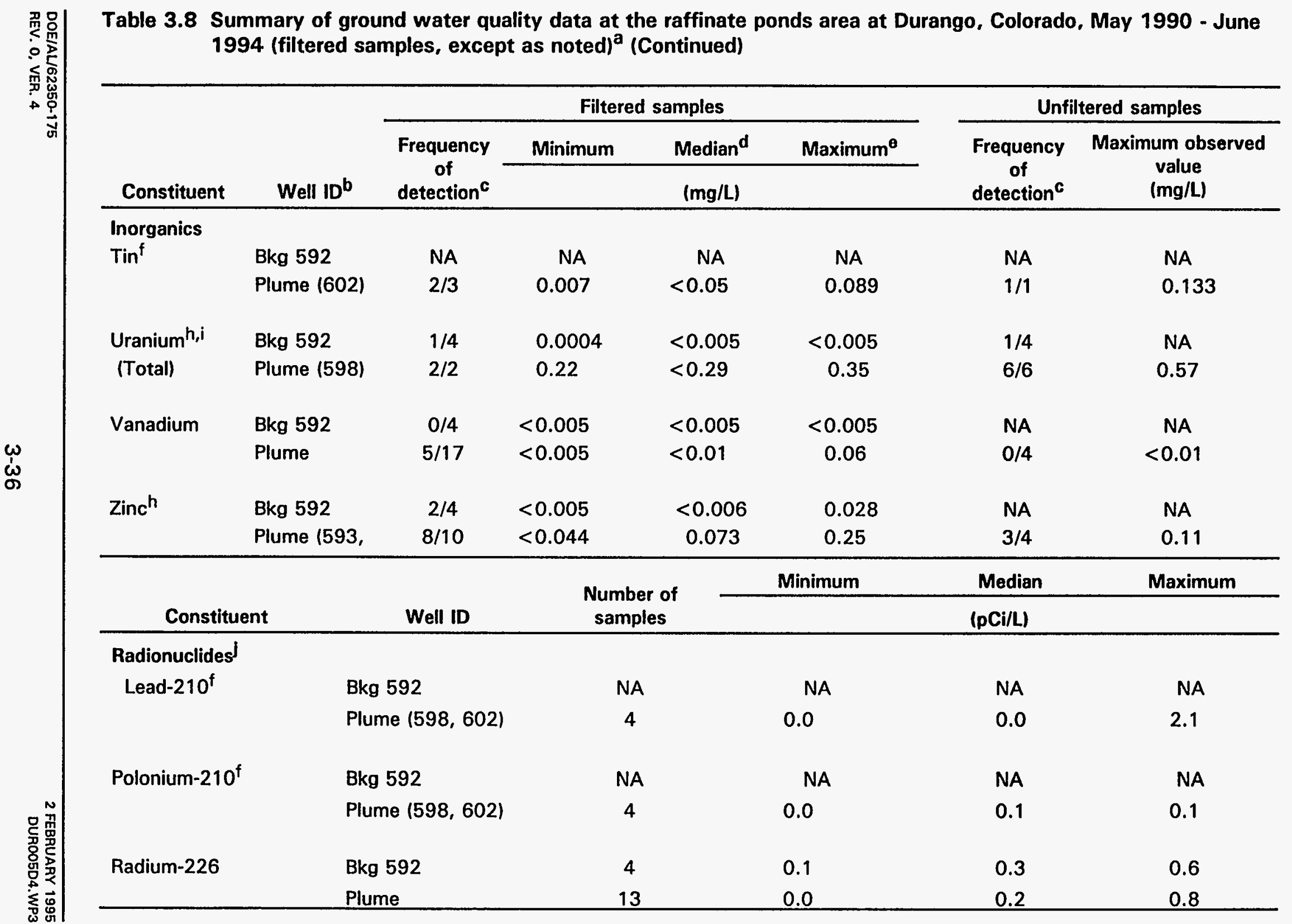




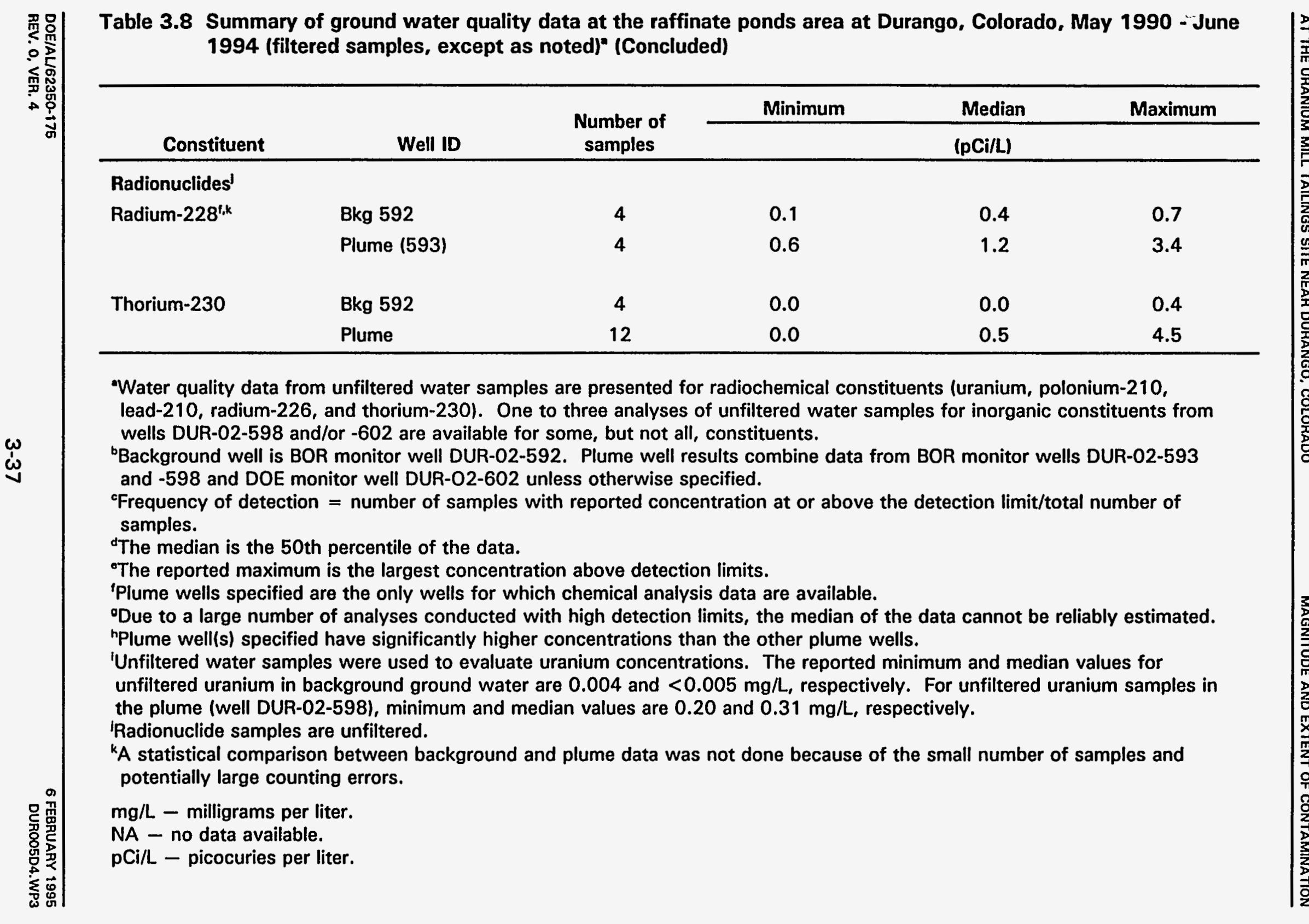


Table 3.9 Contaminants of potential concern for the mill tailings area, Durango, Colorado, site $^{a}$

\begin{tabular}{|c|c|c|c|}
\hline $\begin{array}{c}\text { Contaminants } \\
\text { exceeding } \\
\text { background levels } \\
\end{array}$ & $\begin{array}{l}\text { Contaminants in } \\
\text { nutritional range }\end{array}$ & $\begin{array}{l}\text { Contaminants of low } \\
\text { toxic potency and/or } \\
\text { high dietary range }\end{array}$ & $\begin{array}{l}\text { Contaminants of } \\
\text { potential concern }\end{array}$ \\
\hline Ammonium & Calcium & Ammonium & Antimony \\
\hline Antimony & Fluoride & Barium & Cadmium \\
\hline Barium & Potassium & Chloride & Lead \\
\hline Cadmium & Zinc & Magnesium & Manganese \\
\hline Calcium & & Nitrate & Molybdenum \\
\hline Chloride & & Silica & Selenium \\
\hline Fluoride & & Silver & Sodium \\
\hline Lead & & Strontium & Sulfate \\
\hline Magnesium & & Tin & Uranium \\
\hline Manganese & & & Vanadium \\
\hline \multicolumn{4}{|l|}{ Molybdenum } \\
\hline \multicolumn{4}{|l|}{ Nitrate } \\
\hline \multicolumn{4}{|l|}{ Potassium } \\
\hline \multicolumn{4}{|l|}{ Selenium } \\
\hline \multicolumn{4}{|l|}{ Silica } \\
\hline \multicolumn{4}{|l|}{ Silver } \\
\hline \multicolumn{4}{|l|}{ Sodium } \\
\hline \multicolumn{4}{|l|}{ Strontium } \\
\hline \multicolumn{4}{|l|}{ Sulfate } \\
\hline \multicolumn{4}{|l|}{ Tin } \\
\hline \multicolumn{4}{|l|}{ Uranium } \\
\hline \multicolumn{4}{|l|}{ Vanadium } \\
\hline Zinc & & & \\
\hline
\end{tabular}

${ }^{a}$ The screening process starts with the first column; constituents listed in the second and third columns are subtracted from the list of constituents in the first column; the remaining constituents form the list shown in the last column. 
Table 3.10 Contaminants of potential concern for the raffinate ponds area, Durango, Colorado, site ${ }^{a}$

\begin{tabular}{|c|c|c|c|}
\hline $\begin{array}{c}\text { Contaminants } \\
\text { exceeding } \\
\text { background levels }\end{array}$ & $\begin{array}{l}\text { Contaminants in } \\
\text { nutritional range }\end{array}$ & $\begin{array}{l}\text { Contaminants of low } \\
\text { toxic potency and/or } \\
\text { high dietary range }\end{array}$ & $\begin{array}{l}\text { Contaminants of } \\
\text { potential concern }\end{array}$ \\
\hline Ammonium & Calcium & Ammonium & Antimony \\
\hline Antimony & Chromium & Cobalt & Arsenic \\
\hline Arsenic & Copper & Magnesium & Cadmium \\
\hline Cadmium & Fluoride & Nickel & Chloride \\
\hline Calcium & Iron & Silica & Lead \\
\hline Chloride & Potassium & Strontium & Manganese \\
\hline Chromium & Zinc & Sulfide & Molybdenum \\
\hline Cobalt & & Tin & Selenium \\
\hline Copper & & Vanadium & Sodium \\
\hline Fluoride & & & Sulfate \\
\hline Iron & & & Thallium \\
\hline Lead & & & Uranium \\
\hline \multicolumn{4}{|l|}{ Magnesium } \\
\hline \multicolumn{4}{|l|}{ Manganese } \\
\hline \multicolumn{4}{|l|}{ Molybdenum } \\
\hline \multicolumn{4}{|l|}{ Nickel } \\
\hline \multicolumn{4}{|l|}{ Potassium } \\
\hline \multicolumn{4}{|l|}{ Selenium } \\
\hline \multicolumn{4}{|l|}{ Silica } \\
\hline \multicolumn{4}{|l|}{ Sodium } \\
\hline \multicolumn{4}{|l|}{ Strontium } \\
\hline \multicolumn{4}{|l|}{ Sulfate } \\
\hline \multicolumn{4}{|l|}{ Sulfide } \\
\hline \multicolumn{4}{|l|}{ Thallium } \\
\hline \multicolumn{4}{|l|}{ Tin } \\
\hline \multicolumn{4}{|l|}{ Uranium } \\
\hline \multicolumn{4}{|l|}{ Vanadium } \\
\hline Zinc & & & \\
\hline
\end{tabular}

${ }^{a}$ The screening process starts with the first column; constituents listed in the second and third columns are subtracted from the list of constituents in the first column; the remaining constituents form the list shown in the last column. 
constituents that were detected infrequently but have potential for toxicity near the detection limit.

Some constituents were screened out because they are essential nutrients present at levels within nutritional ranges even when added to expected dietary ranges (DOE, 1994; TAC, 1995). For the mill tailings area, these constituents are calcium, fluoride, potassium, and zinc (Table 3.9, column 2). For the raffinate ponds area, they are calcium, chromium, copper, fluoride, iron, potassium, and zinc (Table 3.10, column 2).

The final screening of the remaining constituents was based on their low toxic potency and/or relatively high normal dietary intake by comparison to the values measured, so that levels at which they are detected at the site would not be associated with adverse health effects even when added to expected dietary intake (DOE, 1994; TAC, 1995). For the mill tailings area, these constituents are ammonium, barium, chloride, magnesium, nitrate, silica, silver, strontium, and tin (Table 3.9, column 3). For the raffinate ponds area, they are ammonium, cobalt, magnesium, nickel, silica, strontium, sulfide, tin, and vanadium (Table 3.10, column 3). Although some contaminants have been eliminated from the lists of contaminants of potential concern, the potential for their interaction with other contaminants is discussed in Section 5.2.

Based on the screening, antimony, cadmium, lead, manganese, molybdenum, selenium, sodium, sulfate, uranium, and vanadium were chosen as final contaminants of potential concern for the human health risk assessment at the mill tailings area (Table 3.9). For the raffinate ponds area, contaminants of potential concern to human health are antimony, arsenic, cadmium, chloride, lead, manganese, molybdenum, selenium, sodium, sulfate, thallium, and uranium (Table 3.10). Also, because uranium decays to radioactive progeny, Section 6.0 evaluates the longer-lived radioactive isotopes of the uranium decay series (represented by lead-210, polonium-210, radium-226, and thorium-230). These constituents form the basis of the human health risk assessment for ground water at the Durango uranium processing site.

Because ecological impacts differ from effects on human health, the complete lists of contaminants are considered for ecological risk assessment in Section 7.0.

\subsection{CONTAMINANT FATE AND TRANSPORT}

The contaminants at the site are transported by ground water flow in the alluvium at the mill tailings area and by ground water flow within bedrock and the fault zone at the raffinate ponds area. Contaminant mobility, uptake, and toxicity depend on the species of ions that exist in the aqueous environment. The type of ion species and complexes depend on the availability of various anions and cations for the formation of complex ions and on $\mathrm{pH}$ and $\mathrm{Eh}$ conditions. Eh conditions at the processing site are notable for their wide fluctuation. Species of the contaminants of potential concern have been 
computed with the geochemical speciation code PHREEOE (Parkhurst et al., 1980) using the constituent concentrations and Eh-pH conditions observed in the most contaminated well in each area (TAC, 1995). The predominant species and their molar percentages are summarized in Tables $3.11,3.12,3.13$, and 3.14 for oxidizing and reducing conditions in both the mill tailings and raffinate ponds areas.

\section{Antimony}

Antimony is present at both areas at the site at concentrations of up to $0.17 \mathrm{mg} / \mathrm{L}$ but is generally present at much lower concentrations. Antimony is a multivalent element with $\mathrm{Sb}(\mathrm{III})$ species $\left(\mathrm{Sb}(\mathrm{OH})_{3}\right.$ aq) dominant under reducing conditions and $\mathrm{Sb}(\mathrm{V})$ species $\left(\mathrm{Sb}(\mathrm{OH})_{6}\right)$ dominant under oxidizing conditions. All known antimony compounds are very soluble; therefore, antimony concentrations at the site are not expected to be limited by solubility. Very little is known about adsorption/desorption behavior of antimony species (Rai and Zachara, 1984). Adsorption of antimony appears to have attenuated concentrations of this ion in both areas of the site, and antimony concentrations are expected to decrease further to less than $0.02 \mathrm{mg} / \mathrm{L}$.

\section{Arsenic}

At present, arsenic concentrations are generally near or below the detection limits $(0.01 \mathrm{mg} / \mathrm{L})$ in both areas of the site. This is due to sorption of the ion onto the aquifer matrix. During the period from 1990 to 1994 , the maximum values for arsenic $(0.04 \mathrm{mg} / \mathrm{L}$ ) occurred in monitor well DUR-02-602 in 1990. Since then, arsenic has not been detected. Historical data for the site demonstrate that, with transport and time, arsenic has been greatly attenuated by sorption; further attenuation is expected in the future. This will probably result in arsenic concentrations of less than $0.01 \mathrm{mg} / \mathrm{L}$ in all contaminated ground water.

\section{Cadmium}

Cadmium is present at both areas of the site, at values of up to $0.038 \mathrm{mg} / \mathrm{L}$. In the raffinate ponds area, cadmium is present at lower concentrations $\left(0.007 \mathrm{mg} / \mathrm{L}\right.$ or less). Under oxidizing conditions, cadmium ion $\left(\mathrm{Cd}^{2+}\right)$ is the dominant species in solution in the ground water at the Durango site, followed by cadmium sulfate $\left(\mathrm{CdSO}_{4}\right.$ aq $)$ and cadmium chloride $\left(\mathrm{CdCl}^{+}\right)\left(\mathrm{Table}^{3.11)}\right.$. Under reducing conditions, various cadmium hydrogen sulfide species (for example, $\mathrm{Cd}(\mathrm{HS})_{2} \mathrm{aq}$ ) are dominant (Table 3.12). It has been suggested that, in many locations, equilibrium with the mineral otavite $\left(\mathrm{CdCO}_{3}\right)$ limits solution concentrations of Cd species (Rai and Zachara, 1984). Modeling with PHREEOE (Parkhurst et al., 1980) indicates that, under oxidizing conditions, cadmium species in ground water at the Durango site are in equilibrium with otavite. However, under reducing conditions, the cadmium sulfide mineral greenockite (CdS) is the solubility-controlling solid. Thus, under both reducing and oxidizing regimes, the bulk of cadmium in the ground water has been precipitated in the 
Table 3.11 Predominant stable species of contaminants of potential concern in the ground water system under oxidizing conditions at the mill tailings area, Durango, Colorado, site ${ }^{a}$

\begin{tabular}{|c|c|c|c|c|}
\hline Contaminant & Valence & Common name & $\begin{array}{l}\text { Identity of species } \\
\text { in ground water }\end{array}$ & $\begin{array}{c}\text { Approximate } \\
\text { molar percentage }\end{array}$ \\
\hline Antimony ${ }^{b}$ & +5 & Antimony hydroxide & $\mathrm{Sb}(\mathrm{OH})_{6}^{-}$ & Dominant \\
\hline \multirow[t]{4}{*}{ Cadmium } & +2 & Cadmium ion & $\mathrm{Cd}^{2+}$ & 32 \\
\hline & +2 & Cadmium chloride & $\mathrm{CdCl}^{+}$ & 21 \\
\hline & +2 & Cadmium sulfate & $\mathrm{CdSO}_{4} \mathrm{aq}$ & 23 \\
\hline & +2 & Cadmium bicarbonate & $\mathrm{CdHCO}_{3}^{+}$ & 12 \\
\hline \multirow[t]{4}{*}{ Lead } & +2 & Lead carbonate & $\mathrm{PbCO}_{3} \mathrm{aq}$ & 65 \\
\hline & +2 & Lead bicarbonate & $\mathrm{PbHCO}_{3}^{+}$ & 15 \\
\hline & +2 & Lead sulfate & $\mathrm{PbSO}_{4} \mathrm{aq}$ & 9 \\
\hline & +2 & Lead ion & $\mathrm{Pb}^{2+}$ & 6 \\
\hline \multirow[t]{2}{*}{ Manganese } & +2 & Manganese ion & $\mathrm{Mn}^{2+}$ & 67 \\
\hline & +2 & Manganese sulfate & $\mathrm{MnSO}_{4}$ aq & 27 \\
\hline Molybdenum & +6 & Molybdate & $\mathrm{MoO}_{4}{ }^{2-}$ & 100 \\
\hline \multirow[t]{2}{*}{ Selenium ${ }^{c}$} & +4 & Hydrogen selenite & $\mathrm{HSeO}_{3}^{-}$ & Dominant \\
\hline & +4 & Selenite & $\mathrm{SeO}_{3}{ }^{2-}$ & Secondary \\
\hline Sodium & +1 & Sodium ion & $\mathrm{Na}^{+}$ & 96 \\
\hline \multirow[t]{3}{*}{ Sulfur } & -2 & Sulfate & $\mathrm{SO}_{4}{ }^{2-}$ & 71 \\
\hline & -2 & Calcium sulfate & $\mathrm{CaSO}_{4} \mathrm{aq}$ & 12 \\
\hline & -2 & Magnesium sulfate & $\mathrm{MgSO}_{4} \mathrm{aq}$ & 12 \\
\hline \multirow[t]{2}{*}{ Uranium } & +6 & Uranyl dicarbonate & $\mathrm{UO}_{2}\left(\mathrm{CO}_{3}\right)_{2}^{2-}$ & 34 \\
\hline & +6 & Uranyl tricarbonate & $\mathrm{UO}_{2}\left(\mathrm{CO}_{3}\right)_{3}^{4-}$ & 65 \\
\hline \multirow[t]{2}{*}{ Vanadium } & +5 & Dihydrogen vanadate & $\mathrm{H}_{2} \mathrm{VO}_{4}^{-}$ & 20 \\
\hline & +5 & Hydrogen divanadate & $\mathrm{HV}_{2} \mathrm{O}_{7}^{3-}$ & 78 \\
\hline
\end{tabular}

astable species of contaminants of potential concern are present at Eh and pH conditions observed in downgradient monitor well DUR-01-612 during the June 1994 sampling round. This round was notable in that the measured redox potential was oxidizing (Eh $=350$ millivolts [mV]). Aqueous species were calculated using the geochemical code PHREEOE (Parkhurst et al., 1980).

b Information from Rai and Zachara (1984).

$\mathrm{C}_{\text {Information from Brookins (1988). }}$ 
Table 3.12 Predominant stable species of contaminants of potential concern in the ground water system under reducing conditions at the mill tailings area, Durango, Colorado, site ${ }^{a}$

\begin{tabular}{|c|c|c|c|c|}
\hline Contaminant & Valence & Common name & $\begin{array}{l}\text { Identity of species } \\
\text { in ground water }\end{array}$ & $\begin{array}{c}\text { Approximate } \\
\text { molar percentage }\end{array}$ \\
\hline Antimony $\mathbf{b}$ & +3 & Antimony trihydroxide & $\mathrm{Sb}(\mathrm{OH})_{3} \mathrm{aq}$ & Dominant \\
\hline \multirow[t]{3}{*}{ Cadmium } & +2 & $\begin{array}{l}\text { Cadmium dihydrogen } \\
\text { sulfide }\end{array}$ & $\mathrm{Cd}(\mathrm{HS})_{2} \mathrm{aq}$ & 61 \\
\hline & +2 & $\begin{array}{l}\text { Cadmium trihydrogen } \\
\text { sulfide }\end{array}$ & $\mathrm{Cd}\left(\mathrm{HS}_{3}{ }^{-}\right.$ & 24 \\
\hline & +2 & $\begin{array}{l}\text { Cadmium tetrahydrogen } \\
\text { sulfide }\end{array}$ & $\mathrm{Cd}(\mathrm{HS})_{4}^{2-}$ & 15 \\
\hline Lead & +2 & Lead dihydrogen sulfide & $\mathrm{Pb}(\mathrm{HS})_{2} \mathrm{aq}$ & 95 \\
\hline Manganese & +2 & Manganese ion & $\mathrm{Mn}^{2+}$ & 92 \\
\hline Molybdenum & +6 & Molybdate & $\mathrm{MoO}_{4}^{2-}$ & 100 \\
\hline \multirow[t]{2}{*}{ Selenium ${ }^{c}$} & -2 & Hydrogen selenide & $\mathrm{H}_{2} \mathrm{Se}_{\mathrm{aq}}$ & Secondary \\
\hline & -2 & Biselenide ion & $\mathrm{HSe}^{-}$ & Dominant \\
\hline Sodium & +1 & Sodium ion & $\mathrm{Na}^{+}$ & 100 \\
\hline \multirow[t]{2}{*}{ Sulfur } & -2 & Hydrogen sulfide & $\mathrm{H}_{2} \mathrm{~S}$ aq & 92 \\
\hline & -2 & Bisulfide ion & $\mathrm{HS}^{-}$ & 8 \\
\hline Uranium & +4 & Uranium pentahydroxide & $\mathrm{U}(\mathrm{OH})_{5}^{-}$ & 96 \\
\hline \multirow[t]{2}{*}{ Vanadium } & +3 & Vanadium dihydroxide & $\mathrm{V}(\mathrm{OH})_{2}+$ & 17 \\
\hline & +3 & Vanadium trihydroxide & $\mathrm{V}(\mathrm{OH})_{3} \mathrm{aq}$ & 83 \\
\hline
\end{tabular}

aStable species of contaminants of potential concern are present at Eh and $\mathrm{pH}$ conditions observed in downgradient monitor well DUR-01-612 during the September 1993 sampling round. This round was notable in that the measured redox potential was reducing $($ Eh $=-195 \mathrm{mV})$. Aqueous species were calculated using the geochemical code PHREEOE (Parkhurst et al., 1980).

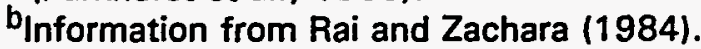

CInformation from Brookins (1988). 
Table 3.13 Predominant stable species of contaminants of potential concern in the ground water system under oxidizing conditions at the raffinate ponds area, Durango, Colorado, site ${ }^{a}$

\begin{tabular}{|c|c|c|c|c|}
\hline Contaminant & Valance & Common name & $\begin{array}{l}\text { Identity of species } \\
\text { in ground water }\end{array}$ & $\begin{array}{c}\text { Approximate } \\
\text { molar percentage }\end{array}$ \\
\hline Antimony ${ }^{b}$ & +5 & Antimony hydroxide & $\mathrm{Sb}\left(\mathrm{OH}_{6}{ }^{-}\right.$ & Dominant \\
\hline \multirow[t]{2}{*}{ Arsenic } & +5 & Hydrogen arsenate & $\mathrm{HAsO}_{4}{ }^{2-}$ & 76 \\
\hline & +5 & Dihydrogen arsenate & $\mathrm{H}_{2} \mathrm{AsO}_{4}^{-}$ & 24 \\
\hline \multirow[t]{4}{*}{ Cadmium } & +2 & Cadmium ion & $\mathrm{Cd}^{2+}$ & 25 \\
\hline & +2 & Cadmium chloride & $\mathrm{CdCl}^{+}$ & 26 \\
\hline & +2 & Cadmium sulfate & $\mathrm{CdSO}_{4} \mathrm{aq}$ & 24 \\
\hline & +2 & Cadmium disulfate & $\mathrm{Cd}\left(\mathrm{SO}_{4}\right)_{2}^{2-}$ & 12 \\
\hline Chloride & -1 & Chloride ion & $\mathrm{Cl}^{-}$ & 100 \\
\hline \multirow[t]{4}{*}{ Lead } & +2 & Lead carbonate & $\mathrm{PbCO}_{3}$ aq & 65 \\
\hline & +2 & Lead bicarbonate & $\mathrm{PbHCO}_{3}^{+}$ & 11 \\
\hline & +2 & Lead sulfate & $\mathrm{PbSO}_{4} \mathrm{aq}$ & 12 \\
\hline & +2 & Lead ion & $\mathrm{Pb}^{2+}$ & 6 \\
\hline \multirow[t]{2}{*}{ Manganese } & +2 & Manganese ion & $\mathrm{Mn}^{2+}$ & 60 \\
\hline & +2 & Manganese sulfate & $\mathrm{MnSO}_{4}$ aq & 34 \\
\hline Molybdenum & +6 & Molybdate & $\mathrm{MoO}_{4}{ }^{2-}$ & 100 \\
\hline \multirow[t]{2}{*}{ Selenium ${ }^{c}$} & +4 & Hydrogen selenite & $\mathrm{HSeO}_{3}^{-}$ & Dominant \\
\hline & +4 & Selenite & $\mathrm{SeO}_{3}^{2-}$ & Secondary \\
\hline Sodium & +1 & Sodium ion & $\mathrm{Na}^{+}$ & 94 \\
\hline \multirow[t]{3}{*}{ Sulfur } & -2 & Sulfate & $\mathrm{SO}_{4}{ }^{2-}$ & 70 \\
\hline & -2 & Magnesium sulfate & $\mathrm{MgSO}_{4} \mathrm{aq}$ & 14 \\
\hline & -2 & Sodium sulfate & $\mathrm{NaSO}_{4}^{-}$ & 10 \\
\hline \multirow[t]{2}{*}{ Uranium } & +6 & Uranyl dicarbonate & $\mathrm{UO}_{2}\left(\mathrm{CO}_{3}\right)_{2}$ & 18 \\
\hline & +6 & Uranyl tricarbonate & $\mathrm{UO}_{2}\left(\mathrm{CO}_{3}\right)^{4-}$ & 81 \\
\hline
\end{tabular}

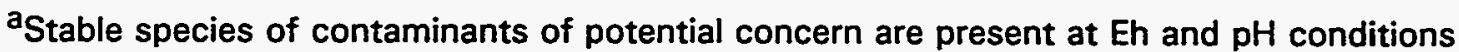
observed in downgradient monitor well DUR-02-598 during the June 1994 sampling round. This round was notable in that the measured redox potential was oxidizing (Eh $=157 \mathrm{mV}$ ). Aqueous species were calculated using the geochemical code PHREEOE (Parkhurst et al., 1980).

Information from Rai and Zachara (1984).

CInformation from Brookins (1988). 
Table 3.14 Predominant stable species of contaminants of potential concern in the ground water system under reducing conditions at the raffinate ponds area, Durango, Colorado, site

\begin{tabular}{|c|c|c|c|c|}
\hline Contaminant & Valence & Common name & $\begin{array}{l}\text { Identity of species } \\
\text { in ground water }\end{array}$ & $\begin{array}{c}\text { Approximate } \\
\text { molar percentage }\end{array}$ \\
\hline Antimony & +3 & Antimony trihydroxide & $\mathrm{Sb}(\mathrm{OH})_{3} \mathrm{aq}$ & Dominant \\
\hline Arsenic & +5 & Arsenic acid & $\mathrm{H}_{3} \mathrm{AsO}_{4} \mathrm{aq}$ & 100 \\
\hline \multirow[t]{3}{*}{ Cadmium } & +2 & $\begin{array}{l}\text { Cadmium dihydrogen } \\
\text { sulfide }\end{array}$ & $\mathrm{Cd}(\mathrm{HS})_{2} \mathrm{aq}$ & 68 \\
\hline & +2 & $\begin{array}{l}\text { Cadmium trihydrogen } \\
\text { sulfide }\end{array}$ & $\mathrm{Cd}(\mathrm{HS})_{3}^{-}$ & 20 \\
\hline & +2 & $\begin{array}{l}\text { Cadmium tetrahydrogen } \\
\text { sulfide }\end{array}$ & $\mathrm{Cd}(\mathrm{HS})_{4}^{2-}$ & 11 \\
\hline Chloride & -1 & Chloride ion & $\mathrm{Cl}^{-}$ & 100 \\
\hline Lead & +2 & Lead dihydrogen sulfide & $\mathrm{Pb}(\mathrm{HS})_{2} \mathrm{aq}$ & 96 \\
\hline \multirow[t]{2}{*}{ Manganese } & +2 & Manganese ion & $\mathrm{Mn}^{2+}$ & 59 \\
\hline & +2 & Manganese sulfate & $\mathrm{MnSO}_{4}$ aq & 35 \\
\hline Molybdenum & +6 & Molybdate & $\mathrm{MoO}_{4}{ }^{2-}$ & 100 \\
\hline \multirow[t]{2}{*}{ Selenium ${ }^{c}$} & -2 & Hydrogen selenide & $\mathrm{H}_{2} \mathrm{Se} \mathrm{aq}$ & Secondary \\
\hline & -2 & Biselenide ion & $\mathrm{HSe}^{-}$ & Dominant \\
\hline Sodium & +1 & Sodium ion & $\mathrm{Na}^{+}$ & 100 \\
\hline \multirow[t]{3}{*}{ Sulfur } & -2 & Sulfate ion & $\mathrm{SO}_{4}^{2-}$ & 67 \\
\hline & -2 & Magnesium sulfate & $\mathrm{MgSO}_{4}$ aq & 13 \\
\hline & -2 & Sodium sulfate & $\mathrm{NaSO}_{4}^{-}$ & 9 \\
\hline Uranium & +4 & Uranium pentahydroxide & $\mathrm{U}(\mathrm{OH})_{5}^{-}$ & 99 \\
\hline
\end{tabular}

aStable species of contaminants of potential concern are present at Eh and $\mathrm{pH}$ conditions observed in downgradient monitor well DUR-02-598 during the September 1993 sampling round. This round was notable in that the measured redox potential was reducing ( $E \mathrm{~h}=236 \mathrm{mV}$ ). Aqueous species were calculated using the geochemical code PHREEOE (Parkhurst et al., 1980). Information from Rai and Zachara (1984).

CInformation from Brookins (1988). 
subsurface near the source of contamination. These deposits will form a secondary source of cadmium contamination that will continue to release cadmium, in equilibrium amounts, until solids are completely dissolved. As a result, adsorption, dilution, and dispersion will, over time, be the primary mechanisms that reduce cadmium concentrations at the site.

\section{Chloride}

Chloride concentrations in the contaminated ground water are about 20 times those of background levels. Chloride is a nonreactive ion in ground water; thus, decreases in concentrations will be due to dilution and dispersion without the benefit of adsorption.

\section{Lead}

Lead occurs as a contaminant at both areas of the site at levels up to $0.07 \mathrm{mg} / \mathrm{L}$ but is generally below detection levels (less than $0.01 \mathrm{mg} / \mathrm{L}$ ). Adsorption has been effective in removing lead from ground water, and further decreases in lead concentrations are expected in the future.

\section{Manganese}

Manganese is present at both areas of the site at similar levels (up to about $8 \mathrm{mg} / \mathrm{L})$. Under reducing conditions, manganese ion $\left(\mathrm{Mn}^{2+}\right)$ accounts for 92 percent of manganese species in ground water at the site (Table 3.12). When conditions become more oxidizing, the percentage of manganese ion goes down and manganese sulfate $\left(\mathrm{MnSO}_{4} \mathrm{aq}\right.$ ) and manganese bicarbonate $\left(\mathrm{MnHCO}_{3}{ }^{+}\right.$) become more important (Table 3.11). Several samples of ground water at the site are near saturation with respect to the mineral rhodochrosite $\left(\mathrm{MnCO}_{3}\right)$ and, in the past, manganese was probably precipitated out of solution as rhodochrosite. These deposits will form a secondary source of manganese that will continue to release manganese in equilibrium amounts labout 2 to $10 \mathrm{mg} / \mathrm{L}$ ) until the solids are completely dissolved. As a result, decreases in concentrations will be due to dilution and dispersion without the benefit of adsorption.

\section{Molybdenum}

Molybdenum is present at both areas of the site. In the former raffinate ponds area, molybdenum is limited to concentrations of about $0.02 \mathrm{mg} / \mathrm{L}$ or less, and adsorption appears to be effective in removing molybdenum from ground water. In the mill tailings area, molybdenum is present at concentrations of up to about $0.2 \mathrm{mg} / \mathrm{L}$, and adsorption appears to be less effective in removing this constituent from ground water in the gravel. Thus, in the mill tailings area, adsorption of molybdenum in the contaminated ground water will be less important than dilution and dispersion as a mechanism for decreasing concentrations. 


\section{Selenium}

Selenium occurs at both areas of the site at concentrations of up to $1.11 \mathrm{mg} / \mathrm{L}$ (in unfiltered samples). Selenium appears to have been introduced to the aquifer at the site as an adsorbed ion on suspended solids. Changes in ground water composition, especially near-surface dilution, appear to be mobilizing this selenium. Under oxidizing conditions, selenium exists dominantly as hydrogen selenite and under reducing conditions, dominantly as hydrogen selenide. Sorption of these selenium anionic species is most effective under acid conditions ( $\mathrm{pH}$ less than 4). Thus, under the near-neutral $\mathrm{pH}$ conditions at the site, both anionic species are mobile in ground water. Therefore, dilution and dispersion are likely to be the primary mechanisms for reducing selenium concentrations at the site.

\section{Sodium}

Sodium occurs as a contaminant in both areas of the site, at concentrations of up to about $3900 \mathrm{mg} / \mathrm{L}$. Sodium forms very soluble bicarbonate, chloride, and sulfate salts; thus, precipitation of those salts will not occur. A likely mechanism for their removal is cation exchange for calcium within clay minerals. Geochemical modeling suggests that such exchange has been occurring in the contaminated ground water within bedrock at the raffinate ponds area ITAC, 1995). Modeling also suggests that the most contaminated ground water in the raffinate ponds area is not yet equilibrated to natural clays at the site and that sodium concentrations will continue to decrease, ultimately reaching a level of about $400 \mathrm{mg} / \mathrm{L}$ (Table 3.5) (similar to background levels). By contrast, the gravel at the mill tailings area appears to have little cation exchange capacity. Therefore, dilution and dispersion will be most effective in decreasing sodium concentrations in this area.

\section{Sulfate}

Sulfate is a contaminant at both areas of the site. It occurs at concentrations of up to about $10,000 \mathrm{mg} / \mathrm{L}$ at the former raffinate ponds area and up to $3300 \mathrm{mg} / \mathrm{L}$ at the mill tailings area. Modeling with PHREEQE (Parkhurst et al., $1980)$ predicts that sulfate $\left(\mathrm{SO}_{4}{ }^{2-}\right)$ will be the dominant sulfur species in ground water at the site under oxidizing conditions, followed by calcium sulfate $\left(\mathrm{CaSO}_{4}\right)$ and magnesium sulfate $\left(\mathrm{MgSO}_{4}\right.$ aq) (TAC, 1995). By contrast, under reducing conditions, dihydrogen sulfide $\left(\mathrm{H}_{2} \mathrm{~S} a \mathrm{a}\right.$ ) is dominant, followed by hydrogen sulfide ion (HS). Under reducing conditions, actual sulfate concentrations in the ground water change very little. This is due to slow kinetics of reduction. The sulfur species that are reduced may be precipitated as insoluble sulfides (for instance, the mineral sphalerite $(\mathrm{ZnS}$ ) is oversaturated during reducing conditions), or dihydrogen sulfide gas $\left(\mathrm{H}_{2} \mathrm{~S}\right)$ may release and thus remove sulfur species from the system. However, any sulfate removed from the ground water by these mechanisms will likely be small. Modeling with PHREEQE (Parkhurst et al., 1980) indicates that under oxidizing conditions, gypsum is at equilibrium and should have a tendency to precipitate. These 
precipitates would then become a secondary source of sulfate, supplying this ion to the ground water in equilibrium concentrations until solids were completely dissolved and the entire system had moved downgradient.

In the raffinate ponds area, modeling indicates that acid neutralization and cation exchange coupled with gypsum precipitation have been effective in decreasing sulfate concentrations (Table 3.5). Furthermore, the capacity exists for future sulfate decreases to values of about $2500 \mathrm{mg} / \mathrm{L}$. However, the gypsum precipitate will become a secondary source for sulfate and will supply sulfate to ground water in equilibrium concentrations until the solid is completely dissolved. Thus, the primary mechanisms for decreasing sulfate concentrations at the raffinate ponds area will be dilution and dispersion.

\section{Thallium}

Thallium has been detected in ground water at the raffinate ponds area at values of up to $0.06 \mathrm{mg} / \mathrm{L}$; however, in general, thallium is below detection limits (less than $0.01 \mathrm{mg} / \mathrm{L})$. In the future, adsorption will act to keep thallium at low levels (less than $0.01 \mathrm{mg} / \mathrm{L}$ ).

\section{Uranium}

Uranium occurs as a contaminant at both areas of the site at levels up to about $4.0 \mathrm{mg} / \mathrm{L}$. Under oxidizing conditions, uranium occurs in ground water at the site dominantly as a uranyl carbonate complex (for example, $\mathrm{UO}_{2}\left(\mathrm{CO}_{3}\right)_{3}^{4-}$ ). This complex is mobile in neutral-to-alkaline ground water; thus, under oxidizing conditions, dilution will be the primary control on uranium concentrations. Under reducing conditions, modeling with PHREEOE (Parkhurst et al., 1980) indicates that several uranium oxide phases, including the mineral uraninite $\left(\mathrm{UO}_{2}\right)$, are oversaturated at the site (TAC, 1995). Other phases include amorphous uranium dioxide $\left(\mathrm{UO}_{2}\right)$, colloidal uranium oxide $\left(\mathrm{U}_{4} \mathrm{O}_{9}\right)$, and colloidal uranium silicate $\left(\mathrm{USiO}_{4}\right)$. As a result, under reducing conditions, uranium would tend to be removed from solution. This would have the effect of retarding the movement of uranium downgradient.

\section{Vanadium}

Vanadium occurs at both areas of the site, but relatively high concentrations (up to about $0.5 \mathrm{mg} / \mathrm{L}$ ) are restricted to the mill tailings area. At the raffinate ponds area, adsorption appears to be effective in removing vanadium from ground water within the bedrock and fault. Such sorption does not appear to be as effective in the alluvial gravel at the mill tailings area. Under oxidizing conditions at the site, vanadium exists in ground water in its maximum oxidation state $(+5)$ as a vanadate ion (primarily $\mathrm{HV}_{2} \mathrm{O}_{7}^{3-}$ ). The mineral tyuyamunite $\left(\mathrm{Ca}\left(\mathrm{UO}_{2}\right)\left(\mathrm{VO}_{4}\right)_{2} \cdot \mathrm{nH}_{2} \mathrm{O}\right)$ is oversaturated during these conditions. As conditions become reducing, vanadium hydroxide complexes $(+3$ oxidation state) become more stable $\left(\mathrm{V}(\mathrm{OH})_{2}{ }^{+}\right.$and $\mathrm{V}(\mathrm{OH})_{3}$ aq) (Table 3.12) and vanadium oxides $\left(\mathrm{V}_{2} \mathrm{O}_{3}\right.$ and $\left.\mathrm{V}_{3} \mathrm{O}_{5}\right)$ will tend to precipitate out. Generally, the 
solubility of the controlling vanadium solids is apparently greater under reducing rather than oxidizing conditions (Rai and Zachara, 1984). Little is known about the adsorptive behavior of vanadium species, but vanadates are known to be adsorbed by iron oxides (Rai and Zachara, 1984). For these reasons, vanadium should be more mobile under reducing conditions. Overall, vanadium appears to be mobile at the mill tailings area of the site; thus, dilution and dispersion will be the primary mechanisms for reducing concentrations in ground water in this area.

\section{$3.5 \quad$ SURFACE WATER MONITORING}

The Durango uranium ore processing site is bounded by Lightner Creek to the north, the Animas River to the east, and South Creek to the south. Hydraulic gradients (Figures 2.3 and 2.7) indicate that the Animas River could potentially receive ground water discharge from the tailings and raffinate ponds areas of the site. Therefore, surface water and sediment were sampled during November 1993 to assess impacts of ground water discharge on those media. This sampling period was chosen to coincide with the seasonal low flow in the river and creeks, because the potential impact of contaminant discharge would be greatest during this period. The results of this sampling and analysis are presented in Tables 3.15 and 3.16 .

Both filtered and unfiltered samples of surface water were also collected monthly by the BOR at two locations along the Animas River. One location was upstream of the site and the second was downstream, at the raffinate ponds area. This sampling included water analyses during both low and high river flow during the period from January 1993 through July 1993. Analytical results are summarized in Table 3.17.

In Lightner Creek, background surface water and sediments were sampled one time at location DUR-01-650, approximately $500 \mathrm{ft}(150 \mathrm{~m})$ upstream of the site (Figure 3.1). Downstream samples were also collected once at location DUR-01-651, near the confluence of Lightner Creek and the Animas River. Comparison of water quality data at these two locations for this sampling event does not indicate a difference in water quality upstream and downstream of the site (Table 3.15). Lightner Creek sediments also appear comparable upstream and downstream of the site for this one-time sampling event (Table 3.16). Thus, there are no anomalous constituents in Lightner Creek sediments attributable to uranium processing activities, based on one sampling round.

In the Animas River, background surface water and sediment were sampled at location DUR-01-652, about $300 \mathrm{ft}(90 \mathrm{~m})$ upstream of the site, and immediately upstream of the confluence of the Lightner Creek and the Animas River. On-site and downstream locations were sampled to determine potential impacts of the site on surface water sediments and sediments in the Animas River. Location DUR-01-690 is immediately downstream of the confluence of the Animas River and Lightner Creek. Location DUR-01-691 is located downstream of the mill tailings area. Location DUR-02-657 is downstream of 


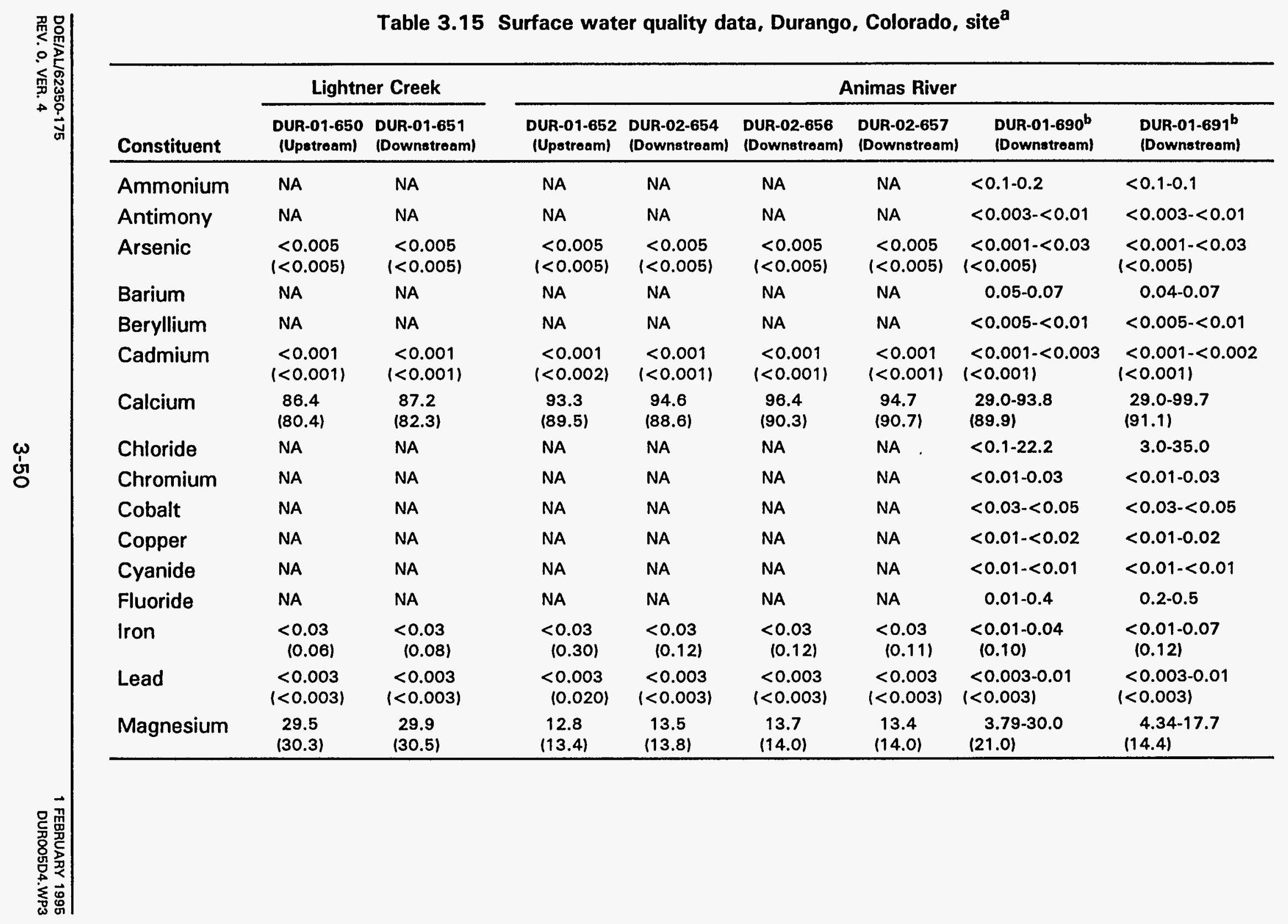




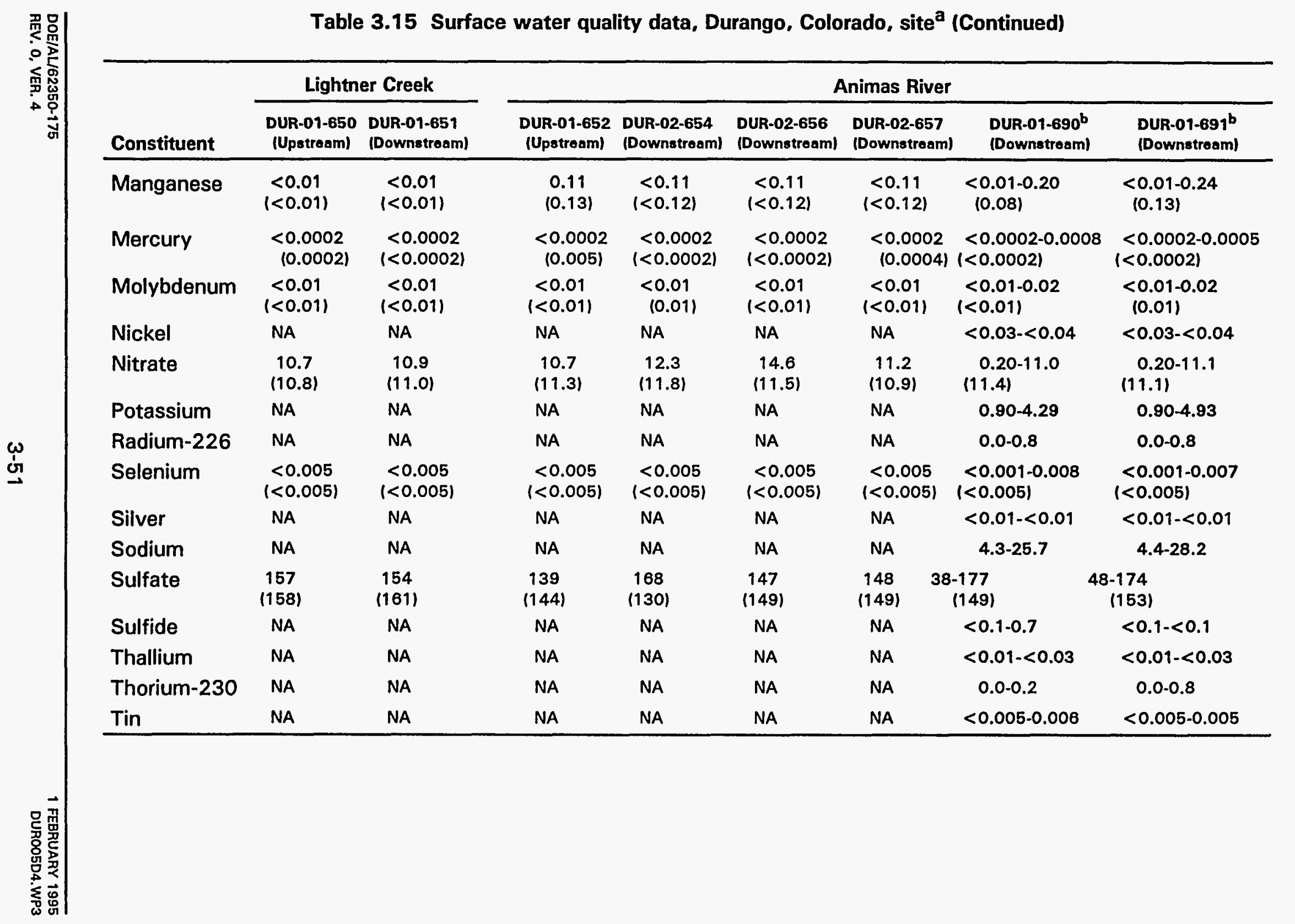


Table 3.15 Surface water quality data, Durango, Colorado, site ${ }^{\mathrm{a}}$ (Concluded)

\begin{tabular}{|c|c|c|c|c|c|c|c|c|}
\hline \multirow[b]{2}{*}{ Constituent } & \multicolumn{2}{|c|}{ Lightner Creek } & \multicolumn{6}{|c|}{ Animas River } \\
\hline & $\begin{array}{c}\text { DUR-01-650 } \\
\text { (Upstream) }\end{array}$ & $\begin{array}{l}\text { DUR-01-651 } \\
\text { (Downetream) }\end{array}$ & $\begin{array}{c}\text { DUR-01-652 } \\
\text { (Upstream) }\end{array}$ & $\begin{array}{l}\text { DUR-02-654 } \\
\text { (Downstroam) }\end{array}$ & $\begin{array}{l}\text { DUR-02-656 } \\
\text { (Downstream) }\end{array}$ & $\begin{array}{l}\text { DUR-02-657 } \\
\text { (Downstream) } \\
\end{array}$ & $\begin{array}{l}\text { DUR-01-690' } \\
\text { (Downstroam) }\end{array}$ & $\begin{array}{l}\text { DUR-01-691'b } \\
\text { (Downstroam) }\end{array}$ \\
\hline Uranium & $\begin{array}{l}<0.001 \\
(<0.001)\end{array}$ & $\begin{array}{l}<0.001 \\
|<0.001|\end{array}$ & $\begin{array}{l}<0.001 \\
|<0.001|\end{array}$ & $\begin{array}{c}<0.001 \\
|<0.001|\end{array}$ & $\begin{array}{c}<0.001 \\
\mid<0.001)\end{array}$ & $\begin{array}{c}0.001 \\
(<0.001)\end{array}$ & $\begin{array}{l}0.0006-0.0055 \\
(<0.001)\end{array}$ & $\begin{array}{l}0.0006-0.0029 \\
1<0.001)\end{array}$ \\
\hline Vanadium & NA & NA & NA & NA & NA & NA & $<0.01-0.01$ & $<0.01-0.01$ \\
\hline Zinc & $\begin{array}{c}0.009 \\
(0.031)\end{array}$ & $\begin{array}{c}0.010 \\
(0.026)\end{array}$ & $\begin{array}{c}0.051 \\
(0.116) \\
\end{array}$ & $\begin{array}{c}0.012 \\
(0.088) \\
\end{array}$ & $\begin{array}{c}0.019 \\
(0.088) \\
\end{array}$ & $\begin{array}{c}0.008 \\
(0.093) \\
\end{array}$ & $\begin{array}{l}<0.005-0.107 \\
(0.061)\end{array}$ & $\begin{array}{l}0.012-0.131 \\
(0.083) \\
\end{array}$ \\
\hline
\end{tabular}

${ }^{a}$ Concentrations are reported in milligrams per liter. Unfiltered samples are reported in parentheses under filtered data when available. For locations DUR-01-650, -651, and -652 and DUR-02-654, -656, and -657, reported values are from the November 1993 sampling round (the only data available).

b Sampling at locations DUR-01-690 and -691 was performed during several rounds between 1987 and 1993 . The range of concentrations (minimum and maximum) is reported based on all available data. If a high detection limit reported for a non-detect sample exceeded the maximum detectable concentration for a constituent, the maximum detect is reported.

DUR-01 - mill tailings area.

DUR-02 - raffinate ponds area.

NA - not analyzed. 


\begin{tabular}{|c|c|c|c|c|c|c|c|c|c|}
\hline \multirow{3}{*}{ 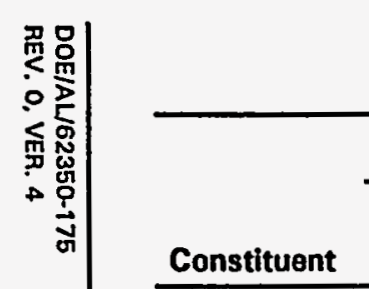 } & \multicolumn{9}{|c|}{ Table 3.16 Sediment quality data, Durango, Colorado, site ${ }^{a}$} \\
\hline & \multicolumn{2}{|c|}{ Lightner Creek } & \multicolumn{7}{|c|}{ Animas River } \\
\hline & $\begin{array}{c}650 \\
\text { (Upstroam) }\end{array}$ & $\begin{array}{c}651 \\
\text { (Downstream) }\end{array}$ & $\begin{array}{c}652 \\
\text { (Upstroam) }\end{array}$ & $\begin{array}{c}654 \\
\text { (Downstroam) }\end{array}$ & $\begin{array}{c}656 \\
\text { (Downstream) }\end{array}$ & $\begin{array}{c}657 \\
\text { (Downstroam) }\end{array}$ & $\begin{array}{c}690 \\
\text { (Downstroam) }\end{array}$ & $\begin{array}{c}691 \\
\text { (Downstroam) }\end{array}$ & $\begin{array}{l}\text { DUR-02-655 } \\
\text { (Downstream) }\end{array}$ \\
\hline Arsenic & 9.5 & 8.8 & 12.0 & 31.2 & 12.1 & 11.9 & 9.7 & 14.1 & 8.1 \\
\hline Cadmium & 1.4 & 0.7 & 9.0 & 3.2 & 3.6 & 4.0 & 1.2 & 1.8 & 1.1 \\
\hline Iron & 22,100 & 19,800 & 16,300 & 32,800 & 25,300 & 16,500 & 17,000 & 17,300 & 13,500 \\
\hline Lead & 23.8 & 14.7 & 152 & 106 & 159 & 75.6 & 26.3 & 39.6 & 25.8 \\
\hline Manganese & 215 & 229 & 1,520 & 736 & 1200 & 825 & 231 & 569 & 486 \\
\hline Mercury & $<0.10$ & $<0.10$ & $<0.10$ & $<0.10$ & $<0.10$ & $<0.10$ & $<0.10$ & $<0.10$ & $<0.10$ \\
\hline Molybdenum & 3 & 2 & 7 & $<1.0$ & 4 & $<1.0$ & 3 & 2 & 8 \\
\hline Nitrate & $<0.10$ & $<0.10$ & $<0.10$ & 2.3 & $<1.0$ & $<1.0$ & $<0.10$ & $<1.0$ & 1.5 \\
\hline Selenium & 1.6 & 1.6 & 1.2 & 0.6 & 1.0 & 0.7 & 1.6 & 1.9 & $<0.5$ \\
\hline Sulfate & 61.3 & 69.6 & 204 & 196 & 14.2 & 53.7 & 69.5 & 57.6 & 6,920 \\
\hline Uranium & 1.5 & 1.4 & 3.2 & 1.8 & 2.3 & 1.7 & 1.5 & 1.6 & 2.4 \\
\hline Zinc & 134 & 82.5 & 443 & 210 & 702 & 254 & 99.9 & 241 & 54.7 \\
\hline
\end{tabular}

${ }^{a}$ Concentrations are reported in milligrams per kilogram. Values reported are from a single sampling round in November 1993.

bSample was collected from the Animas River shore above the water line. Sample was associated with evaporites.

DUR-02 - raffinate ponds area. 


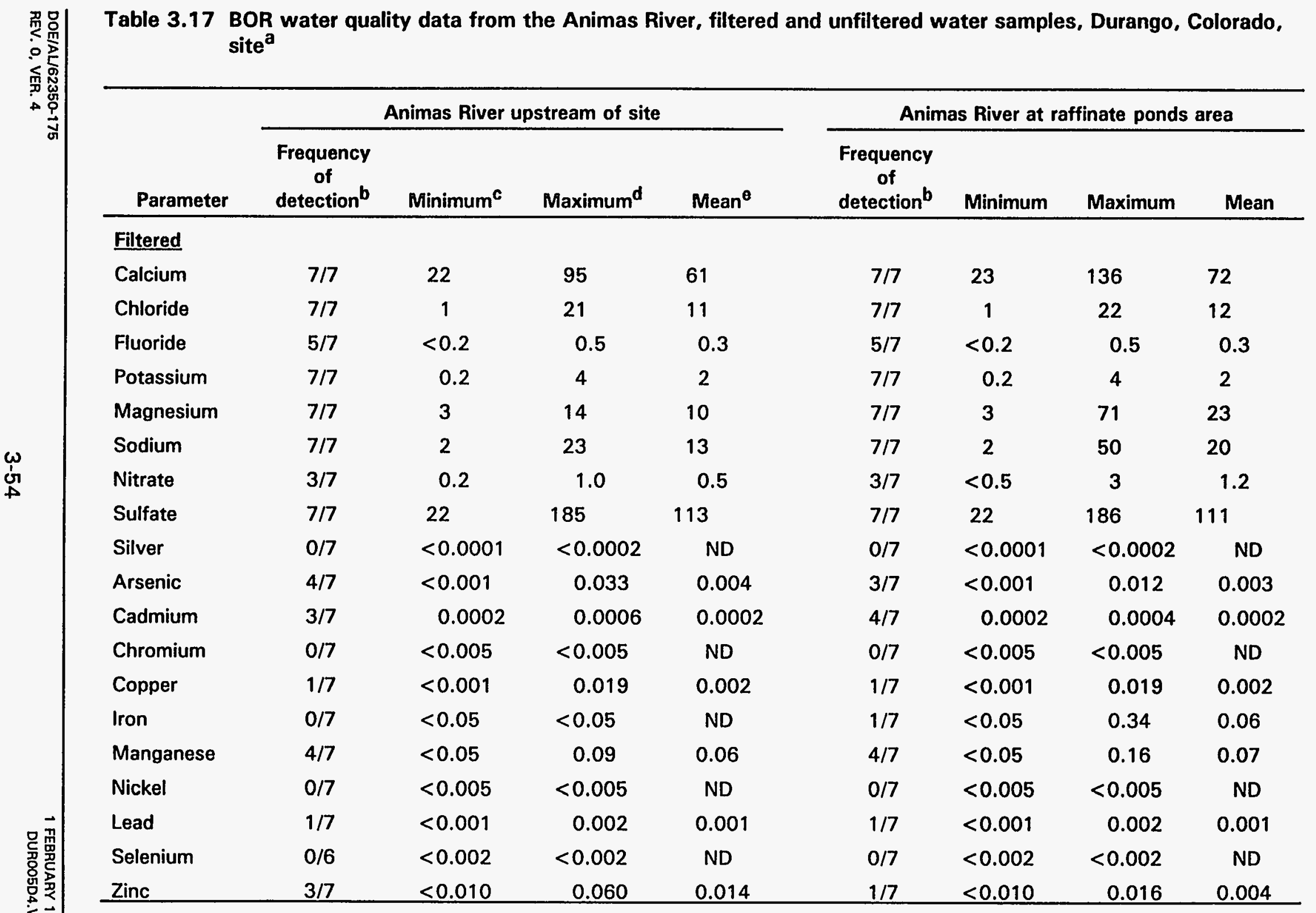


Table 3.17 BOR water quality data from the Animas River, filtered and unfiltered water samples, Durango, Colorado, site $^{\mathrm{a}}$ (Concluded)

\begin{tabular}{|c|c|c|c|c|c|c|c|c|}
\hline \multirow[b]{2}{*}{ Parameter } & \multicolumn{4}{|c|}{ Animas River upstream of site } & \multicolumn{4}{|c|}{ Animas River at raffinate ponds area } \\
\hline & $\begin{array}{c}\text { Frequency } \\
\text { of } \\
\text { detection }^{b}\end{array}$ & Minimum ${ }^{c}$ & Maximum $^{\mathrm{d}}$ & Mean $^{\ominus}$ & $\begin{array}{c}\text { Frequency } \\
\text { of } \\
\text { detection }^{b}\end{array}$ & Minimum & Maximum & Mean \\
\hline \multicolumn{9}{|l|}{ Unfiltered } \\
\hline Silver & $5 / 7$ & $<0.0001$ & 0.0005 & 0.0002 & $6 / 7$ & $<0.0001$ & 0.0005 & 0.0002 \\
\hline Arsenic & $7 / 7$ & 0.011 & 0.087 & 0.031 & $7 / 7$ & 0.009 & 0.089 & 0.032 \\
\hline Cadmium & $5 / 7$ & $<0.0003$ & 0.0009 & 0.0006 & $6 / 7$ & $<0.0003$ & 0.0016 & 0.0006 \\
\hline Chromium & $5 / 7$ & $<0.005$ & 0.021 & 0.011 & $6 / 7$ & $<0.005$ & 0.019 & 0.013 \\
\hline Copper & $5 / 7$ & $<0.005$ & 0.031 & 0.013 & $5 / 7$ & $<0.005$ & 0.036 & 0.014 \\
\hline Iron & $7 / 7$ & 0.20 & 1.01 & 0.41 & $7 / 7$ & 0.15 & 1.90 & 0.67 \\
\hline Manganese & $7 / 7$ & 0.08 & 0.33 & 0.19 & $7 / 7$ & 0.08 & 0.37 & 0.23 \\
\hline Nickel & $7 / 7$ & 0.006 & 0.036 & 0.015 & $6 / 7$ & $<0.005$ & 0.034 & 0.015 \\
\hline Lead & $6 / 7$ & 0.003 & 0.080 & 0.018 & $6 / 7$ & $<0.005$ & 0.026 & 0.011 \\
\hline Selenium & $4 / 7$ & $<0.002$ & 0.034 & 0.007 & $5 / 7$ & $<0.002$ & 0.028 & 0.007 \\
\hline Zinc & $7 / 7$ & 0.06 & 0.24 & 0.11 & $7 / 7$ & 0.06 & 0.28 & 0.13 \\
\hline Uranium & $0 / 4$ & $<0.005$ & $<0.005$ & ND & $0 / 4$ & $<0.005$ & $<0.005$ & ND \\
\hline
\end{tabular}

${ }^{a}$ All concentrations reported in milligrams per liter; samples collected monthly from January 1993 through July 1993.

${ }^{b}$ Frequency of detection $=$ number of analyses above the detection limit/the total number of analyses.

cMinimum detected concentration or detection limit, whichever is lower.

Maximum detected concentration.

eArithmetic average; for analyses below detection, one-half the detection limit was used as a proxy concentration in the calculations.

BOR - Bureau of Reclamation.

ND - not detected. 
the mill tailings area and sewage treatment plant outfall, but upstream of the raffinate ponds area. DUR-02-656 is midway along the stretch of river potentially affected by the raffinate ponds area. DUR-02-654 is located downstream of both the mill tailings and raffinate ponds areas. Water in the Animas River at Durango is a calcium-bicarbonate or calcium-bicarbonate-sulfate type, generally ranging from hard to very hard, with calculated hardness values ranging from approximately 70 to $670 \mathrm{mg} / \mathrm{L}$ expressed as calcium carbonate. A comparison of downstream and upstream water quality data indicates similar surface water quality (Table 3.15 ).

Additional data collected and analyzed by the BOR are consistent with the DOE data. These data indicate that concentrations of contaminants of potential concern are the same or similar upstream and downstream of the site for both filtered and unfiltered surface water samples from the Animas River (Table 3.17). Thus, ground water that may be discharging from the site to the Animas River appears to have a negligible impact on surface water quality in the Animas River.

Based on the samples collected in November 1993, Animas River sediments are similar at the downstream locations compared to the upstream location (Table 3.16). Sample DUR-02-655 was collected above the river shoreline, in sediments associated with surface evaporites (TAC, 1994b). It contained high concentrations of sulfate. The source of the sulfate could be either evaporated river water or ground water. The evaporite is not associated with elevated concentrations of processing-related metals, including uranium, molybdenum, and manganese.

Overall, most analyzed concentrations of elements in sediments from the Animas River are similar (within a factor of 2) to the average abundance of elements in rocks and sediments of the earth (Krauskopf, 1979). However, levels of cadmium, lead, and zinc are greater than average by a factor of 10 . All three are elevated in the upstream sediment sample and are commonly associated with naturally occurring lead-zinc deposits. Therefore, they could be derived from the erosion of natural lead and zinc deposits within the Animas River drainage basin and/or from erosion of ores, mine spoil, and other products of mining in the region.

\subsection{GROUND WATER DISCHARGE MODELING}

The potential effect of contaminated ground water discharge on water quality in the Animas River has been modeled to estimate potential water quality changes in the Animas River due to ground water discharge from the site. This model was conducted for three reasons. First, only limited measurements of surface water quality data are available. Second, the Animas River has several possible sources of contaminants of potential concern, and determining the potential contribution of UMTRA Project site-specific discharges is needed. Third, some contaminants of potential concern may be toxic to aquatic organisms at levels below detection limits. The contributions of site-specific discharge to Animas 
River water quality are estimated for low-flow conditions when the contribution is the greatest. Effects have been modeled for both the mill tailings and raffinate ponds areas under worst-case conditions (TAC, 1995).

In the mill tailings area, ground water in the alluvial gravels discharges to the Animas River at the downgradient (southeastern) end of the area (Figure 2.3). Hydraulic conductivity in the gravels averages $20 \mathrm{ft} /$ day $\left(7 \times 10^{-3} \mathrm{~cm} / \mathrm{s}\right)$ (Section 2.4.1), and the hydraulic gradient in the gravels is approximately 0.02 (derived from contour lines in Figure 2.3). The product of these values is the specific ground water discharge per square foot or square meter of crosssectional area perpendicular to the direction of flow $10.4 \mathrm{ft}^{3} /$ square foot $\left[\mathrm{ft}^{2}\right.$ ] day) $\left(0.12 \mathrm{~m}^{3} / \mathrm{square}\right.$ meter $\left[\mathrm{m}^{2}\right]$-day). The depth of contaminated ground water in the gravel aquifer is approximately $8 \mathrm{ft}(2.4 \mathrm{~m})$, which is the distance between the water table and the base of the alluvium. The width of the contaminated aquifer as it discharges into the Animas River is approximately $450 \mathrm{ft}(140 \mathrm{~m})$ (Figure 2.3). The product of these two values, perpendicular to flow, is the cross-sectional area of gravel aquifer containing contaminated ground water $\left(3600 \mathrm{ft}^{2}\left[330 \mathrm{~m}^{2}\right]\right)$. Multiplying this area by the specific discharge gives a total potential volume of discharge from the aquifer to the Animas River of $1440 \mathrm{ft}^{3}\left(40 \mathrm{~m}^{3}\right)$ per day.

The record 7-day low flow in the Animas River was $100 \mathrm{ft}^{3} / \mathrm{s} 13 \mathrm{~m}^{3} / \mathrm{s}$ ) (Section $2.5)$, or $8,640,000 \mathrm{ft}^{3}\left(250,000 \mathrm{~m}^{3}\right)$ per day. This is several thousand times the ground water discharge to the river from the mill tailings area. Thus, contaminants discharging to the river are greatly diluted. The increment of contamination added to the river by ground water discharge has been calculated by taking the product of the maximum observed concentration of a constituent in the contaminated ground water, multiplying this concentration by the volume of ground water discharge, and dividing the result by the 7-day low flow river volume. For example, for uranium, the maximum concentration observed in the mill tailings area was $4.0 \mathrm{mg} / \mathrm{L}$. After dilution, this would increase the uranium concentration in the Animas River by $0.0007 \mathrm{mg} / \mathrm{L}$ above background concentrations at low flow in the river. During average or high river flow, this uranium level would be less.

The results of the calculations for uranium and other constituents are presented in Table 3.18, as well as concentrations measured upstream of the site. The results indicate that, under average conditions of ground water flow, there would be no detectable effect on surface water quality, with the possible exception of uranium, which would be increased by approximately $0.0007 \mathrm{mg} / \mathrm{L}$.

Using the highest observed value for hydraulic conductivity in the gravel aquifers $(300 \mathrm{ft}[90 \mathrm{~m}]$ per day) (Section 2.4.1) would result in a 15-fold increase in the incremental values of constituents calculated using the average hydraulic conductivity, including an increase in uranium concentration to approximately $0.01 \mathrm{mg} / \mathrm{L}$. This latter change, as well as changes in zinc, manganese, and cadmium levels, could be detected, though changes in other 


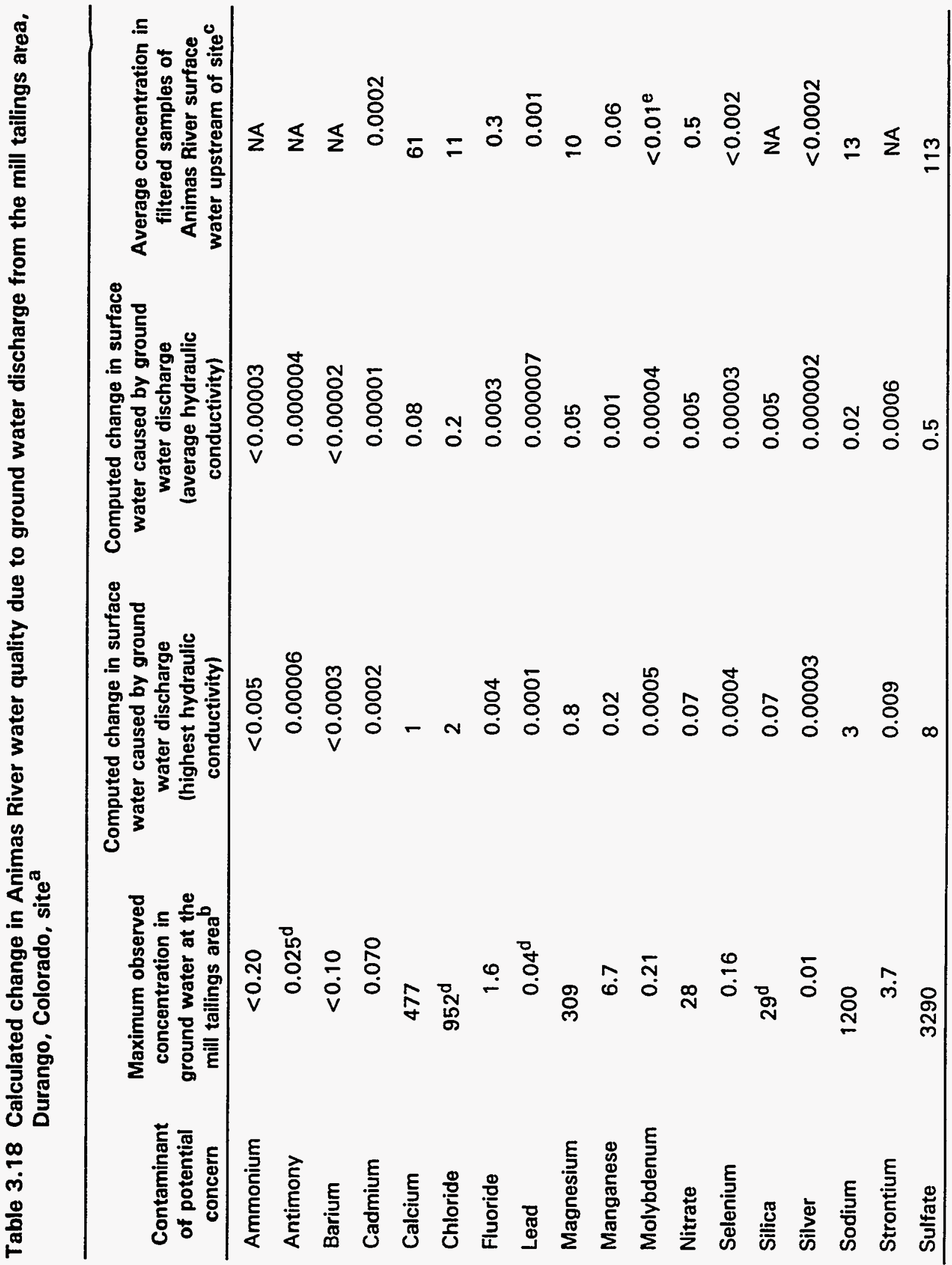




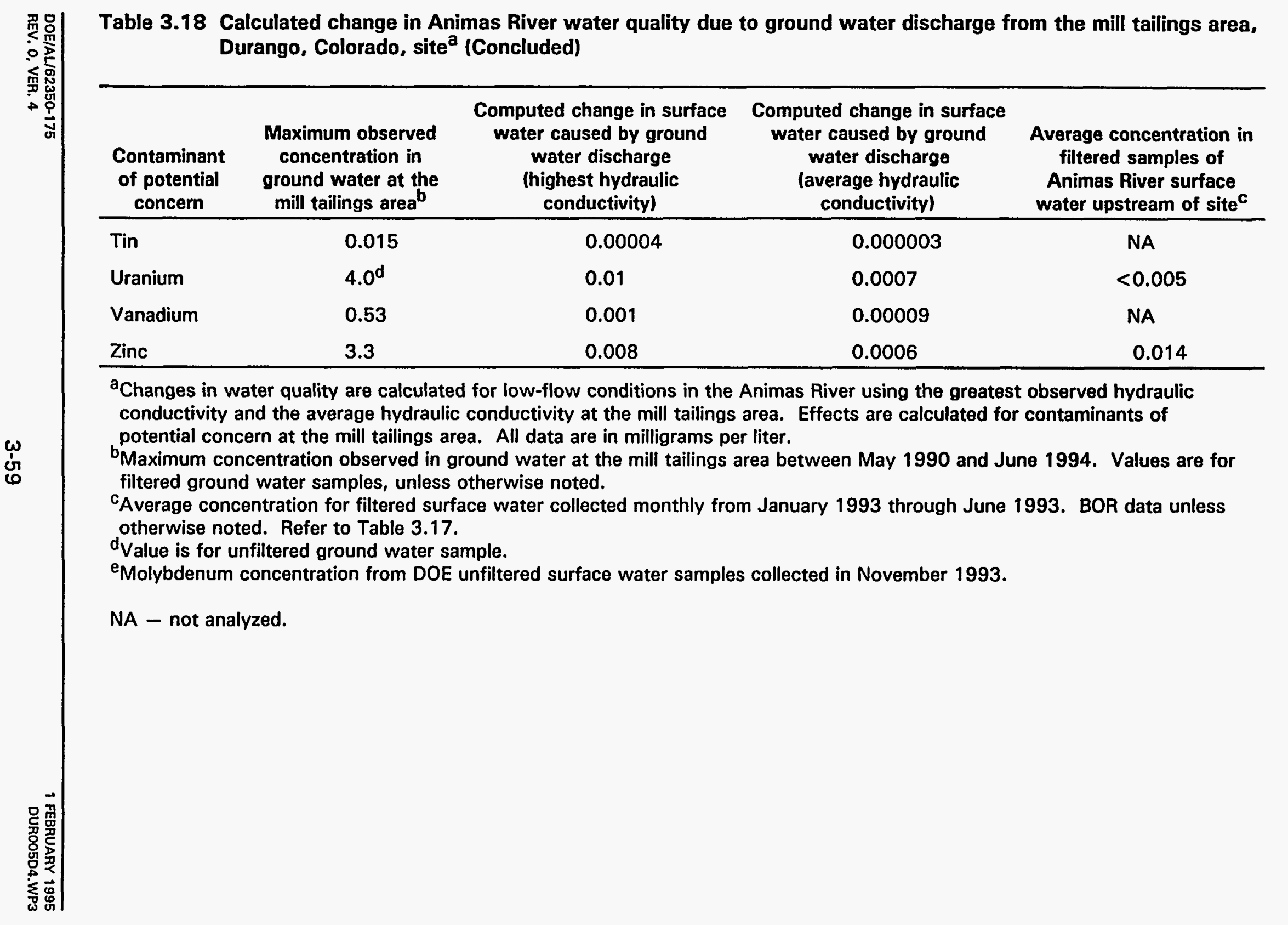


constituents could not. However, this represents worse-than-expected conditions, including a higher-than-average rate of ground water flow and lower-than-average rate of river flow.

A similar set of calculations was done for the raffinate ponds area (TAC, 1995). There are two potential sources of ground water discharge to the Animas River in this area: general discharge from the bedrock to the river and more focused discharge from the fault where it intercepts the river bottom. Discharge from the fault to the river was computed using a component of the hydraulic gradient measured parallel to the fault (from water levels measured in monitor wells DUR-02-592 and -598) (Figure 3.3). This gradient is 0.023 . The average hydraulic conductivity within the fault zone is $0.8 \mathrm{ft} /$ day $\left(3 \times 10^{-4} \mathrm{~cm} / \mathrm{s}\right)$ (Section 2.4.2). The width of the fault and associated fracture zone was estimated to be $10 \mathrm{ft}(3 \mathrm{~m})$ from boring logs obtained from the BOR (1990). Finally, the depth of contamination was estimated to be about $200 \mathrm{ft}(60 \mathrm{~m})$ from the top of the water table. This depth was estimated by taking the computed depth of contamination (approximately $100 \mathrm{ft}[30 \mathrm{~m}]$, as discussed in Section 3.2) and doubling that depth to account for uncertainties in the volume of raffinate disposed of at the site. Using these data, the potential volume of contaminated ground water discharge to the river from the fault is computed to be about $37 \mathrm{ft}^{3}\left(1 \mathrm{~m}^{3}\right)$ per day. This is an upper-bound estimate because it assumes that all ground water to a depth of $200 \mathrm{ft}(60 \mathrm{~m})$ discharges to the Animas River.

For the bedrock, the average hydraulic conductivity is $0.2 \mathrm{ft} / \mathrm{day}\left(8 \times 10^{-5} \mathrm{~cm} / \mathrm{s}\right)$ and the measured hydraulic gradient is 0.03 (Section 2.4.2). The crosssectional area of the contaminated ground water perpendicular to flow is approximately $430,000 \mathrm{ft}^{2}\left(40,000 \mathrm{~m}^{2}\right)$, which is calculated from a flow width of $2150 \mathrm{ft}(660 \mathrm{~m})$ parallel to the river and a flow depth $200 \mathrm{ft}(61 \mathrm{~m})$. This latter value is based on doubling the computed depth of contamination, as discussed above. Using these values, the potential volume of ground water discharge from bedrock to the river is approximately $2600 \mathrm{ft}^{3}\left(70 \mathrm{~m}^{3}\right)$ per day, which overshadows the contribution from the fault. This is an upper-bound estimate because it assumes that all contaminated ground water to a depth of $200 \mathrm{ft}(60 \mathrm{~m})$ discharges to the Animas River at an equal rate. In fact, most discharge would be from the shallower portion of the aquifer.

Thus, the total discharge from the fault and bedrock is about $2600 \mathrm{ft}^{3}\left(70 \mathrm{~m}^{3}\right)$ per day, a very small quantity compared to the daily flow of the Animas River, even under low-flow conditions. Therefore, contaminants are greatly diluted as they enter the river. The incremental effect of the ground water discharge from the raffinate ponds area to the Animas River is shown in Table 3.19. These computations demonstrate that discharge from the fault and bedrock has a negligible effect on the Animas River water quality. 
Table 3.19 Computed change in Animas River water quality due to ground water discharge from the raffinate ponds area, Durango, Colorado, site ${ }^{a}$

\begin{tabular}{|c|c|c|c|}
\hline $\begin{array}{c}\text { Contaminant } \\
\text { of potential } \\
\text { concern } \\
\end{array}$ & $\begin{array}{c}\text { Maximum observed } \\
\text { concentration in } \\
\text { ground water }\end{array}$ & $\begin{array}{c}\text { Computed change in } \\
\text { surface water } \\
\text { caused by ground } \\
\text { water discharge } \\
\end{array}$ & $\begin{array}{l}\text { Average concentration } \\
\text { in filtered samples of } \\
\text { Animas River surface } \\
\text { water upstream of site }\end{array}$ \\
\hline Ammonium & 3.3 & 0.001 & NA \\
\hline Antimony & $0.196^{d}$ & 0.00006 & NA \\
\hline Arsenic & 0.04 & 0.00001 & 0.004 \\
\hline Cadmium & 0.0009 & 0.0000003 & 0.0002 \\
\hline Calcium & 491 & 0.2 & 61 \\
\hline Chloride & 2400 & 0.7 & 11 \\
\hline Fluoride & 0.4 & 0.0001 & 0.3 \\
\hline Iron & $3.0^{d}$ & 0.0009 & $<0.05$ \\
\hline Lead & 0.07 & 0.00002 & 0.001 \\
\hline Magnesium & 724 & 0.2 & 10 \\
\hline Manganese & 7.3 & 0.002 & 0.06 \\
\hline Molybdenum & 0.1 & 0.00003 & $<0.01^{e}$ \\
\hline Nickel & 0.025 & 0.000008 & $<0.005$ \\
\hline Potassium & 82 & 0.02 & 2 \\
\hline Selenium & 0.08 & 0.00002 & 0.007 \\
\hline Silica & 24.9 & 0.007 & NA \\
\hline Silver & $<0.01$ & $<0.000003$ & $<0.0002$ \\
\hline Sodium & 4600 & 1 & 13 \\
\hline Sulfide & 0.3 & 0.00009 & NA \\
\hline Sulfate & 10,000 & 3 & 113 \\
\hline Thallium & 0.06 & 0.00002 & NA \\
\hline Tin & $0.133^{d}$ & 0.00004 & NA \\
\hline Uranium & 0.57 & 0.0002 & $<0.005$ \\
\hline Vanadium & 0.06 & 0.00002 & NA \\
\hline Zinc & 0.025 & 0.000008 & 0.014 \\
\hline
\end{tabular}

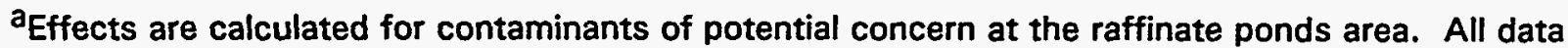
are in milligrams per liter.

bMaximum concentration observed in ground water from the raffinate ponds area between May 1990 and June 1994. Values are for filtered ground water samples, unless otherwise noted.

${ }^{c}$ Average concentration for filtered surface waters collected monthly from January 1993 through June 1993. BOR data, unless otherwise noted. Refer to Table 3.17.

dValue is for unfiltered ground water sample.

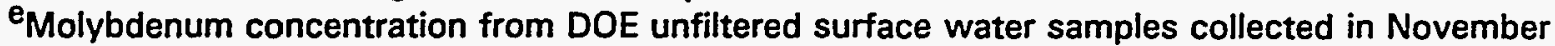
1993.

NA - not analyzed. 


\subsection{EXPOSURE ASSESSMENT}

The two areas where different stages of uranium ore processing took place are evaluated separately at the Durango site: the uranium mill tailings and raffinate ponds areas. At the mill tailings area, most of the ground water contamination is in the alluvium/colluvium, which will be referred to as the shallow aquifer. At the raffinate ponds area, the most contaminated ground water is in the Menefee and adjacent fault.

\subsection{POTENTIALLY EXPOSED POPULATION}

Exposure can occur only if there are both a source of contamination and a mechanism of transport to a receptor population or individual. Ground water contaminated by uranium ore processing at the former processing site at Durango is not currently used. As shown in Figure 2.9, ground water is not withdrawn within $2 \mathrm{mi}(3 \mathrm{~km})$ downgradient of the site. Area residents living within the city limits use water supplied by the municipal water system, which obtains water from the Florida and Animas Rivers. Although a number of residents located northwest of the site have domestic wells completed in the shallow aquifer, their upgradient location prevents contaminant migration to these wells. Ground water in the site area discharges to the Animas River, where it is quickly diluted (refer to Section 3.6).

Although plans for future land use do not specify residential developments at the site, such land uses cannot be precluded. Therefore, it is assumed that in the future, a domestic well could be installed in the contaminated aquifer at the mill tailings or raffinate ponds areas, creating the potential for exposure through drinking, bathing, and irrigation. However, the likelihood of residential development at the mill tailings or raffinate ponds areas is considered to be low.

The future scenario evaluates domestic ground water use consistent with current water uses by the population in the region. The potentially exposed population includes residents of the following age groups: infants (birth to 1 year old); children ( 1 to 10 years old), and adults ( 11 to 65 years old). These age groups were selected for the following reasons:

- Survey data for population variables such as age, weight, and daily water intake are available for these age groups.

- Toxicological variables are similar within these age groups, including responsiveness of sensitive subgroups (infants, children, and adults) to the contaminants of potential concern, toxicant intake-to-body-weight ratios, and toxicokinetics.

Some individuals and/or subpopulations could be more vulnerable to potential exposures than the general population. These sensitive subpopulations could include children, the elderly, or people with existing illness, such as diabetes. 
Another sensitive subpopulation would include individuals whose intake of certain contaminants is already higher than national averages.

\subsection{EXPOSURE PATHWAYS}

An exposure pathway describes the course a contaminant takes from a source to an exposed individual. Exposure can occur only if there are a source of contamination, a point of contact with a population or individual, and a route of exposure (e.g., water ingestion). Because the tailings piles and soils contaminated from uranium milling operations at the site were removed and relocated to a disposal cell, soil or air exposure pathways (such as incidental soil ingestion, dermal contact with soil, or inhalation of particulates) are not considered. This assessment evaluates both ground water and surface water/sediment pathways. Water in the region is used primarily for household purposes such as drinking, cooking, and bathing. Another ground water use typical of the region, which could lead indirectly to human exposure, is irrigation. Recreational fishing and hunting can form additional potential exposure pathways. Figure 4.1 provides a conceptual model of the potential ground water and surface water/sediment exposure pathways that are believed to lead to the greatest exposure potential at the Durango site. Pathways that are not considered in this model include exposure to soil contaminated via irrigation or migration of contaminants from ground water to soil (for example, inhalation of fugitive dust and incidental soil ingestion). Preliminary calculations demonstrate that the sum of these pathways typically contributes much less than exposure from drinking water ingestion (TAC, 1995). Under some land uses or construction activities, these pathways constitute a significant exposure. Upon determination of a specific land use or construction activity, these pathways might require additional evaluation.

\subsubsection{Drinking water ingestion}

Although it is unlikely that ground water at the site will be used in the future for drinking purposes because of the availability of a municipal water supply system, this risk assessment will evaluate a hypothetical future use of the ground water at the mill tailings and raffinate ponds areas.

Drinking water ingestion is generally the most significant exposure route for ground water contaminated with metals and other nonvolatile compounds (DOE, 1994). In this evaluation, drinking water consumption includes amounts of water ingested by drinking and amounts of water used for food preparation (e.g., reconstituted juices, soup, rice, and beans).

Because drinking water ingestion is typically the dominant pathway, it is the only pathway evaluated quantitatively in Section 4.4. A probabilistic evaluation has been conducted for cadmium, manganese, molybdenum, selenium, sodium, sulfate, uranium, and vanadium detected in ground water at the mill tailings area, and for chloride, manganese, sodium, sulfate, and uranium detected in ground water at the raffinate ponds area. Additional contaminants of potential 


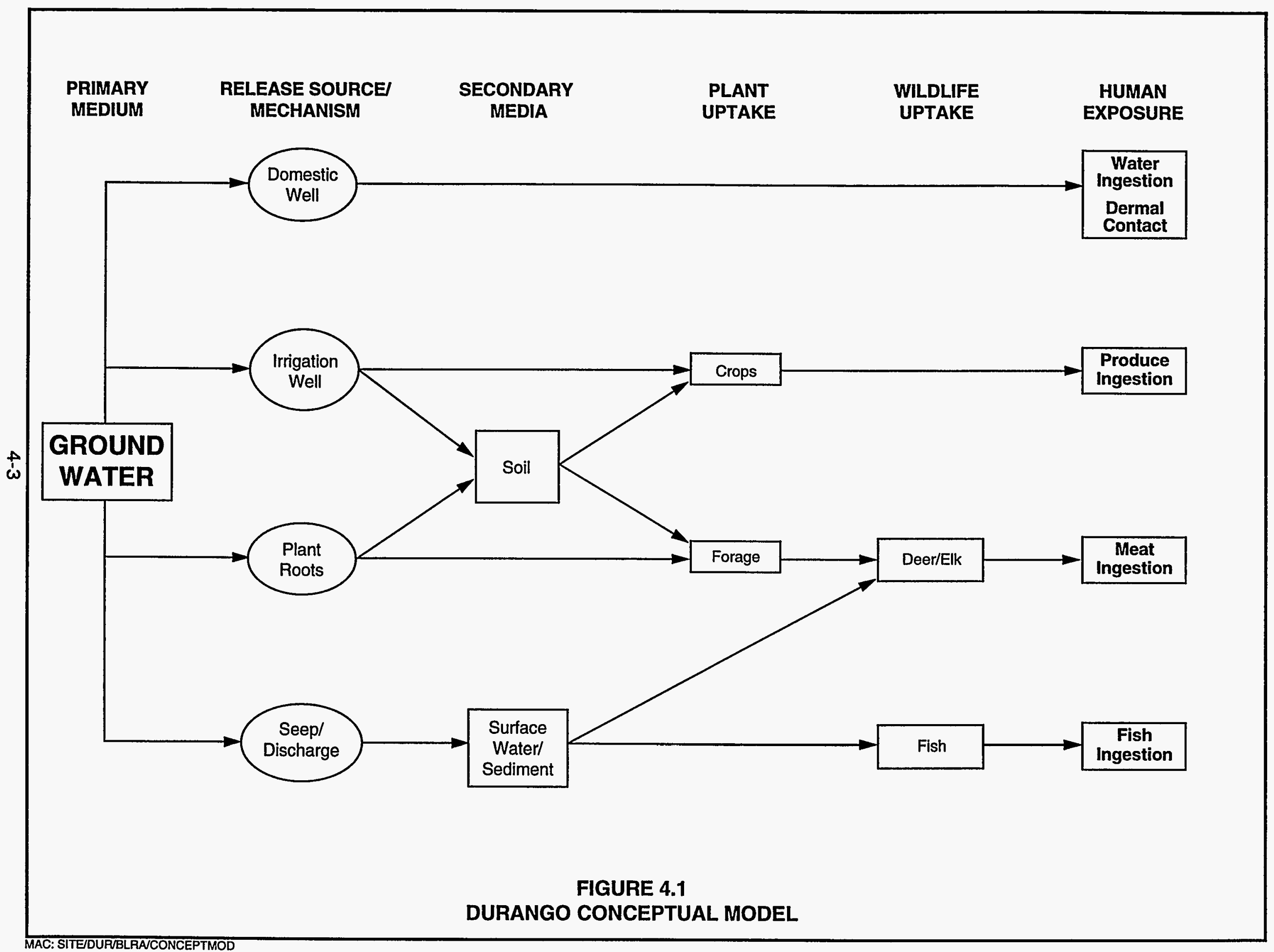


concern that do not have a sufficient database to generate probability distributions to describe plume water concentrations or have not been analyzed for in background monitor wells are evaluated in Section 6.1 using exposure point concentrations.

\subsubsection{Dermal absorption}

Dermal absorption is the process by which chemicals coming into contact with the skin become absorbed into the blood vessels near the skin surface. Although some compounds are absorbed easily in this manner, metals are generally poorly absorbed through intact skin.

To evaluate this exposure route, a screening calculation was performed to determine whether the exposure contribution from dermal absorption would be significant compared to the drinking water ingestion exposure route for the contaminants of potential concern (TAC, 1995). Because chemical-specific absorption factors are not available for these contaminants, they are assumed to absorb across intact skin at the same rate as water. This assumption probably will overestimate the potential exposure contribution from dermal absorption.

Although the dermal dose is an absorbed dose, and only a percentage of the ingested dose will be absorbed, the very low (0.2 percent) exposure contribution of dermal absorption is assumed to be insignificant compared to ingestion. Because the assumptions used to estimate the dermal absorption exposure dose are believed to overestimate exposure (metals are assumed to be absorbed like water) and because the dose is less than a 1 percent incremental contribution to the exposure dose from drinking water ingestion, this pathway is not further evaluated in this risk assessment.

\subsubsection{Produce ingestion}

Contaminants in ground water could be taken up by plants either through roots in soil saturated with contaminated ground water or from irrigation water obtained by a well in the contaminated ground water. These plants could be eaten by humans or could enter the food chain and subsequently be consumed in the form of meat, as discussed in Section 4.2.4. The amount this exposure route could contribute could be significant if the contaminants concentrate in plants. There are currently not enough data to evaluate this potential contribution based on literature values. However, the UMTRA Ground Water Project is currently studying contaminant uptake by irrigated vegetables and grasses. When these data become available, this pathway will be evaluated for this site and the results will be included in the site environmental assessment or environmental impact statement. If applicable, these data will also be considered in the development of a ground water compliance strategy for the site.

An evaluation of the potential damage to plants from contaminated water is presented in Section 7.0. 


\subsubsection{Meat ingestion}

Contaminants in ground water can enter the food chain when animals consume ground water that has reached the land surface or when animals consume plants that have taken up contaminants through roots tapping contaminated ground water. This exposure route is considered feasible because elk and deer habitats are adjacent to the site and hunting is permitted. As with plant uptake, there are not sufficient data available in the literature to quantitatively evaluate this pathway. The results of the plant uptake studies and additional site characterization will enable this pathway to be better characterized. These results will be included in the site environmental assessment or environmental impact statement and will be considered in the ground water compliance strategy, if applicable.

An evaluation of the direct toxicity of contaminants to wildlife is presented in Section 7.0.

\subsubsection{Fish ingestion}

Recreational fishing in the Animas River near the site is common. Because the contaminated ground water from the site discharges to the Animas River and because contaminants may remain in sediments and cycle through biota, this pathway is considered.

In 1992, the BOR collected fish from the Animas River. Two of the areas sampled are in the vicinity of Durango. From these areas, 12 rainbow trout, 12 brown trout, 10 flannelmouth sucker, 6 bluehead sucker, 21 mottled sculpin, and 3 carp were analyzed for 32 inorganics (whole body analysis; not including uranium) (TAC, 1995).

When compared to national averages, the data indicated that there may be elevated levels of certain metals such as cadmium (up to 4 times the national average) and lead (up to 30 times the national average). These concentrations and values for antimony, arsenic, iron, and manganese could be toxicologically significant if they are representative of edible tissue and if fish are ingested regularly.

Whether the former processing site is a contributing factor in these levels cannot be determined. Metals present in fish may come from naturally occurring ore deposits, mining sites, other milling operations, and industrial discharges known to occur, or to have historically occurred, along the Animas River. This complex mixture of discharges, coupled with tremendous uncertainty regarding the habitat ranges of the fish over their lifespan, make a potential connection of fish tissue levels with any one site contaminant difficult to determine. Because of these factors, the fish ingestion pathway is not evaluated in this risk assessment. Nonetheless, it is noted here because of the potential for additive exposure contribution. Regardless of the source of metals in the fish, fish ingestion represents a potential exposure route that could 
increase dietary levels of the contaminants of potential concern in people who eat fish. As such, this exposure could increase the potential toxicity from exposure from other pathways considered in this risk assessment. This incremental exposure is further discussed in Section 6.1 .

\subsection{EXPOSURE CONCENTRATIONS}

The exposure concentration of a contaminant in ground water is that concentration contacted by an individual over the period of exposure being considered. In this evaluation, the contaminant concentrations land therefore exposures) are assumed to be in a steady state, even though actual exposure concentrations are expected to fluctuate and eventually decrease with time because the surface of the site has been cleaned up. Nonetheless, they are reasonable estimates for chronic exposure soon after surface remediation. Chronic exposure for noncarcinogens is considered to be any period longer than 7 years. For carcinogens, a lifetime exposure over 30 years is considered.

Exposure concentrations are evaluated as a probability of occurrence for cadmium, manganese, molybdenum, selenium, sodium, sulfate, uranium, and vanadium at the mill tailings area, and for chloride, manganese, sodium, sulfate, and uranium for the raffinate ponds area. This evaluation is based on ground water data collected from the most contaminated monitor wells at the mill tailings and raffinate ponds areas. Tables 3.2 and 3.8 show the maximum observed concentrations used to evaluate the toxicity and/or carcinogenicity of contaminants of potential concern that could not be evaluated probabilistically because it could not be determined whether these contaminants occur above background levels. These maximum observed concentrations of antimony and lead in ground water from the mill tailings area and of antimony, arsenic, cadmium, lead, molybdenum, selenium, and thallium in ground water from the raffinate ponds area represent the exposure point concentrations used to estimate intakes and evaluate risks in Section 6.0.

For the mill tailings area, ground water quality data based on filtered samples from monitor well DUR-01-612 are used. With one exception, this well has consistently shown the highest levels of contamination through the past 4 years of monitoring. Selenium levels were historically higher in well DUR-01-617 than in well DUR-01-612; therefore, the analysis of selenium toxicity is conducted based on concentrations observed in well DUR-01-617. For antimony, lead, and radionuclides, the maximum observed concentration or activity in any filtered or unfiltered sample collected between 1990 and 1994 is used. The highest level of antimony was observed in the filtered ground water sample from monitor well DUR-01-612; therefore, the analysis of antimony toxicity is performed based on the maximum observed concentration in that well. Lead levels measured in unfiltered samples from monitor well DUR-01-617 were higher than in well DUR-01-612; thus, lead toxicity is analyzed based on the maximum observed concentration in well DUR-01-617. Lead-210 and radium-226 activities were the highest in unfiltered samples from well DUR-01-612; therefore, the analyses of carcinogenic potential of lead-210 and radium-226 are based on the 
maximum observed activities in that well. Maximum observed activities measured in unfiltered ground water samples from well DUR-01-617 are used for polonium-210 and thorium-230.

For the raffinate ponds area, no single monitor well has consistently shown the highest levels of contamination between 1990 and 1994. Manganese and sodium levels were consistently higher in well DUR-02-593 than in other downgradient wells; therefore, manganese and sodium toxicities are analyzed based on concentrations observed in well DUR-02-593. Uranium concentrations were consistently higher in well DUR-02-598 than in other downgradient wells; thus, uranium toxicity is evaluated based on concentrations observed in that well. Sulfate levels were consistently higher in monitor wells DUR-02-593 and -598 than in well DUR-02-602; therefore, sulfate toxicity is evaluated based on concentrations observed in combined wells DUR-02-593 and -598 . Chloride levels measured in downgradient wells DUR-02-593, -598 , and -602 are combined to characterize the probable distribution of chloride concentrations in the contaminated ground water, because no single well had sufficient measurements from which to build a distribution. For antimony, arsenic, cadmium, lead, molybdenum, selenium, thallium, and the longer-lived progeny of the uranium decay series, the maximum observed concentration or activity in any filtered or unfiltered sample collected between 1987 and 1994 was used. Arsenic, cadmium, lead, molybdenum, selenium, and thallium levels were higher in filtered samples from monitor well DUR-02-602 than from other wells; therefore, toxicities of these contaminants are evaluated based on the maximum observed concentration in filtered samples from well DUR-02-602. Antimony concentrations were the highest in unfiltered samples from well DUR-02-602; therefore, the analysis of antimony toxicity is conducted based on the maximum observed concentration in unfiltered samples from that well. Lead-210 and polonium-210 activities were consistently measured in unfiltered samples from monitor wells DUR-02-598 and -602; thus, lead-210 and polonium-210 carcinogenicity is evaluated based on the maximum observed activity in combined monitor wells DUR-02-598 and -602 . Finally, radium-226 and thorium-230 maximum observed activities in unfiltered samples from combined downgradient wells DUR-02-593, -598 , and -602 are used to evaluate radium-226 and thorium-230 carcinogenicity.

Carcinogenic effects associated with exposure to radium-226, lead-210, polonium-210, and thorium-230 at the mill tailings and raffinate ponds areas are evaluated in Section 6.0.

The probability distribution selected for a contaminant had the same mean and standard deviation and approximately the same shape as were observed in the actual water quality data (TAC, 1995). The tails of the distributions were truncated below $0.0 \mathrm{mg} / \mathrm{L}$ and above the 99 th percentile. The probability associated with the disallowed portion was assigned proportionally to the allowable values, so that the total probability under the truncated curve remained equal to 1.0. The truncation at the upper end of the distribution is an attempt to place a reasonable upper limit on potential future exposures. The 

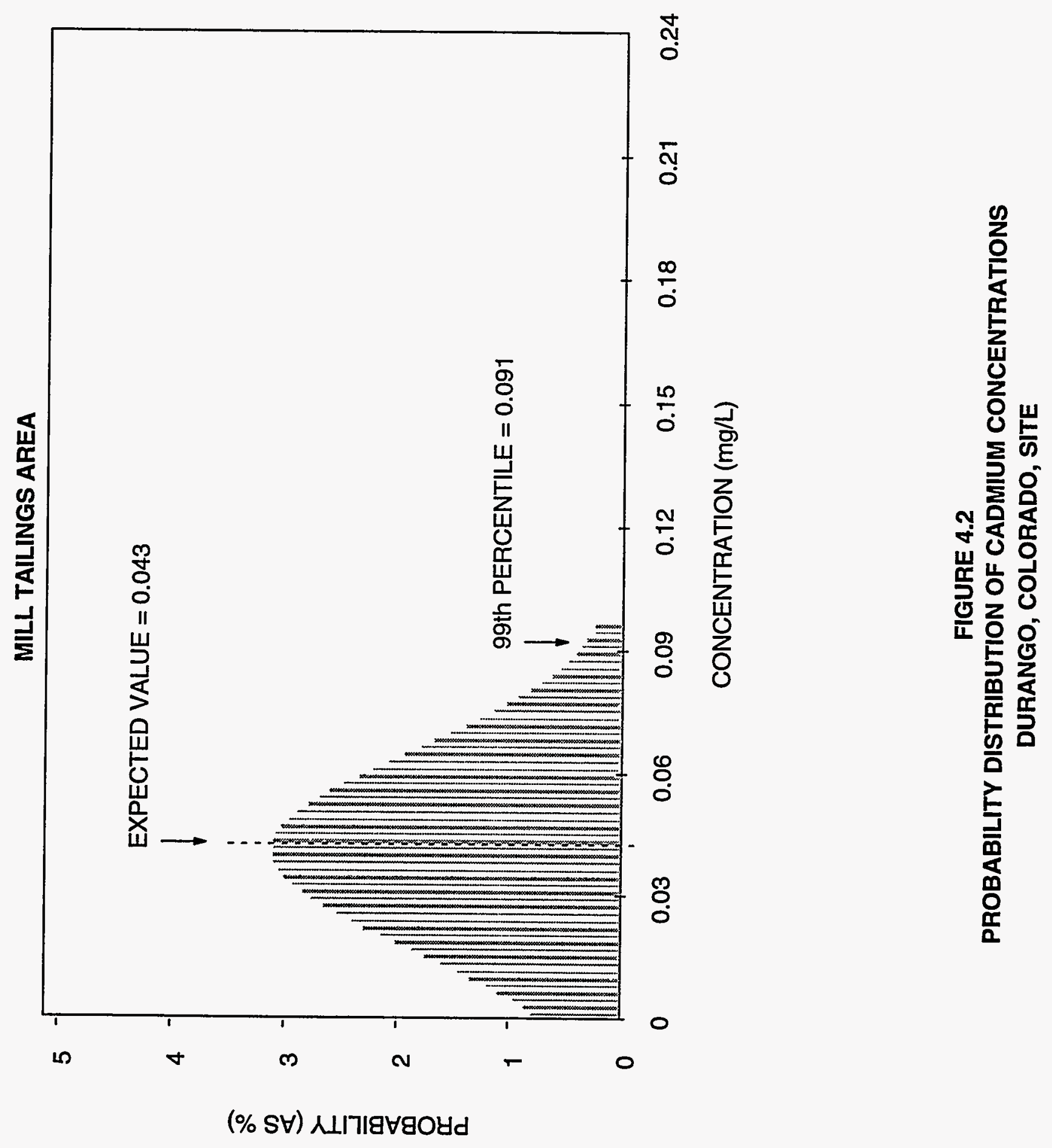

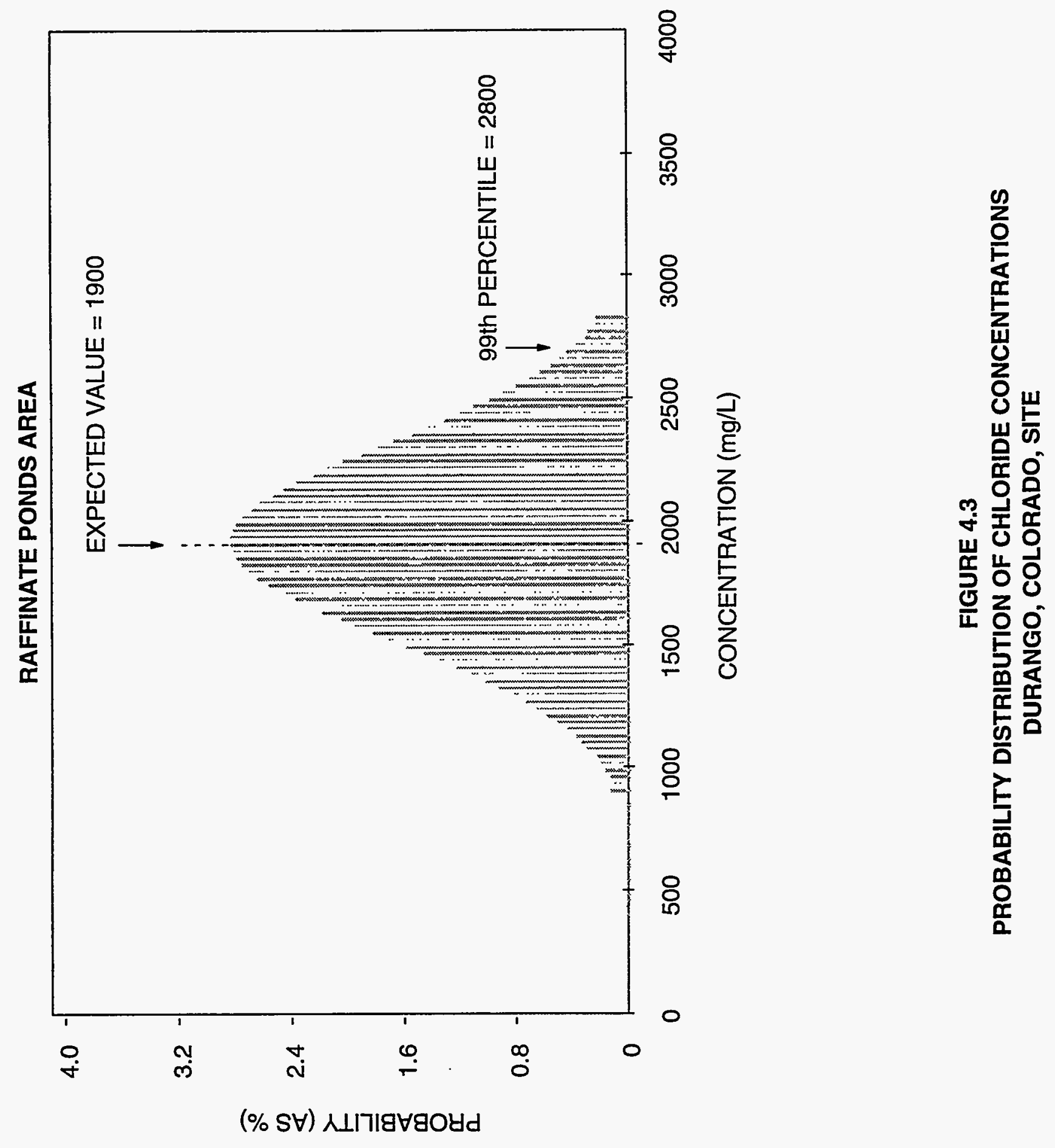

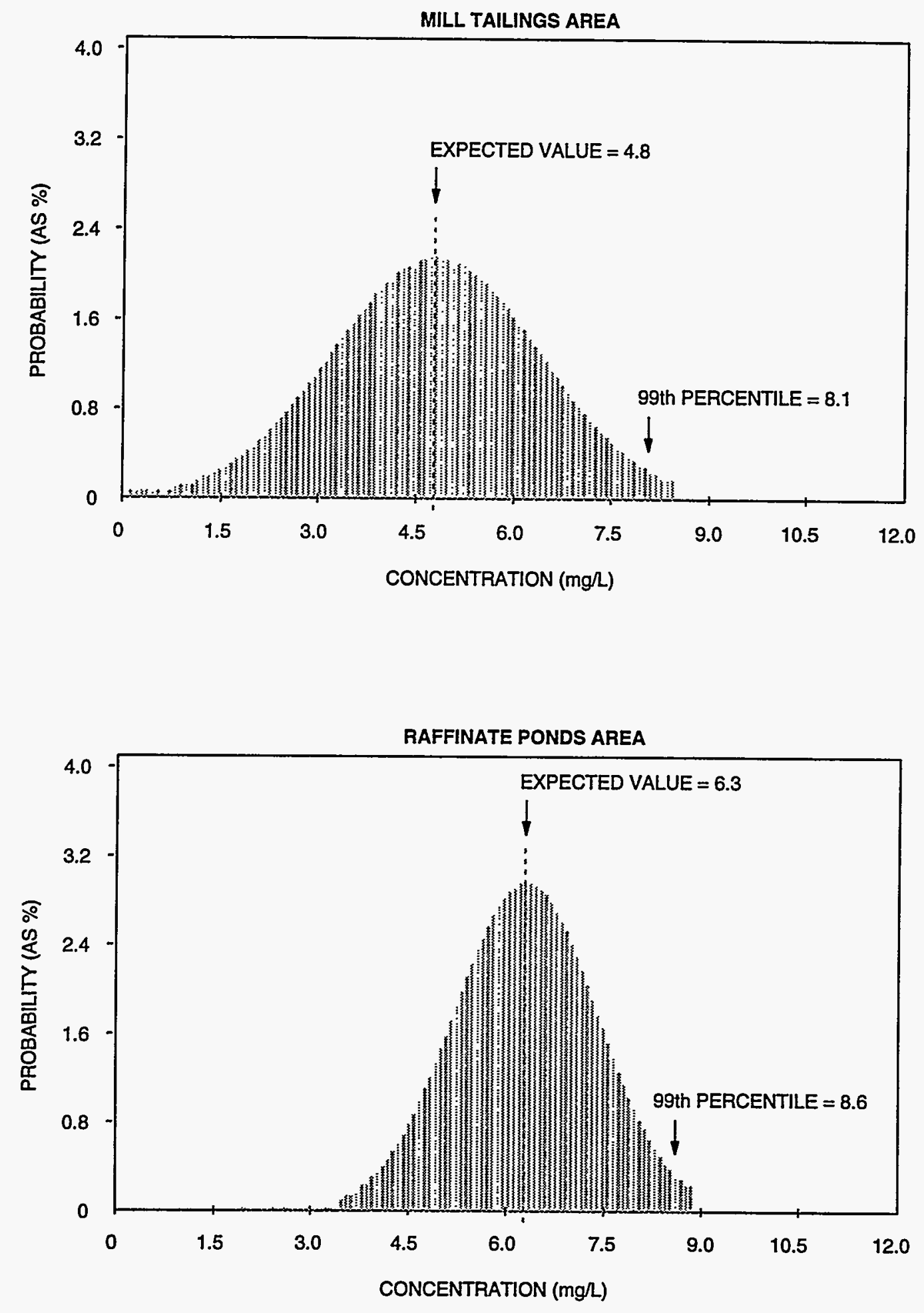

FIGURE 4.4

PROBABILITY DISTRIBUTION OF MANGANESE CONCENTRATIONS DURANGO, COLORADO, SITE 

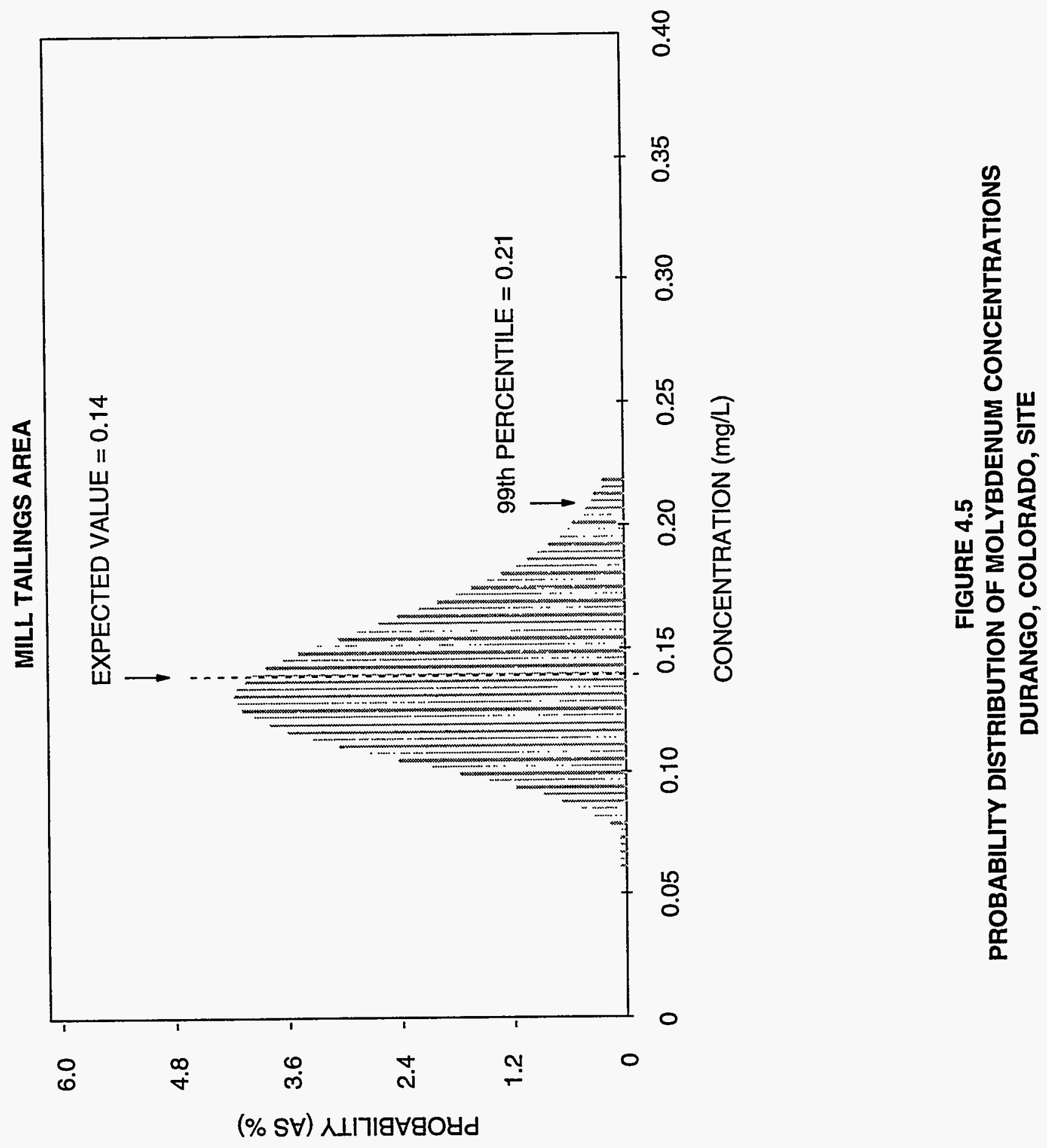

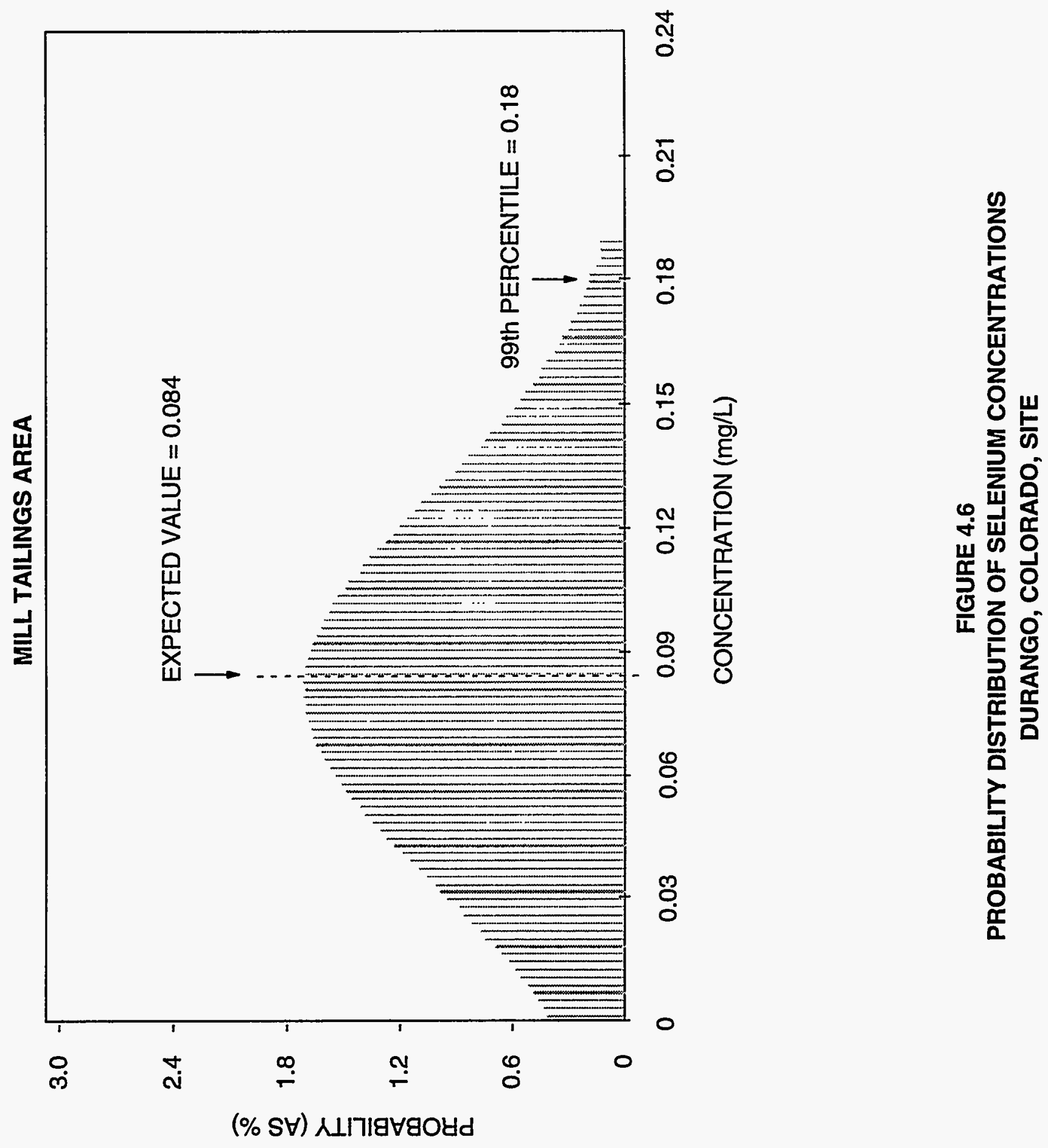
MILL TAILINGS AREA

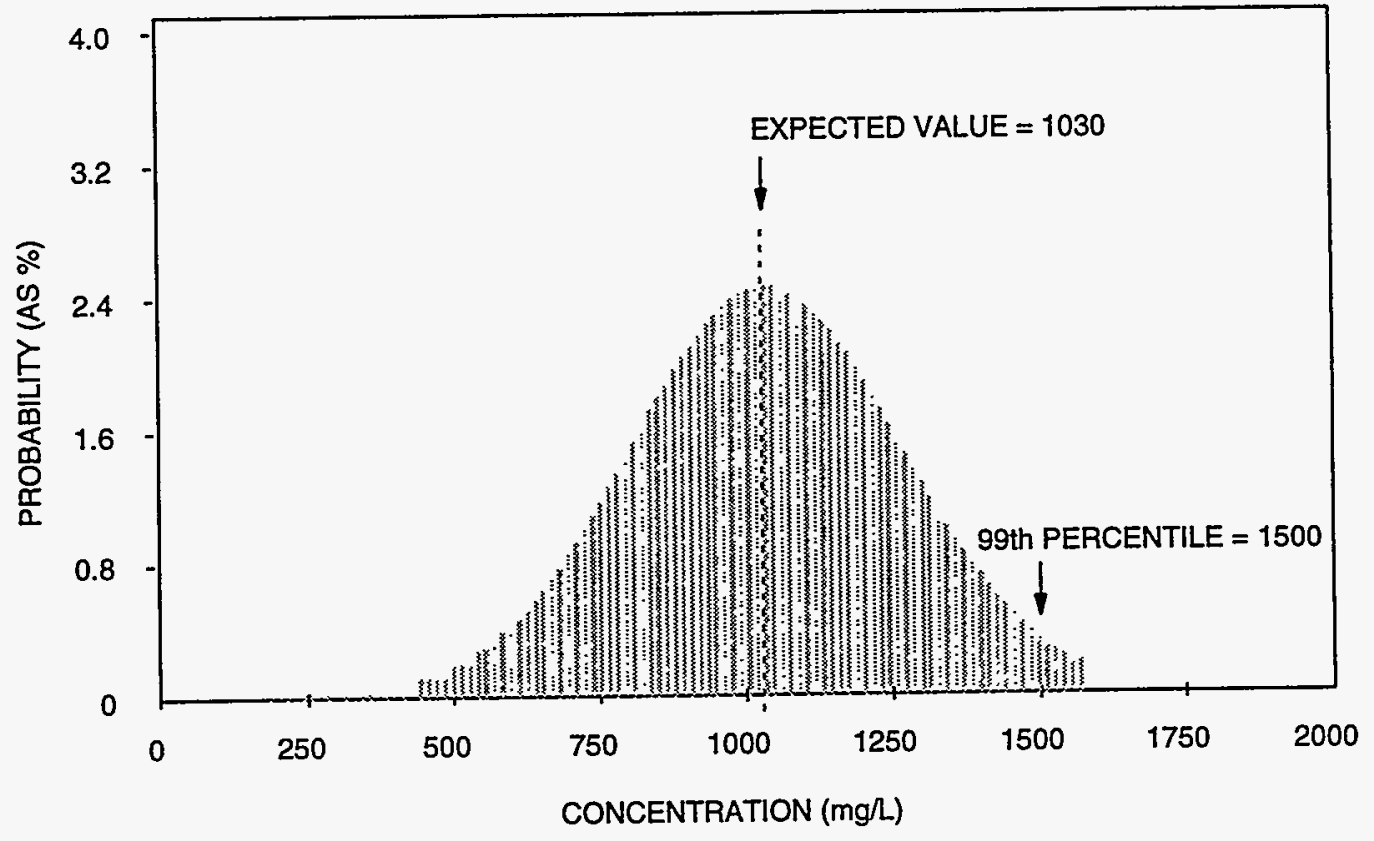

RAFFINATE PONDS AREA

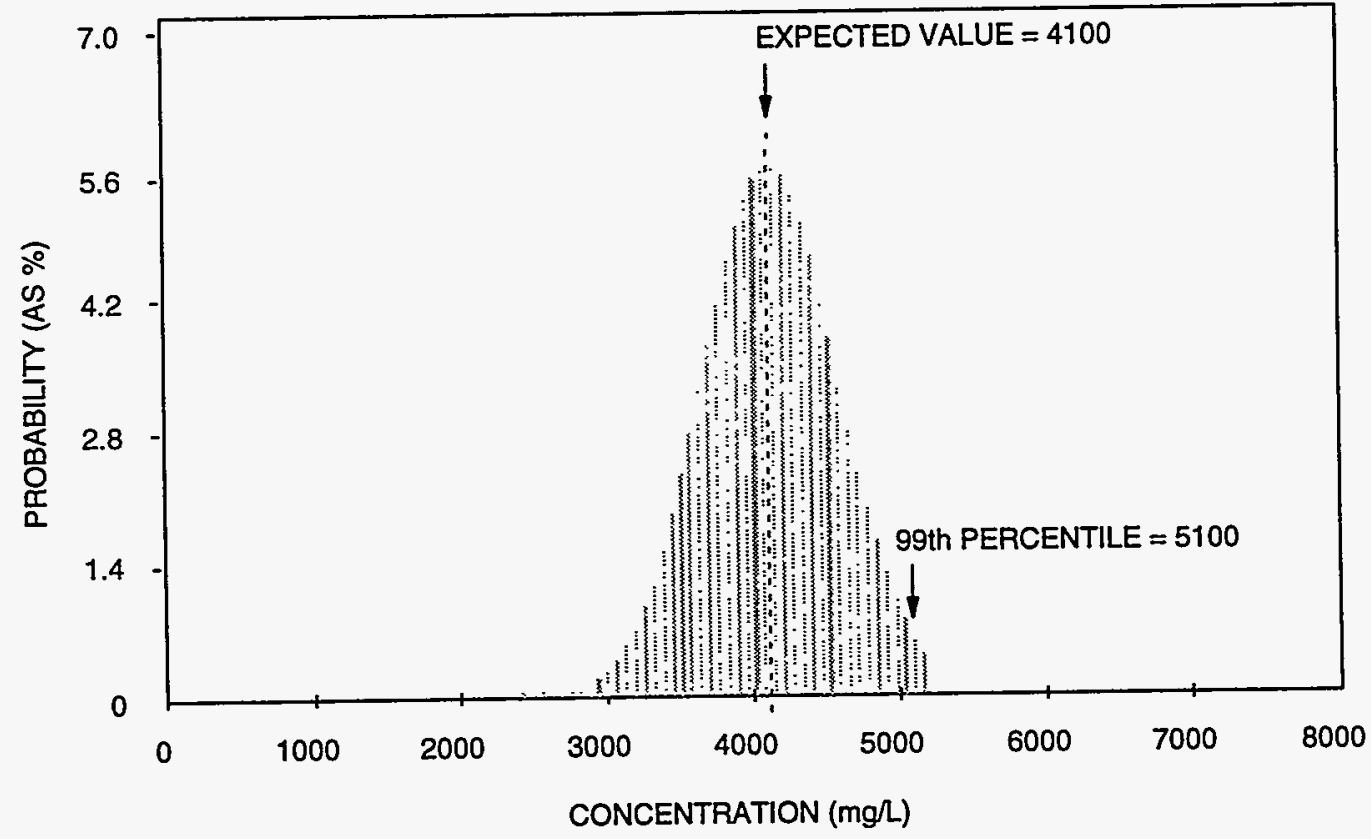

FIGURE 4.7

PROBABILITY DISTRIBUTION OF SODIUM CONCENTRATIONS

DURANGO, COLORADO, SITE 

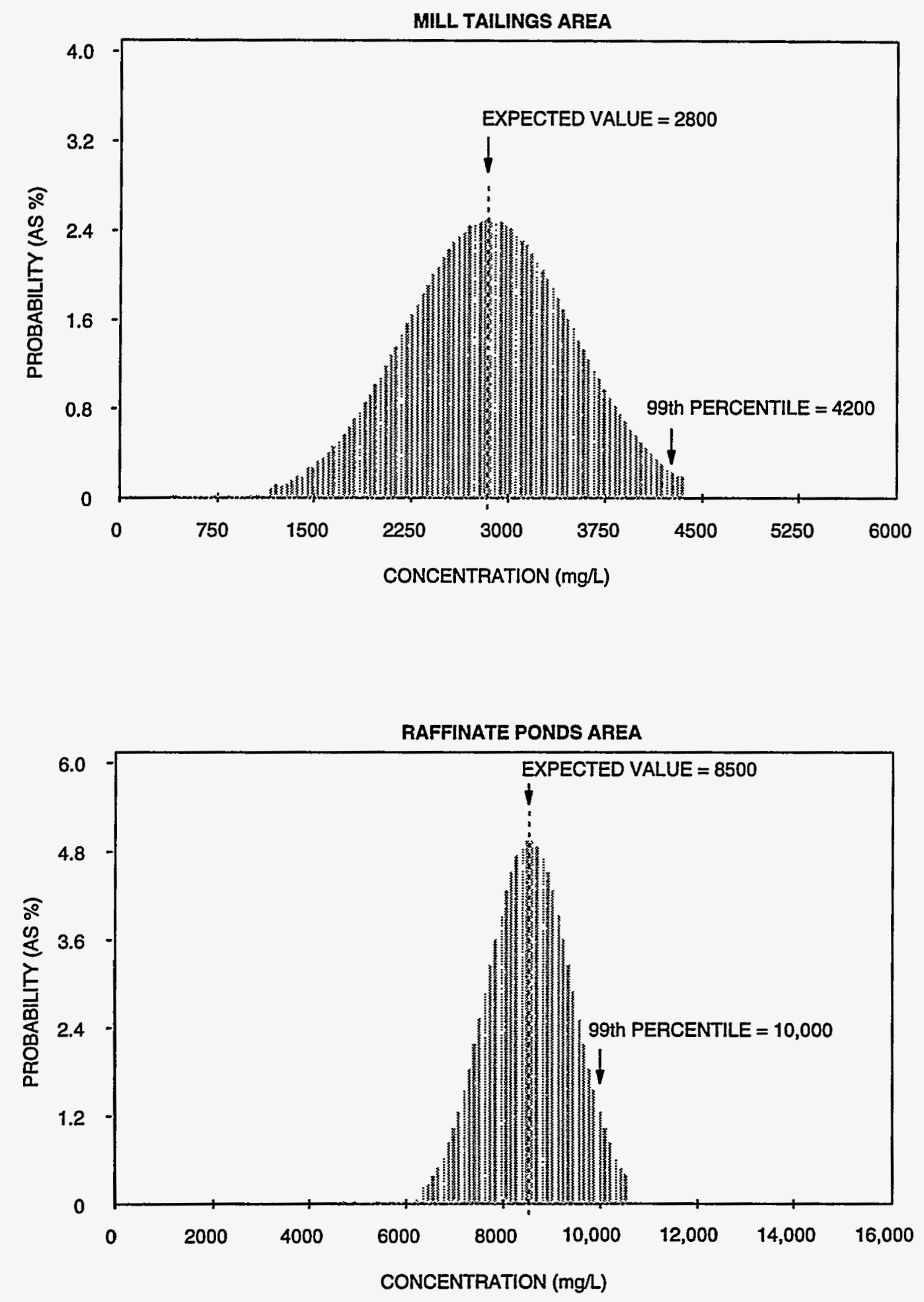

FIGURE 4.8

PROBABILITY DISTRIBUTION OF SULFATE CONCENTRATIONS DURANGO, COLORADO, SITE 
MILL TAILINGS AREA

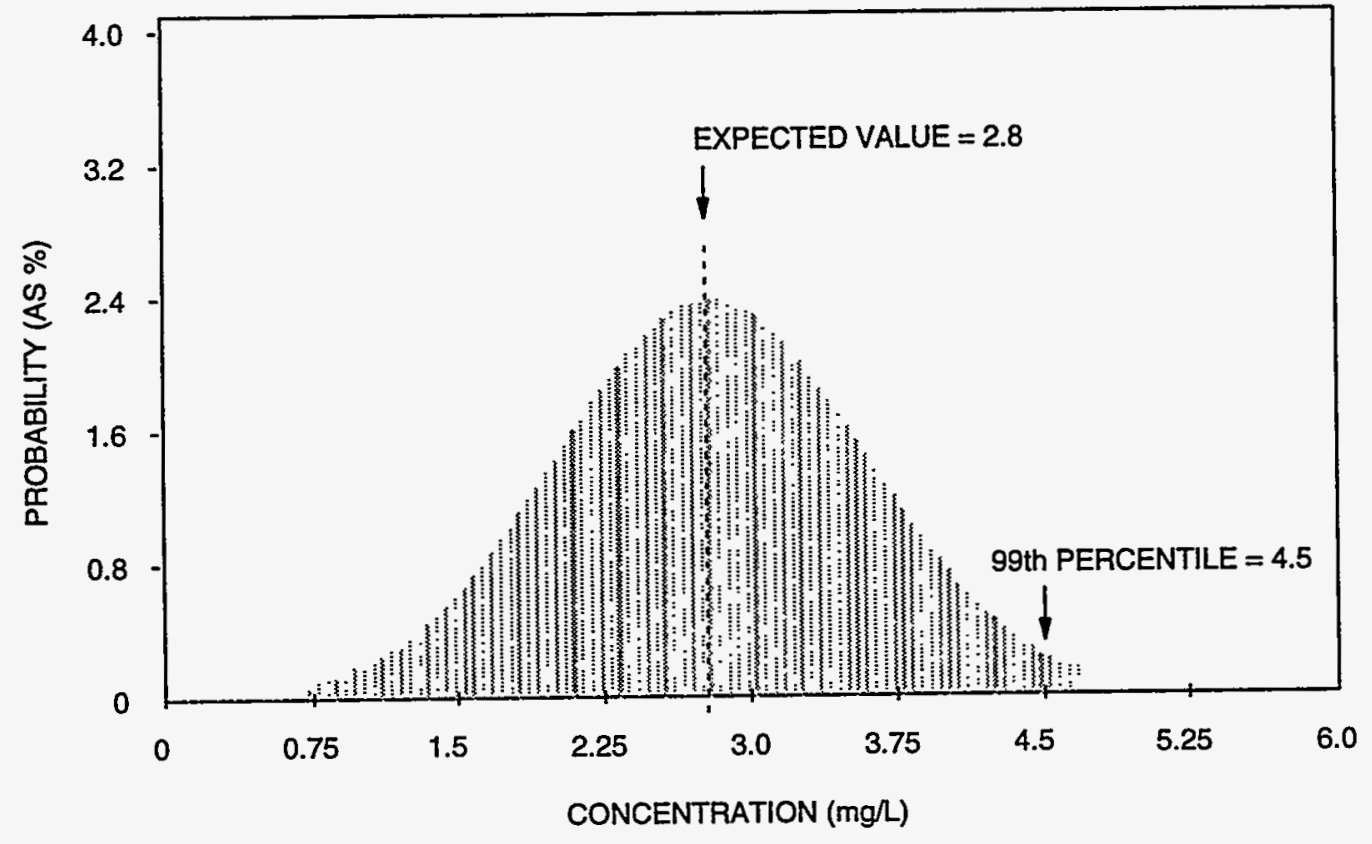

RAFFINATE PONDS AREA

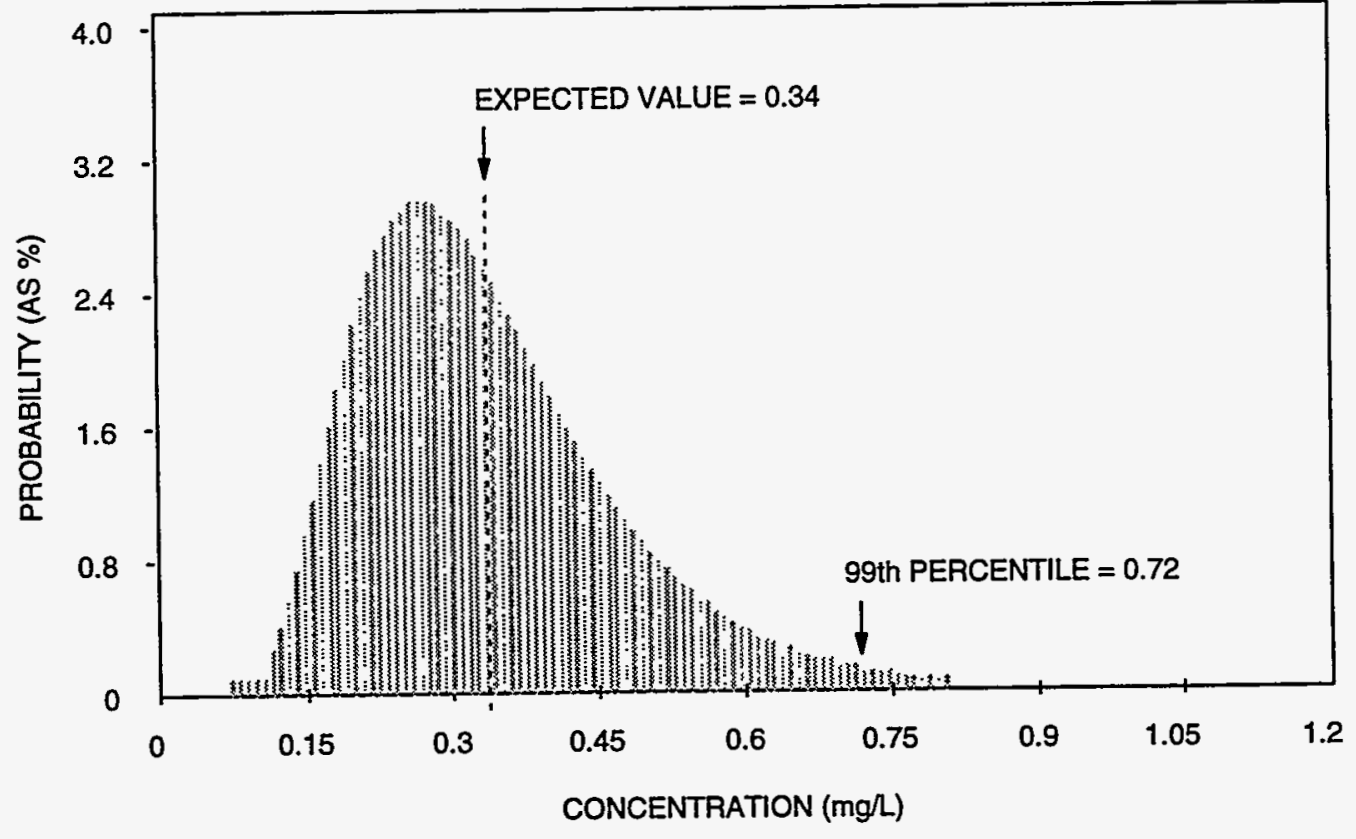

FIGURE 4.9

PROBABILITY DISTRIBUTION OF URANIUM CONCENTRATIONS DURANGO, COLORADO, SITE 

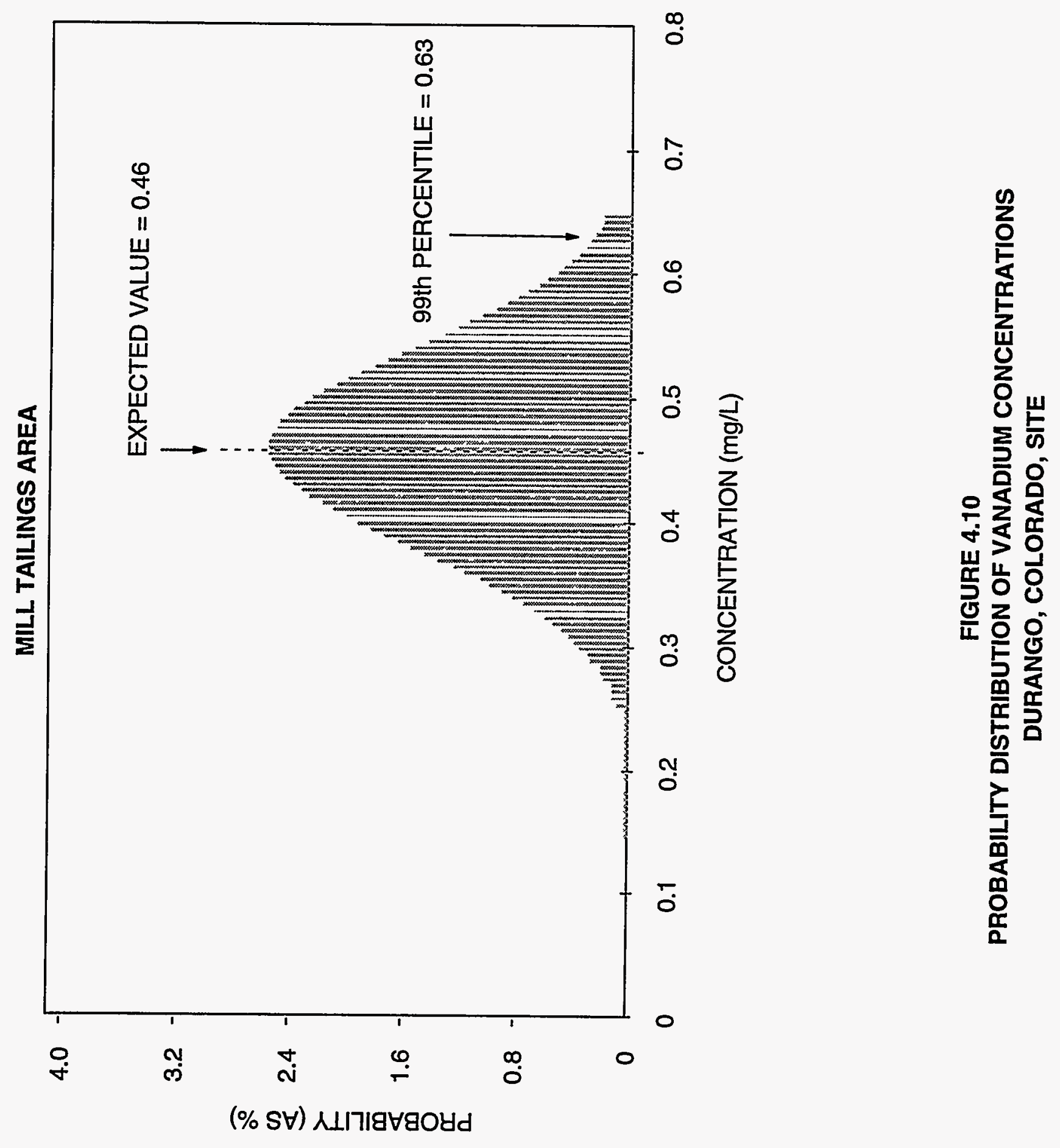
The potential carcinogenicity of radionuclides is thought to increase with total intake over time, instead of with average daily intake as for noncarcinogens. Also, body weight is relatively insignificant in determining risk from exposure. Intake of radionuclides is therefore quantified as total exposure to radioactivity through the residency period of an individual:

(3)

$$
\begin{aligned}
& \text { Intake }=\text { Concentration } x \text { Ingestion rate } x \text { Exposure duration } x \text { Exposure frequency } \\
& (\mathrm{pCi} / \text { lifetime })=\underset{(\mathrm{pCi} / \mathrm{L})}{\text { (L/day) }} \times \underset{\text { (years) }}{\text { Coys/year) }}
\end{aligned}
$$

\section{Average daily intake (liters per day)}

Lognormal probability distributions were used to describe variations in average daily tap water intake among members of the population (Roseberry and Burmaster, 1992). These distributions were developed from data collected during a 1977-1978 food consumption survey conducted by the U.S. Department of Agriculture. During the survey, total tap water consumption during a 3-day period was recorded for 26,081 survey participants nationwide (Figure 4.11).

\section{Body weight (kilograms)}

Extensive national data on weights of males and females, by age, were collected during a health and nutrition survey conducted from 1976 to 1980 . These data were used to develop lognormal probability distributions for body weight by age and separately by gender. The distributions for males and females were then combined using census data on the national ratio of males and females within each age group (Figure 4.12).

\section{Exposure frequency (days per year)}

Individuals generally are not present at their homes and drinking water from the same source for $\mathbf{3 6 5}$ days per year. Therefore, calculation of intake assumes only 350 days of exposure per year, allowing for 15 days per year of drinkingwater intake from a different source. Because exposure is expressed and compared in terms of average daily intake, 365 days per year is retained in the averaging-time term in the denominator.

\section{Exposure duration (years)}

Distributions of exposure duration were developed using data collected by the U.S. Department of Commerce, the Bureau of the Census, and the U.S. Department of Housing and Urban Development in 1985 and 1987 (Israeli and Nelson, 1992). For noncarcinogenic effects, the exposure duration in the numerator and denominator of the drinking water intake equation (see equation (1)) cancel out, assuming all exposures are chronic (i.e., at least 7 years). Thus, deviations from the standard residence time assumptions do not affect the results. However, for carcinogenic effects of arsenic, uranium, and other radionuclides, risk is cumulative throughout a lifetime; therefore, deviations from the hypothesized residency distribution could significantly affect the risk 

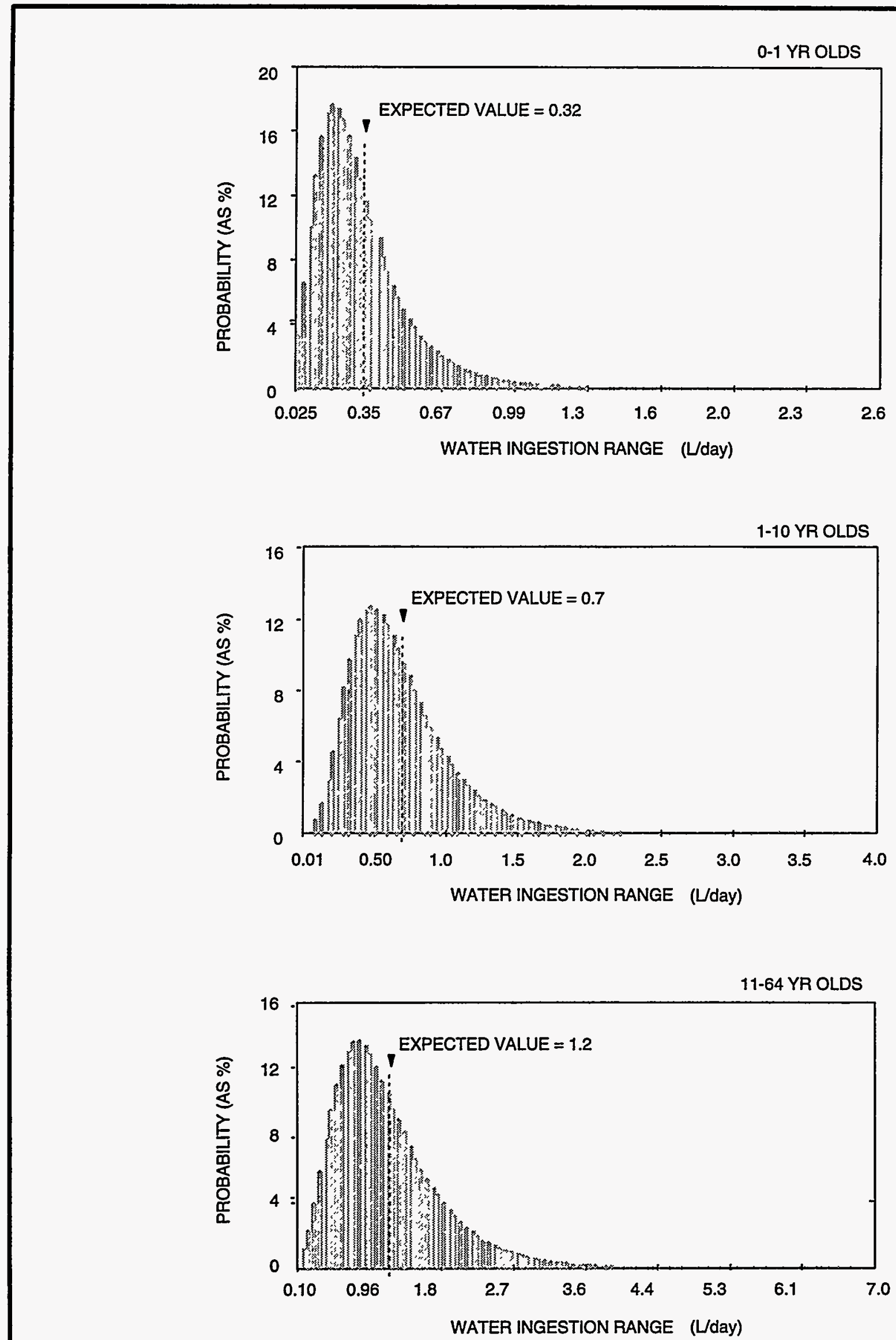

FIGURE 4.11

PROBABILITY DISTRIBUTIONS FOR TAP WATER INGESTION RATES 

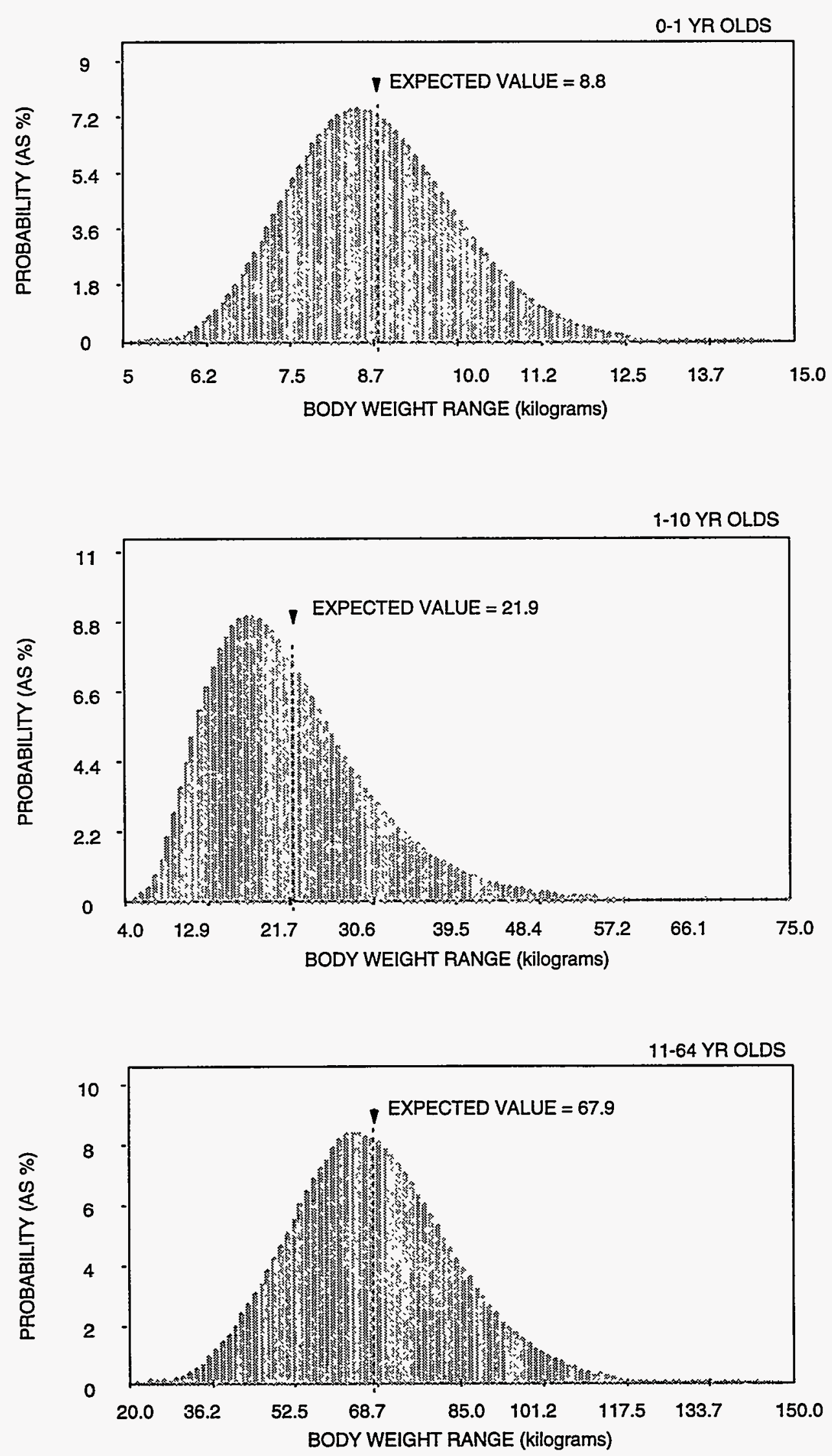

FIGURE 4.12

PROBABILITY DISTRIBUTIONS FOR BODY WEIGHT 
estimate. Because Durango is a small urban center where some mobility would be expected, a fixed lifetime exposure of 30 years was used to estimate lifetime cancer risks.

Using exposure concentration distributions discussed in Section 4.3 and the intake parameter distribution from this section, total intake distributions were simulated for the three age groups (0- to 1-, 1- to 10-, and 11-to 65-year-olds) using the @RISK software package (Palisade Corp., 1992) and 10,000 iterations. The 1-to 10-year-old group consistently showed the highest intaketo-body-weight distributions (Figure 4.13) and therefore is the most conservative age group to evaluate. This age group is likely more susceptible to metals toxicity than adults because of higher gastrointestinal absorption efficiency and other toxicokinetic factors (Casarett and Doull, 1991). However, because infants are the most sensitive group for sulfate toxicity, the intake distributions for this age group (i.e., age 0 to 1 year) are used for this contaminant. Simulated intake distributions for appropriate age groups for contaminants of potential concern evaluated probabilistically are presented in Figures 4.13 through 4.21 . The intake estimates used to calculate the hazard index and carcinogenic risk are presented in Section 6.2.

\subsection{EXPOSURE ASSESSMENT UNCERTAINTIES}

Several potential sources of error may arise in all phases of an exposure assessment. Some significant sources of uncertainty are listed below.

- Uncertainties resulting from the lack of thorough environmental sampling data. This uncertainty could lead to an underestimate or overestimate in the exposure analysis.

- Uncertainties associated with using filtered ground water samples. The results of the exposure assessment presented in this document are primarily based on filtered $(0.45-$ micrometer $[\mu \mathrm{m}])$ ground water samples. Therefore, the potential loss of certain ground water constituents as a consequence of filtration is associated with an additional source of uncertainty.

- Uncertainties arising from the assumption that the ground water contaminant source term at the site has reached a steady state and that contaminant concentrations at the exposure point will remain constant for chronic periods of exposure (generally greater than 7 years).

- Uncertainties associated with the additivity of exposure from other pathways. Although the drinking water pathway is considered the major determinant of exposure in this risk assessment, the incremental contribution from the ground water-irrigated produce-ingestion and/or meatingestion pathways (which could not be estimated here) could be significant. 
MILL TAILINGS AREA, INFANTS

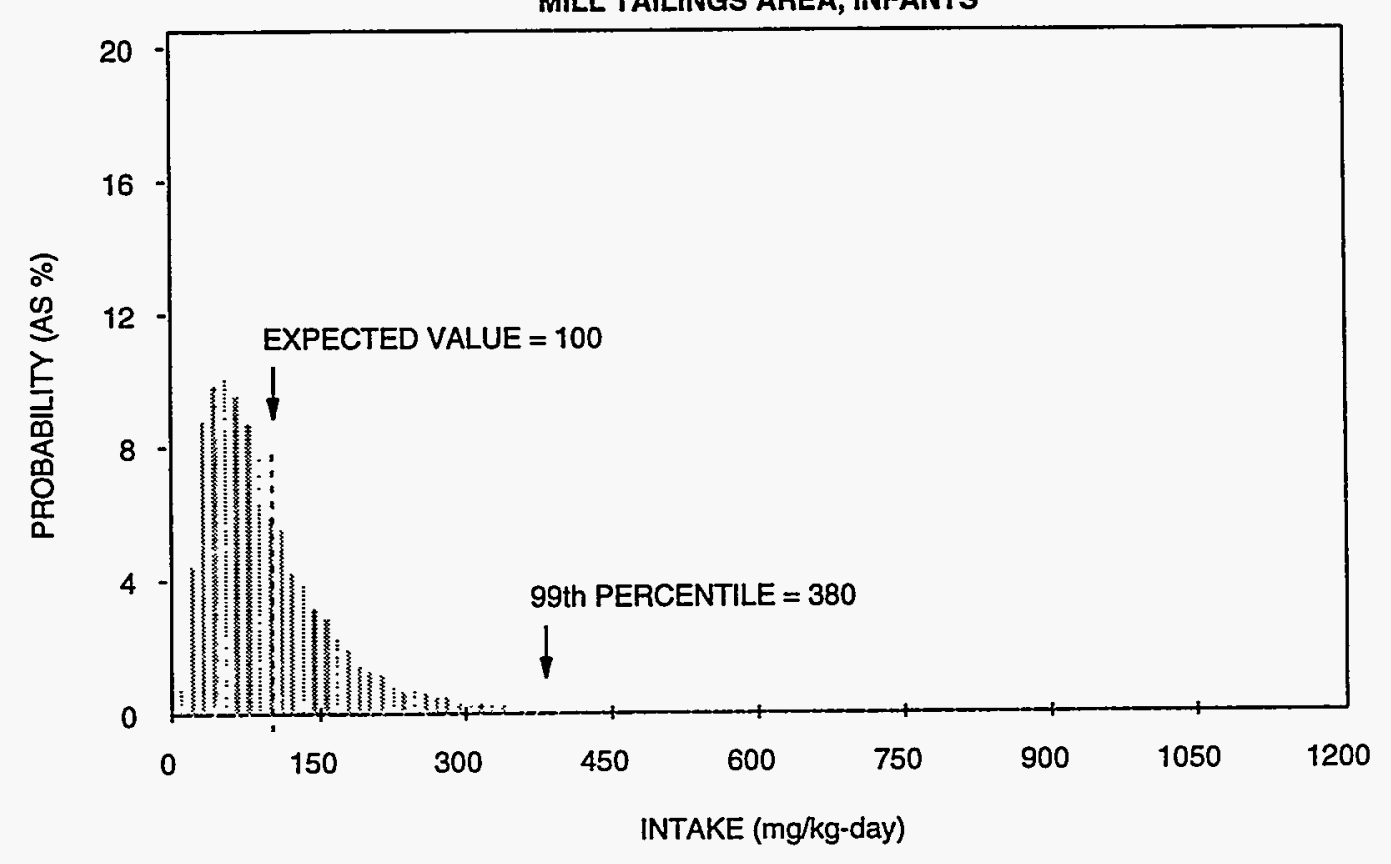

MILL TAILINGS AREA, CHILDREN

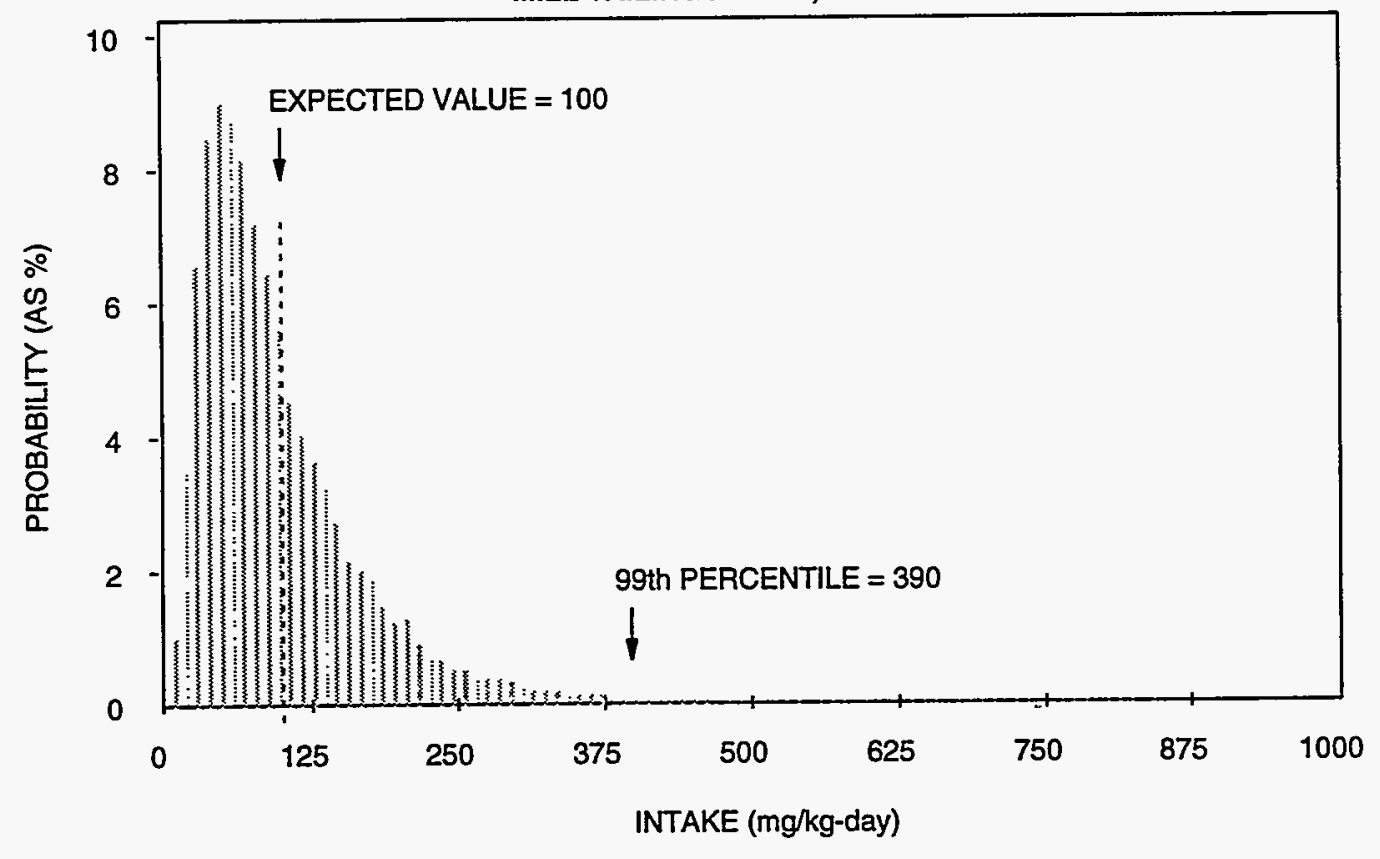

FIGURE 4.13

PROBABILITY DISTRIBUTION OF SULFATE INTAKES DURANGO, COLORADO, SITE 
MILL TAILINGS AREA, ADULTS
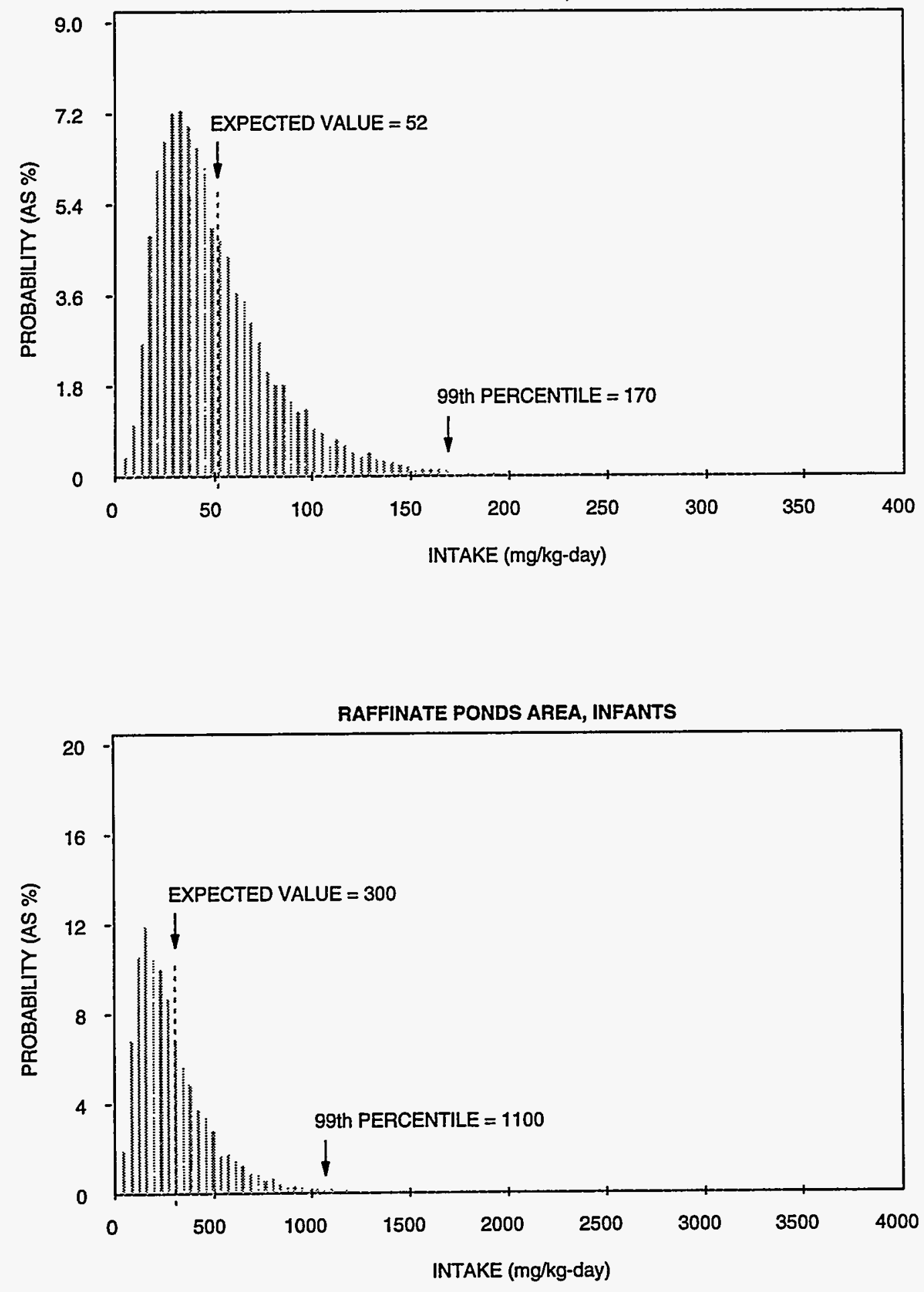

FIGURE 4.13

PROBABILITY DISTRIBUTION OF SULFATE INTAKES DURANGO, COLORADO, SITE (CONCLUDED) 


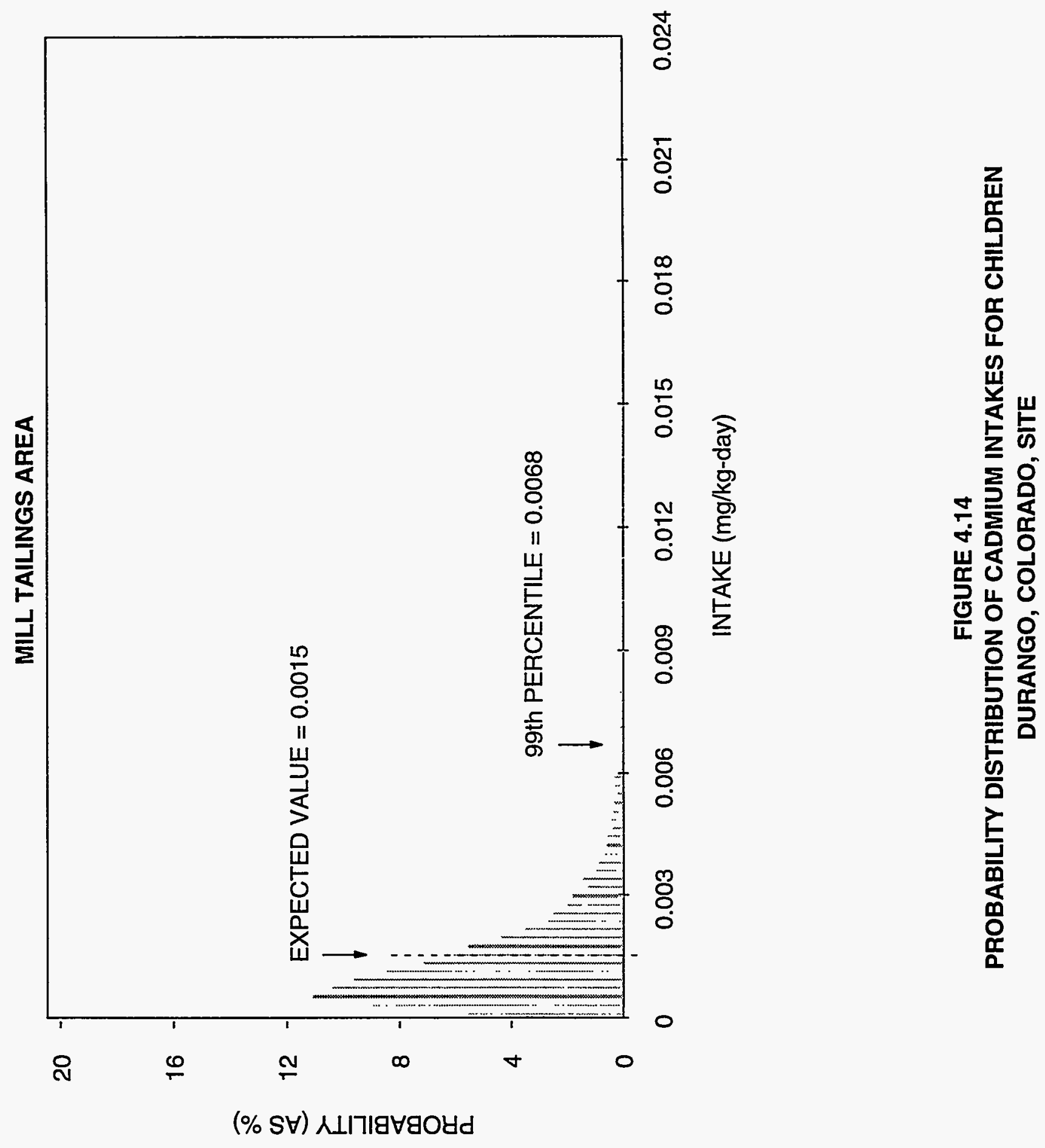




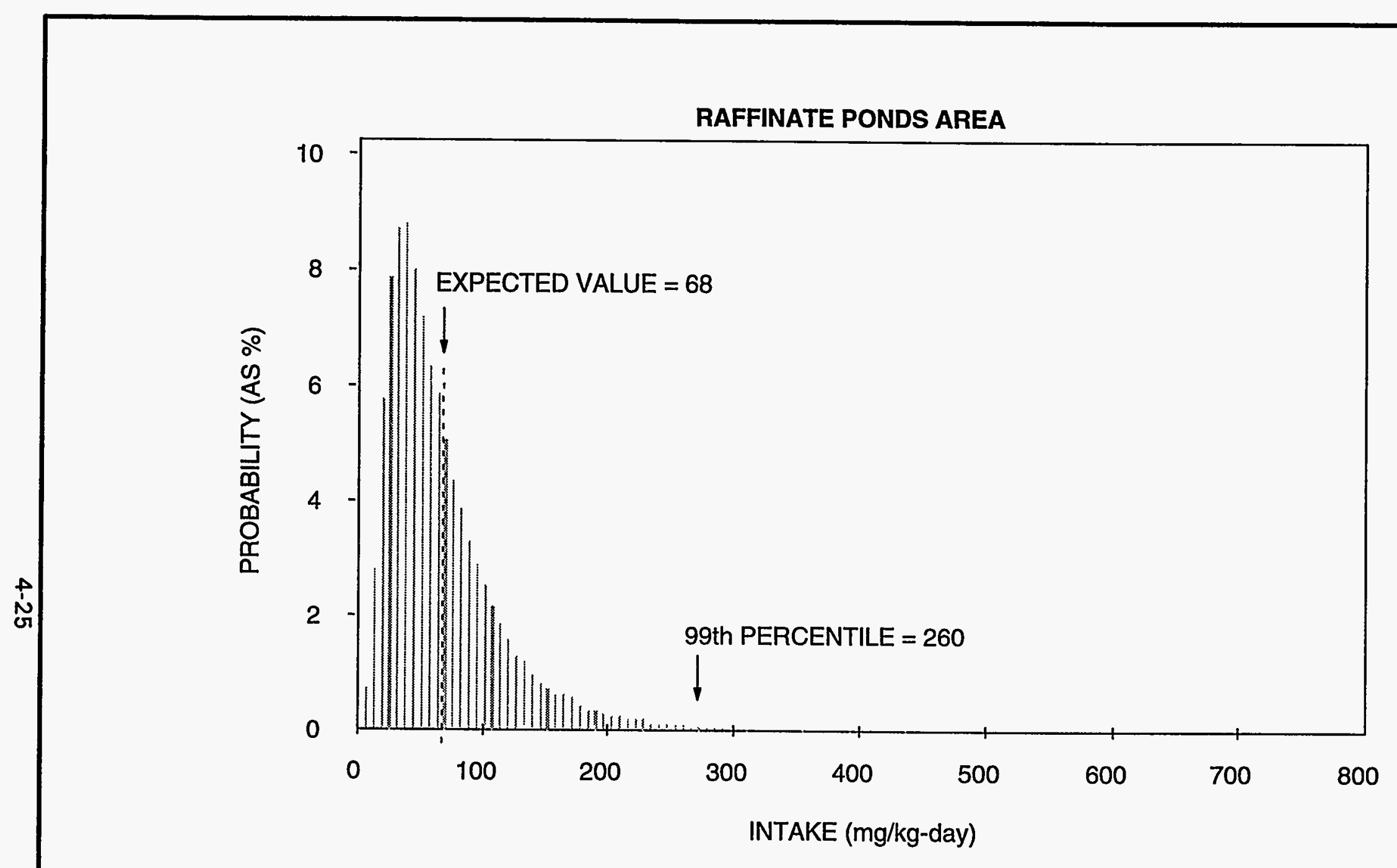

FIGURE 4.15

PROBABILITY DISTRIBUTION OF CHLORIDE INTAKES FOR CHILDREN

DURANGO, COLORADO, SITE 
MILL TAILINGS AREA

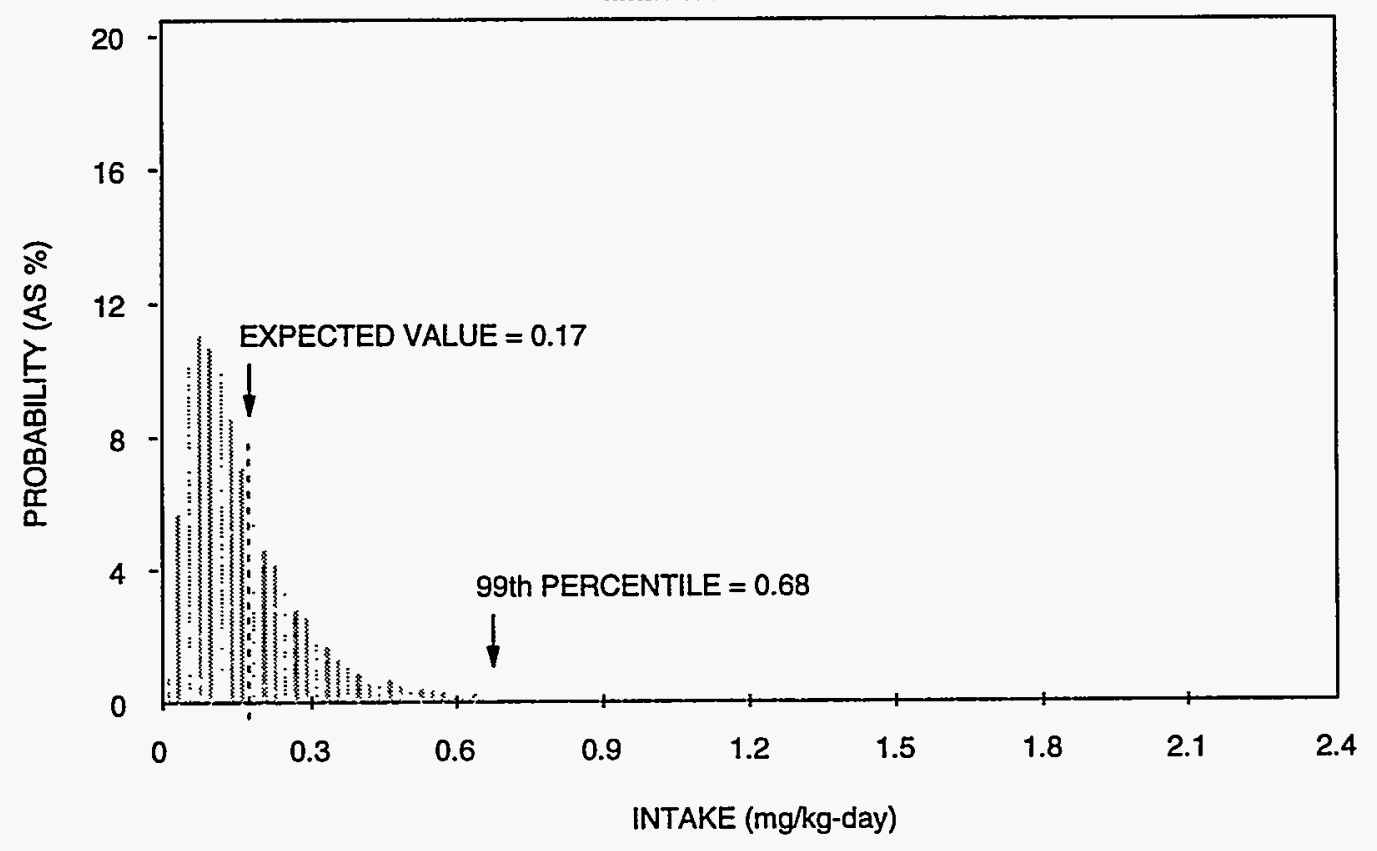

RAFFINATE PONDS AREA

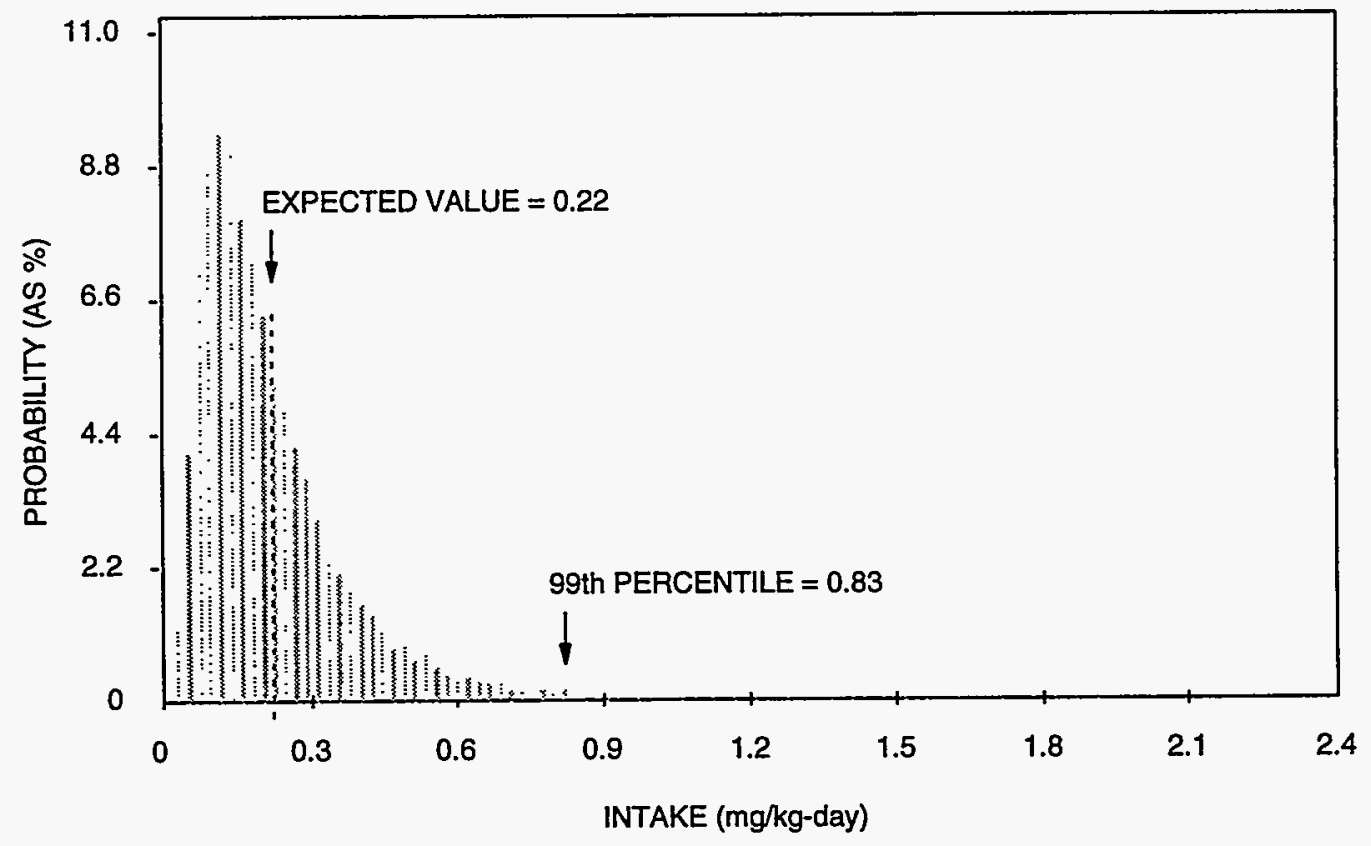

FIGURE 4.16

PROBABILITY DISTRIBUTION OF MANGANESE INTAKES FOR CHILDREN DURANGO, COLORADO, SITE 

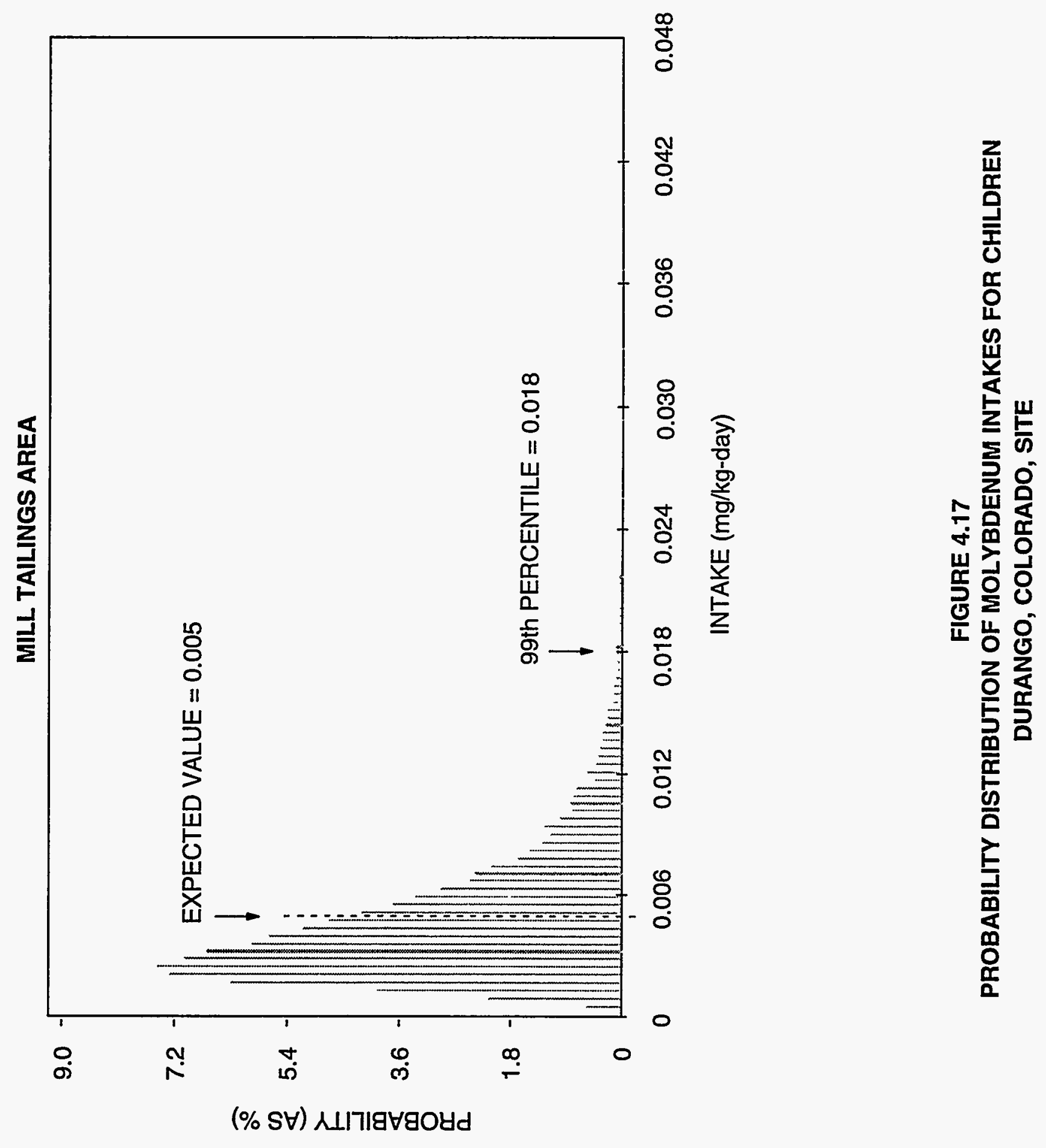

4-27 

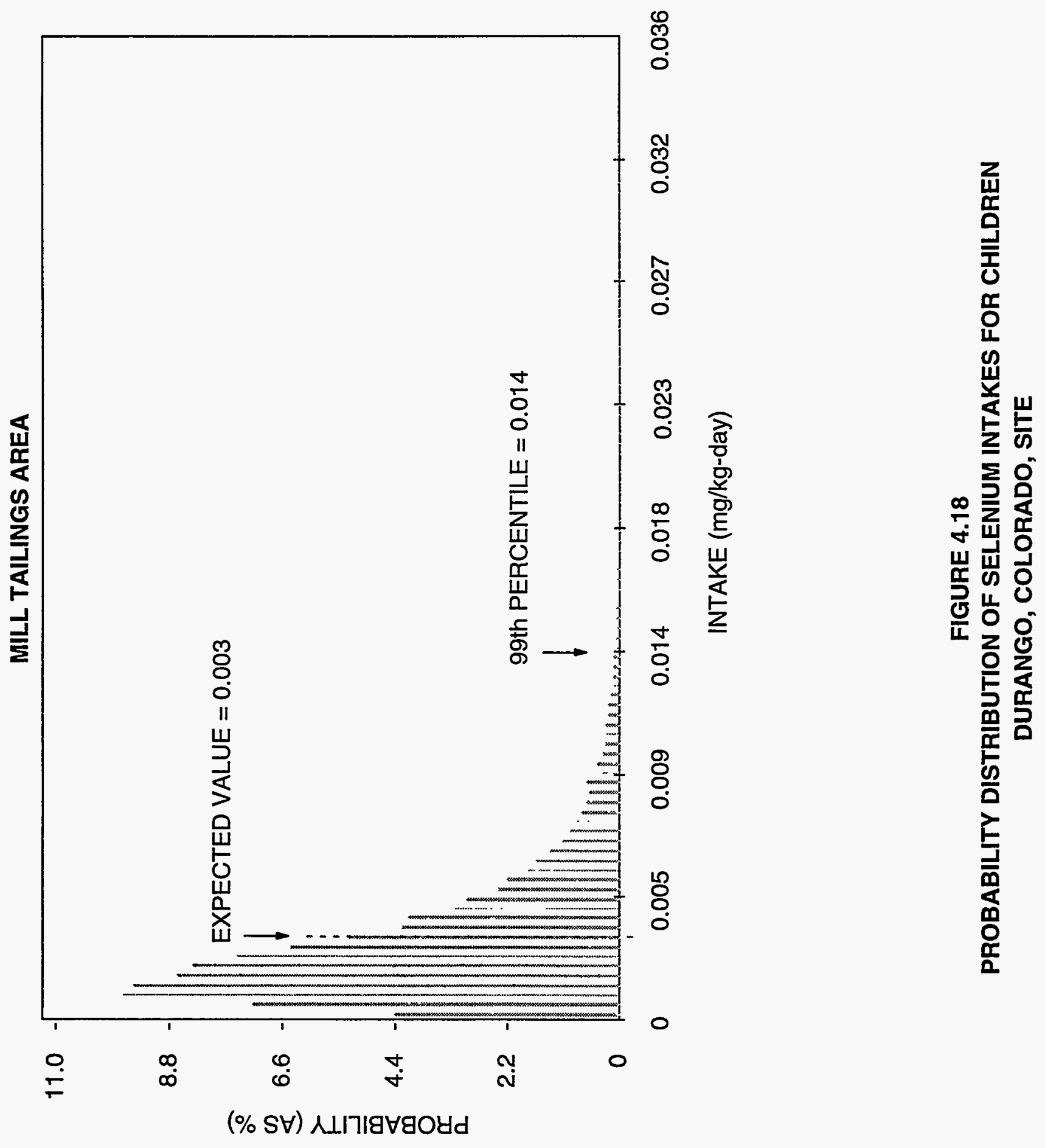
MILL TAILINGS AREA

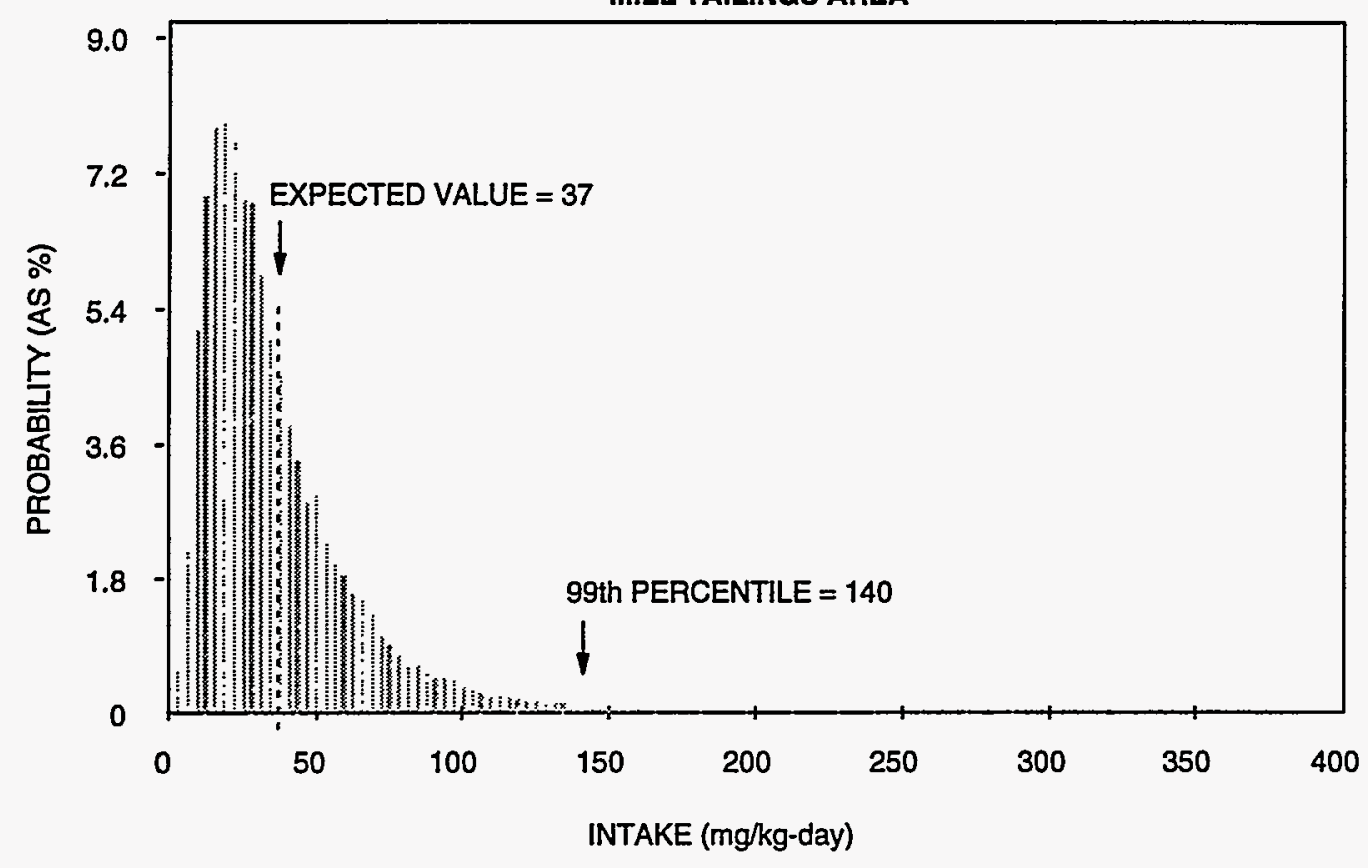

RAFFINATE PONDS AREA

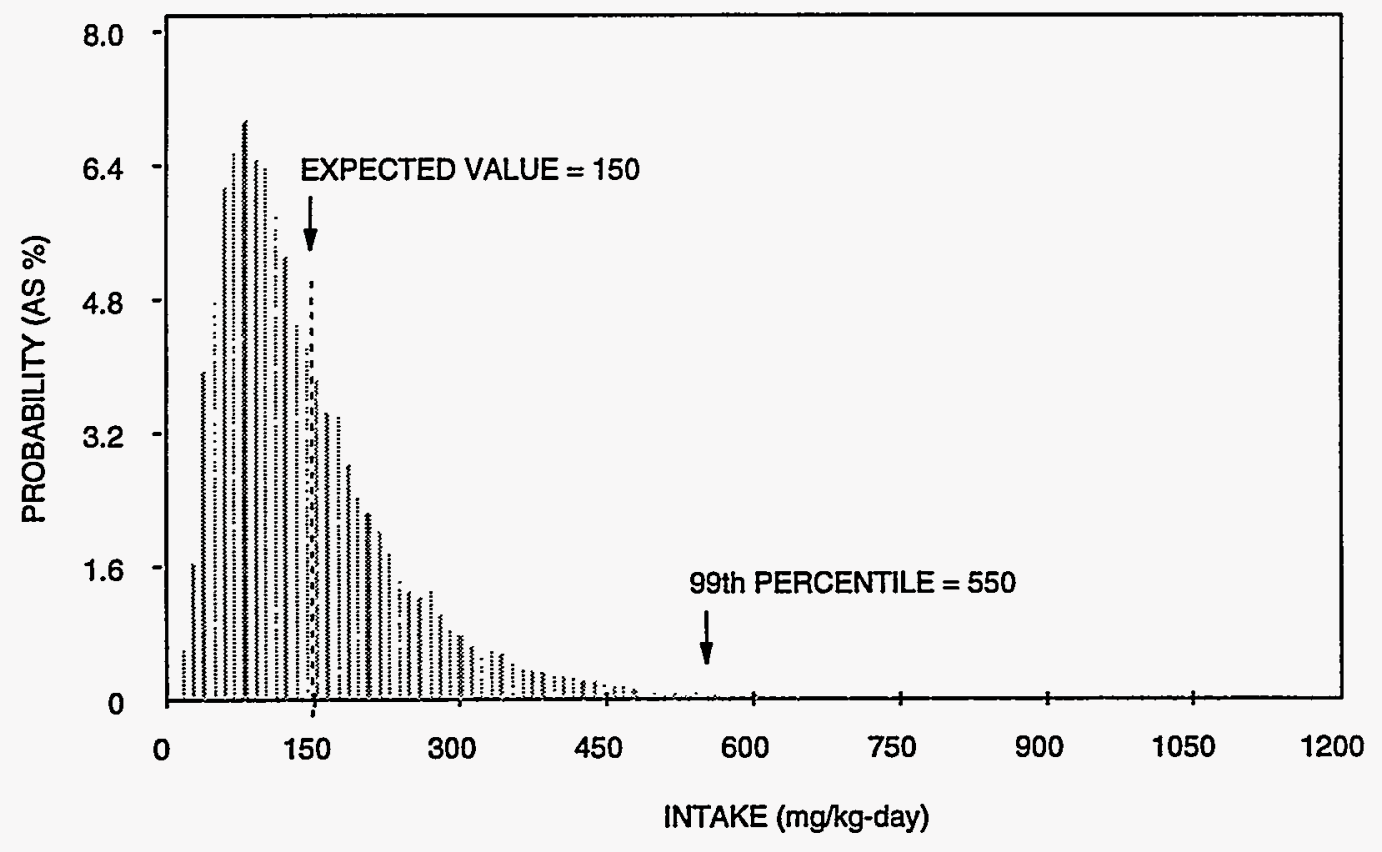

FIGURE 4.19

PROBABILITY DISTRIBUTION OF SODIUM INTAKES FOR CHILDREN DURANGO, COLORADO, SITE 

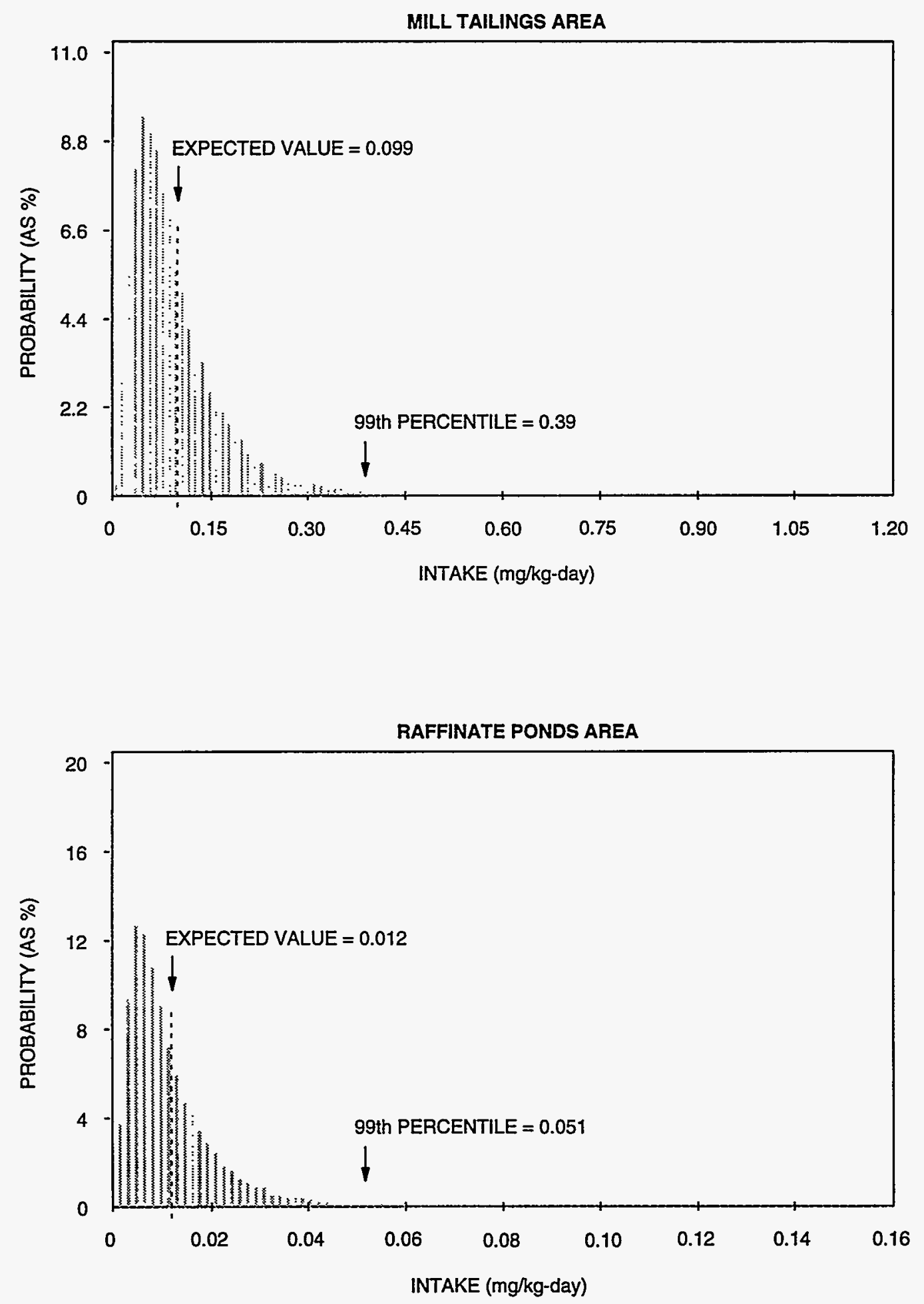

FIGURE 4.20

PROBABILITY DISTRIBUTION OF URANIUM INTAKES FOR CHILDREN DURANGO, COLORADO, SITE 
MILL TAILINGS AREA

FIGURE 4.21

PROBABILITY DISTRIBUTION OF VANADIUM INTAKES FOR CHILDREN

DURANGO, COLORADO, SITE 
- Uncertainties associated with estimating the amount of a contaminant absorbed through the skin.

- Uncertainties associated with differing sensitivities of subpopulations, such as diabetics, children, and the elderly.

- Uncertainties associated with site-specific dietary intakes (e.g., fish ingestion).

Despite these uncertainties, the use of probability distributions that incorporate all definable sources of variability should provide a representative picture of the potential range of exposures. 


\subsection{TOXICITY ASSESSMENT}

A number of contaminants that have the potential for causing adverse human health and environmental effects have been detected in ground water at the mill tailings and raffinate ponds areas at the Durango processing site. This section summarizes the toxicological effects of the chemical contaminants and the carcinogenic potentials of the radionuclides.

The following source materials were used to develop toxicological profiles on these chemical contaminants and the potentially carcinogenic radionuclides:

- The Integrated Risk Information System (IRIS) (EPA, 1994a).

- The Agency for Toxic Substances and Disease Registry Toxicological Profiles, published by the Department of Health and Human Services (DHHS).

- The Handbook on the Toxicology of Metals (Friberg et al., 1986).

- Peer-reviewed scientific literature when these review documents were not available.

Basing toxicity information on the standardized review documents cited above ensures consistency in risk evaluation at all UMTRA Project processing sites.

The toxicity profiles presented here focus on drinking water data in humans. Animal information is used only when human data are not available. Animal data are represented on the toxicity range graphs by widely spaced, dotted lines. Uncertainty about the beginning and ending point of an exposure range that produces specific toxic effects is represented by closely spaced dots.

\section{$5.1 \quad$ CONTAMINANT TOXICITY SUMMARIES}

The following summaries address the basic toxicokinetics and toxicity of the chemical contaminants of potential concern at the Durango processing site. These contaminants are antimony, arsenic, cadmium, chloride, lead, manganese, molybdenum, selenium, sodium, sulfate, thallium, uranium, and vanadium. Although the toxic effects of these contaminants vary with exposure levels, toxic effects observed in the exposure range most relevant to contamination at this site are discussed in this document.

\subsubsection{Antimony}

\section{Absorption}

Antimony can be absorbed both through inhalation and ingestion. At least 15 percent of a single oral dose of labeled antimony potassium tartrate given to mice is absorbed (i.e., recovered in urine and tissues). However, absorption may be higher because gastrointestinal excretion starts immediately after the metal is taken up from the gut (Friberg et al., 1986). 


\section{Tissue accumulation and clearance}

Surface body scanning of people given intravenous injections of labeled antimony as sodium antimony dimercaptosuccinate revealed that the highest amounts accumulate in the liver, thyroid, and heart. Forty-three days after the last injection, the liver still showed values of about one-sixth of the maximum, which was reached 1 day after the last injection (DHHS, 1992a).

Single intravenous or intramuscular injections to human volunteers produced higher 24-hour urinary excretion of pentavalent ( 80 percent) than of trivalent (25 percent) antimony compounds, a pattern similar to the one found in animals (Friberg et al., 1986).

A study on the elimination of a single intravenously administered dose of labeled antimony potassium tartrate (trivalent) indicated that urinary excretion is about four times higher than fecal excretion (DHHS, 1992a). The initial excretion of antimony in humans is rapid. When pentavalent antimony compounds are given intravenously or intramuscularly, more than 90 percent of the dose will be found in the urine within 24 hours (DHHS, 1992a).

\section{Environmental sources of antimony}

Dietary antimony intake ranged from 0.25 to $1.25 \mathrm{mg} / \mathrm{day}$ in a study of institutional diets for children in the United States (Friberg et al., 1986). Assuming an average body weight of $35 \mathrm{~kg}$, this intake is equivalent to 0.007 to $0.04 \mathrm{mg} / \mathrm{kg}$-day.

In freshwater fish, antimony concentrations on the order of 3 micrograms per kilogram $(\mu \mathrm{gg} / \mathrm{kg})$ wet weight have been reported. Levels of 3 and $8 \mu \mathrm{g} / \mathrm{kg}$ have been found in milk and potato powder. Antimony is sometimes present in the binding coat between enamel and metal, especially in older cooking utensils, and can be dissolved by acidic food and drink when the enamel coating is worn. In soil, antimony usually ranges from 0.1 to $10 \mathrm{mg} / \mathrm{kg}$ dry weight (DW).

\section{Toxicity of antimony}

The EPA oral reference dose (RfD) for antimony is $0.0004 \mathrm{mg} / \mathrm{kg}$-day. The RfD is based on a lifetime study of rats exposed to antimony trioxide in drinking water. The lowest dose producing adverse health effects (increased mortality of animals and alteration of blood chemistry) was $0.42 \mathrm{mg} / \mathrm{kg}$-day (EPA, 1994a).

After drinking lemonade containing 0.013 percent antimony, 70 people developed acute symptoms, including burning stomach pain, colic, nausea, and vomiting. It is estimated that a $70-\mathrm{kg}$ adult consuming 300 milliliters $(\mathrm{mL})$ of lemonade would have received a dose of approximately $0.5 \mathrm{mg} / \mathrm{kg}$ (DHHS, 1992a). 
One study indicated that female workers exposed in an antimony plant experienced a greater incidence of spontaneous abortions than did a control group of nonexposed working women. A high rate of premature deliveries among women who worked in antimony smelting and processing was also observed (Friberg et al., 1986). Reconstruction of dose and exposure conditions in the occupational setting is not available. The health effects from exposure to antimony as a function of dose are summarized in Figure 5.1.

\subsubsection{Arsenic}

\section{Absorption}

Arsenic is effectively absorbed through the gastrointestinal tract and via inhalation. Relative to gastrointestinal absorption, dermal absorption is negligible. In humans, approximately 80 percent of an ingested amount of dissolved inorganic trivalent (arsenite) or pentavalent arsenic (arsenate) is absorbed from the gastrointestinal tract (Pershagen and Vahter, 1979; Marafante and Vahter, 1987).

\section{Tissue accumulation and clearance}

After absorption by the gastrointestinal tract, arsenic is transported via the blood to most tissues. In humans as well as in most animal species, exposure to either arsenite or arsenate leads to an initial accumulation in the liver, kidneys, and lungs. The clearance from these tissues is very rapid, and a long-term retention of arsenic is seen in organs rich in sulfhydryl-containing proteins, such as the hair, skin, squamous epithelium of the upper gastrointestinal tract, epididymis, thyroid, lens, and skeleton (Lindgren et al., 1982). Specific target tissue depends on the form of arsenic. Higher retention of arsenic occurs after exposure to trivalent arsenic than to the pentavalent form, and tissue distribution is altered (Webb, 1966; Casarett and Doull, 1991).

In humans and rats, inorganic arsenic passes through the placental barrier. It has also been demonstrated to enter both cow and human milk (Marcus and Rispin, 1988).

In the human body, where methylcobalamine acts as a major methyl group donor in the biotransformation process, inorganic arsenic is converted to methylated compounds. It has been demonstrated that the major site of arsenic methylation is the liver (Marcus and Rispin, 1988). Trivalent arsenic is the substrate for methylation, and pentavalent arsenic must be reduced to trivalent arsenic before methylation can occur. Dimethylarsenic acid is a major metabolite found in animals and humans. Methylation results in a detoxification of inorganic arsenic (about one order of magnitude per methyl group) and increases the rate of arsenic excretion from the body. 


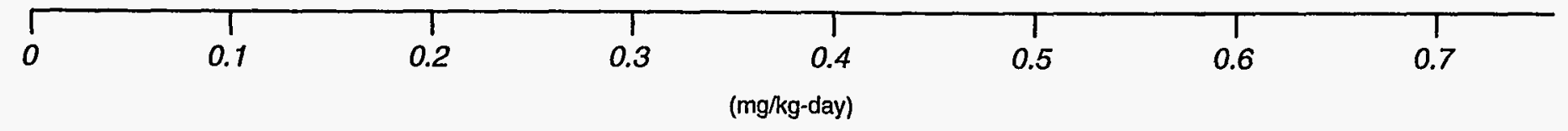

1

DIETARY INTAKE LEVELS

$\triangle$ ORAL RID $(0.0004 \mathrm{mg} / \mathrm{kg}$-day)

MILD TOXICITY IN RATS

(DECREASED LONGEVITY, ALTERED BLOOD CHEMISTRY)

MILD TOXICITY IN HUMANS

(GASTROINTESTINAL DISTRESS AFTER ACUTE EXPOSURE)

FIGURE 5.1

ANTIMONY TOXICITY RANGES 
The major route of excretion following human exposure to inorganic arsenic is via the kidneys (Ishinishi et al., 1986). Only a few percent is excreted in feces. The rate of excretion in urine varies depending on the chemical form of arsenic, the duration of exposure, and the species exposed. In humans exposed to a single low dose of arsenite, about 35 percent was excreted in urine over a period of 48 hours (Buchet et al., 1980; 1981). In the case of continuous human intake over a few days, 60 to 70 percent of the daily dose is excreted in urine (Buchet et al., 1981). Following exposure to arsenate, the limited human data available indicate a rate of excretion similar to that of arsenite. Other, less important routes of elimination of inorganic arsenic include skin, hair, nails, and sweat.

After oral intake of radiolabeled pentavalent arsenic, 66 percent was excreted with a half-time of 2.1 days, 30 percent with a half-time of 9.5 days, and 3.7 percent with a half-time of 38 days (Marcus and Rispin, 1988).

\section{Environmental sources of arsenic}

Arsenic is ubiquitous in nature in both inorganic and organic compounds. Water is the major means of arsenic transport under natural conditions. In oxygenated water, arsenic occurs in a pentavalent form; under reducing conditions, the trivalent form predominates.

As a result of arsenic's widespread occurrence, the general human population is exposed to it primarily from drinking water and foodstuffs. Certain target groups are exposed to arsenic from industrial and agricultural uses. Medicinal use has also been a significant means of human exposure.

Drinking water usually contains a few micrograms of arsenic, predominantly as inorganic salts in the trivalent and pentavalent states (WHO, 1981; DHHS, 1993a). However, concentrations of up to $1.1 \mathrm{mg} / \mathrm{L}$ in drinking water have been reported in Chile, Argentina, Taiwan, the United States, and the United Kingdom (WHO, 1981).

Seafood, meats, and grains contain the highest levels of arsenic. Wine and mineral waters can contain several hundred micrograms of arsenic per liter (Crecelius, 1977; WHO, 1981).

\section{Toxicity of arsenic}

Levels of exposure associated with acute arsenic toxicity vary with the valency form of the element. Trivalent arsenicals (arsenites) are generally more toxic than pentavalent (arsenates) (Morrison et al., 1989), and inorganic arsenic compounds are more toxic than organic (Shannon and Strayer, 1989). Based on geochemical models for the Durango site, arsenic exists primarily in the pentavalent form in ground water (Tables 3.13 and 3.14). For arsenic trioxide, the reported estimated acute oral lethal dose in humans ranges from 70 to $300 \mathrm{mg}$ (1 to $4 \mathrm{mg} / \mathrm{kg}$ ) (EPA, 1984). Acute exposure to inorganic arsenic 
compounds may lead to severe inflammation of the gastrointestinal tract, encephalopathy, and acute renal failure after ingestion.

Increasing chronic doses of arsenic ingested orally progressively produce systemic effects, including 1) arterial thickening in children and adults $(0.02 \mathrm{mg} / \mathrm{kg}$-day); 2) neurological symptoms, including peripheral neuropathy $(0.04 \mathrm{mg} / \mathrm{kg}$-day); 3) fibrosis of the liver $(0.05 \mathrm{mg} / \mathrm{kg}$-day); and 4) cirrhosis of the liver $(0.08 \mathrm{mg} / \mathrm{kg}$-day) (DHHS, 1993a).

Chronic arsenic intoxications result from exposure to even small doses of arsenic over a long period of time. These intoxications are frequently caused by arsenic content in drinking water and in food. Changes of the skin leading to skin cancer are commonly seen in populations exposed to high concentrations of arsenic in drinking water. Endemic arsenic poisoning is seen in Cordoba, Argentina, where the concentration of arsenic in drinking water ranges from 0.9 to $3.4 \mathrm{mg} / \mathrm{L}$ (equivalent to 0.026 to $0.097 \mathrm{mg} / \mathrm{kg}$-day). Certain areas in Taiwan also have high natural arsenic concentrations in drinking water that cause Blackfoot disease (a peripheral extremity vascular disorder resulting in gangrene). A dose-response relationship between the incidence of Blackfoot disease and the duration of exposure to arsenic has been documented (Tseng, 1977; EPA, 1994a). The lowest dose of arsenic associated with Blackfoot disease in continuously exposed individuals has been determined to be $0.014 \mathrm{mg} / \mathrm{kg}$-day (DHHS, 1993a).

Hyperpigmentation, hyperkeratosis, and skin cancer with prevalence of 7.1 percent, 18.4 percent, and 1.1 percent, respectively, were reported in Taiwanese studies of more than 40,000 people exposed to arsenic in drinking water at daily intakes ranging from 1.4 to $6.3 \mathrm{mg}$. However, hyperkeratosis and hyperpigmentation were observed at an exposure level as low as $0.014 \mathrm{mg} / \mathrm{kg}$-day (DHHS, 1993a).

Teratogenic effects of arsenic compounds administered intravenously or intraperitoneally at high doses have been demonstrated in laboratory animals only (Ferm, 1971; Hood, 1972; EPA, 1984). Teratogenic effects, also referred to as birth defects, are defined as effects resulting in structural or functional anomalies in live offspring.

Certain characteristics of exposed human populations may influence arsenic toxicity at high exposure levels. Genetic dispositions (rapid versus poor acetylators) and protein-deficient diet may decrease the methylation of arsenic. This can result in an increased deposition of the element in the target organs (e.g., lung or skin).

The EPA has classified inorganic arsenic as a Group A (human) carcinogen (EPA, 1994a), based on the occurrence of increased lung cancer mortality (in populations exposed primarily via inhalation) and of increased skin cancer prevalence (in populations exposed by consuming drinking water containing high concentrations of arsenic). The current slope factor (SF) for oral exposure to 
arsenic is given in Table 5.1. This SF is currently under review by the EPA with respect to recent data suggesting arsenic ingestion may result in increased cancers in internal organs as well as skin cancers. The health effects from exposure to arsenic as a function of dose are summarized in Figure 5.2.

\subsubsection{Cadmium}

\section{Absorption}

In humans, approximately 5 percent of ingested cadmium in water is absorbed (Friberg et al., 1986). The amount of cadmium absorbed from food sources is about half the amount absorbed from water. Gastrointestinal absorption is likely to depend on the physiologic status of an individual (age, body stores of iron) and on the presence and levels of divalent and trivalent cations and other dietary components ingested with cadmium. Young individuals appear to absorb more cadmium than older ones, and its absorption is increased in individuals with a diet high in fat and protein (Flanagan et al., 1978; DHHS, 1993b). Cadmium gastrointestinal absorption can decrease following exposure to calcium, chromium, magnesium, and zinc. Zinc and iron deficiency may result in an increased absorption and accumulation of cadmium.

Cadmium absorption in the gastrointestinal tract appears to take place in two phases: uptake from lumen into mucosa, then transfer in the blood (DHHS, $1993 \mathrm{~b})$. Cadmium uptake from lumen into mucosa may involve sequestering of cadmium by metallothionein, but any protective effect is overloaded at moderate doses. Cadmium uptake behaves like a saturable process with fractional absorption decreasing at high concentrations. However, at doses high enough to damage gastrointestinal mucosa, fractional cadmium absorption is increased (DHHS, 1993b).

\section{Tissue accumulation and clearance}

Humans with low-level and long-term exposure to cadmium show 50 percent of the body burden in the kidneys, 15 percent in the liver, and 20 percent in muscle (Kjellström, 1979). The kidney concentration will increase with continued exposure only to about age 50 , but the concentration in muscle will increase throughout life. Only 0.01 to 0.02 percent of the total body burden of cadmium is excreted daily, resulting in continuously increasing body burdens with prolonged exposure. The biological half-life of cadmium, or the time necessary to eliminate 50 percent of the cadmium in the body at a given time, is 10 to 30 years in humans (Nordberg et al., 1985).

\section{Environmental sources of cadmium}

The average cadmium content of drinking water in nonpolluted areas of $0.003 \mathrm{mg} / \mathrm{L}$ results in about $0.00009 \mathrm{mg} / \mathrm{kg}$-day intake of cadmium estimated for a $70-\mathrm{kg}$ adult drinking $2 \mathrm{~L}$ of water per day. For a $22-\mathrm{kg}$ child drinking $0.7 \mathrm{~L}$ of water per day, the estimated cadmium intake is $0.0001 \mathrm{mg} / \mathrm{kg}$-day 
Table 5.1 Toxicity values: potential carcinogenic effects

\begin{tabular}{|c|c|c|c|c|}
\hline Parameter & $\begin{array}{c}\text { Oral SFa }(\mathrm{pCi})^{-1} \\
\text { (mg/kg-day) }^{-1}\end{array}$ & $\begin{array}{c}\text { Weight of } \\
\text { evidence } \\
\text { classification }\end{array}$ & Type of cancer & $\begin{array}{l}\text { SF basis/SF } \\
\text { source }^{b}\end{array}$ \\
\hline $\begin{array}{l}\text { Arsenic, } \\
\text { inorganic }\end{array}$ & $1.8 \mathrm{E}+00^{C}$ & A & Skin & Water/IRIS \\
\hline Lead-210e & $6.6 \mathrm{E}-10$ & A & Bone & Water/HEAST \\
\hline Polonium-210 & $1.5 E-10$ & A & Liver, kidney, spleen & Water/HEAST \\
\hline Radium-226 ${ }^{e}$ & $1.2 \mathrm{E}-10$ & A & Bone & Water/HEAST \\
\hline Thorium-230 & $1.3 \mathrm{E}-11$ & A & Bone & Water/HEAST \\
\hline Uranium-238 & $2.0 \mathrm{E}-11$ & $A$ & $f$ & Water/HEAST \\
\hline Uranium-234 & $1.6 \mathrm{E}-11$ & A & $\mathbf{f}$ & Water/HEAST \\
\hline
\end{tabular}

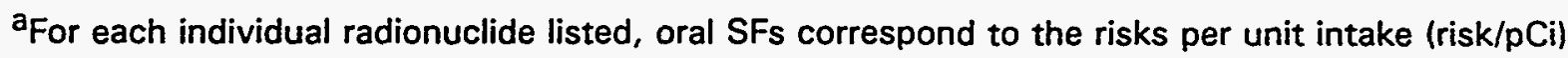
for that radionuclide, except as noted.

${ }^{b}$ From EPA (1994b).

${ }^{C}$ Oral SF based on oral unit risk of $5 \times 10^{-5}$ (EPA, 1994a).

dEPA, 1994a.

e Oral SFs include the risk from members of the decay chain.

fo human or animal studies have shown a definite association between oral exposure to uranium and development of cancer.

A - Human carcinogen. 


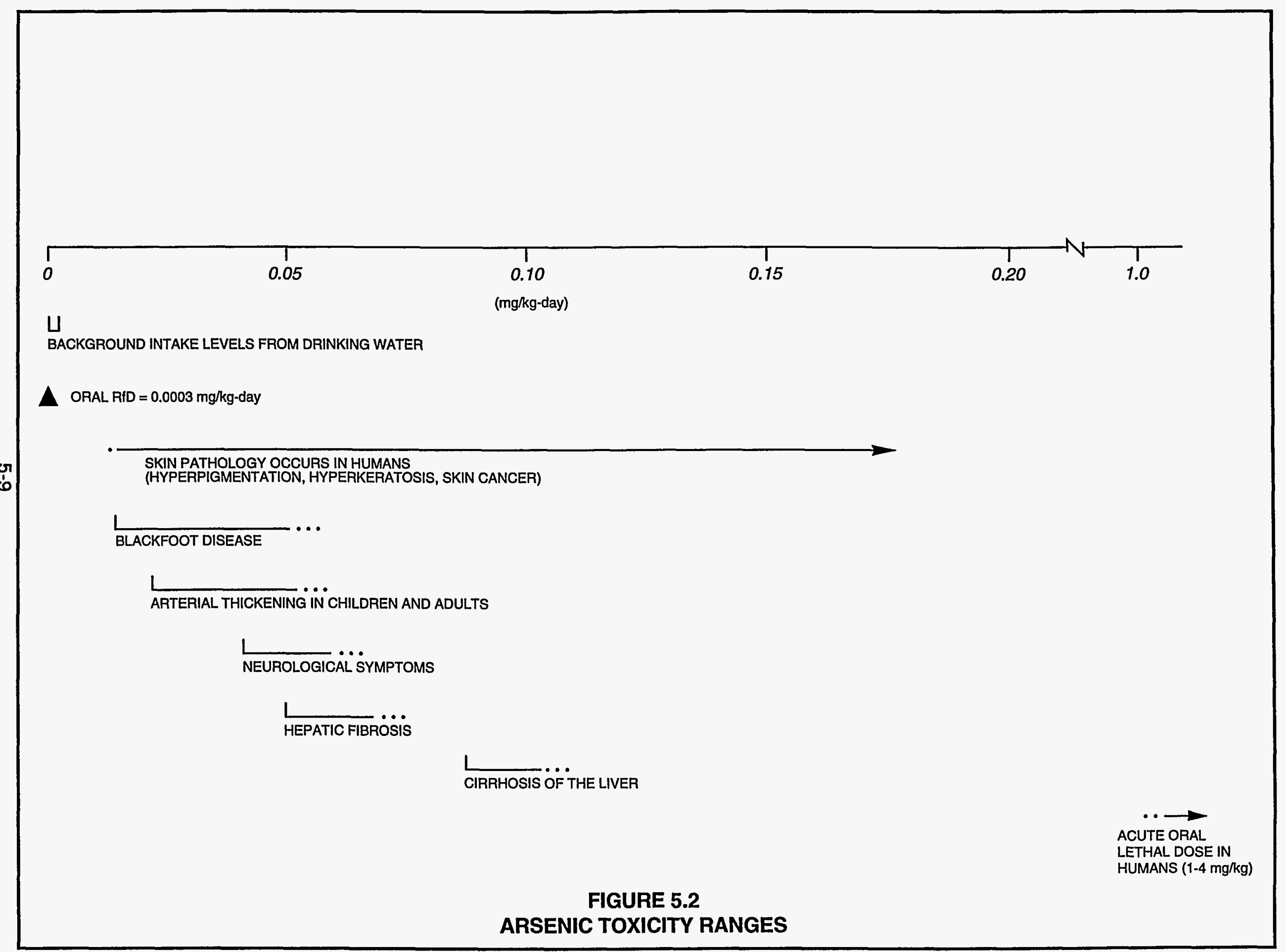

MAC: SITEJDUR/BLRAAARS-GEN 
(DHHS, 1993b). Cadmium occurs naturally with zinc and lead; it is therefore often present as an impurity in products using these metals, such as solders and galvanized metals. These sources lead to contact with water supplies in water heaters and coolers, in some pipes, and in taps.

\section{Toxicity of cadmium}

Short-term exposure to high concentrations of cadmium (15 mg/L in water) results in acute gastrointestinal effects, including abdominal cramps, diarrhea, and vomiting $10.48 \mathrm{mg} / \mathrm{kg}$ for a $22-\mathrm{kg}$ child drinking $0.7 \mathrm{~L}$ of water per day). These gastrointestinal effects have not been reported in any chronic environmental exposure.

In chronic oral human exposure, the kidney is the main target organ of cadmium toxicity (DHHS, 1993b). The primary toxic effect is disturbance of reabsorption in the proximal tubules of the kidney. This effect is first observed by an increase of low molecular-weight proteins in the urine. This initial effect is observed following a daily intake of $0.0075 \mathrm{mg} / \mathrm{kg}$-day. Progressive disruption of kidney function will lead to an increase in amino acids, glucose, phosphate, and protein in the urine. The critical concentration of cadmium in the renal cortex below which no adverse effect would be anticipated has been estimated at about $200 \mu \mathrm{g} / \mathrm{gram}$ fresh weight (Foulkes, 1990; EPA, 1994a). However, the apparent critical level of cadmium in the kidney can vary significantly under different conditions of exposure; it can be affected by age, sex, and other factors influencing individual sensitivity to cadmium toxicity. The EPA-derived RfD is based on the critical concentration of cadmium in the human renal cortex that is not associated with the critical effect manifested as significant proteinuria (EPA, 1994a). Because of already compromised kidney function, diabetics and the elderly can be more susceptible to cadmium toxicity (Buchet et al., 1990). Long-term exposures can also disturb calcium metabolism, leading to osteoporosis and osteomalacia. A combination of these two effects is referred to as Itai-itai disease and was seen in epidemic proportions in a cadmium-contaminated region in Japan in the 1950s (Friberg et al., 1986). Chronic dietary exposures of humans to cadmium produce no observable adverse effects at exposure levels from 0.001 to $0.002 \mathrm{mg} / \mathrm{kg}$-day (DHHS, $1993 \mathrm{~b})$. The health effects from exposure to cadmium as a function of dose are summarized in Figure 5.3.

Cadmium has been classified as a probable human carcinogen by the EPA (EPA, 1994a) and International Agency for Research on Cancer (IARC) (IARC, 1987). Although chronic inhalation of cadmium oxide has been related to increased lung and prostate cancers in workers, evidence linking cadmium to cancer in humans is inconclusive at this time because of the presence of other known carcinogens in the workplace and small statistical differences in tumor incidences (DHHS, 1993b). There are no data, however, linking oral cadmium ingestion to cancer in humans or animals (DHHS, 1993b). 


\begin{tabular}{lll|l|l|l|l|l|l|l}
\hline & 0.001 & 0.002 & 0.003 & $\substack{0.004 \\
\text { (mg/kg-day) }}$ & 0.005 & 0.006 & 0.007 & 0.008 & 0.5
\end{tabular}

I AVERAGE BACKGROUND INTAKE LEVEL FROM DRINKING WATER

$\triangle$ ORAL RID - DRINKING WATER (0.0005 mg/kg-day)

...........

NO OBSERVED EFFECTS FROM DRINKING WATER CONSUMPTION

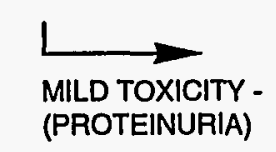

$\cdots \longrightarrow$

ACUTE TOXICITY $(0.48 \mathrm{mg} / \mathrm{kg}$ DOSE ESTIMATED FOR A

CHILD)

FIGURE 5.3

CADMIUM TOXICITY RANGES 


\subsubsection{Chloride}

\section{Absorption, tissue accumulation, and clearance}

Chloride is rapidly and fully absorbed from the gastrointestinal tract. The chloride concentration in the human body is approximately $2000 \mathrm{mg} / \mathrm{kg}$ of fat-free body mass in newborns and $1920 \mathrm{mg} / \mathrm{kg}$ in adults (National Research Council, 1980). Chloride occurs in plasma at concentrations of 96 to 106 milliequivalents per liter $(\mathrm{mEq} / \mathrm{L})(3400$ to $3800 \mathrm{mg} / \mathrm{L})$ and in a more concentrated form in cerebrospinal fluid and gastrointestinal secretions (National Research Council, 1989). Its concentration in most cells is low. The daily chloride turnover in adults (intake/output) ranges from 3000 to $8900 \mathrm{mg}$. Chloride is excreted mainly through urine, with appreciable amounts also excreted in feces, sweat, and tears.

\section{Environmental sources of chloride}

Dietary chloride comes almost entirely from sodium chloride (National Research Council, 1989). Much smaller amounts are supplied from potassium chloride. Thus, dietary sources of chloride essentially are the same as those for sodium, and processed foods are the major source of chloride. Rich sources of chloride are salt, cereals, breads, dried skim milk, teas, eggs, margarine, salted butter, bacon, ham, corned beef, canned meats, fish and vegetables, salted snack foods, and olives. Dietary chloride intake varies largely with salt intake. Estimates range from 2400 to $14,400 \mathrm{mg}$ chloride/day from sodium chloride (equivalent to 34 to $206 \mathrm{mg} / \mathrm{kg}$-day for a $70-\mathrm{kg}$ man).

Human breast milk contains $11 \mathrm{mEq} / \mathrm{L}$ of chloride (391 mg/L); a similar level has been suggested by the American Academy of Pediatrics for infant formulas (National Research Council, 1989).

Chloride is found in all natural water. Surface water contains only a few milligrams of chloride per liter, whereas streams in arid or semiarid regions contain several hundred milligrams per liter, especially in drained areas where chlorides occur in natural deposits or are concentrated from soils through evaporation. Contamination with sewage increases the chloride content of river water. Ground water usually contains larger quantities of chloride than surface water. Some public supply wells may contain $100 \mathrm{mg} / \mathrm{L}$ of chloride (about $3 \mathrm{mg} / \mathrm{kg}$-day, assuming $2 \mathrm{~L}$ of water are consumed per $70 \mathrm{~kg}$ of body weight) (National Research Council, 1980).

A typical chloride concentration in drinking water of about $21 \mathrm{mg} / \mathrm{L}$ would contribute $0.6 \mathrm{mg} / \mathrm{kg}$-day lassuming $2 \mathrm{~L}$ per day consumption rate and $70 \mathrm{~kg}$ of body weight), or about 2 percent of the lower estimates of total chloride intake.

The recommended drinking water level for chloride is $250 \mathrm{mg} / \mathrm{L}$ (equivalent to $7 \mathrm{mg} / \mathrm{kg}$-day, for a $70-\mathrm{kg}$ man consuming $2 \mathrm{~L}$ of water per day) (National Research Council, 1980). This amount of chloride in drinking water can cause 
an objectionably salty taste in water. The taste threshold for the chloride anion in water varies from 210 to $310 \mathrm{mg} / \mathrm{L}$.

\section{Toxicity of chloride}

Chloride is an important inorganic anion in the extracellular fluid compartment. It is essential in maintaining fluid and electrolyte balance and is a necessary component of gastric juice.

Chloride loss from the body generally parallels sodium loss. Thus, conditions associated with sodium depletion (e.g., heavy, persistent sweating; chronic diarrhea or vomiting; trauma; renal disease) will also cause chloride loss, resulting in hypochloremic metabolic alkalosis.

Although the basic need for chloride is generally recognized, a recommended daily allowance (RDA) has not been determined. The estimated minimum requirement for healthy persons ranges from $180 \mathrm{mg} / \mathrm{day}$ for infants to $750 \mathrm{mg} /$ day for adults (National Research Council, 1989).

The toxicity of salts containing the chloride ion depends primarily on the characteristic of the cation (National Research Council, 1980; 1989).

Large amounts of chloride intake may cause an increased chloride plasma concentration and a decreased bicarbonate plasma concentration, with an acidifying effect. This reaction results in hyperkalemic metabolic acidosis (National Research Council, 1980). When metabolic acidosis develops, potassium leaves the cells and is excreted by the kidney (Brater, 1992).

The only known dietary hyperchloremia results from water-deficiency dehydration. Sustained ingestion of high levels of chloride (as salt) is associated with hypertension in sensitive individuals and in animal models. Although the level of chloride attributable to hypertension has not been determined, it may be estimated based on the level of sodium intake (from sodium chloride) causing hypertension in approximately 15 percent of adults (Freis, 1976). This indirectly estimated amount of chloride presumably associated with hypertension in sensitive individuals would be in the range of 36 to $180 \mathrm{mg} / \mathrm{kg}$-day.

Figure 5.4 shows the toxicity of chloride as a function of dose.

\subsubsection{Lead}

\section{Absorption}

About 10 percent of ingested lead is absorbed in the gastrointestinal tract, although in some adults up to 40 percent may be absorbed. Higher fractions of lead may be absorbed by infants, children, fasting adults, and people with certain nutritional deficiencies. Up to 53 percent absorption was reported in a group of eight children ranging in age from 3 months to 8 years (WHO, 1977). 


\begin{tabular}{|c|c|c|c|c|c|c|c|}
\hline & $T$ & $T$ & 1 & $T$ & $\Gamma$ & 1 & 1 \\
\hline 0 & 50 & 100 & 150 & 200 & 250 & 300 & 350 \\
\hline
\end{tabular}

$\Downarrow$

INTAKE FROM DRINKING WATER

A RECOMMENDED INTAKE LIMIT FROM WATER

DIETARY INTAKE LEVELS

$\ldots \ldots \ldots \ldots \ldots \ldots \ldots \ldots$

HYPERTENSION IN HUMANS (DOSE RECONSTRUCTION;

BASED ON SODIUM CHLORIDE INTAKE ASSOCIATED WITH

HYPERTENSION IN HUMANS) 
Animal studies show that certain dietary factors (e.g., milk consumption; fasting; low potassium, calcium, and vitamin D; and iron deficiency) may enhance lead absorption. A low-protein diet may increase susceptibility to lead toxicity (DHHS, 1993c). Phosphate may decrease absorption of lead (Heard and Chamberlain, 1982).

The chemical form of lead affects the readiness with which lead is absorbed from the gastrointestinal tract. Highly soluble compounds are more readily absorbed.

\section{Tissue accumulation and clearance}

Absorbed lead is transported by the blood and initially distributed to various organs and tissues. It is then gradually redistributed to blood and soft tissue from the bone. In human subjects with low-level exposure, about 90 percent of the total body burden is found in bone (DHHS, 1993c). Lead in a skeleton has a half-life of about 20 years, and the amount of lead in this compartment increases throughout life. The second, smaller compartment (blood, soft tissue, and rapidly exchangeable bone fraction) has a half-life of about 20 days. Some studies indicate that the mean retention of lead in blood and soft tissue is about 3 weeks to 1 month and in bone about 5 years (DHHS, 1993c). Lead accumulates in the brain and can be retained for a long time after the external exposure has ceased and the concentration of lead in the blood has declined.

About 90 percent of ingested lead is eliminated unabsorbed in feces. Absorbed lead is excreted mainly in urine (about 76 percent) and through gastrointestinal secretion (about 16 percent); small amounts (less than 8 percent) are excreted in milk, sweat, hair, and nails (DHHS, 1993c). Glomerular filtration is the primary mechanism of lead urinary excretion.

Lead levels in blood are the most widely used biological indicator of internal lead exposure. A blood lead level greater than $10 \mu \mathrm{g} / 100 \mathrm{~mL}$ indicates an excessive lead exposure (DHHS, 1993c).

Lead readily crosses the placental barrier; therefore, exposure of women to lead during pregnancy results in uptake by the fetus.

\section{Environmental sources of lead}

The chemistry of lead in water is highly complex because it can be found in many forms. It tends to form compounds of low solubility with the major anions of natural water. In the natural environment, the divalent form $\left(\mathrm{Pb}^{+2}\right)$ is the stable ionic species of lead. Natural compounds of lead are usually not mobile in ground water or surface water, because lead tends to combine with carbonate or sulfate ions to form insoluble compounds under oxidizing conditions and extremely insoluble lead sulfide under reducing conditions (DHHS, 1993c). Lead is more mobile in acidic waters, and precipitation occurs more rapidly in alkaline waters. 
Lead has been monitored in surface water, sediments and soils, ground water, and drinking water throughout the world. The lead concentration of surface water varies greatly depending upon pollution sources, sediment lead content, and system characteristics (e.g., $\mathrm{pH}$, temperature). Lead levels in surface waters throughout the United States typically range from 5 to $30 \mu \mathrm{g} / \mathrm{L}$, although levels as high as $890 \mu \mathrm{g} / \mathrm{L}$ have been found (DHHS, 1993c). Sediments contain considerably higher levels of lead than corresponding surface water. The average lead content of river sediments is about $20 \mathrm{mg} / \mathrm{kg}$. The natural concentration of lead in soils ranges from 2 to $200 \mathrm{mg} / \mathrm{kg}$, with mean values about $16 \mathrm{mg} / \mathrm{kg}$, depending upon location (NAS, 1972). The typical lead concentration in ground water ranges from 1 to $100 \mu \mathrm{g} / \mathrm{L}$. In rainwater at 32 U.S. stations, the mean concentration of lead was $34 \mu \mathrm{g} / \mathrm{L}$ and the maximum value observed was $300 \mu \mathrm{g} / \mathrm{L}$. In areas with heavy traffic, lead in rain may exceed $100 \mu \mathrm{g} / \mathrm{L}$ and even reach $500 \mu \mathrm{g} / \mathrm{L}$. In 1990, lead intake from U.S. drinking water was calculated at $12 \mu \mathrm{g} /$ day for a 6 -year old child (equivalent to $0.0012 \mathrm{mg} / \mathrm{kg}$-day) (DHHS, 1993c).

The primary source of lead for the general population is food; for occupational groups, it is inhalation. Important sources of exposure for children in some countries are lead paint, soil, and dust.

The estimated daily dietary intake of lead ranges from 5 to $11 \mu \mathrm{g} / \mathrm{day}$ for all age groups combined (equivalent to 0.0005 to $0.0011 \mathrm{mg} / \mathrm{kg}$-day for a $10-\mathrm{kg}$ child) (DHHS, 1993c).

\section{Toxicity of lead}

Although the biological effects of lead in humans are fairly well defined, the precise exposure or doses associated with the effects are not well known. Dose-response data are available in terms of blood lead levels, rather than external exposure levels.

Lead and its compounds are cumulative toxicants. Lead may cause both acute and chronic effects, which usually result from its accumulation in the body over a period of time. The major effects are related to four organ systems: the hematopoietic, nervous, gastrointestinal, and renal systems.

Young children are inherently more susceptible to the effects of lead for the following reasons:

- Incomplete development of the blood-brain barrier at birth, increasing the risk of lead entering the central nervous system.

- Their greater lead intake in the gastrointestinal tract on a body-weight basis compared with adults.

- The greater absorption and retention rates of lead in children. 
- A greater prevalence of nutrient deficiency in children, which can affect gastrointestinal lead absorption.

- Differences in the efficiency of lead sequestration in bone.

Acute toxicity - The most common form of acute lead poisoning is gastrointestinal colic. Acute signs and symptoms of lead poisoning may result both from short-term massive exposure and from long-term lead intake. After an initial stage of anorexia, symptoms of dyspepsia and constipation develop; there is an attack of colic characterized by diffuse paroxysmal abdominal pain. Other signs are pale skin, slow pulse, and increased blood pressure. These signs and symptoms reflect the spasmodic contraction of smooth muscle, probably related to vagal irritation.

Acute lead encephalopathy in adults is rare, but numerous cases have been observed in children (Casarett and Doull, 1991; DHHS, 1993c; NAS, 1972). Severe forms of encephalopathy develop suddenly with the onset of seizures and delirium, often associated with papilledema, and may result in coma and/or cardiorespiratory arrest. Prodromal manifestations occur rarely, but some children may develop anemia and mild colic prior to the onset of the acute encephalopathy syndrome (which includes vomiting, apathy, drowsiness, stupor, ataxia, hyperactivity, and other neurological signs and symptoms). Lead concentrations in blood associated with acute encephalopathy ranged from about 80 to $100 \mu \mathrm{g} / 100 \mathrm{~mL}$ (DHHS, 1993c). In adults, signs and symptoms of encephalopathy were seen at blood lead levels of $50 \mu \mathrm{g} / 100 \mathrm{~mL}$ or higher following short-term exposures to lead.

Chronic toxicity - Chronic exposure to lead may affect the hematopoietic system, nervous system, gastrointestinal tract, kidney, liver, cardiovascular system, and endocrine organs. No visible thresholds have been demonstrated for the most sensitive effects of lead exposure in humans (i.e., heme synthesis, erythropoiesis, and neurobehavioral toxicity).

Anemia is a common sign among workers exposed to lead mainly by inhalation. Lead-induced anemia is micro- or normocytic and hypochromic, being caused by a combined effect of the inhibition of hemoglobin synthesis and shortened lifespan of circulating erythrocytes. No safe blood lead level has been demonstrated for hematological effects in children. Studies on adults indicate that blood lead levels as low as $3 \mu \mathrm{g} / 100 \mathrm{~mL}$ may produce hematological effects (e.g., decreased $\delta$-aminolevulinic acid dehydratase [ALAD] activity) (DHHS, 1993c). A lead oral intake level as low as $0.01 \mathrm{mg} / \mathrm{kg}$-day produced hematological effects in humans and laboratory animals (rats and monkeys) (DHHS, 1993c). The effects were manifested in decreased activities of certain enzymes (ALAD), increased levels of porphyrin and protoporphyrin IX in red blood cells, and impaired heme synthesis (DHHS, 1993c). When the lead blood level is about 70 to $80 \mu \mathrm{g} / 100 \mathrm{~mL}$ or more, manifest anemia may develop in some individuals (Casarett and Doull, 1991; DHHS, 1993c). However, good nutrition may prevent recognizable lead anemia. 
Increased lead absorption may affect both the central nervous system and the peripheral nervous system. Effects on the central nervous system manifest as encephalopathy. The severity of encephalopathy depends on a combination of factors, including intensity and duration of exposure and age. Milder central nervous system symptoms include mental deterioration, hyperkinetic or aggressive behavior, sleeping difficulties, and vomiting. No-effect lead blood levels for chronic encephalopathy were determined for children at about 50 to $60 \mu \mathrm{g} / 100 \mathrm{~mL}$ and for adults at about $80 \mu \mathrm{g} / 100 \mathrm{~mL}$ (DHHS, 1993c). Changes in neurobehavioral function, including slightly decreased performance on intelligence quotient (1Q) tests, were observed in children at blood lead levels as low as $6 \mu \mathrm{g} / 100 \mathrm{~mL}$, and blood lead levels at 10 to $15 \mu \mathrm{g} / 100 \mathrm{~mL}$ were associated with impaired mental development (DHHS, 1993c). Neurobehavioral testing has revealed an effect in adults at blood lead levels of 40 to $80 \mu \mathrm{g} / 100 \mathrm{~mL}$.

Chronic as well as short-term exposures to lead resulting in blood lead levels of 40 to $80 \mu \mathrm{g} / 100 \mathrm{~mL}$ produced neurological signs and symptoms in adults, including malaise, forgetfulness, irritability, lethargy, headache, fatigue, impotence, decreased libido, dizziness, weakness, and paresthesia (DHHS, 1993c). In children, neurological signs and symptoms other than encephalopathy were observed at blood lead levels of $60 \mu \mathrm{g} / 100 \mathrm{~mL}$ (DHHS, 1993c).

Neurobehavioral signs and symptoms appeared at a lead oral intake level of $0.01 \mathrm{mg} / \mathrm{kg}$-day in test animals (rats and monkeys administered lead acetate in drinking water) (DHHS, 1993c). These effects included disruption of conditioned responses and changes in motor activity. Serious neurobehavioral changes resulted from oral lead intake of $0.05 \mathrm{mg} / \mathrm{kg}$-day. Later adverse health effects included impairment in delayed changes of behavioral tasks, impairment of nonspatial discrimination, and impairment of operant learning. At higher lead intake levels, decreased muscle tonus and visual attentiveness were observed in these species (DHHS, 1993c). Reports on peripheral lead neuropathy are rare and are primarily from excessive occupational exposure. Peripheral neuropathy is characterized by motor nerve dysfunction. Sensory nerves are less sensitive to lead than motor nerves. Signs of peripheral lead neuropathy were observed in children with blood lead levels of $20 \mu \mathrm{g} / 100 \mathrm{~mL}$ and at $30 \mu \mathrm{g} / 100 \mathrm{~mL}$ in adults (DHHS, 1993c).

Quantitative information on lead hepatotoxicity in humans is lacking. Hepatotoxicity in rats resulted from exposure to lead in drinking water (as lead acetate) at intake levels as low as 0.01 to $0.05 \mathrm{mg} / \mathrm{kg}$-day (DHHS, 1993c). The effects included decreased glycogen, ribonucleic acid, and sulfhydryl groups, as well as alterations in activities of oxidizing enzymes and increased liver weight.

Long-term exposure to lead may give rise to the development of irreversible functional and morphological renal changes. These changes include intense interstitial fibrosis, tubular atrophy, and dilatation. The glomeruli may be involved at a relatively late stage (Casarett and Doull, 1991). Prolonged 
exposure to lead associated with lead blood levels above $70 \mu \mathrm{g} / 100 \mathrm{~mL}$ may result in chronic irreversible nephropathy (DHHS, 1993c), but little is known about the dose-effect or dose-response relationship of the nephrotoxicity of inorganic lead. However, blood lead levels at 18 to $26 \mu \mathrm{g} / 100 \mathrm{~mL}$ resulted in renal impairment with gout or hypertension.

Increased blood pressure is associated with lead blood concentrations possibly as low as $7 \mu \mathrm{g} / 100 \mathrm{~mL}$ (EPA, 1986; DHHS, 1993c). It appears that this relationship is particularly significant for middle-aged white males (aged 40 to 59). In laboratory animals (rats fed lead acetate in drinking water for up to 8 months), the cardiovascular effects manifested as increased systolic blood pressure were observed at lead intake levels of $0.01 \mathrm{mg} / \mathrm{kg}$-day (DHHS, 1993c).

Prenatal exposure to lead may be related to postnatal mental retardation, impaired postnatal neurobehavioral development, premature birth, and reduced birth weight (DHHS, 1993c).

Exposure to inorganic lead has been associated with cancers (renal tumors) in laboratory animals, but lead carcinogenicity in humans has not been demonstrated. Because there is sufficient evidence of lead carcinogenicity in animals and because human data are insufficient, it has been classified as a probable human carcinogen (EPA, 1994a; IARC, 1987).

Because some of the adverse health effects from oral lead exposures, particulariy hematological changes and changes in children's neurobehavioral development, may occur at intake levels so low they are essentially without threshold, the EPA considers it inappropriate to develop an oral RfD for inorganic lead (EPA, 1994a).

Figure 5.5 summarizes the health effects of lead as a function of dose.

\subsubsection{Manganese}

\section{Absorption}

Following ingestion, manganese absorption is homeostatically controlled: the absorption rate depends on both the amount ingested and the existing manganese levels in tissue. Adults absorb approximately 3 to 4 percent of dietary manganese (Saric, 1986). Manganese can be absorbed following exposure by inhalation, ingestion, and dermal contact. In humans, available data indicate that only 3 percent of an ingested dose of manganese chloride is absorbed (Mena et al., 1969). Manganese in water appears to be more efficiently absorbed than manganese in foodstuff (EPA, 1994a). The absorption rate is influenced by iron and other metals. In states of iron deficiency, manganese is actively absorbed from the intestine. Individuals with anemia can absorb more than twice the percentage of an ingested dose. However, in states of excess iron, manganese absorption is by diffusion only (Saric, 1986). High 


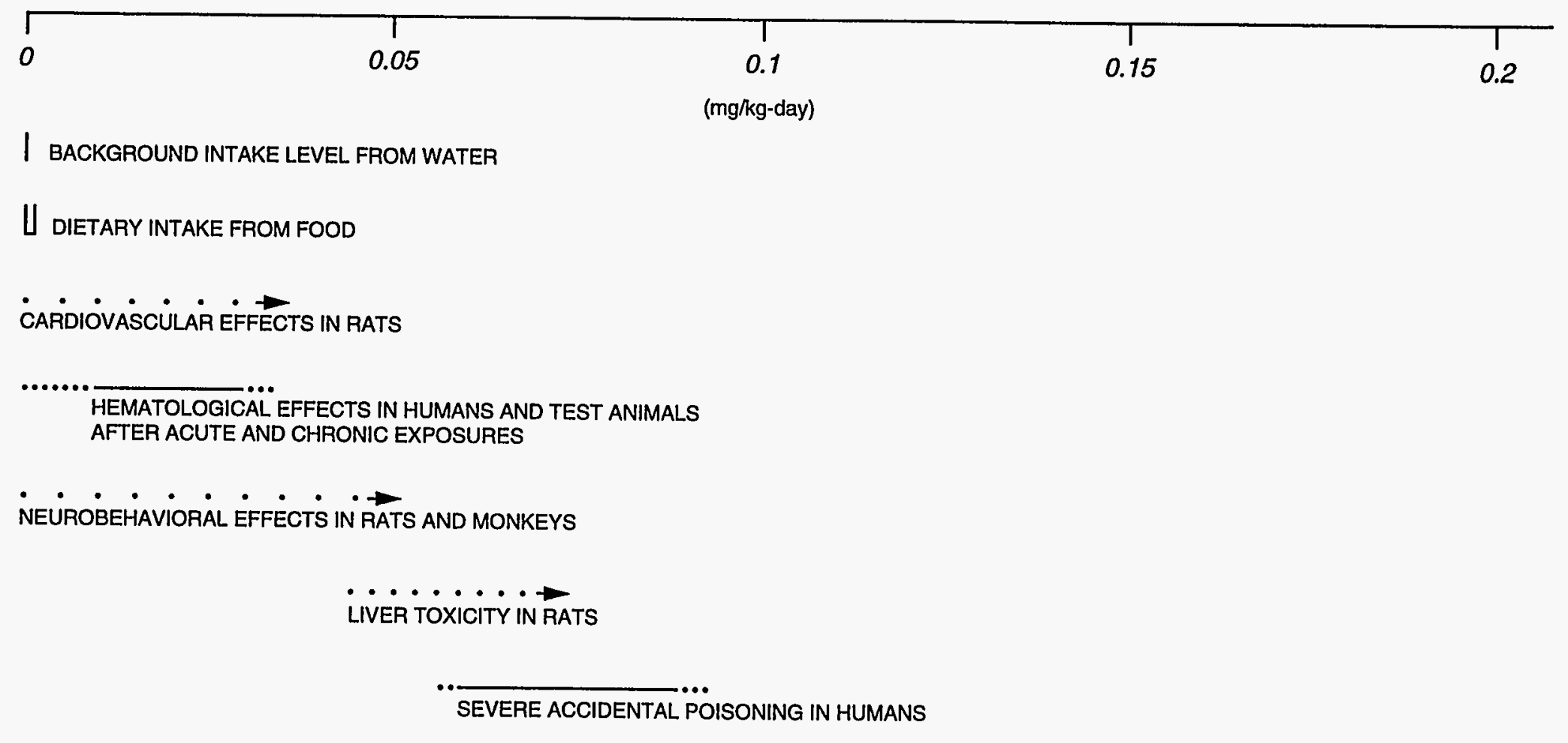

FIGURE 5.5

LEAD TOXICITY RANGES 
levels of dietary calcium and phosphorus are shown to increase the requirements for manganese in several species (Lönnerdal et al., 1987).

\section{Tissue accumulation and clearance}

Manganese is widely distributed throughout the body. The highest concentrations are found in the liver and kidney and, to a lesser extent, the hair. The biological half-time in humans is 2 to 5 weeks, depending on body stores. Manganese readily crosses the blood-brain barrier and is more slowly cleared from the brain than from other tissue (Goyer, 1991). Normal concentrations in the brain are low, but the half-time in the brain is longer and the metal may accumulate in the brain with excessive absorption (National Research Council, 1973).

Absorbed manganese is rapidly eliminated from the blood and concentrates in mitochondria. Initial concentrations are greatest in the liver. Manganese penetrates the placental barrier in all species and is more uniformly distributed throughout the fetus than in adults. It is secreted into milk.

Absorbed manganese is almost totally secreted in bile and reabsorbed from the intestine as needed to maintain body levels. At excessive exposure levels, other gastrointestinal routes may participate. Excess manganese is eliminated in the feces; urinary excretion is negligible (Goyer, 1991; Saric, 1986).

\section{Environmental sources of manganese}

On the whole, food constitutes the major source of manganese intake for humans. The highest manganese concentrations are found in plants, especially wheat and rice. Drinking water generally contains less than $0.1 \mathrm{mg} / \mathrm{L}$. Manganese levels in soil range from 1 to $7000 \mathrm{mg} / \mathrm{kg}$, with an average of 600 to $900 \mathrm{mg} / \mathrm{kg}$. Mining and natural geological background variations contribute to this variability. Manganese bioaccumulates in marine mollusks up to 12,000 fold, and there is evidence for toxic effects in plants (phytotoxicity) and plant bioaccumulation. The Illinois Institute for Environmental Quality has recommended a criterion of 1 to $2 \mathrm{mg} / \mathrm{kg}$ for manganese in soil and $200 \mathrm{mg} / \mathrm{kg}$ in plants (Saric, 1986).

Variations in manganese intake can be explained to a large extent by differences in nutritional habits. In populations using cereals and rice as main food sources, the intake will be higher than in areas where meat and dairy products are a larger part of the diet. The average daily intake has been estimated to be between 2.0 to $8.8 \mathrm{mg} /$ day (0.03 to $0.13 \mathrm{mg} / \mathrm{kg}$-day) (EPA, 1994a), but intakes as high as $12.4 \mathrm{mg}$ (about $0.2 \mathrm{mg} / \mathrm{kg}$-day) are reported in countries with high cereal intake (Saric, 1986).

Drinking water generally results in an intake of less than $0.2 \mathrm{mg}$ $(0.003 \mathrm{mg} / \mathrm{kg}$-day), although some mineral waters can increase this amount by more than threefold (Saric, 1986). One study from Greece reported drinking 
water concentrations of manganese in excess of $2 \mathrm{mg} / \mathrm{L}$, which would result in daily intakes in the range of 0.06 to $0.07 \mathrm{mg} / \mathrm{kg}$-day (EPA, 1994a).

\section{Toxicity of manganese}

Manganese is an essential nutrient. The adult estimated safe and adequate daily dietary intake ranges from 0.03 to $0.07 \mathrm{mg} / \mathrm{kg}$-day (Saric, 1986). The EPA noobserved-adverse-effect level (NOAEL) for drinking water is set at $0.005 \mathrm{mg} / \mathrm{kg}$-day, while the lowest-observed-adverse-effect level (LOAEL) for drinking water is $0.06 \mathrm{mg} / \mathrm{kg}$-day (EPA, 1994a). The EPA RfD for drinking water is $0.005 \mathrm{mg} / \mathrm{kg}$-day. The RfD for ingested food is $0.14 \mathrm{mg} / \mathrm{kg}$-day. Manganese in drinking water may be more bioavailable (i.e., more readily absorbed) than manganese in dietary food sources. This bioavailability would result in toxic effects at lower ingested doses in drinking water than in food (EPA, 1994a).

Industrial settings are the largest source of data on chronic manganese toxicity. The data indicate that inhalation of manganese can result in a central nervous system disorder characterized by irritability, difficulty in walking, speech disturbances, and compulsive behavior that may include running, fighting, and singing. With continued exposure, this condition can progress to a mask-like face, retropulsion or propulsion, and a Parkinson-like syndrome. These effects are largely irreversible, although some recovery can be expected when exposure ceases (DHHS, 1992b). Metal-chelating agents are ineffective in treatment, but L-dopa has been effective in treatment (Goyer, 1991).

Information on the effects of manganese ingestion is limited. Because effects from drinking water seem to differ from effects from food sources, only studies on water consumption will be considered here. A Japanese study of 25 people drinking well water with manganese concentrations of $14 \mathrm{mg} / \mathrm{L} 10.4 \mathrm{mg} / \mathrm{kg}$-day estimated intake) reported symptoms of intoxication, including a mask-like face, muscle rigidity and tremors, and mental disturbances. Two deaths ( 8 percent) occurred among the intoxicated people. A Greek study of more than 4000 adults at least 50 years old drinking water with manganese concentrations varying from 0.081 to $2.3 \mathrm{mg} / \mathrm{L}$ lestimated intakes at $2 \mathrm{~L} /$ day for a $70-\mathrm{kg}$ individual range from 0.002 to $0.07 \mathrm{mg} / \mathrm{kg}$-day) showed varying degrees of neurological effects in individuals drinking from 0.007 to $0.07 \mathrm{mg}$ manganese $/ \mathrm{kg}$-day, but no effects in individuals drinking less than 0.005 $\mathrm{mg} / \mathrm{kg}$-day (Kondakis et al., 1989). However, there are many limitations to these studies which make data interpretation difficult. Among the limitations is uncertainty regarding the exposure level or whether the effects seen were solely attributable to manganese. Despite these limitations, the similarity of the effects seen in the cases of oral exposure compared with those associated with inhalation exposure suggests that excess manganese intake by humans might lead to neurological injury (DHHS, 1992b).

The chemical form of manganese has complex effects on its toxicity. Although the more soluble forms are more readily absorbed from the gastrointestinal tract, 
they also appear to be more rapidly cleared. Exposure to insoluble forms results in lower manganese absorption but higher chronic tissue levels and therefore greater toxicity (EPA, 1994a). Information on the effects of various forms of manganese is limited.

Few data are available on manganese toxicity in infants, but infants are probably more susceptible to manganese toxicity due to greater absorption and greater penetration into the central nervous system (EPA, 1994a; Saric, 1986). Figure 5.6 summarizes manganese toxicity as a function of dose.

\subsubsection{Molybdenum}

\section{Absorption}

Molybdenum absorption in the gastrointestinal tract depends on the species of the metal. Inorganic hexavalent forms such as molybdenum trioxide, sodium molybdate, and ammonium molybdate are readily absorbed from both food and water, whereas molybdenite is not. Based on the geochemical models for the Durango site, all of the molybdenum exists in the form of well absorbable molybdate in ground water (Tables 3.11 through 3.14). Human absorption rates of 40 to 70 percent have been observed for the soluble forms of molybdenum (Tipton et al., 1969; Robinson et al., 1973; Alexander et al., 1974).

\section{Tissue accumulation and clearance}

In humans, the highest concentrations of molybdenum occur in the liver, kidney, and adrenals (Casarett and Doull, 1991). With normal dietary intake, molybdenum levels in the body slowly increase until approximately age 20 , then begin to decline steadily. Urine is the principal excretion route in humans. Human studies indicate that the biological half-life in humans is considerably longer than in animals and may be as long as 2 weeks (Rosoff and Spencer, 1964).

\section{Environmental sources of molybdenum}

Molybdenum occurs naturally in combination with other metals, including uranium, lead, iron, cobalt, and calcium. Native soil concentrations can vary by as much as 2 orders of magnitude, from 0.1 to $10 \mathrm{mg} / \mathrm{kg}$, leading to large variations in molybdenum concentrations in plant materials. Natural concentrations in ground water are reported from 0.00011 to $0.0062 \mathrm{mg} / \mathrm{L}$. Human dietary intake of molybdenum is estimated at 0.05 to $0.24 \mathrm{mg} / \mathrm{day}$ $(0.0007$ to $0.003 \mathrm{mg} / \mathrm{kg}$-day). The contribution of drinking water is estimated to range from 0 to 95 percent. The nutritional intake range for molybdenum is from 0.0015 to $0.0054 \mathrm{mg} / \mathrm{kg}$-day. No symptoms of molybdenum deficiency have been reported in humans. Nonetheless, molybdenum is an essential trace element that functions as a necessary constituent of several enzymes, including xanthine oxidase (which is involved in the metabolism of uric acid) and nitrate reductase (Friberg et al., 1986). 


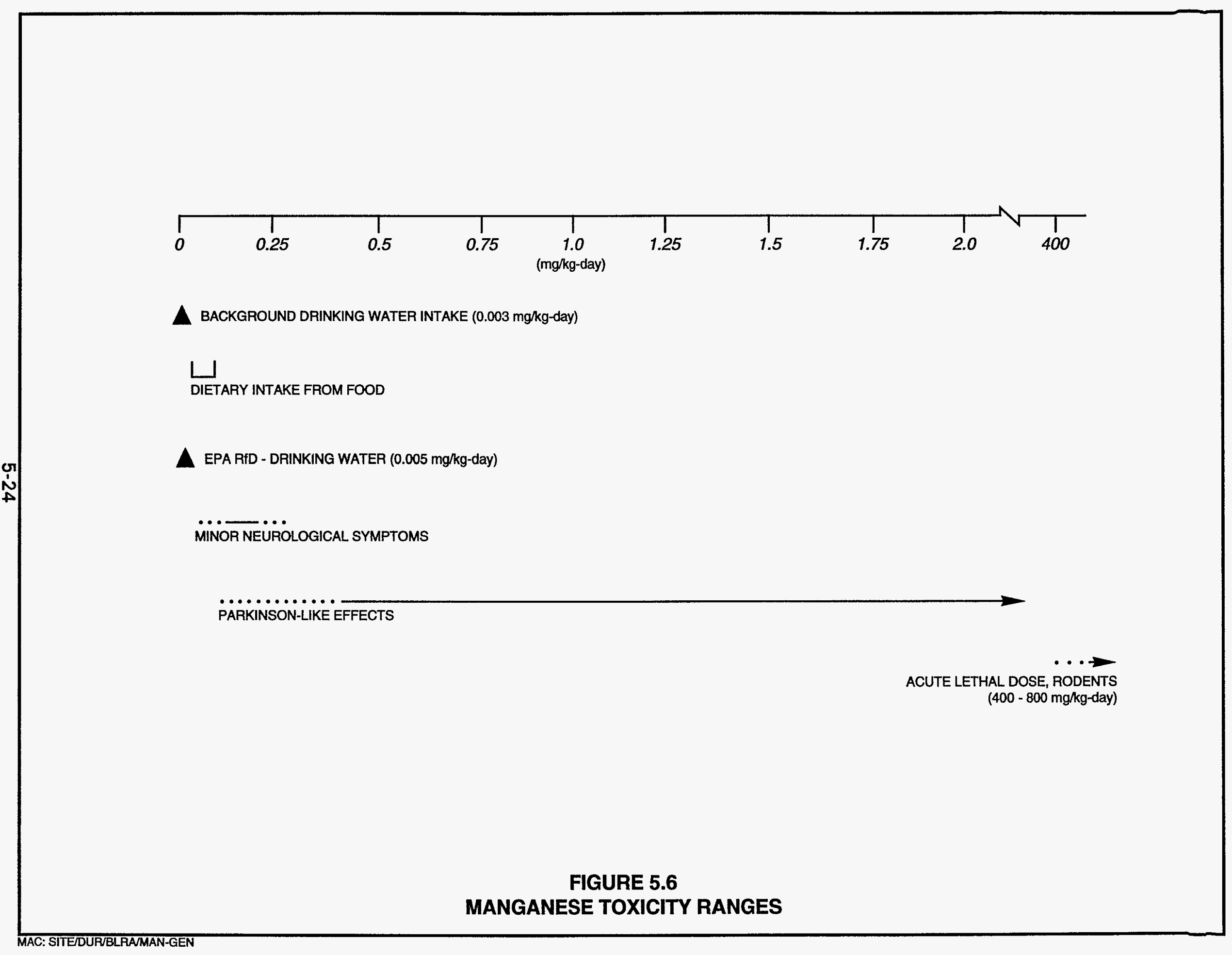




\section{Toxicity of molybdenum}

Acute toxic effects of molybdenum have not been reported. No adverse health effects have been reported with a chronic intake of less than $0.008 \mathrm{mg} / \mathrm{kg}$-day of molybdenum. Molybdenum toxicity primarily is related to its interactions with copper and sulfur, leading to altered excretion patterns for these elements. increased levels of molybdenum also increase the levels of xanthine oxidase, which is responsible for the production of uric acid. Uric acid can accumulate in joints, leading to symptoms of gout and other joint disorders.

A molybdenum intake of 0.008 to $0.022 \mathrm{mg} / \mathrm{kg}$-day can produce a mineral imbalance as a result of increased copper excretion. Copper excretion is reported to double with molybdenum intake at the upper end of this range. Copper is an essential nutrient important in many metabolic pathways, including the synthesis and function of hemoglobin. A copper deficiency resulting from excess excretion will impair the oxygen-carrying capacity of the blood, and severe copper deficiencies can lead to hypochromic microcytic anemia. In humans, gout-like symptoms and joint deformities are reported in regions of Russia where elevated molybdenum concentrations in soil and subsequent increased molybdenum concentrations in food lead to molybdenum intakes in the range of 0.14 to $0.21 \mathrm{mg} / \mathrm{kg}$-day. Figure 5.7 summarizes the health effects of molybdenum as a function of dose.

\subsubsection{Selenium}

\section{Absorption}

Although water-soluble forms of selenium such as selenite are approximately 90 percent absorbed in the gastrointestinal tract in rats, humans show lower percentages of absorption (40 to 80 percent) (Bopp et al., 1982). Absorption by ruminants is only 30 to 35 percent, probably due to bacterial reduction in the rumen. Absorption of the less soluble elemental selenium or selenium sulfide is poor in rats (Medinsky et al., 1981; Cummins and Kimura, 1971).

\section{Tissue accumulation and clearance}

Human studies suggest similar distributions of selenium between humans and laboratory animals (Bopp et al., 1982). At low intake levels, selenium is retained and accumulates in the reproductive organs, brain, and thymus, with only transient accumulation in other organs. Selenite-derived selenium accumulates in the liver and kidneys more rapidly than selenium derived from selenate (Millar et al., 1973). There is some indication that organically bound forms of selenium exist in a separate, more bioavailable pool than either selenite or selenate.

Although urinary excretion is the primary route of elimination under normal dietary conditions ( 67 percent), in deficiency states fecal excretion is the major pathway. At toxic doses, the major route of excretion is through expired air as 


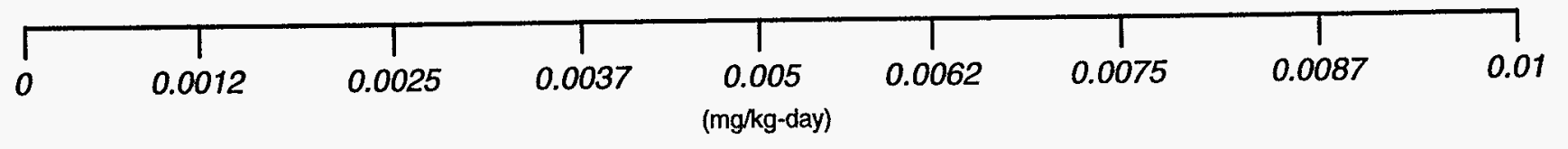

NUTRITIONAL REQUIREMENT

1

DIETARY INTAKE LEVELS

A ORAL RfD (0.005 mg/kg-day)

NO OBSERVED EFFECT LEVEL

MILD TOXICITY - INCREASED COPPER EXCRETION

AND URIC ACID SYNTHESIS ……... - GOUT

FIGURE 5.7

MOLYBDENUM TOXICITY RANGES 
dimethylselenide (50 to 60 percent) (Friberg et al., 1986). Although these data were obtained in rats, available data suggest that human excretion is similar (Bopp et al., 1982). The elimination of selenium in humans follows three phases with the following half-times: 1 day; 8 to 20 days; and 65 to 116 days.

\section{Environmental sources of selenium}

The main source of selenium for the general population is foods such as seafood, meat, and grains. Dietary intake of selenium in the United States ranges from 0.0007 to $0.0029 \mathrm{mg} / \mathrm{kg}$-day. Selenium concentrations in ground water and surface water range from 0.00006 to $0.400 \mathrm{mg} / \mathrm{L}$, with highs of $6 \mathrm{mg} / \mathrm{L}$ being reported (Friberg et al., 1986). Concentrations in U.S. public water supplies rarely exceed $0.010 \mathrm{mg} / \mathrm{L}$ (EPA, 1980). High selenium concentrations occur in volcanic rock $(0.120 \mathrm{mg}$ per gram) and in sandstone uranium deposits $(1.0 \mathrm{mg}$ per gram). The soil content of selenium varies widely, as does the rate of accumulation by plants. Although grasses and grains do not accumulate selenium in concentrations greater than $50 \mathrm{mg} / \mathrm{kg}$, some plants can accumulate as much as $10,000 \mathrm{mg} / \mathrm{kg}$ if grown in high-selenium regions. These high-accumulating plants are generally not used as food sources but can produce toxic effects if consumed by livestock.

\section{Toxicity of selenium}

Selenium is an essential nutrient. The RDA for adults is 0.0006 to $0.0011 \mathrm{mg} / \mathrm{kg}$-day. Although some biochemical alterations, including prolonged prothrombin time and reduced blood glutathione concentrations, can be observed with intakes of selenium from 0.0107 to $0.0121 \mathrm{mg} / \mathrm{kg}$-day, no clinical signs of selenosis are observed with these intakes. Mild toxicity, including hair loss or breakage, thickening and brittleness of nails, and a garlic odor in dermal excretions and breath, were reported in human populations with dietary intakes of selenium from $0.015 \mathrm{mg} / \mathrm{kg}$-day. However, selenium intake as low as $0.013 \mathrm{mg} / \mathrm{kg}$-day can produce symptoms of selenosis such as hair and nail loss in susceptible populations.

Persistent clinical symptoms of selenosis are attributed to the chronic dietary intake of selenium by human populations living in areas of China with high selenium concentrations in soil (from $7 \mathrm{mg} / \mathrm{kg}$ to $12 \mathrm{mg} / \mathrm{kg}$ ). Clinical signs observed included the characteristic garlic odor of excess selenium excretion in the breath and urine, thickened and brittle nails, hair and nail loss, lowered hemoglobin levels, mottled teeth, skin lesions, and central nervous system abnormalities (peripheral anesthesia, acroparesthesia, and pain in the extremities). Estimated selenium dietary intake was reported to be $0.018 \mathrm{mg} / \mathrm{kg}$-day for adult women and $0.021 \mathrm{mg} / \mathrm{kg}$-day for adult men (Yang et al., 1989a; 1989b). The average blood selenium concentration associated with this intake of selenium was $1.3 \mathrm{mg} / \mathrm{L}$ (ranging from $1.05 \mathrm{mg} / \mathrm{L}$ to $1.85 \mathrm{mg} / \mathrm{L}$ ). In the same study, symptoms of chronic selenosis (hair and nail loss and below-normal hemoglobin levels) were reported with a selenium intake of $0.071 \mathrm{mg} / \mathrm{kg}$-day. A serious outbreak of selenium poisoning, including the 
possible occurrence of neurotoxic effects such as peripheral anesthesia, acroparesthesia, and pain in extremities, was observed with selenium intake of $0.54 \mathrm{mg} / \mathrm{kg}$-day in both women and men. Protein intake by members of this population is unknown. These health effects are summarized in Figure 5.8 as a function of dose.

Ingestion of 350 to $4300 \mathrm{mg}$ (5 to $61 \mathrm{mg} / \mathrm{kg}$ ) of selenium by adults has produced vomiting, diarrhea, abdominal cramps, numbness in arms, and marked hair loss and irregular menstrual bleeding in women. Higher intakes can result in unsteady gait, cyanosis of mucous membranes, labored breathing, and sometimes death.

Symptoms of alkali disease and blind staggers have been seen in grazing livestock feeding over a long period of time upon selenium-accumulating plants in areas with high soil selenium content (Rosenfeld and Beath, 1964). These symptoms include neurological dysfunction such as impaired vision, ataxia, disorientation, and respiratory distress.

\subsubsection{Sodium}

\section{Absorption}

Sodium is rapidly and fully absorbed from the gastrointestinal tract. The skin and lungs also absorb sodium rapidly, by simple diffusion and ion exchange (National Research Council, 1980).

\section{Tissue accumulation and clearance}

Sodium is the major extracellular ion. The sodium ion is essential to the regulation of the acid-base balance and is an important contributor to extracellular osmolarity. It is an essential constituent in the electrophysiological functioning of cells and is required for impulse propagation in excitable tissues. Furthermore, sodium is essential for active nutrient transport, including the active transport of glucose across the intestinal mucosa. About 30 to 40 percent of the body's sodium is thought to be stored on the surfaces of the bone crystals, where it is easily recovered if blood sodium levels drop.

Sodium is excreted mainly in urine, with appreciable amounts also excreted in feces, sweat, and tears (Venugopal and Luckey, 1978). Mammalian renal sodium excretion is a two-phase process involving glomerular filtration and reabsorption in proximal tubules; of about 600 grams of sodium involved in 24-hour glomerular filtration, approximately 99.5 percent is reabsorbed in human adults. A homeostatic mechanism for sodium functions at the renal excretory level. 


\begin{tabular}{lllllllllll}
\hline & 0.0025 & 0.005 & 0.0075 & 0.01 & 0.0125 & 0.015 & 0.0175 & 0.020 \\
(mg/kg-day) & & & & &
\end{tabular}

NUTRITIONAL REQUIREMENT

DIETARY INTAKE LEVELS

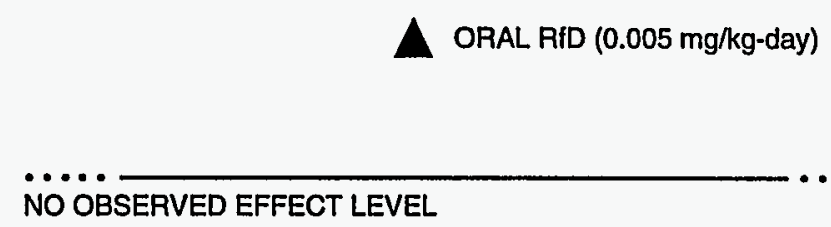

$\triangle$ ORAL RfD (0.005 mg/kg-day)

FIGURE 5.8

SELENIUM TOXICITY RANGES 


\section{Environmental sources of sodium}

The total sodium intake is influenced mainly by the amount of salt (sodium chloride) added to food, the inherent salt content of the foods consumed, and the amount of other sodium salts in the diet and in medication. Sodium is a natural constituent of both vegetable and animal products in varying concentrations. Other sources of sodium are drinking water, cooking water, soft drinks, and alcoholic beverages.

At 2 months, infants consume approximately $300 \mathrm{mg}$ of sodium a day; at 12 months, approximately $1400 \mathrm{mg} /$ day. Human breast milk contains $161 \mathrm{mg} / \mathrm{L}$, and cow's milk contains approximately $483 \mathrm{mg} / \mathrm{L}$ (Carson et al., 1986).

No RDA is set for sodium. The National Research Council recommends limiting daily sodium intake to less than $2400 \mathrm{mg}$ ( $34 \mathrm{mg} / \mathrm{kg}$-day); the American Heart Association recommends limiting dietary sodium intake to $3000 \mathrm{mg}$ daily. A healthy person requires about $115 \mathrm{mg}$ sodium daily $(1.6 \mathrm{mg} / \mathrm{kg}$-day), yet sodium dietary intake is estimated at 57 to $85 \mathrm{mg} / \mathrm{kg}$-day. However, dietary sodium intakes as high as $134 \mathrm{mg} / \mathrm{kg}$-day are reported (National Research Council, 1980).

The sodium content of drinking water is extremely variable. Analyses of water supply systems indicate sodium concentrations in 630 systems range from less than 1 to $402 \mathrm{mg} / \mathrm{L}$ (resulting in sodium intake from less than 0.03 to $11 \mathrm{mg} /$ $\mathrm{kg}$-day), with 42 percent greater than $20 \mathrm{mg} / \mathrm{L}$ and 3 percent over $200 \mathrm{mg} / \mathrm{L}$ (Carson et al., 1986).

\section{Toxicity of sodium}

Symptoms of acute sodium chloride toxicity accompanied by visible edema may occur in healthy adult males with an intake as low as 35 to 40 grams of salt per day $(200$ to $223 \mathrm{mg} / \mathrm{kg}$-day, because sodium is 39 percent of the weight of sodium chloride) (Meneely and Battarbee, 1976). The mean lethal dose of sodium for humans is reportedly $3230 \mathrm{mg} / \mathrm{kg}$ (Venugopal and Luckey, 1978).

Epidemiological studies indicate that long-term, excessive sodium intake is one of many factors associated with hypertension in humans. A high sodium-topotassium ratio in the diet may be detrimental to persons susceptible to high blood pressure. Some adults, however, tolerate chronic intake above 40 grams of sodium chloride per day (equivalent to $223 \mathrm{mg} / \mathrm{kg}$-day) (Carson et al., 1986).

Research indicates that critical levels of sodium ingestion cause blood pressure to rise with age, leading to hypertension. Freis (1976) reports that with sodium intake below $227 \mathrm{mg} / \mathrm{day}$ ( $3 \mathrm{mg} / \mathrm{kg}$-day for a $70-\mathrm{kg}$ adult), hypertension was absent. In the range of 227 to $1591 \mathrm{mg} /$ day $(3$ to $23 \mathrm{mg} / \mathrm{kg}$-day for a $70-\mathrm{kg}$ adult), a few cases of hypertension may appear, while in the range of 1591 to $8000 \mathrm{mg} /$ day (23 to $114 \mathrm{mg} / \mathrm{kg}$-day for a 70-kg adult), approximately 15 percent of adults exhibit hypertension. When sodium intake rises above 
$8000 \mathrm{mg} / \mathrm{day}$, hypertension may be found in about 30 percent of the population. Because sodium chloride is present in nearly all processed and packaged foods, limiting dietary intake is difficult. The average daily dietary intake in the United States often causes hypertensive effects.

Drinking water generally contains relatively low levels of sodium and therefore does not significantly contribute to the total intake unless sodium is at higherthan-average levels in the water supply. However, people on sodium-restricted diets can obtain a significant portion of daily sodium from drinking water. Because the kidney is the major organ involved in regulating sodium balance, individuals with compromised kidney function may be placed on a low-sodium diet. Other individuals may be on low-sodium diets to control hypertension. Because of the high prevalence of such individuals in our society, the American Heart Association has proposed that public drinking water supplies in the United States adopt a standard of $20 \mathrm{mg} / \mathrm{L}$ sodium (Calabrese and Tuthill, 1977). This standard measure would limit the additional intake of sodium from drinking water to approximately $0.6 \mathrm{mg} / \mathrm{kg}$-day for a $70-\mathrm{kg}$ adult. Figure 5.9 summarizes the potential health effects of sodium as a function of dose.

\subsubsection{Sulfate}

\section{Absorption}

Sulfate absorption from the gastrointestinal tract is similar in humans and other animals. Generally, greater than 90 percent absorption is reported for sulfate doses below $150 \mathrm{mg} / \mathrm{kg}$, decreasing to 50 to 75 percent as the dose increases into the grams-per-kilogram range.

\section{Tissue accumulation and retention}

Ingesting high levels of sulfate results in transient increases in both blood and urine concentrations. Approximately 50 percent of a $75-\mathrm{mg} / \mathrm{kg}$ dose is excreted over 72 hours. The urinary excretion mechanism is transport-limited and can become saturated at high doses of sulfate. Excess sulfate is also excreted in feces in its inorganic form. To date, no data indicate that sulfate accumulates, even with chronic ingestion of above-normal levels. However, extremely high chronic doses have not been examined in humans.

Sulfate is used to biosynthesize collagen, cartilage, and dentin and to form sulfate esters of both endogenous compounds (such as lipids and steroids) and exogenous compounds (such as phenols). Sulfation is important in detoxication pathways because it increases the solubility of these compounds, enhancing their excretion in the urine. Exposure to high concentrations of compounds that are conjugated with sulfate and excreted can produce a transient decrease in plasma sulfate concentrations. 


\begin{tabular}{|c|c|c|c|c|c|c|c|c|c|}
\hline$\Gamma$ & $T$ & $T$ & $T$ & $T$ & $T$ & $T$ & $T$ & $T$ & $T$ \\
\hline 0 & 10 & 20 & 30 & 40 & $\begin{array}{r}50 \\
(\mathrm{mg} / \mathrm{kg}\end{array}$ & 60 & 70 & 80 & 90 \\
\hline
\end{tabular}

$\underbrace{}_{\text {BACKGROUND INTAKE LEVELS FROM DRINKING WATER }}$

$\triangle$ NUTRITIONAL REQUIREMENT

$\triangle$ NRG-RECOMMENDED UPPER LIMIT FOR DIETARY INTAKE

DIETARY INTAKE LEVELS

HYPERTENSION MAY OCCUR IN HUMANS

FIGURE 5.9

SODIUM TOXICITY RANGES 


\section{Environmental sources of sulfate}

In 1978, drinking water sulfate concentrations in the western United States (EPA, 1992a) ranged from 0 to $820 \mathrm{mg} / \mathrm{L}$, with a mean concentration of $99 \mathrm{mg} / \mathrm{L}$. The EPA estimates a normal sulfate intake range of 0.00023 to $0.0064 \mathrm{mg} / \mathrm{kg}$-day from air and up to $2.9 \mathrm{mg} / \mathrm{kg}$-day from drinking water in the western United States. Estimates on sulfate intake from food are not available.

\section{Toxicity of sulfate}

The acute and chronic effects of sulfate toxicity differ more in severity than in symptoms or mechanisms. Therefore, this discussion will combine acute and chronic toxicity. As discussed above, no data indicate sulfate bioaccumulation with chronic exposure. Sulfate salts of magnesium and sodium are used medicinally as cathartics. High concentrations of unabsorbed sulfate salts in the gut can pull large amounts of water into the gut, greatly increasing the normal volume of feces. This action is also the basis of sulfate's toxic effects.

Toxicity in humans is primarily manifested in diarrhea; the severity of the diarrhea is dose-dependent. Chronic sulfate ingestion can result in persistent diarrhea, leading to ionic imbalance and dehydration similar to that seen with extremely high acute doses. Serious gastroenteritis is reported in some infants and adults drinking water containing 400 to $1000 \mathrm{mg} / \mathrm{L}$ sulfate (EPA, 1992a). When drinking water is contaminated with sulfate, the taste of the water may make it unpalatable and reduce consumption. However, this is not necessarily the case. In regions with high sulfate concentrations in the drinking water (such as Saskatchewan), residents adapt to the taste and find the water palatable (EPA, 1992a). A lower water intake could compound the dehydration effects of the diarrhea. Extreme dehydration can lead to death. As with nitrate toxicity, infants appear to be the most susceptible population for sulfate-induced diarrhea. Also, some data indicate that diabetic and elderly populations with compromised kidney function may be more sensitive than healthy adults to the effects of sulfates (EPA, 1992a). Figure 5.10 summarizes these health effects as a function of dose.

Sulfate toxicity data are based primarily on epidemiologic studies of human adults and infants who report to hospitals with symptoms of sulfate exposure. In most cases, exposure doses have been back-calculated from sampling their drinking water. Therefore, these data do not represent well-controlled studies with readily defined dosage ranges.

\subsubsection{Thallium}

\section{Absorption}

Exposure to thallium may occur by inhalation, ingestion, or dermal absorption. However, ingestion appears to be the predominant route of exposure for humans (DHHS, 1992c). 


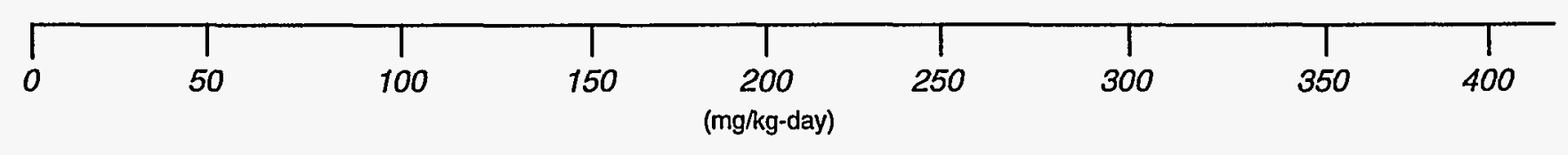

ப

BACKGROUND INTAKE LEVELS

LO ÖBSERVED EFFECTS

MiLD TOXICITY RANGING FROM LAXATIVE EFFECT IN ADULTS TO DIARRHEA IN INFANTS

SEVERE TOXICITY - PERSISTENT INFANT DIARRHEA LEADING TO DEHYDRATION $\cdots$-... DEATH

FIGURE 5.10

SULFATE TOXICITY RANGES 
Limited data exist regarding thallium absorption in humans after oral exposure (DHHS, 1992c), although the data suggest that most of a dose of thallium given orally (thallium nitrate and sulfate) to a patient with terminal osteogenic sarcoma was absorbed. Animal data suggest that thallium may be completely absorbed from the gastrointestinal tract (DHHS, 1992c).

\section{Tissue accumulation and clearance}

Once absorbed, thallium is distributed throughout the body. The highest tissue concentrations following poisoning in humans are in the scalp hair and kidney (DHHS, 1992c; Casarett and Doull, 1991). The intestine, thyroid, testes, pancreas, skin, bone, and spleen have lesser amounts of accumulated thallium. Brain and liver thallium levels are still lower.

In animals, thallium distribution from the bloodstream is rapid and widespread (DHHS, 1992c). In rats administered approximately $1.4 \mathrm{mg}$ thallium $/ \mathrm{kg}$ (as thallium sulfate) in drinking water, thallium accumulated in the kidney, followed by the heart, brain, bone, skin, and blood. The biological half-life for thallium was approximately 3 days, following a single orally administered dose of thallium-204 (as thallium nitrate) to rats (DHHS, 1992c).

Following the initial exposure, large amounts of thallium are excreted in urine during the first 24 hours; then, excretion is slow and the feces may be an important route of excretion (Casarett and Doull, 1991). In humans, about 15 percent of administered radioactive thallium was detected in urine in 5.5 days and 0.4 percent in feces in 3 days after the dose was administered (DHHS, 1992c). An excretion half-life of about 22 days was estimated. Thallium is also excreted in hair (DHHS, 1992c).

\section{Environmental sources of thallium}

Compounds of thallium are generally soluble in water. Thallium tends to be sorbed to soils and sediments and to bioconcentrate in aquatic plants, invertebrates, and fish (DHHS, 1992c). Terrestrial plants can also absorb thallium from soil; in this way, it enters the terrestrial food chain.

Thallium has been used medicinally as a depilatory (Casarett and Doull, 1991). Thallium compounds, mainly thallous sulfate, have been used as rat poison and insecticides.

The general population is exposed to thallium most frequently by ingesting thallium-containing foods, especially home-grown fruits and green vegetables (DHHS, 1992c). The typical thallium concentration in food is up to $0.05 \mathrm{mg} / \mathrm{kg}$, and the estimated typical thallium daily intake from food by a 70-kg adult is $0.005 \mathrm{mg}$, assuming intake of food at $1.5 \mathrm{~kg} /$ day by a $70-\mathrm{kg}$ adult and an absorption fraction of 1.0 (equivalent to $0.00007 \mathrm{mg} / \mathrm{kg}$-day). 
Because thallium is a naturally occurring element, it may be present in ambient waters in trace amounts (DHHS, 1992c). A survey of tap water from 3834 homes in the United States detected thallium in 0.68 percent of samples at an average concentration of $0.89 \mu \mathrm{g} / \mathrm{L}$ (the estimated typical thallium intake by a $70-\mathrm{kg}$ adult is about $0.00003 \mathrm{mg} / \mathrm{kg}$-day, assuming ingestion of $2 \mathrm{~L}$ of water per day).

\section{Toxicity of thallium}

Thallium is one of the more toxic metals (Casarett and Doull, 1991). It can cause neural, hepatic, and renal injury. It may also cause deafness and loss of vision and hair.

The use of thallium compounds as a rat poison and insecticides is one of the commonest sources of thallium poisoning. Acute thallium poisoning in humans is characterized by gastrointestinal irritation, acute ascending paralysis, and psychotic disturbances (Casarett and Doull, 1991; DHHS, 1992c). Thallium was lethal in humans following acute oral exposure at doses of 54 to $110 \mathrm{mg}$ thallium $/ \mathrm{kg}$ of body weight as thallium sulfate (DHHS, 1992c). The estimated lethal dose of thallium for the average adult is approximately 14 to $15 \mathrm{mg} / \mathrm{kg}$. This dose range also produced severe cranial and peripheral neuropathy, tubular necrosis, centrilobular necrosis of the liver with fatty changes, myocardial damage and electrocardiographic changes, and alveolar damage (hyaline membrane formation and pulmonary edema). The kidney toxicity of thallium is reportedly due to infarction rather than a direct effect on kidney tissue. Renal function is also impaired following thallium exposure (DHHS, 1992c). The acute cardiovascular effects of thallium ions probably result from competition with potassium for membrane transport systems, inhibition of mitochondrial oxidative phosphorylation, and disruption of protein synthesis (Casarett and Doull, 1991). Thallium also alters heme metabolism. At oral doses as low as $0.08 \mathrm{mg} / \mathrm{kg}$-day, thallium (as thallous suifate administered by gavage) produced developmental effects (manifested as performance deficit) in rats following acute exposure (DHHS, 1992c). The lowest lethal dose of thallium of $5 \mathrm{mg} / \mathrm{kg}$ is determined for guinea pigs (DHHS, 1992c).

Fatty infiltration and necrosis of the liver, nephritis, gastroenteritis, pulmonary edema, degenerative changes in the adrenals, degeneration of the peripheral and central nervous systems, alopecia (hair loss), and in some cases death have been reported in humans as a result of long-term systemic thallium intake. These cases usually are caused by ingestion of contaminated food or the use of thallium as depilatory (DHHS, 1992c; Casarett and Doull, 1991). Peripheral neuropathy was reported in 189 cases of thallium poisoning in China from 1960 to 1977 (DHHS, 1992c). This adverse health effect was attributed to ingestion of cabbage grown in thallium-contaminated gardens. However, the dose-effect relationship has not been determined from these studies. 
Dark pigmentation of hair roots and hair loss are common features of thallium exposure (DHHS, 1992c; Casarett and Doull, 1991). Hair loss can occur as early as 8 days after exposure. The effect is reversible.

The signs of subacute or chronic thallium exposure in rats were hair loss (at doses equal to or less than $1.2 \mathrm{mg}$ thallium $/ \mathrm{kg}$-day, as thallium acetate or thallium oxide) (DHHS, 1992c), cataracts, and hindleg paralysis occurring with some delay after the initiation of dosing (Casarett and Doull, 1991). Following treatment with $1.4 \mathrm{mg}$ thallium/ $\mathrm{kg}$-day (as thallium sulfate administered in drinking water), structural and functional changes were observed in peripheral nerves in rats at 240 days (DHHS, 1992c). Renal lesions were also observed; however, the oral intake level producing this effect could not be determined. Histologic changes revealed damage of the proximal and distal renal tubules. Mitochondria in the kidney and liver revealed degenerative changes. Similar mitochondrial changes were observed in the intestine, brain, seminal vesicle, and pancreas. It has been suggested that thallium may combine with the sulfhydryl groups in the mitochondria and thereby interfere with oxidative phosphorylation. A teratogenic response to thallium salts manifested as achondroplasia (dwarfism) has been described in rats.

Animal studies revealed abnormalities in testicular morphology, function, or biochemistry in rats received approximately $0.7 \mathrm{mg}$ thallium $/ \mathrm{kg}$-day as thallium sulfate during a 60-day treatment period (DHHS, 1992c). Reproductive effects have not been found in humans after oral exposure to thallium.

The EPA chronic oral RfD of thallium as low as $0.00008 \mathrm{mg} / \mathrm{kg}$-day has been derived from the NOAEL determined in the oral subchronic study in rats (EPA, 1994a). The subchronic oral RfD has been established for thallium at 0.0008 $\mathrm{mg} / \mathrm{kg}$-day (EPA, 1994b). Figure 5.11 summarizes the health effects of thallium as a function of dose.

\subsubsection{Uranium}

The uranium that occurs naturally at UMTRA Project sites consists of three radioactive isotopes: uranium-234, uranium-235, and uranium-238. More than 99 percent of natural uranium occurs in the form of uranium-238 (Cothern and Lappenbusch, 1983). Uranium-238 undergoes radioactive decay by emitting alpha particles to form uranium-234, thorium-230, radium-226, radon-222, polonium-210, lead-210, and other radioisotopes. Figure 5.12 summarizes the radioactive decay chain of uranium-238 and uranium-234. Because all natural uranium isotopes are radioactive, the hazards of a high uranium intake are from both its chemical toxicity and its potential radiological damage. The chemical toxicity of natural uranium is discussed here; the carcinogenic potential associated with exposure to radioactive isotopes of natural uranium is discussed in Section 5.3. 


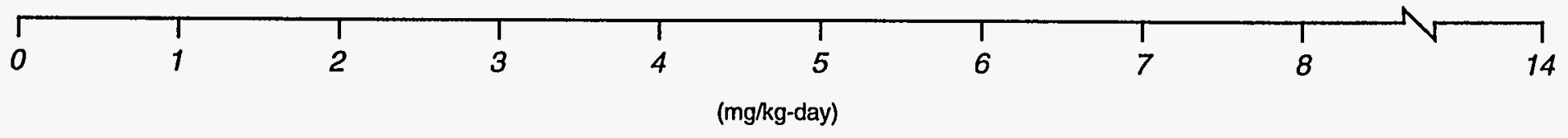

I BACKGROUND INTAKE LEVEL FROM DRINKING WATER AND FOOD

$\triangle$ CHRONIC ORAL RfD $(0.00008 \mathrm{mg} / \mathrm{kg}$-day $)$

A SUBCHRONIC ORAL RfD (0.0008 mg/kg-day)

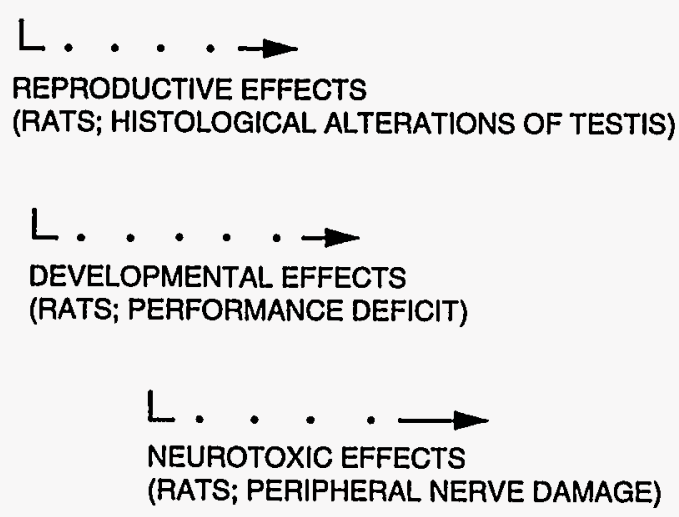

A LOWESt lethal dose IN GUINEA PIG

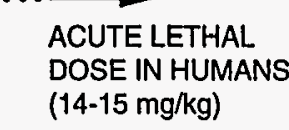

FIGURE 5.11

THALLIUM TOXICITY RANGES 


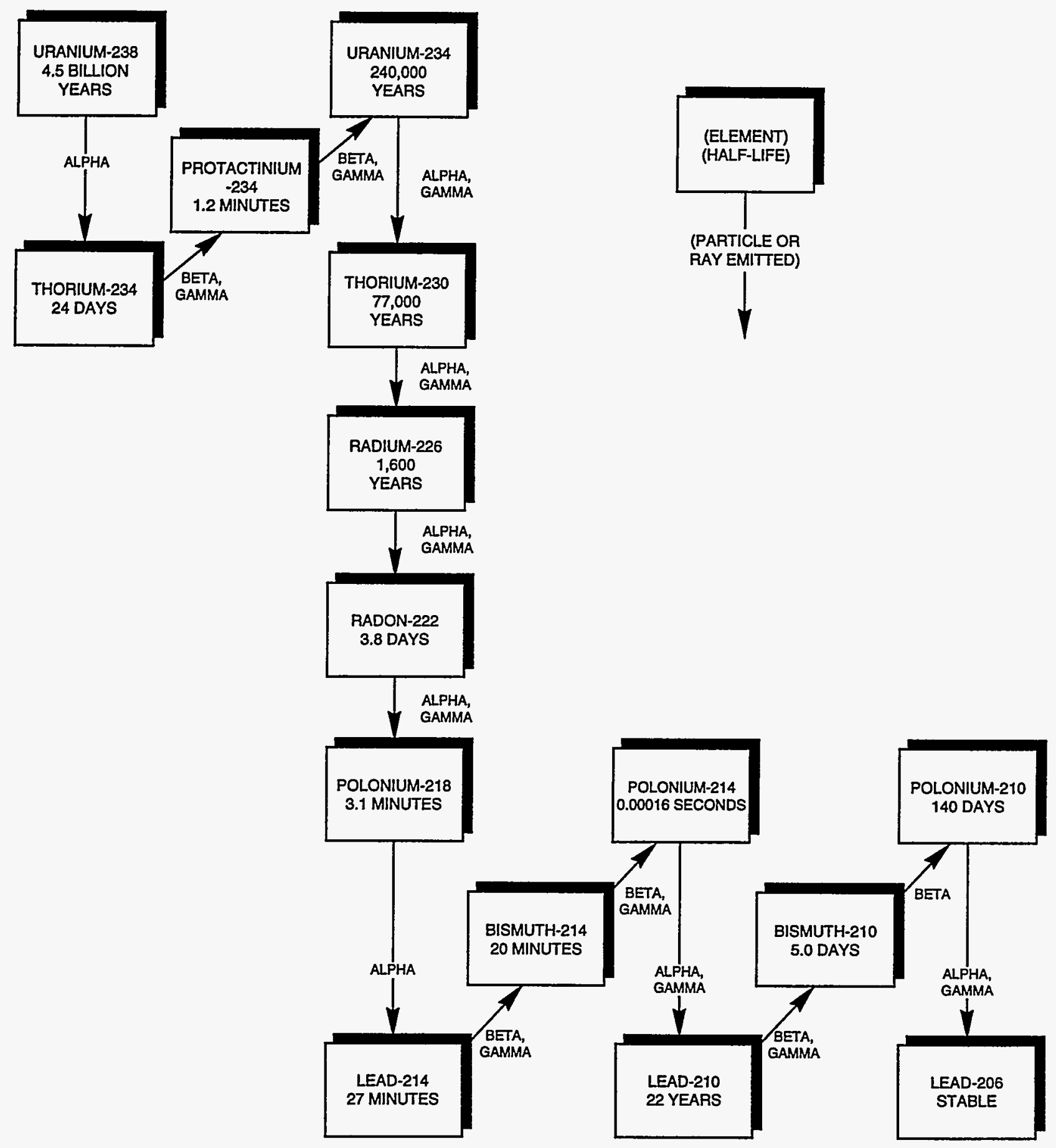

FIGURE 5.12

HALF-LIVES AND EMISSIONS FROM DECAY CHAIN OF URANIUM-238 


\section{Absorption}

Uranium absorption in the gastrointestinal tract depends on the solubility of the uranium compounds. The hexavalent uranium compounds, especially the uranyl salts, are water soluble, while tetravalent compounds generally are not (Weigel, 1983). However, only a small fraction of the soluble compounds is absorbed. Wrenn et al. (1985) have determined human gastrointestinal absorption rates of 0.76 to 7.8 percent.

Uranium may absorb through the skin when applied in concentrated solutions (the concentration level was not reported). The extent of absorption appears to be dose-dependent.

\section{Tissue accumulation and clearance}

In humans exposed to background levels of uranium, the highest concentrations were found in the bones, muscles, lungs, liver, and kidneys (Fisenne et al., 1988). Uranium retention in bone consists of a short retention half-time of 20 days, followed by a long retention half-time of 5000 days for the remainder (Tracy et al., 1992).

In body fluids, uranium tends to convert into water-soluble hexavalent uranium (Berlin and Rudell, 1986). Approximately 60 percent of the uranium in plasma complexes with low-molecular-weight anions (e.g., bicarbonates, citrates), while the remaining 40 percent binds to the plasma protein transferrin (Stevens et al., 1980). Following oral exposure to uranium, humans excrete more than 90 percent of the dose in the feces. Of the small percent that is absorbed (typically less than 5 percent), animal studies show that approximately 60 percent is excreted through the urine within 24 hours, whereas the remainder is distributed to the skeleton and soft tissue; 98 percent of that amount is excreted within 7 days (Ballou et al., 1986; Leach et al., 1984; Sullivan et al., 1986). A small portion of the absorbed uranium is retained for a longer period.

\section{Environmental sources of uranium}

Uranium is a ubiquitous element, present in the earth's crust at approximately 4 parts per million (ppm). Uranium concentrations in ground water and surface water average 1 picocurie per liter $(\mathrm{pCi} / \mathrm{L})$ and $3 \mathrm{pCi} / \mathrm{L}$, respectively (NCRP, 1984). The extent of uptake from the soil into plant tissues depends on the plant species and the depth of its root system (Berlin and Rudell, 1986). Tracy et al. (1983) report plant uranium concentrations averaging $0.075 \mu \mathrm{g} / \mathrm{kg}$ of fresh plant material.

The main dietary source of natural uranium for the general population is food (e.g., potatoes, grains, meat, and fresh fish) that may contain uranium concentrations between 10 and $100 \mu \mathrm{g} / \mathrm{kg}$ (Prister, 1969). The total uranium dietary intake from consuming average foods is approximately $1 \mu \mathrm{g} / \mathrm{day}$; 
approximately 20 to 50 percent of that total can come from drinking water. Cereals and vegetables, particularly root crops, probably contribute most to daily uranium intake (Berlin and Rudell, 1986).

\section{Toxicity of uranium}

No human deaths are reported that are definitely attributable to uranium ingestion; therefore, no lethal dose has been determined for humans. Lethal doses of uranium $\left(L D_{50,23}\right)$ are reported to be as low as $14 \mathrm{mg} / \mathrm{kg}$-day following 23-day oral exposure, depending on the solubility of the uranium compound tested (higher solubility compounds have greater toxicity), exposure route, and animal species. High doses of uranium cause complete kidney and respiratory failure.

No chronic toxic effects are reported in humans following oral exposure to uranium. Data from populations occupationally exposed to high concentrations of uranium compounds through inhalation and information from studies on experimental animals indicate that the critical organ for chronic uranium toxicity is the proximal tubule of the kidney (Friberg et al., 1986). In humans, chemical injury reveals itself by increased catalase excretion in urine and proteinuria. Dose-response data for the toxic effects of uranium on the human kidney are limited.

The lowest dose of uranyl nitrate that caused moderate renal damage was given to rabbits in diet at $2.8 \mathrm{mg} / \mathrm{kg}$-day (Maynard and Hodge, 1949). Figure 5.13 summarizes the health effects of uranium as a function of dose.

\subsubsection{Vanadium}

\section{Absorption}

Absorption of vanadium from the gastrointestinal tract is low. The International Commission on Radiological Protection estimate for the absorption of soluble vanadium compounds is 2 percent (ICRP, 1960), but the WHO states that absorption of even very soluble forms of vanadium is less than 1 percent from the gastrointestinal tract (WHO, 1988). Limited human data (from three individuals) have suggested that as much as 10 percent of a repeated oral dose may be absorbed (Proescher et al., 1917; Tipton et al., 1969). Soluble vanadium compounds that are inhaled and deposited are more readily absorbed (about 25 percent) (WHO, 1988). Although soluble forms of vanadium may be absorbed through the skin, absorption via this route is probably minimal (EPA, 1977; WHO, 1988).

\section{Tissue accumulation and clearance}

Vanadium is found in all body tissues in concentrations ranging from $0.08 \mu \mathrm{g}$ per gram wet weight in spleen tissue to $0.14 \mu \mathrm{g}$ per gram in brain and heart tissue and $0.33 \mu \mathrm{g}$ per gram in aorta tissue (Yakawa and Suzuki-Yasumoto, 


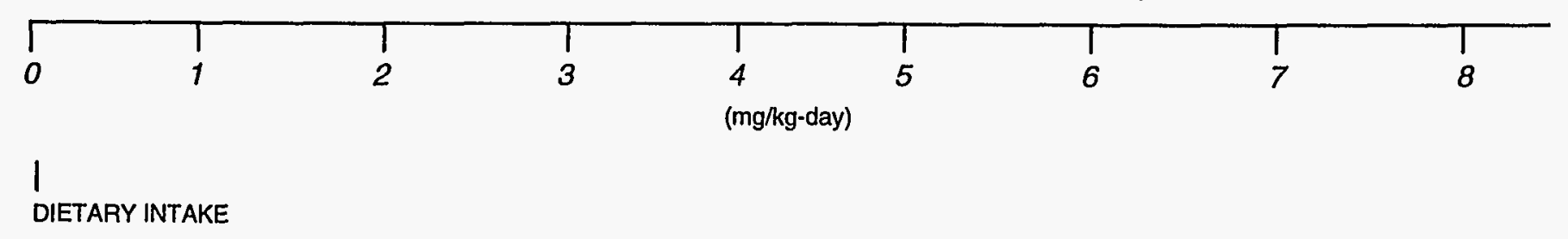

A ORAL RfD (0.003 mg/kg-day)

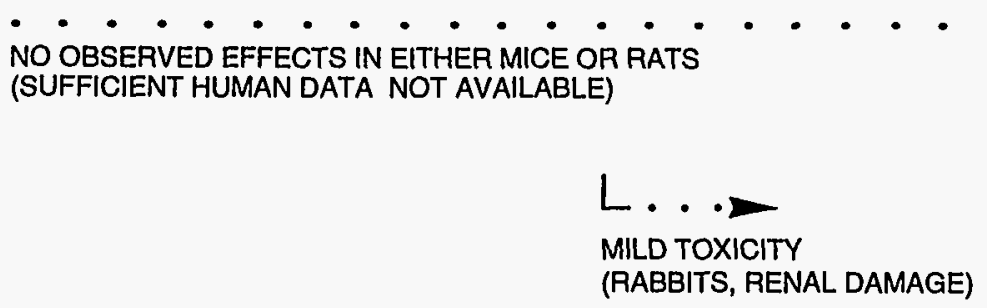

FIGURE 5.13

URANIUM TOXICITY RANGES 
1980). Concentrations of vanadium in human blood serum are reported to be 0.016 to 0.939 nanograms per milliliter $(\mathrm{ng} / \mathrm{mL})$. In hair, concentrations of vanadium ranging from 20 to $60 \mathrm{ng}$ per gram have been reported by different authors, with higher values found in manic-depressive patients (57 ng per gram) than in normal control groups (29 ng per gram).

The distribution of vanadium in humans following oral exposure may be extrapolated from animal studies. In acute-duration exposures, vanadium is rapidly distributed, primarily in the bones. After intermediate-duration exposure, vanadium concentrations reaching the tissues are low, with the kidneys, bones, liver, and lungs initially showing the highest levels.

Vanadium is an element and is not metabolized. However, in the body, there is an interconversion of two oxidation states of vanadium: vanadyl and vanadate. Vanadium can reversibly bind to the protein transferrin in the blood and then be taken up into erythrocytes. There is a slower uptake of vanadyl into erythrocytes compared to the vanadate form, possibly due to the time required for the vanadyl form to be oxidized to vanadate. Initially, vanadyl leaves the blood more rapidly than vanadate, possibly because of the slower vanadyl uptake into cells (Harris et al., 1984). Five hours after administration, blood clearance is essentially identical for the two forms.

Because vanadium is poorly absorbed in the gastrointestinal tract, a large percentage of vanadium in rats is excreted unabsorbed in the feces following oral exposure. In rats, the principal route of excretion of the small absorbed portion of vanadium is through the kidneys. The mean urinary output per 24 hours is reported to be $10 \mu \mathrm{g}$.

\section{Environmental sources of vanadium}

Elemental vanadium does not occur in nature, but its compounds exist in more than 50 different mineral ores and in association with fossil fuels. The single largest release of vanadium to the atmosphere occurs through the combustion of fossil fuels, particularly residual fuel oils. The largest amount of vanadium released to soil and water occurs through natural weathering of geological formations (Byerrum et al., 1974; Van Zinderen Bakker and Jaworski, 1980).

Food constitutes the major source of exposure to vanadium for the general population (Lagerkvist et al., 1986). As a whole, dietary intake is estimated to be 6 to $18 \mu \mathrm{g} /$ day (Pennington and Jones, 1987), although other estimates from older studies using different (and possibly less sensitive) analytical methods have been as high as $2 \mathrm{mg} /$ day (Schroeder et al., 1963).

Drinking water is not considered an important source of vanadium exposure for the general population. Water samples taken from across the United States show 92 percent with values below $10 \mu \mathrm{g} / \mathrm{L}$. Typical values appear to be around $1 \mu \mathrm{g} / \mathrm{L}$ (Lagerkvist et al., 1986). The estimated daily intake of vanadium by inhalation is $1 \mu \mathrm{g}$ (Byrne and Kosta, 1978). 
Although vanadium is considered an essential element for chickens and rats, there is no certainty about human dietary requirements. For animals, the daily requirement is about 10 to $25 \mu \mathrm{g} /$ day (Pennington and Jones, 1987).

\section{Toxicity of vanadium}

The major adverse health effect to humans from vanadium is seen in workers exposed to large amounts of vanadium pentoxide dusts. The probable oral lethal dose of vanadium pentoxide for humans is between 5 and $50 \mathrm{mg} / \mathrm{kg}$ (Gosselin et al., 1976).

Systemic effects of vanadium exposure have been observed in the liver, kidneys, nervous and cardiovascular systems, and blood-forming organs. Metabolic effects include interference with the biosynthesis of cystine and cholesterol, depression and stimulation of phospholipid synthesis, and, at higher concentrations, inhibition of serotonin oxidation. Other effects of vanadium on mammalian metabolism include depression of phospholipid synthesis (Snyder and Cornatzer, 1958), reduction of coenzyme $Q$ levels in mitochondria (Aiyar and Sreenivasan, 1961), and stimulation of monoamine oxidase, which oxidizes serotonin (Perry et al., 1955).

Vanadium salts were given to patients in several studies to reduce cholesterol levels (Curran et al., 1959; Somerville and Davies, 1962; Dimond et al., 1963; Schroeder et al., 1963). The doses of vanadium in these studies varied from 7 to $30 \mathrm{mg} /$ day. Transient decreases in serum cholesterol levels were observed in some patients, as were loosened stool and cramps. Green tongue, a hallmark of vanadium exposure, was observed in all patients.

A relationship between the concentration of vanadium in drinking water and the incidence of dental caries in children is reported by Tank and Storvick (1960). Dental caries incidence in children aged 7 to 11 years was reduced three times (compared to controls) by applying ammonium vanadate in glycerol to the teeth (Belehova, 1969). This relationship was not found in other studies (Hadjimarkos, 1966; 1968).

It has been suggested that raised tissue levels of vanadium are important in the etiology of manic-depressive illness. Improvement after treatment with ascorbic acid or reduced vanadium intake was seen both in manic and depressed patients.

Although animal studies have reported impaired conditioned reflexes following doses of vanadium from $0.05 \mathrm{mg} / \mathrm{kg}$-day (after 6 months of exposure) to $0.5 \mathrm{mg} / \mathrm{kg}$-day (after 21 days of exposure), effects on the nervous system have not been observed following repeated oral administration of vanadium in humans. Workers exposed by inhalation to fairly high concentrations of vanadium compounds have reported nonspecific symptoms, including headache, weakness, vomiting, nausea, and ringing of the ears (WHO, 1988). 
Available data on vanadium toxicity are insufficient to evaluate its effect on cholesterol levels, iron metabolism, blood-cell production, and mutagenesis. However, due to poor absorption from the gut, the metal is not considered very toxic following oral administration (WHO, 1988). The EPA oral RfD of 0.007 $\mathrm{mg} / \mathrm{kg}$-day was obtained from a chronic drinking water study with vanadium sulfate in rats (EPA, 1987; EPA, 1994b). The toxicity of vanadium is summarized in Figure 5.14.

\subsection{CONTAMINANT INTERACTIONS}

Some information is available on potential interactions between contaminants found at UMTRA Project sites. However, discussions of potential interactions can generally be presented only qualitatively. In addition to physiological variables between individuals that can affect toxicity, uncertainties in interactions also result from 1) differences in the relative exposure concentrations of the different contaminants compared to the concentrations tested experimentally; and 2) the presence of additional ground water constituents in sufficient quantities to modify predicted toxicities even though they themselves are not considered contaminants of potential concern for human health. Therefore, the interactions described below should be recognized as factors that can influence the predicted toxicity, although the precise nature and magnitude of that influence cannot be determined.

A primary concern at the Durango site is the potential for interactions between metals. Interactions between several similar metals can alter the predicted absorption, distribution in the body, metabolism, clearance, or toxicity of a metal of interest.

For example, cadmium, manganese, and selenium absorption can be considerably altered under conditions of high calcium and iron or a low-protein diet (Elinder, 1986; Nordberg et al., 1985). Absorption of cadmium, manganese, and selenium from the intestine may significantly decrease (up to fourfold in the case of cadmium) in the presence of high dietary iron, leading to decreased toxicity of cadmium, manganese, and selenium (DHHS, 1992b). High levels of cadmium may inhibit manganese uptake. Conversely, high levels of manganese lead to decreased iron absorption. Short-term effects of this type are probably the result of kinetic competition between iron and manganese for a limited number of binding sites on intestinal transport enzymes, while longerterm effects of iron excess are probably due to adaptive changes in the level of intestinal transport capacity. On the other hand, iron deficiency anemia llow iron body stores) may substantially increase the gastrointestinal absorption of cadmium, lead, and manganese, resulting in higher body burden and toxicity from these elements.

Because cadmium, calcium, strontium, and lead are competitive with respect to their absorptive sites, an excess of any of these elements may partially inhibit the absorption of others. Excess lead may decrease calcium absorption through competition for a common transport system, and it may substitute in the bone 


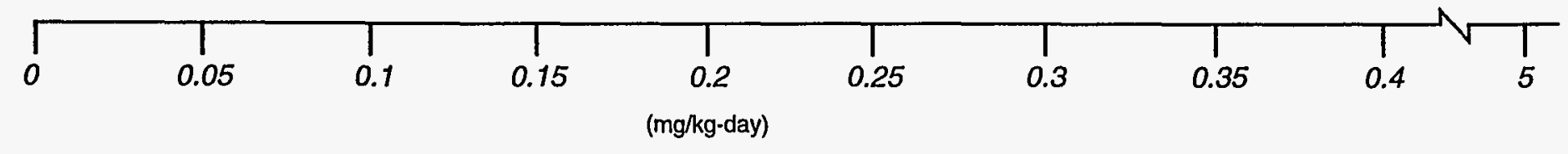

| DIETARY INTAKE

A ORAL RfD - DRINKING WATER (0.007 mg/kg-day) IMPAIRED CONDITIONED REFLEXES (RATS)

TRANSIENT CHOLESTEROL DROP, CRAMPS, GREEN TONGUE 
for calcium. Thus, lead storage sites in the bone may form a continuous internal source of lead exposure, even after external exposure ceases.

In addition, cadmium and manganese can induce synthesis of the metal-binding protein metallothionein (DHHS, 1992b; Casarett and Doull, 1991). The formation of metallothionein-manganese complex would enhance manganese excretion, decreasing its toxicity. This protein, however, seems to have a paradoxical effect on the systemic toxicity of cadmium. Metallothionein appears to bind cadmium and, in this way, protect certain organs, such as testes, from cadmium toxicity. But, at the same time, metallothionein may enhance cadmium nephrotoxicity, possibly because the cadmium-metallothionein complex is taken up by the kidney more readily than is the free ion. However, because both cadmium and manganese bind to metallothionein, in the continued presence of both cadmium and manganese there may be competition for metallothionein-binding sites.

A single study in mice suggests that vanadium and manganese interact, producing some alterations in behavioral development of the pups as compared to either element administered alone (DHHS, 1992b). Oral administration of vanadium alone may interfere with copper metabolism by inhibiting the intestinal absorption of copper, leading to copper deficiency. Copper deficiency may be triggered by the presence of molybdenum at levels observed at the Durango site.

Selenium interacts with a wide range of elements, including arsenic, cadmium, cobalt, copper, lead, silver, and thallium (Friberg et al., 1986). Selenium forms insoluble complexes with silver, copper, and cadmium. Selenium deficiency may develop in the presence of these other metals, as is seen with cobalt and copper. The formation of these complexes may reduce the toxicity of both selenium and the other metal (Casarett and Doull, 1991). Most of these interactions have been observed in laboratory animals or in livestock. The mechanisms are not completely understood in many cases. Often the seleniummetal complex binds in a stable complex to a larger protein than the metal alone, and a redistribution of this complex occurs away from the target tissues. Selenium and arsenic together can reduce their respective toxicities. However, some methylated metabolites of selenium can increase the toxicity of arsenic (DHHS, 1989). Sulfate can also interact with selenium, but the result of interaction is inconsistent. Sulfate can reduce some toxic effects of selenium, but not others such as liver damage at high doses of selenium (DHHS, 1989).

Sulfate also interacts in a complex manner with molybdenum and copper. Molybdenum excretion is affected by copper and sulfate. Sulfate reduces molybdenum accumulation by competing for protein carriers and enhances its excretion by inhibiting tubular reabsorption. Ruminants seem to be the most susceptible species to imbalances between these elements. In ruminants, copper prevents the accumulation of molybdenum in the liver and may antagonize absorption of molybdenum from food. Molybdenum can produce a functional copper deficiency. The antagonism of molybdenum to copper is 
augmented by sulfate. It has also been suggested that sulfide (a reduced form of sulfate) can displace molybdate in the body (Casarett and Doull, 1991). In laboratory animal models, the toxicity of molybdenum is more pronounced in situations where dietary copper intake is low (EPA, 1994a). In ruminants, copper sulfate can protect against molybdenum toxicity, and molybdenum and sulfur can inhibit copper toxicity.

Because ingesting high levels of sulfate and magnesium produces diarrhea that leads to dehydration, and ingesting high levels of sodium and chloride leads to water retention, a physiological interaction might be expected to occur with simultaneous ingestion of all of them. However, available data do not predict the net effects of chronic ingestion of sulfate and sodium chloride at high concentrations. Although high-concentration sodium chloride solutions are used to treat diarrhea-induced hyponatremia and hypochloremic metabolic alkalosis, the electrolyte concentrations in these solutions are physiologically balanced. Disproportionately high sodium and chloride levels could intensify the electrolyte loss produced by severe diarrhea.

Trace metals can influence the toxicity of thallium (DHHS, 1992c). Potassium has been shown to increase renal excretion of thallium, decrease the degenerative effects of thallium on epiphyseal cartilage in mouse limb cultures, decrease placental transport of thallium, and increase the lethality of thallium in animals. However, the degree of relevance of these findings to human situations has not been definitely determined.

In animal studies, iron status affected the gastrointestinal absorption of uranium; however, the reported results were inconclusive (EPA, 1989c). No other information has been found on interactions of uranium with other metals. However, the common target organ suggests that uranium, arsenic, cadmium, lead, vanadium, molybdenum, and manganese interact to enhance kidney toxicity.

No information on the influence of other compounds on the toxicity of antimony was found.

Finally, diarrhea-induced dehydration may cause contaminants excreted in urine to concentrate in the kidney. Thus, diarrhea-induced dehydration may enhance the predicted toxicities of these contaminants.

\subsection{CONTAMINANT RISK FACTORS}

The EPA Office of Research and Development has calculated acceptable intake values, or RfDs, for long-term (chronic) exposure to noncarcinogens. These values are estimates of route-specific exposure levels that would not be expected to cause adverse effects when exposure occurs for a significant portion of the lifetime. Some of the chronic RfDs are adopted as subchronic RfDs. The RfDs include safety factors to account for uncertainties associated with limitations of the toxicological database. These safety factors include 
extrapolating results from animal studies to humans and accounting for response variabilities in sensitive individuals. These values are updated quarterly and are published in the Health Effects Assessment Summary Tables (HEAST). Following more stringent review, they are published through the EPA'S IRIS database. The most recent oral RfDs for the noncarcinogenic contaminants of potential concern are summarized in Table 5.2 .

The EPA currently classifies all radionuclides as Group A, or known human carcinogens, based on their property of emitting ionizing radiation and on evidence provided by epidemiological studies of radiation-induced cancer in humans. At sufficiently high doses, ionizing radiation acts as a complete carcinogen (both initiator and promoter), capable of increasing the probability of cancer development. However, the actual risk is difficult to estimate, particularly for the low doses and dose rates encountered in the environment. Most of the reliable data were obtained under conditions of high doses delivered acutely. It is not clear whether cancer risks at lower doses are doseproportional (i.e., the linear dose-response hypothesis) or whether the risk is greatly reduced at low doses and rates (i.e., the threshold hypothesis). A conservative assumption rejects the threshold hypothesis and assumes that any dose and dose rate add to the risk of cancer.

Risk factors published in HEAST and IRIS correlate the intake of carcinogens over a lifetime with the increased excess cancer risk from that exposure. The most recent cancer SFs for the uranium-234/-238 radioactive decay series and the chemical carcinogen arsenic are given in Table 5.1 . 


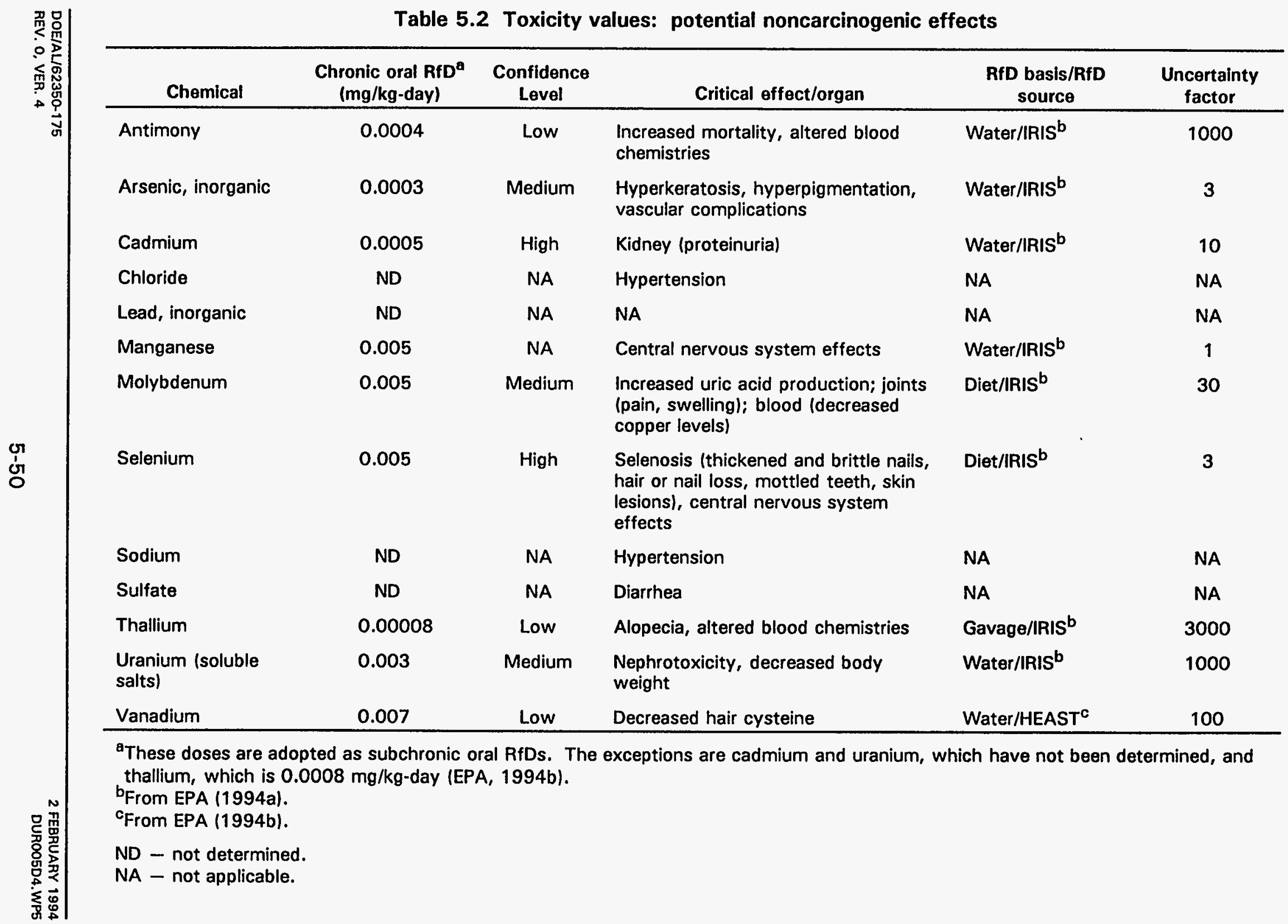




\subsection{HUMAN HEALTH RISK EVALUATION}

Health risks to an individual or population are evaluated by combining the results of both the exposure and toxicity assessments. As discussed in Section 5.0, potential adverse health effects depend on the amount of the contaminant an individual takes into his or her body. At lower levels, many contaminants associated with the processing are beneficial to health, because they are essential nutrients. At higher levels, these same elements can cause adverse health effects.

\subsection{POTENTIAL NONCARCINOGENIC HEALTH EFFECTS}

Eight contaminants of potential concern for the mill tailings area (cadmium, manganese, molybdenum, selenium, sodium, sulfate, uranium, and vanadium) and five for the raffinate ponds area (chloride, manganese, sodium, sulfate, and uranium) are evaluated probabilistically. The remaining contaminants of potential concern (antimony and lead for the mill tailings area and antimony, arsenic, cadmium, lead, molybdenum, selenium, and thallium for the raffinate ponds area) are evaluated by comparing estimated daily intake values to the acceptable intake levels recommended by the EPA (oral RfD values), as well as to toxicity ranges.

The results from the exposure assessment showing either the highest intake-tobody-weight ratios (i.e., highest doses) or the toxicologically most sensitive group are used to evaluate potential health effects of noncarcinogens. For antimony, arsenic, cadmium, chloride, lead, manganese, molybdenum, selenium, sodium, thallium, uranium, and vanadium, the highest intake-per-body-weight group is children 1 to 10 years old. Infant exposures are used to evaluate the health risks of sulfate exposure, because this is the most toxicologically sensitive population.

Exposure to sulfate presents the most significant health risk associated with the contaminated ground water at the Durango processing site. As can be seen in Figure 6.1A for the mill tailings area, almost 100 percent of the exposure distribution for sulfate is in the range where mild diarrhea would be expected in infants, and about 60 percent of the expected exposures would be in the range of severe diarrhea, which can lead to dehydration. The risk could be more serious at the raffinate ponds area, where almost the entire exposure distribution for sulfate is within the range where severe diarrhea, with resulting dehydration and potentially death, would be expected in infants (Figure 6.1B). Further, these effects would be expected after very short-term exposures. However, these high sulfate concentrations may cause the water to be unpalatable to infants, thus reducing their exposure.

Because the predicted sulfate toxicity from drinking water is so severe, and because this is the only exposure pathway for infants, any additive contribution from other dietary or environmental sources would not alter the interpretation of health risks. 


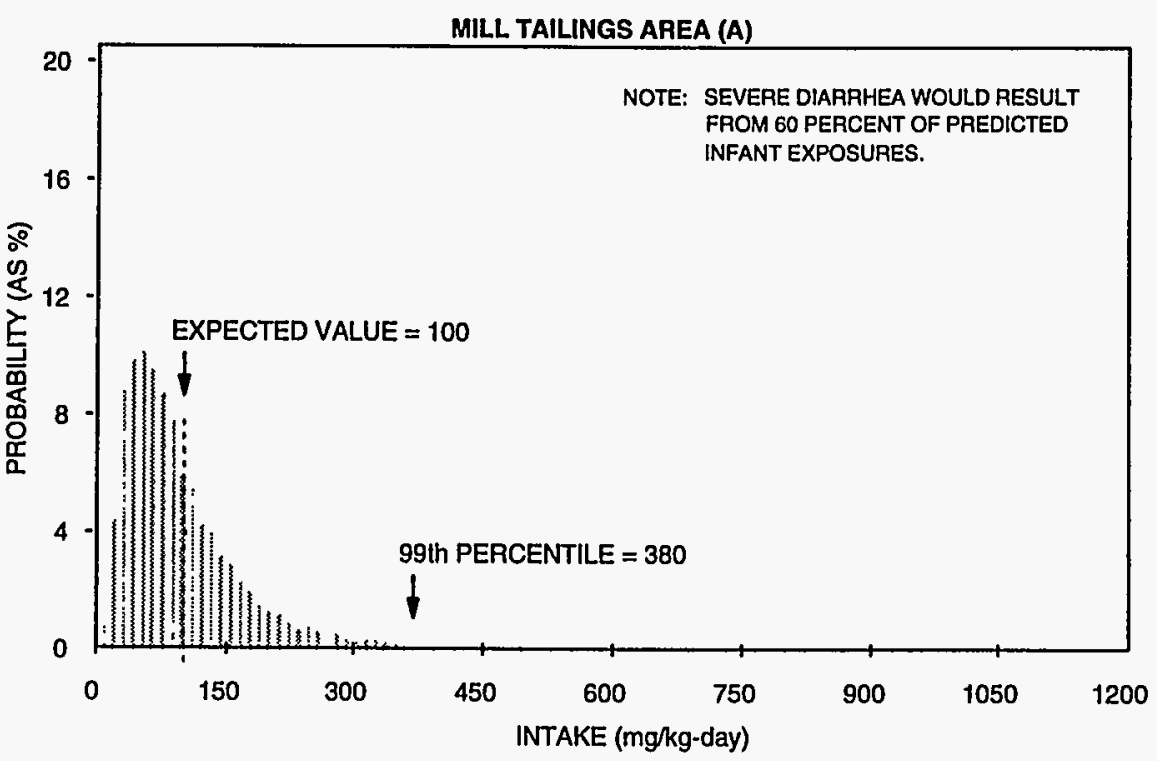

U BACKGROUND INTAKE LEVELS

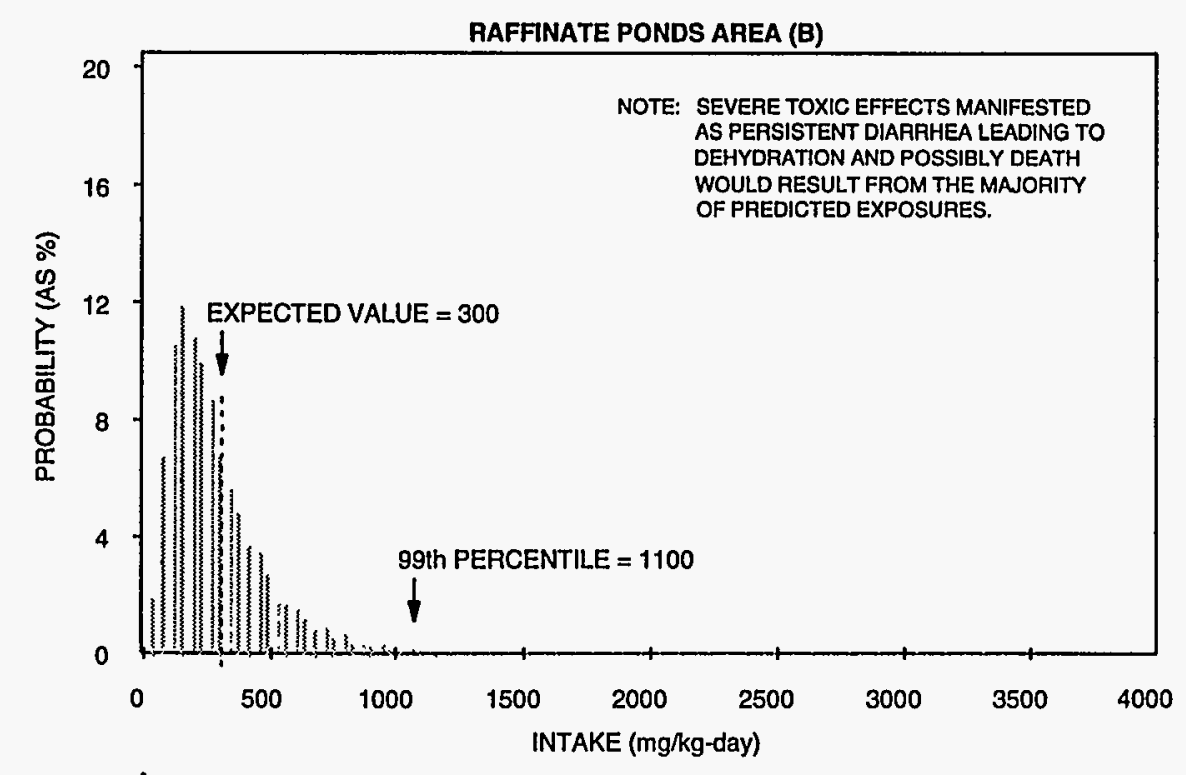

- J MILD TOXICTYY

(LAXATIVE EFFECT IN ADULTS; DIARRHEA IN INFANTS)

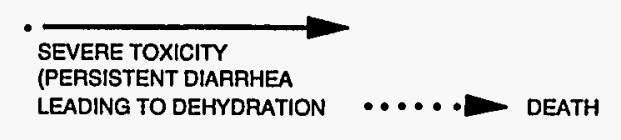

I BACKgRound INTAKE LEVELS

\section{$\checkmark$ MILD TOXICITY}

(LAXATIVE EFFECT IN ADULTS; DIARRHEA IN INFANTS)

SEVERE TOXICITY (PERSISTENT DIARRHEA

LEADING TO DEHYDRATION … DEATH

FIGURE 6.1

HEALTH EFFECTS OF POTENTIAL SULFATE EXPOSURE RANGES FOR INFANTS DURANGO, COLORADO, SITE 
The exposure distribution for infants is based on tap water intake rates across a population that includes breast-fed and canned-formula-fed infants. Infants consuming powdered or concentrated formula reconstituted with well water would be in the upper percentiles of this exposure distribution and would be at higher risk of severe diarrhea.

Drinking ground water, especially at the raffinate ponds area, would lead to acute toxicity due to sulfate levels, which could preclude chronic exposures. However, because different ground water contaminants flush out at different rates and because remedial action strategies may differ for different contaminants, the effects from long-term exposures to contaminants other than sulfate are also discussed.

The entire exposure distributions for manganese (Figure 6.2A and $\mathrm{B}$ ) are above the threshold level of mild neurological symptoms and above the EPA RfD derived from drinking water consumption studies for both the mill tailings and raffinate ponds areas. Approximately 10 percent of these exposure distributions are above the threshold level of Parkinson-like disease. As discussed in Section 5.1.6, infants may be more susceptible to manganese toxicity than children and adults. Therefore, toxic effects may appear in infants at levels lower than those in Section 5.1.6.

Chronic sodium exposures would be associated with the development of hypertension in children as well as in adults. The adverse health effects could be more serious from exposure to sodium-contaminated ground water at the raffinate ponds area than the mill tailings area. As can be seen in Figure 6.3A for the mill tailings area, 60 percent of the exposure distribution for sodium is above the threshold level of hypertension in humans. For the raffinate ponds area, 99 percent of the exposure distribution for sodium could be associated with hypertension (Figure 6.3B). In addition, chloride exposure from contaminated ground water at the raffinate ponds area and, to a lesser extent, at the mill tailings area may contribute to the development of hypertension. At the raffinate ponds area, about 70 percent of the exposure distribution for chloride alone may be associated with hypertension in sensitive individuals (Figure 6.4), although some uncertainty is associated with these studies. Renal insufficiency would augment this health effect.

About 40 percent of the molybdenum intake distribution from contaminated ground water at the mill tailings area falls above the acceptable intake level recommended by the EPA (RfD of $0.005 \mathrm{mg} / \mathrm{kg}$-day). However, only 15 percent of this intake is above the threshold level of mild toxicity, which may manifest as copper deficiency and increased production of uric acid (Figure 6.5). The estimated molybdenum exposure levels for the raffinate ponds area (Table 6.1) are twice the EPA oral RfD and could be associated with mild toxicity resulting from copper deficiency (Section 5.1.7) if ground water were ingested for long periods of time. 

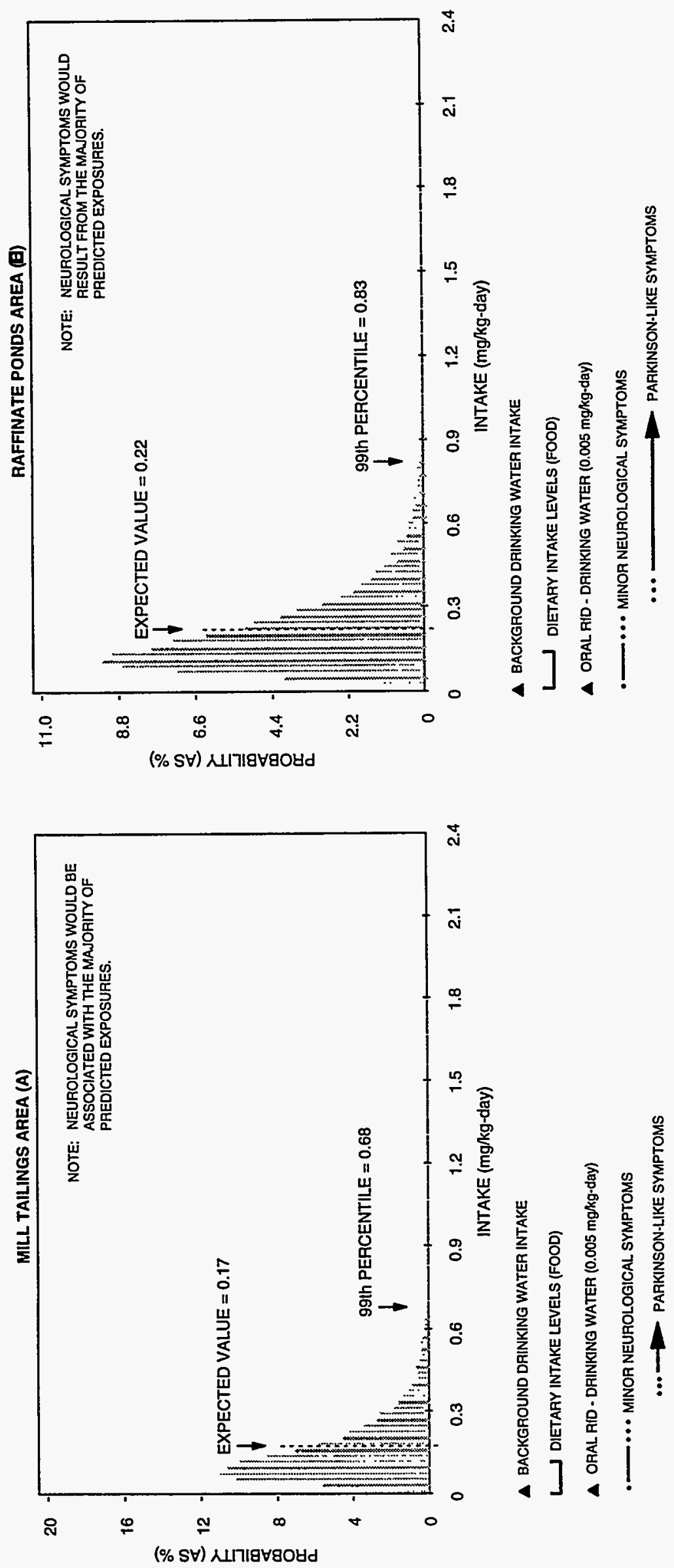


\section{MILL. TAILINGS AREA (A)}

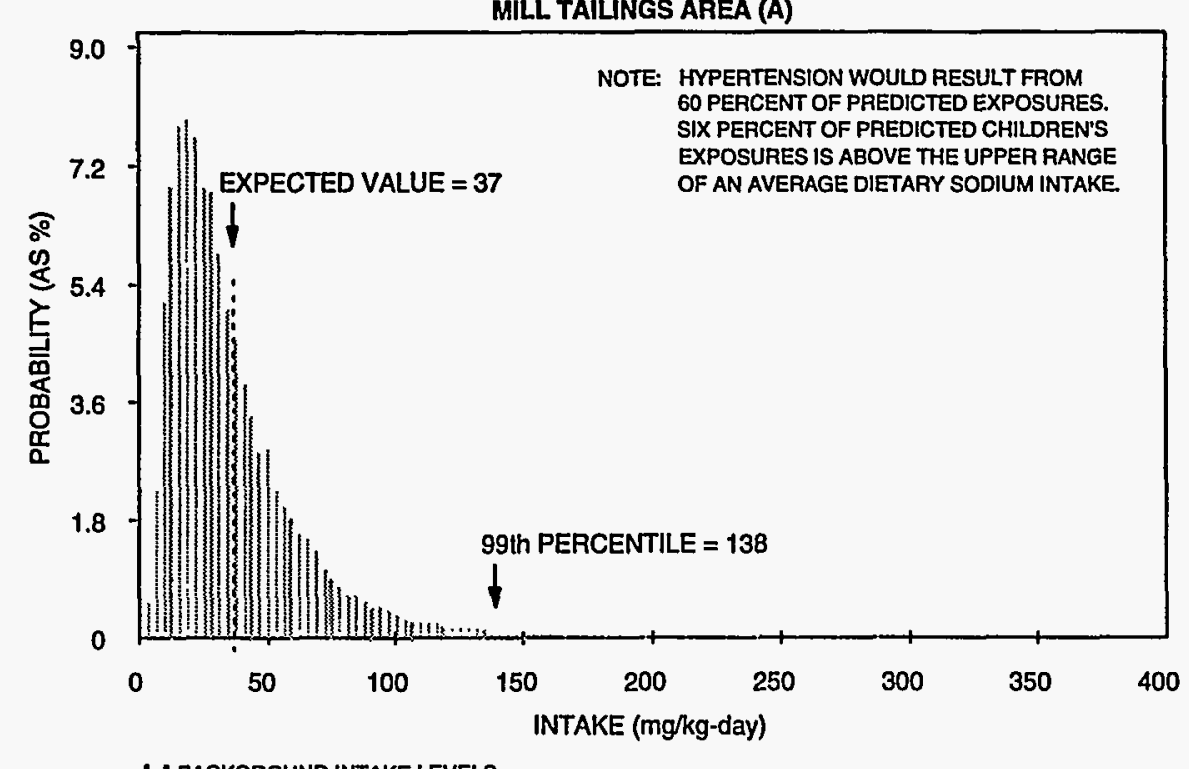

$\checkmark$ BACKGROUND INTAKE LEVELS

FROM DRINKING WATER

I NUTRITIONAL REQUIREMENT

A NRC.PECOMMENDED LIMIT FOR DIETARY INTAKE

$$
\text { ... _... DIETARY INTAKE LEVELS }
$$

$\ldots \longrightarrow$ HYPERTENSION MAY OCCUR IN HUMANS
RAFFINATE PONDS AREA (B)

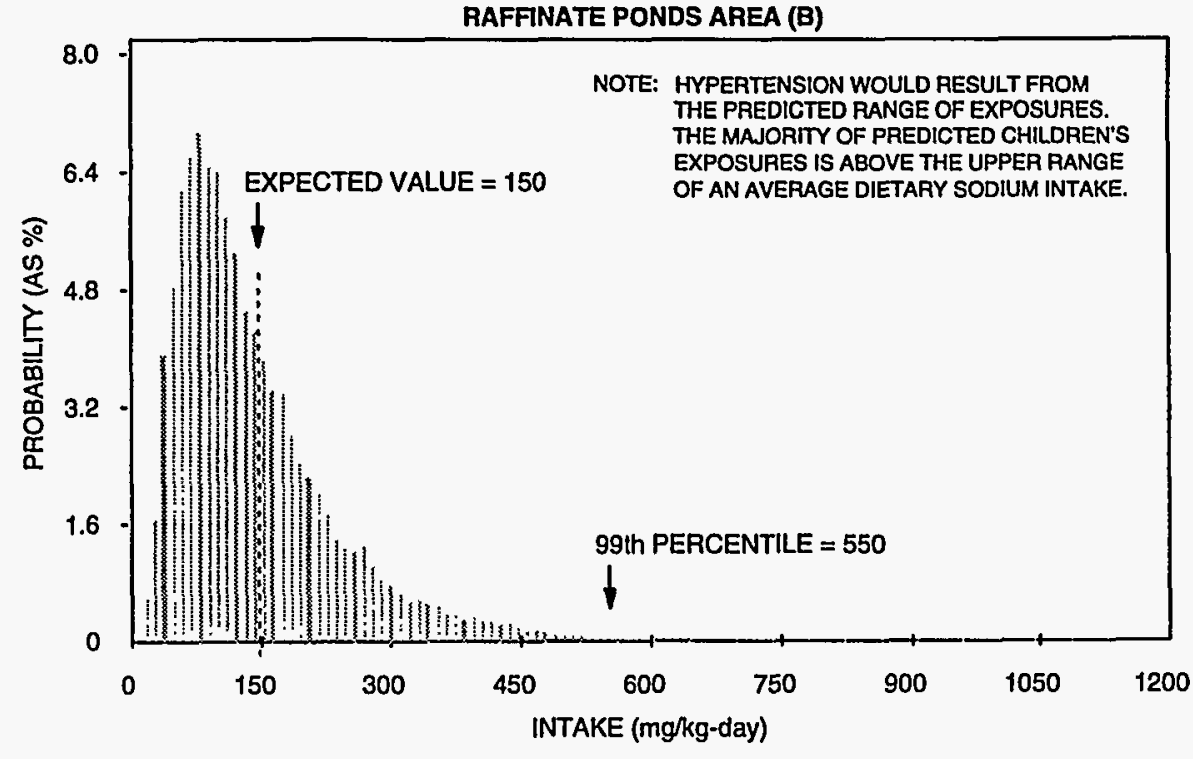

A NUTRITIONAL REQUIREMENT

I BACKGROUND INTAKE LEVELS FROM DRINKING WATER

A NRC-RECOMMENDED LIMIT FOR DIETARY INTAKE

U DIETAAY INTAKE LEVELS 


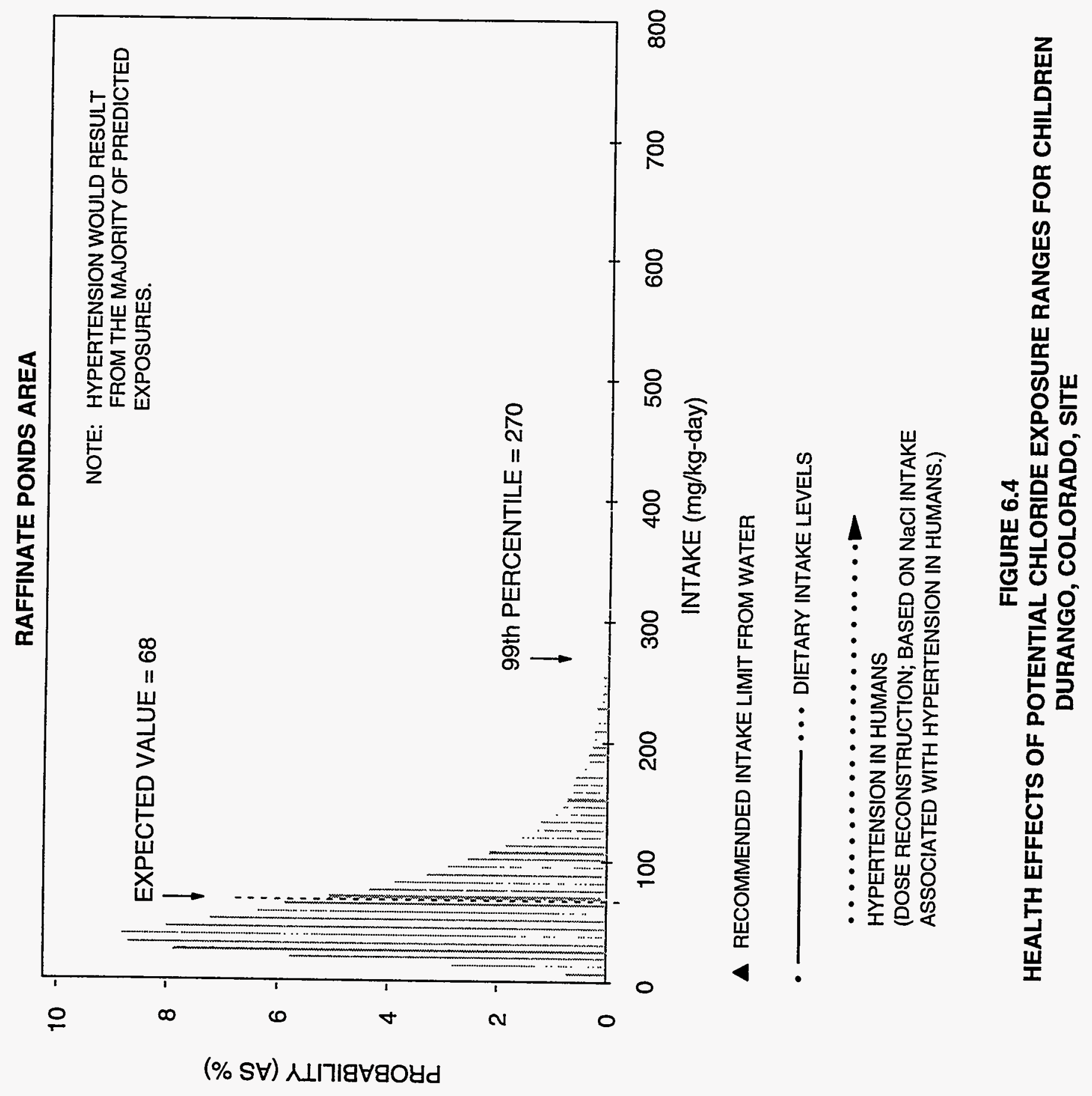




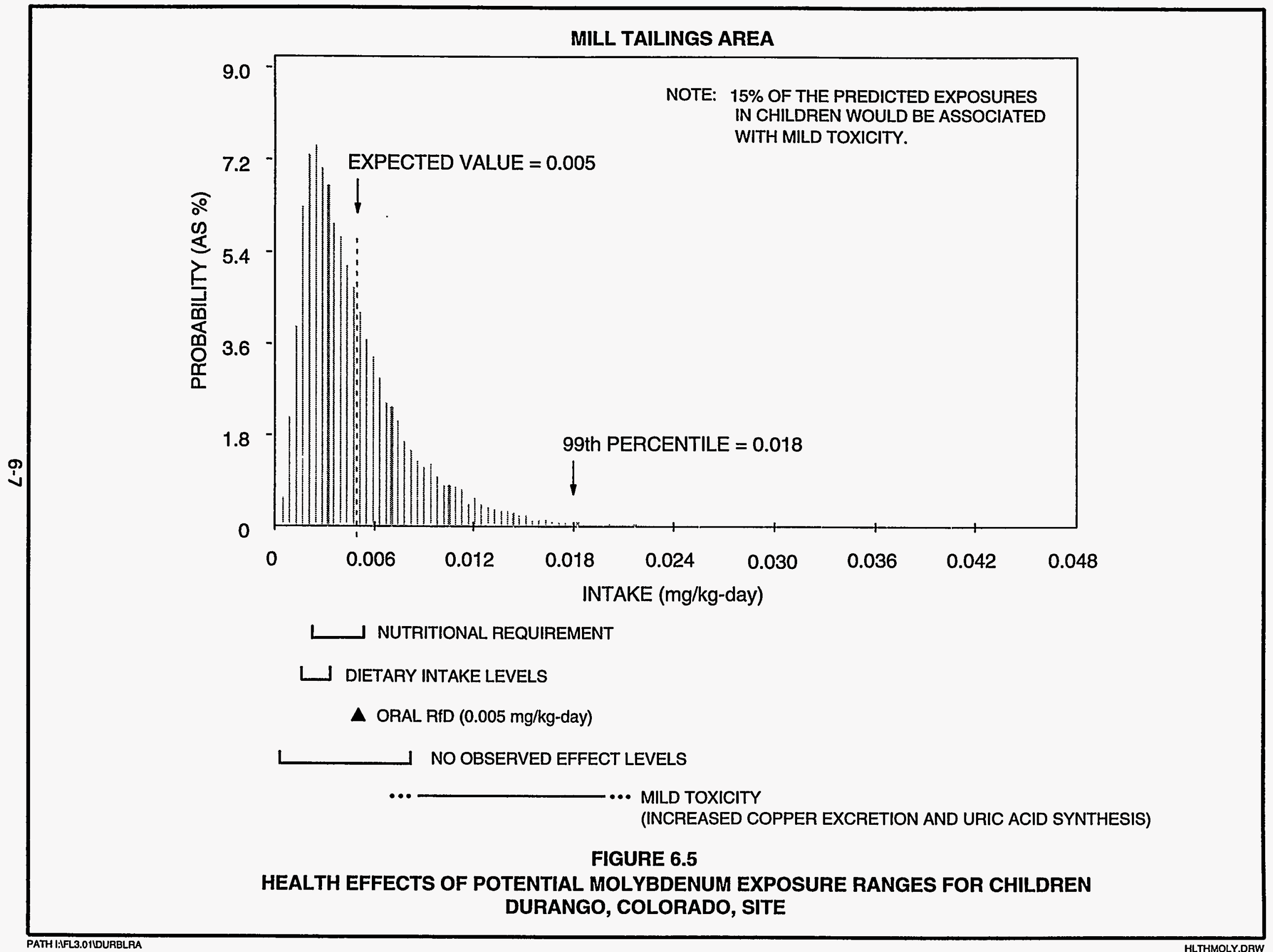




\begin{tabular}{|c|c|c|c|c|c|c|c|}
\hline \multirow[t]{5}{*}{ 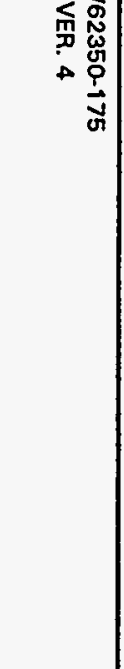 } & $\begin{array}{c}\text { Contaminant } \\
\text { of potential } \\
\text { concern }\end{array}$ & $\begin{array}{c}\text { Exposure } \\
\text { concentration } \\
(\mathrm{mg} / \mathrm{L})\end{array}$ & $\begin{array}{c}\text { Exposure } \\
\text { dose } \\
\text { (mg/kg-day) }\end{array}$ & $\begin{array}{c}\text { LOAEL }^{\mathrm{d}} \\
\text { (mg/kg-day) }\end{array}$ & $\begin{array}{l}\text { Nature of the effect } \\
\text { caused by the LOAEL }\end{array}$ & $\begin{array}{c}\mathrm{RfD}^{\boldsymbol{\theta}} \\
\text { (mg/kg-day) }\end{array}$ & $\begin{array}{c}\text { Hazard } \\
\text { quotient }\end{array}$ \\
\hline & \multicolumn{7}{|c|}{ Mill tailings area } \\
\hline & Antimony & 0.02 & $6 E-04$ & 1.8 & $\begin{array}{l}\text { Acute symptoms of gastrointestinal } \\
\text { distress }\end{array}$ & $4 \mathrm{E}-04$ & 1.5 \\
\hline & Lead & 0.04 & $1 \mathrm{E}-03$ & ND & $\begin{array}{l}\text { No safe level has been demonstrated } \\
\text { for the most sensitive effects of lead } \\
\text { exposure in humans (i.e., heme } \\
\text { synthesis, erythropoiesis, and } \\
\text { neurobehavioral toxicity) }\end{array}$ & ND & ND \\
\hline & \multicolumn{7}{|c|}{ Raffinate ponds area } \\
\hline$\theta$ & Antimony & 0.2 & $6 \mathrm{E}-03$ & 1.8 & $\begin{array}{l}\text { Acute symptoms of gastrointestinal } \\
\text { distress }\end{array}$ & $4 E-04$ & 15 \\
\hline & Arsenic & 0.2 & $6 E-03$ & 0.02 & $\begin{array}{l}\text { Cardiovascular effects manifested as } \\
\text { arterial thickening }\end{array}$ & $3 E-04$ & 20 \\
\hline & Cadmium & 0.08 & $2 \mathrm{E}-03$ & 0.0075 & $\begin{array}{l}\text { Mild kidney toxicity manifested as } \\
\text { proteinuria following long-term } \\
\text { exposure (dose estimated for a } 70 \text { - } \\
\text { kg adult) }\end{array}$ & $5 E-04$ & 4 \\
\hline & Lead & 0.07 & $2 \mathrm{E}-03$ & ND & $\begin{array}{l}\text { No safe level has been demonstrated } \\
\text { for the most sensitive effects of lead } \\
\text { exposure in humans (i.e., heme } \\
\text { synthesis, erythropoiesis, and } \\
\text { neurobehavioral toxicity) }\end{array}$ & ND & ND \\
\hline 号勇 & Molybdenum & 0.38 & $1 E-02$ & 0.008 & $\begin{array}{l}\text { Copper deficiency (dose estimated } \\
\text { for a } 70-\mathrm{kg} \text { adult) }\end{array}$ & $5 \mathrm{E}-03$ & 2 \\
\hline
\end{tabular}


Table 6.1 Calculation of hazard quotients for ingestion of ground water, Durango, Colorado, site ${ }^{\mathrm{a}}$ (Concluded)

\begin{tabular}{|c|c|c|c|c|c|c|}
\hline $\begin{array}{l}\text { Contaminant } \\
\text { of potential } \\
\text { concern }\end{array}$ & $\begin{array}{c}\text { Exposure } \\
\text { concentration } \\
\text { (mg/L) }\end{array}$ & $\begin{array}{c}\text { Exposure } \\
\text { dosec } \\
\text { (mg/kg-day) }\end{array}$ & $\begin{array}{c}\text { LOAEL } \\
\text { (mg/kg-day) }\end{array}$ & $\begin{array}{l}\text { Nature of the effect } \\
\text { caused by the LOAEL }\end{array}$ & $\begin{array}{c}\mathrm{RfD}^{\ominus} \\
\text { (mg/kg-day) } \\
\end{array}$ & $\begin{array}{l}\text { Hazard } \\
\text { quotient }\end{array}$ \\
\hline Selenium & 0.76 & $2 E-02$ & 0.013 & $\begin{array}{l}\text { Symptoms of selenosis manifested } \\
\text { as hair and nail loss in susceptible } \\
\text { individuals (estimated for a } 70-\mathrm{kg} \\
\text { adult) }\end{array}$ & $5 E-03$ & 4 \\
\hline Thallium & 0.06 & $2 E-03$ & 0.08 & $\begin{array}{l}\text { Mild toxicity manifested as } \\
\text { performance deficit in experimental } \\
\text { animals following short-term } \\
\text { exposure }\end{array}$ & $8 E-05$ & $25^{g}$ \\
\hline
\end{tabular}

a Only contaminants of potential concern not evaluated probabilistically.

${ }^{b}$ The exposure concentration is represented by the maximum observed concentration in ground water from the most contaminated wells.

${ }^{c}$ Exposure dose calculated for a 1- to 10-year-old child using equation (1) in Section 4.4, where the contaminant concentration in ground water is represented by the maximum observed concentration in the most contaminated wells; the ingestion rate $=0.7 \mathrm{~L} /$ day; the exposure frequency $=350$ days $/$ year; the exposure duration $=7$ years; body weight $=22 \mathrm{~kg}$; and the averaging time $=365$ days $\times 7$ years.

${ }^{d}$ All LOAELs are estimated for a 22-kg child, except as noted, and are based on data provided in Section 5.0.

The basis for these oral RfDs is presented in Table 5.2.

$f_{\text {Hazard quotient }}=$ exposure dose + reference dose.

gSubchronic hazard quotient for thallium would be 2.5 .

ND - Not determined. 
Eighty percent of the predicted exposure range for cadmium detected in ground water at the mill tailings area (Figure 6.6) is above the EPA-derived oral RfD; however, less than 1 percent of this exposure range may by associated with symptoms of mild kidney toxicity, including proteinuria. The cadmium intake level from ingesting contaminated ground water at the raffinate ponds area (Table 6.1) could be associated with mild kidney toxicity (Section 5.1.3). This cadmium intake is four times the EPA acceptable intake level. Diabetics and the elderly may be more sensitive to cadmium toxicity because of their already impaired kidney function. Therefore, toxic effects may appear in these sensitive individuals at lower levels than those presented in Table 6.1 and Section 5.1.3.

For selenium levels detected in ground water at the mill tailings area, approximately 85 percent of the exposure distribution falls below the acceptable intake level recommended by the EPA (RfD of $0.005 \mathrm{mg} / \mathrm{kg}$-day) and about 1 percent of the intake is above the threshold level for symptoms of mild toxicity, including nail and hair brittleness or loss (Figure 6.7). The selenium intake level at the raffinate ponds area is four times the EPA oral RfD (Table 6.1) and could also cause symptoms of mild selenosis (Section 5.1.8).

Almost the entire vanadium exposure distribution falls below any level associated with adverse health effects (Figure 6.8); however, about 80 percent of the estimated exposure range for vanadium detected in ground water from the mill tailings area is above the EPA-derived oral RfD.

The entire exposure distributions for uranium at both the mill tailings and raffinate ponds areas fall within the NOAEL (Figure 6.9A and B). However, almost 100 percent of the exposure distribution for the mill tailings area (Figure 6.9A) and 93 percent of the exposure distribution for the raffinate ponds area (Figure 6.9B) are above the EPA acceptable intake level (RfD of $0.003 \mathrm{mg} / \mathrm{kg}$-day). This apparent discrepancy occurs largely because the toxicological database is incomplete, and this uncertainty is taken into account in the acceptable intake level derived by the EPA. Though these low intake levels have not been associated with adverse health effects in humans or test animals, it is significant that most of the exposure distribution falls above this $\mathrm{RfD}$ criterion. This is because of the low level of confidence in the toxicological data.

Cadmium and uranium exposures, however, should be considered additive, because they both affect reabsorption in the proximal tubule of the kidney. This causes protein and other nutritive compounds to be excreted in the urine rather than retained by the body. The levels of uranium detected at both the mill tailings and raffinate ponds areas, however, are well below its threshold for these effects; nonetheless, the presence of both of these metals indicates a potential for additive effects and, as noted previously, diabetics and the elderly may be more sensitive to these toxic effects on the kidney.

Although the antimony exposures slightly exceed the EPA oral RfD at the mill tailings area, and antimony and thallium exceed it more than an order of 


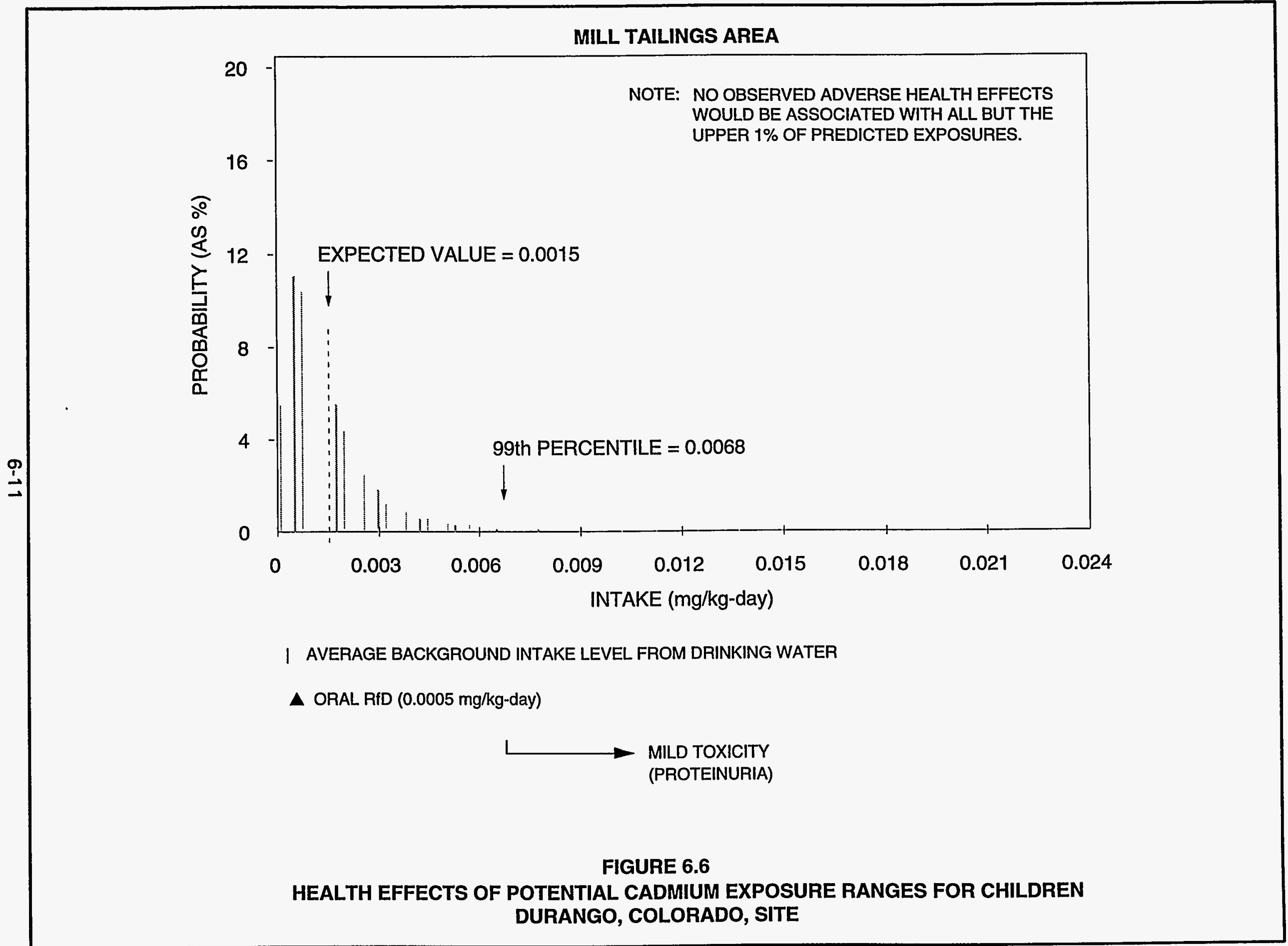




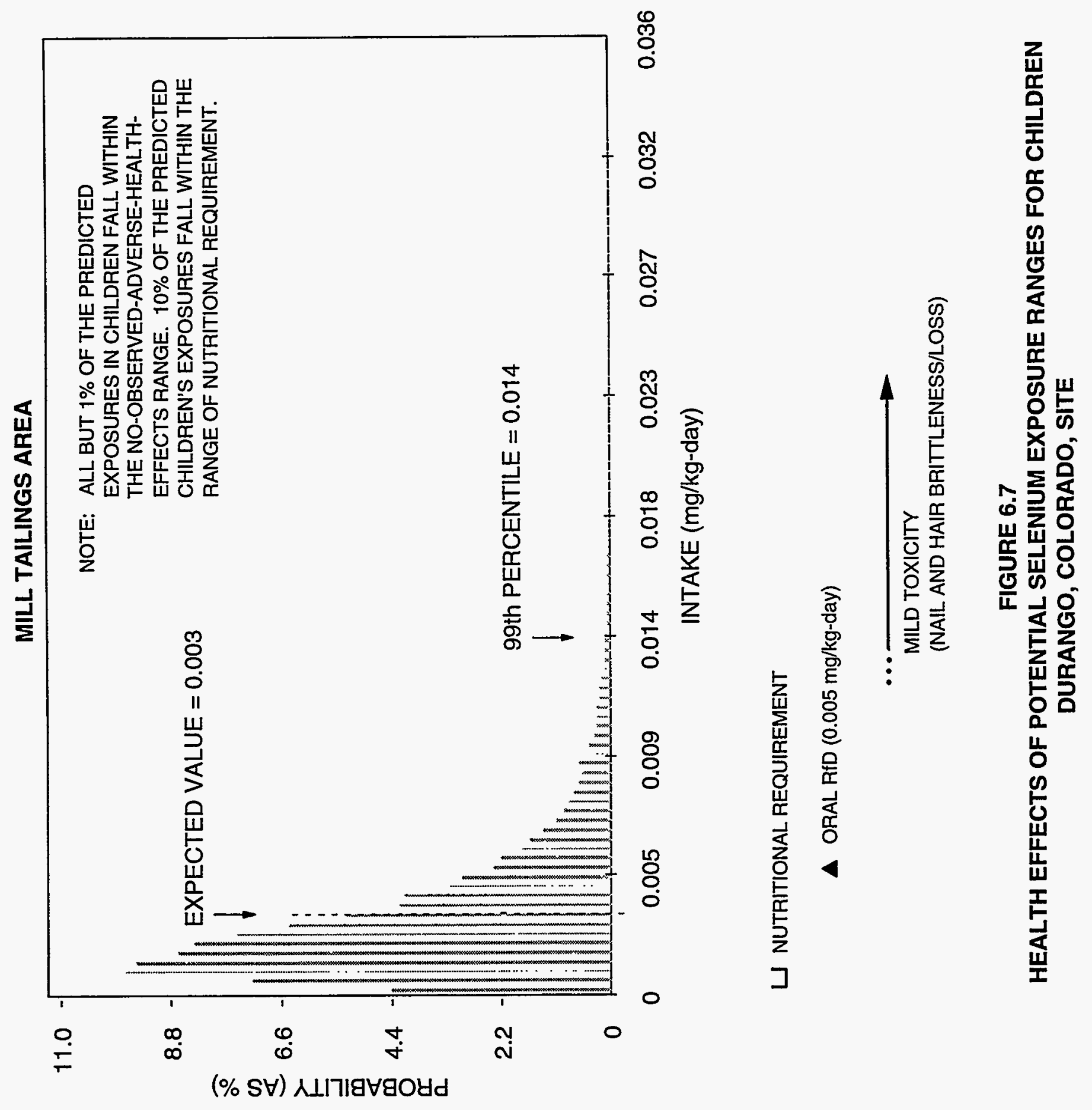



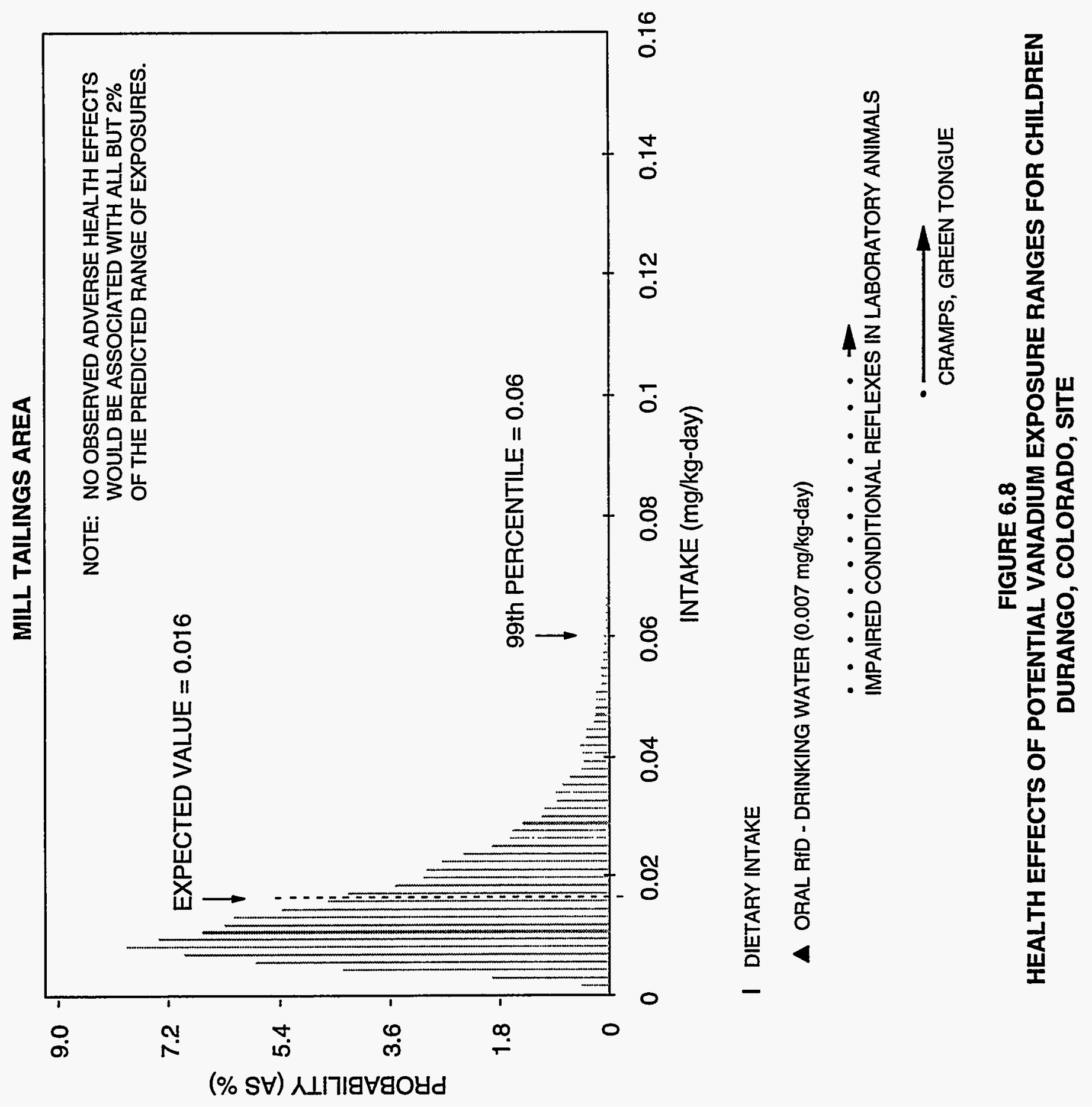
MILL TAILINGS AREA (A)

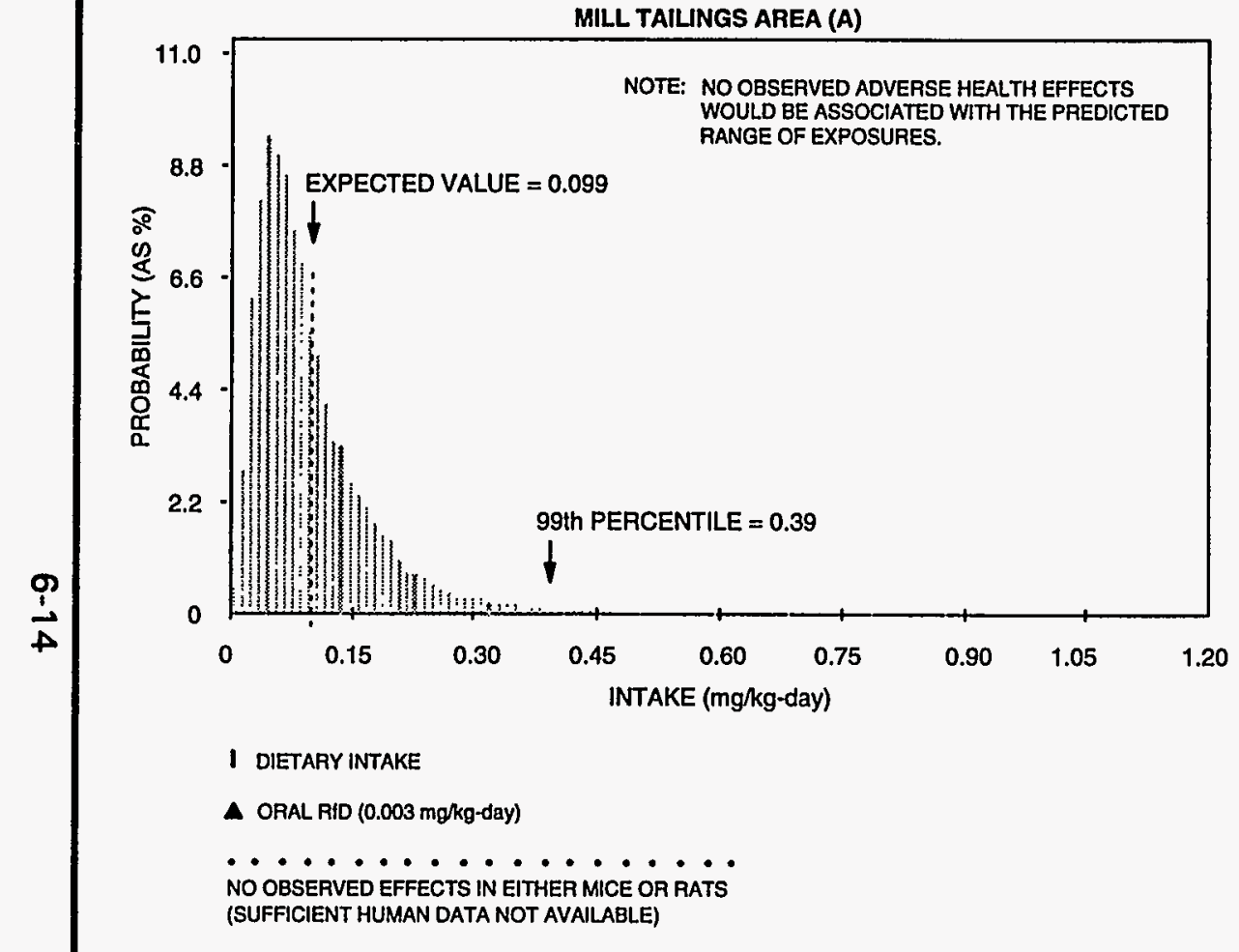

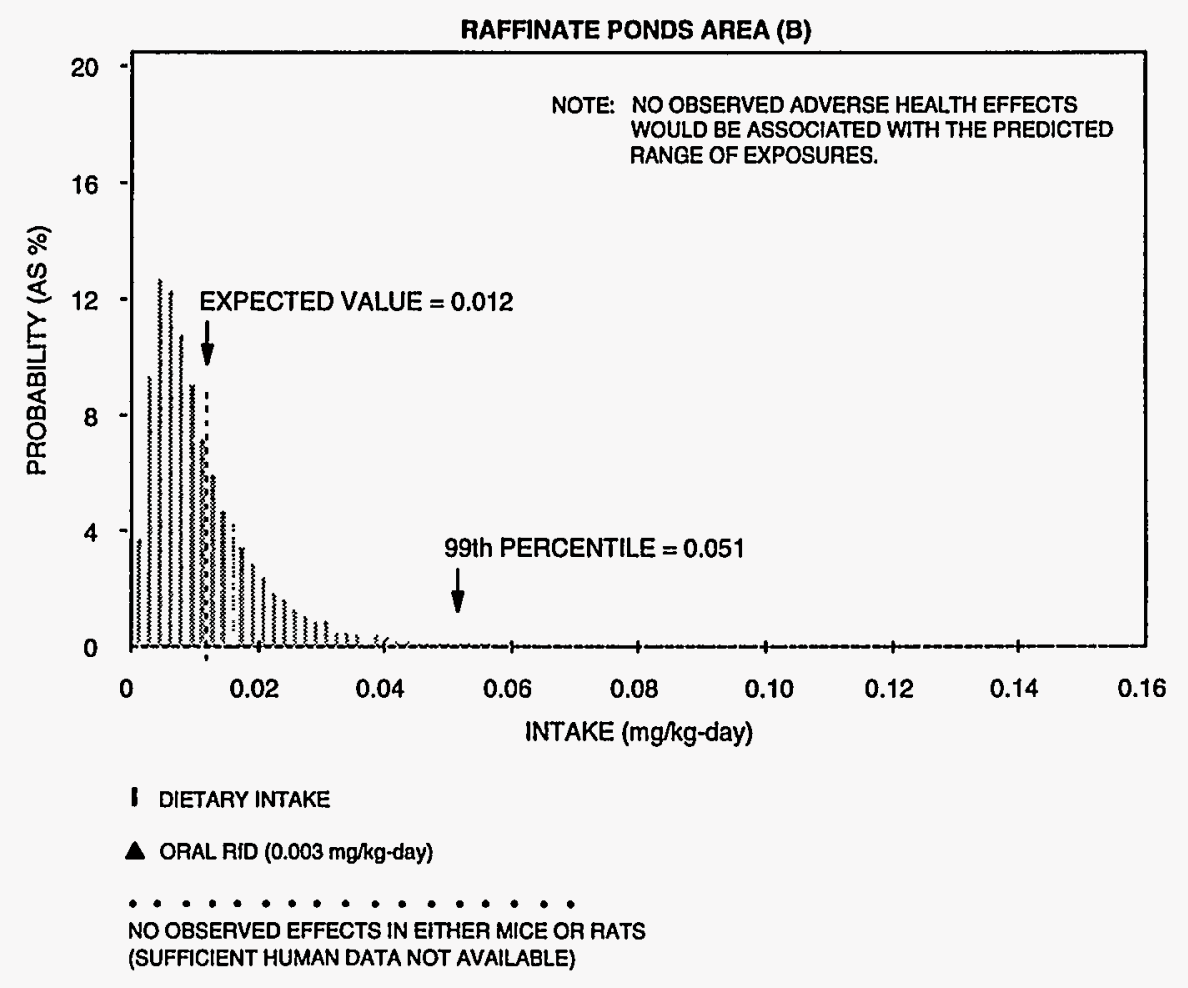

FIGURE 6.9

HEALTH EFFECTS OF POTENTIAL URANIUM EXPOSURE RANGES FOR CHILDREN DURANGO, COLORADO, SITE 
magnitude at the raffinate ponds area (Table 6.1), these intake levels fall within the dietary intake range $(0.007$ to $0.04 \mathrm{mg} / \mathrm{kg}$-day for antimony) and/or are well below any level associated with adverse health effects (Sections 5.0, 5.1.1, and 5.1.11). This apparent discrepancy occurs largely because the toxicological database is incomplete, and this uncertainty is taken into account in the acceptable intake level derived by the EPA. Though these low intake levels have not been associated with adverse health effects in humans or test animals, it is significant that most of the exposure distribution falls above this RfD criterion. This is because of the low level of confidence in the toxicological data.

Exposure levels for arsenic detected in contaminated ground water at the raffinate ponds area exceed the EPA oral RfD by roughly an order of magnitude (Table 6.1). However, no adverse health effects would be expected from this level of arsenic exposure (Section 5.1.2). In addition, arsenic and selenium together may reduce their respective toxicities; however, some methylated metabolites of selenium can increase arsenic toxicity.

If contaminated ground water from either the mill tailings area or the raffinate ponds area were used as drinking water, the levels of potential exposure to lead detected (Table 6.1) could be associated with some of the adverse health effects of lead, particularly hematological changes and changes in children's neurobehavioral development (Section 5.1.5). These changes may occur at intake levels as low as to be essentially without threshold. For this reason, the EPA considers it inappropriate to develop an oral RfD for inorganic lead.

Finally, diarrhea-induced dehydration may lead to increased concentration of contaminants in the kidney, enhancing the predicted toxicity from sodium and nephrotoxic metals.

The potential exposure contribution from other pathways, including produce ingestion or meat ingestion, could not be estimated with current data. The UMTRA Project is conducting additional studies, and the results will be used to better characterize these pathways. Although drinking water ingestion is assumed to result in the greatest exposure, these pathways may contribute significantly to overall exposure. Additionally, these pathways are of interest because plant uptake and food chain transfer can occur under current site conditions (i.e., without installation of a well).

Another pathway considered feasible for this site is fish ingestion. Again, there are not sufficient data to evaluate this pathway or even to determine whether fish are concentrating site-related contaminants. However, based on fish analyses obtained by the BOR for fish $8 \mathrm{mi}(13 \mathrm{~km})$ upstream and downstream from the site, fish ingestion may cause an increased dietary intake of certain elements that could make people who eat fish toxicologically sensitive to additional exposures (i.e., ground water ingestion). Of the contaminants of potential concern for the site, intakes of antimony, arsenic, cadmium, lead, manganese, and selenium from fish ingestion could increase estimated 
background dietary ranges and consequently increase risks described here for ground water ingestion or other pathways not evaluated.

\subsection{POTENTIAL CARCINOGENIC HEALTH EFFECTS}

All uranium isotopes are radioactive and, as such, are considered potential carcinogens. Table 6.2 shows estimated excess lifetime cancer risks resulting from potential ingestion of ground water contaminated with uranium-234/238 and longer-lived radioactive progeny of the uranium decay series llead-210, radium-226, polonium-210, and thorium-230) at the mill tailings and raffinate ponds areas. These estimates are based on the cancer SFs developed by the EPA; however, natural uranium has not been demonstrated to cause cancer in humans or animals following ingestion exposures. The potential exposure values result in an excess lifetime cancer risk of about 1 in 1000 for the mill tailings area and 2 in 10,000 for the raffinate ponds area. These exceed the EPA's National Contingency Plan (NCP) guidance (developed for Superfund sites) of a maximum increased cancer risk of 1 in 10,000 .

If contaminated ground water at the raffinate ponds area were used as drinking water, the risk of skin cancer could increase as a result of chronic exposure to detected arsenic levels (Table 6.2). This evaluation is based on the EPA oral SF of $1.8\left(\mathrm{mg} / \mathrm{kg}\right.$-day) ${ }^{-1}$ for skin cancer development. The estimated arsenic exposure value could result in an excess lifetime cancer risk of about 4 in 1000 and could exceed the NCP guidance.

The cancer risk estimates presented here are thought to be conservative because they are based on a cumulative 30-year exposure duration. As previously discussed, this exposure duration is probably appropriate; however, ground water concentrations may decline over this time because the site has been cleaned up.

\subsection{LIMITATIONS OF RISK EVALUATION}

The following potential limitations should be kept in mind when interpreting this risk evaluation.

- This risk assessment evaluates only risks related to ground water contaminated with inorganics. Any potential contamination with organic constituents has not been addressed.

- Populations with potentially increased sensitivity, such as the elderly or individuals with preexisting diseases, were not specifically addressed on the toxicity ranges presented on the graphs. Expected sensitivities in certain groups were discussed in the text to the extent possible.

- Some individuals may be more sensitive to the toxic effects of certain constituents for reasons that have not been determined. Therefore, adverse health effects may occur at lower exposure levels in sensitive individuals. 


\begin{tabular}{|c|c|c|c|c|}
\hline $\begin{array}{c}\text { Contaminant of potential } \\
\text { concern }\end{array}$ & $\begin{array}{c}\text { Exposure concentration } \\
(\mathrm{pCi} / \mathrm{L})\end{array}$ & $\begin{array}{c}\text { Exposure dose } \\
\text { (mg/kg-day; pCi/lifetime) }\end{array}$ & $\begin{array}{c}\text { Oral SF} \\
(\mathrm{mg} / \mathrm{kg}-\mathrm{day})^{-1} ;(\mathrm{pCi})^{-1}\end{array}$ & Cancer risk $^{\mathbf{d}}$ \\
\hline \multicolumn{5}{|l|}{ Mill tailings area } \\
\hline \multicolumn{5}{|l|}{ Radionuclides } \\
\hline Lead-210 & 4.4 & $9.2 E+04$ & $6.6 E-10$ & $6 \mathrm{E}-05$ \\
\hline Polonium-210 & 0.2 & $4.2 E+03$ & $1.5 \mathrm{E}-10$ & $6 \mathrm{E}-07$ \\
\hline Radium-226 & 1.2 & $2.5 E+04$ & $1.2 \mathrm{E}-10$ & 3E-06 \\
\hline Thorium-230 & 1.8 & $3.8 \mathrm{E}+04$ & 1.3E-11 & $5 E-07$ \\
\hline Uranium-234 & 1300 & $2.7 E+07$ & $1.6 \mathrm{E}-11$ & $4 \mathrm{E}-04$ \\
\hline Uranium-238 & 1300 & $2.7 E+07$ & $2.0 \mathrm{E}-11$ & $5 \mathrm{E}-04$ \\
\hline TOTAL: & & & & $1 \mathrm{E}-03$ \\
\hline \multicolumn{5}{|l|}{$\begin{array}{l}\text { Raffinate ponds area } \\
\text { Chemicals }\end{array}$} \\
\hline Arsenic & $0.2^{\mathrm{e}}$ & $2.3 \mathrm{E}-03$ & $1.8 E+00$ & $4 \mathrm{E}-03$ \\
\hline \multicolumn{5}{|l|}{ Radionuclides } \\
\hline Lead-210 & 2.1 & $4.4 E+04$ & $6.6 \mathrm{E}-10$ & $3 E-05$ \\
\hline Polonium-210 & 0.1 & $2.1 E+03$ & $1.5 E-10$ & $3 E-07$ \\
\hline Radium-226 & 0.8 & $1.7 E+04$ & $1.2 \mathrm{E}-10$ & $2 E-06$ \\
\hline Thorium-230 & 4.5 & $9.4 E+04$ & $1.3 \mathrm{E}-11$ & $1 \mathrm{E}-06$ \\
\hline Uranium-234 & 195 & $4.1 E+06$ & $1.6 \mathrm{E}-11$ & 7E-05 \\
\hline Uranium-238 & 195 & $4.1 E+06$ & 2.0E-11 & $8 E-05$ \\
\hline TOTAL: & & & & $2 \mathrm{E}-04$ \\
\hline \multicolumn{5}{|c|}{$\begin{array}{l}{ }^{a} \text { The exposure concentration is represented by the maximum observed concentration in unfiltered ground water samples from the most } \\
\text { contaminated wells. } \\
\text { bCalculated using equations (2) and ( } 3 \text { ) in Section } 4.4 \text { for arsenic and radionuclides, respectively, and the following exposure } \\
\text { assumptions: contaminant concentrations in ground water are represented by the maximum observed concentration in ground water } \\
\text { from the most contaminated wells; the ingestion rate }=2 \mathrm{~L} \text { of water/day; the exposure frequency }=350 \text { days/year; the exposure } \\
\text { duration }=30 \text { years; body weight }=70 \mathrm{~kg} \text {. } \\
\text { c The basis for these oral SFs is presented in Table } 5.1 \text {. } \\
\text { dCarcinogenic risk = exposure dose X SF. } \\
\text { e Units are milligrams per liter. }\end{array}$} \\
\hline
\end{tabular}


- Available data on potential adverse health effects may not always be sufficient to accurately determine all health effects because human data are not sufficient or exposure ranges differed from exposures expected at this site.

- Although contaminated ground water movement has been evaluated hydrologically and geochemically, it is possible that the monitoring locations sampled were not in the most contaminated portion of the ground water. Additionally, concentrations may increase or decrease substantially as the contaminated ground water moves.

- The risk evaluation results presented in this document are largely based on filtered $(0.45-\mu \mathrm{m})$ ground water samples. Therefore, the potential loss of certain ground water constituents as a consequence of filtration is associated with a source of uncertainty.

- Only the drinking water ingestion pathway was considered in depth, and the dermal absorption pathway was screened out. However, the incremental contribution from the ground water-irrigated produce and meat ingestion pathways, which could not be estimated here, could be significant. Therefore, the additivity of exposure from other pathways or from increased regional background levels or dietary intakes (e.g., from fish ingestion) should be considered.

The evaluation presented here has considered these limitations and compensated wherever possible by presenting toxicity ranges and probabilistic exposure assessments rather than point estimates to incorporate as much variability as could be reasonably defined. The impact of these potential limitations is discussed more fully in Section 8.2. 


\subsection{ECOLOGICAL RISK EVALUATION}

This section assesses the potential for site-related contaminants to adversely affect the existing biological communities or agricultural practices in the area. Currently, the EPA has no guidance for quantifying ecological impacts of the release of hazardous constituents; however, the EPA has developed a qualitative approach to be used in ecological risk evaluations (EPA, 1989b). As part of this qualitative approach, the EPA recommends that ecological assessments be conducted in a phased approach, because it ensures the most effective use of resources while resulting in all necessary work being conducted (EPA, $1992 \mathrm{~b})$. This approach consists of four phases:

- Identification of potentially exposed habitats.

- Collection and analysis of site chemistry data.

- Collection and analysis of biological samples.

- Toxicity testing.

If the initial inspection of the habitats or the analysis of media samples indicates that there is no or very low potential for an ecological risk, the assessment may be complete. If the early phases of the assessment indicate that the contaminants may be adversely affecting ecological receptors, a higher level of analysis may be warranted. This ecological risk assessment of the Durango site consists of the first two phases: identification of habitats and collection of site chemistry data.

It is often difficult to determine whether contaminants have affected the biological component of an ecosystem and to predict whether observed effects will damage the ecosystem. However, the sampling of environmental media can be used to assess the possibility of an ecological risk occurring. For such a risk to occur, a source of contamination must exist and there must be pathway for this contamination to reach the biological communities. The following sections identify 1) the areas of contamination and the potential pathways by which this contamination may be entering the aquatic and terrestrial ecosystems at the Durango site, 2) the potential ecological receptors at the site, 3) the contaminants of potential concern, and 4) the potential hazards the contaminants of potential concern may pose to the ecological or agricultural resources.

\subsection{EXPOSURE CHARACTERIZATION}

This section characterizes the probable and possible pathways through which ecological receptors are likely to be exposed to site-related contaminants. Exposure can occur only if there are both a source of contamination and a mechanism of transport to a receptor population.

Between 1986 and 1991, the tailings piles and soils contaminated from uranium milling operations (mill tailings area) and raffinate (raffinate ponds area) were relocated to a disposal cell. The former mill tailings area and raffinate ponds area were then contoured and planted with grasses. Thus, soil or air exposure pathways (such as incidental soil ingestion, dermal contact with soil, and inhalation of particulates) will not be evaluated. 
Ground water, surface water, and sediment are the potentially affected environmental media at the site. Direct and indirect exposure of ecological receptors to these media may occur by various surface- and ground waterrelated exposure pathways (such as ingestion of surface water, ingestion of sediment or ground water, bioconcentration of contaminants from surface water or sediment by aquatic organisms, and consumption of plants and other organisms that have accumulated contaminants).

The Durango site is bordered by Lightner Creek to the north, an ephemeral stream (South Creek) to the south, and the Animas River to the east. Lightner Creek does not likely receive contaminated ground water from the site, although it was used historically to discharge wastes. Because South Creek does not appear to be hydrologically connected to contaminated ground water at the site, it is not evaluated in this risk assessment.

Ground water at the mill tailings area moves predominantly through the alluvium overlying the low-permeability Mancos Shale bedrock and discharges to the Animas River to the east. Ground water moving beneath the raffinate ponds area also discharges to the Animas River. Resident aquatic life and terrestrial wildlife may come in contact with surface water and sediments in these water bodies. Although the site contaminants appear to have a negligible impact on surface water quality in the Animas River, the surface water, in addition to sediment pathways, is evaluated to determine risks to aquatic and terrestrial life.

Terrestrial vegetation may take up contaminants from ground water. Due to the presence of shallow alluvial ground water at both the raffinate ponds area and the mill tailings area, plant roots may reach soil saturated with contaminated ground water. As such, plant uptake is considered in this risk assessment.

Other potential pathways involve the use of surface water mixed with ground water as a source of water for livestock or other agricultural activities. The BOR has plans to construct the Durango pumping plant, a feature of the Animas-La Plata Project, on the former raffinate ponds area of the Durango site. The Animas-La Plata Project would furnish water for municipal and industrial use and for irrigation for southwest Colorado and northwest New Mexico. The plant would pump water directly from the Animas River. Because of uncertainties associated with this construction project, pathways related to this project are not evaluated in this risk assessment.

\subsection{ECOLOGICAL RECEPTORS}

This section identifies the ecological resources present at the site and in its vicinity that may be potentially exposed to site-related contaminants. The following information on ecological receptors is based primarily on surveys performed prior to removal activities (DOE, 1985; Dames \& Moore, 1983) and on surveys performed as part of the Animas-La Plata Project (BOR, 1980). 
Limited observations of aquatic organisms were conducted at surface water and sediment sampling locations during November 1993 sampling activities. Limited observations of terrestrial flora and fauna were also conducted during the November 1993 field sampling and during a ground water use/field survey in June 1994.

\subsubsection{Terrestrial resources}

Most of the land within the site boundary has been disturbed by milling operations and subsequently during tailings/contaminated soil removal, which included excavation to the bedrock in places.

\section{Flora}

Vegetation at the Durango site was characterized prior to removal activities (DOE, 1985; Dames \& Moore, 1983). At that time, the site was highly disturbed and contained limited vegetative cover and habitat. Patches of smooth brome occurred across the site as part of revegetation efforts. Alfalfa and Kentucky bluegrass were minor constituents of this vegetation. Riparian scrub, present along the Animas River adjacent to the site, was composed primarily of narrowleaf cottonwood and boxelder with thickets of willow and river alder common in the understory. Vegetation found on the upper slopes of Smelter Mountain adjacent to the processing site consisted of Utah juniper, boxelder, Gambel oak, skunk bush, and Oregon grape. Rubber rabbitbrush and big sagebrush were predominant on the lower, gentler slopes of Smelter Mountain.

Upon completion of removal activities, both the mill tailings area and the raffinate ponds area were contoured and seeded with grasses. These grasses included smooth brome, Kentucky bluegrass, western wheatgrass, blue grama, gallets, and saltgrass. Along the site side of the river, riparian habitat is predominantly an open field or rocky shoreline with scattered small willow, boxelder, and cottonwood. Near the city park and sewage treatment plant across from the site, open woods are present, including large boxelders, cottonwoods, and willows. Thickets of cottonwood and willow mixed with grasses are present along the river, opposite the raffinate ponds area.

\section{Fauna}

Wildlife is limited at this site because of its disturbed nature and its proximity to roads and highways. Wintering bald eagles occur along the Animas River, and mule deer cross the area while using adjacent upland habitat and the Animas River. Various small mammals and birds were observed on the site prior to removal activities, including cottontail rabbits, deer mice, black-billed magpie, northern flicker, barn swallow, American robin, red-winged blackbird, and Brewer's blackbird. Signs of mule deer and cottontail were found on the Durango site during the June 1994 survey. Numerous barn swallows, redwinged blackbirds, robins, and Brewer's blackbirds were also seen at this time. 
A garter snake was observed along the banks of the Animas River, and trees gnawed by beaver were observed along the river near the mill tailings area, although no beaver colonies were seen.

\subsubsection{Aquatic organisms}

No quantitative survey of aquatic organisms has been conducted to date. A brief qualitative survey was performed during the November 1993 field sampling.

The Animas River from the mouth of Junction Creek to the Colorado-New Mexico state line has been classified by the state of Colorado for class 1 cold water aquatic life uses. Previous investigations in the site vicinity (DOE, 1985; BOR, 1980) indicate that the only significant trout fishery in the Animas River, consisting of rainbow trout, cutthroat trout, and brown trout, occurs within the city limits of Durango and approximately $5 \mathrm{mi}(8 \mathrm{~km})$ downstream. This fishery results from an intensive stocking program by the Colorado Division of Wildlife. The quality of the Animas River sport fishery approximately $10 \mathrm{mi}(16 \mathrm{~km})$ downstream degrades considerably because of siltation, high summer water temperatures, and low summer velocities. Fish species in this lower reach include bluehead sucker, flannelmouth sucker, carp, and occasional brown trout. Other species identified in the Animas River in Colorado include cutthroat trout and mottled sculpin (BOR, 1980).

\subsubsection{Threatened and endangered species}

The following information on threatened and endangered species in the vicinity of the Durango site was adapted from the environmental impact statement (DOE, 1985) and the Animas-La Plata Project draft environmental impact statement (BOR, 1980). Further information on threatened and endangered species can be found in these documents.

Several plant and animal species listed or proposed for listing by the U.S. Fish and Wildlife Service as endangered and threatened occur or could occur in the Durango area. They include the peregrine falcon, bald eagle, ferruginous hawk, Swainson's hawk, spotted bat, spineless hedgehog cactus, and Mesa Verde cactus.

There are some historical bald eagle nest sites in the Durango area, but they are not known to be used. Bald eagles commonly winter in the Durango area. Potential nesting habitat for the peregrine falcon exists within $1 \mathrm{mi}(1.6 \mathrm{~km})$ of the Bodo Canyon disposal site. 


\subsection{CONTAMINANTS OF ECOLOGICAL CONCERN}

\subsubsection{Ground water}

Ground water occurs in a shallow alluvial aquifer overlying bedrock at the mill tailings site. At the raffinate ponds area, ground water occurs in the alluvium and in the underlying Menefee/Point Lookout Formation.

All chemicals detected above background levels, or above method detection limits where background data were not available, were considered to be contaminants of potential concern in ground water. For the raffinate ponds area, DOE monitor well DUR-02-602 was selected to represent the center of the plume; for the mill tailings area, DOE monitor well DUR-01-612 was selected to represent the center of the plume.

The exposure concentration used for ground water was the maximum detected concentration within each well from sampling dates in April 1988 through November 1993. Both filtered and nonfiltered concentrations measured in these wells are used.

\subsubsection{Surface water and sediment}

Surface water and sediment sampling locations are shown in Figure 3.1. Surface water and sediment samples were collected in November 1993 from the Animas River upstream of the confluence of the river and Lightner Creek and downstream of Colorado Route 160 (location 652). Surface water and sediment samples were collected from Lightner Creek upstream of the Durango site near Cottonwood Campground (location 650).

The list of contaminants of potential concern in the surface water bodies adjacent to this site was developed from the same list of contaminants evaluated for ground water. It is assumed that site-related contaminants in the Animas River water may occur as a result of ground water discharge. Therefore, site-related contaminants were modeled to estimate the contribution of ground water contaminant flow into the Animas River. This model (Tables 3.18 and 3.19 ) shows that ground water constitutes a small proportion of flow in the river (less than 0.4 percent during low flow); therefore, contaminants are quickly diluted. The modeled increment is added to the upstream surface water concentrations. This sum and the observed downstream concentrations are compared with available water quality criteria (Tables 7.1 and 7.2). Based on these comparisons, there are no contaminants of potential concern in surface water, because modeled values do not exceed available water quality criteria. While the site contributions are far smaller than the available water quality criteria, in three cases (cadmium, iron, and zinc), observed maximum downstream values exceed the criteria. These exceedances are less than two times their corresponding upstream measurements. However, the data are not sufficient to determine whether the differences in upstream and downstream concentrations are statistically significant. Unlike the modeled values, the levels 


\begin{tabular}{|c|c|c|c|c|c|c|}
\hline \multirow{3}{*}{ 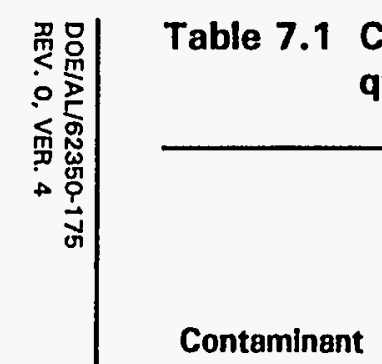 } & \multicolumn{6}{|c|}{$\begin{array}{l}\text { Comparison of measured concentrations of contaminants of potential concern and modeled surface water } \\
\text { quality in the Animas River near the mill tailings area with water quality criteriaa }\end{array}$} \\
\hline & \multicolumn{4}{|c|}{ Surface water concentration } & \multirow[b]{2}{*}{$\begin{array}{c}\text { CDPHE water } \\
\text { quality criteria } \\
\text { (filtered) }\end{array}$} & \multirow{2}{*}{$\begin{array}{l}\text { CWA freshwater } \\
\text { toxicity criteria } \\
\text { (chronic) } \\
\text { (unfiltered) }\end{array}$} \\
\hline & $\begin{array}{l}\text { Average upstream } \\
\text { (maximum unfiltered) }\end{array}$ & $\begin{array}{c}\text { Modeled downstream } \\
\text { (greatest hydraulic } \\
\text { conductivity) }\end{array}$ & $\begin{array}{l}\text { Modeled downstream } \\
\text { (average hydraulic } \\
\text { conductivity) }\end{array}$ & $\begin{array}{c}\text { Measured average } \\
\text { downstream } \\
\text { (maximum unfiltered) }\end{array}$ & & \\
\hline Ammonium & NA & NR & NR & NA & 0.02 & NS \\
\hline Antimony & NA & NR & NR & NA & NS & 0.030 \\
\hline Barium & NA & NR & NR & NA & NS & NS \\
\hline Cadmium & $\begin{array}{c}0.0002 \\
10.00091\end{array}$ & 0.0004 & 0.0002 & $\begin{array}{c}0.0002 \\
(0.0016)\end{array}$ & $0.003^{b}$ & 0.0011 \\
\hline Calcium & 61 & 62 & 61 & 72 & NS & NS \\
\hline Chloride & 11 & 13 & 11 & 12 & NS & 230 \\
\hline Fluoride & 0.3 & 0.3 & 0.3 & 0.3 & NS & NS \\
\hline Lead & $\begin{array}{l}0.001 \\
(0.08)\end{array}$ & 0.001 & 0.001 & $\begin{array}{c}0.001 \\
(0.026)\end{array}$ & $0.018^{b}$ & 0.0032 \\
\hline Magnesium & 10 & 11 & 10 & 23 & NS & NS \\
\hline Manganese & $\begin{array}{c}0.06 \\
10.331\end{array}$ & 0.08 & 0.06 & $\begin{array}{l}0.07 \\
10.371\end{array}$ & 1 & NS \\
\hline Molybdenum & $<0.01$ & $<0.011$ & $<0.01$ & NA & 0.79 & NS \\
\hline Nitrate & 0.5 & 0.6 & 0.5 & 1.2 & NS & $90^{c}$ \\
\hline Selenium & $\begin{array}{l}<0.002 \\
(0.034)\end{array}$ & $<0.0024$ & $<0.002$ & $\begin{array}{c}<0.002 \\
(0.028)\end{array}$ & 0.017 & 0.005 \\
\hline Silica & NA & NR & NR & NA & NS & NS \\
\hline Silver & $<0.0002$ & $<0.00023$ & $<0.0002$ & $\begin{array}{c}<0.0002 \\
(0.0005)\end{array}$ & $0.002^{b}$ & 0.00012 \\
\hline Sodium & 13 & 16 & 13 & 20 & NS & NS \\
\hline Strontium & NA & NR & NR & NA & NS & NS \\
\hline Sulfate & 113 & 121 & 114 & 111 & NS & NS \\
\hline 总产 & NA & NR & NR & NA & NS & NS \\
\hline
\end{tabular}


Table 7.1 Comparison of measured concentrations of contaminants of potential concern and modeled surface water quality in the Animas River near the mill tailings area with water quality criteria ${ }^{a}$ (Concluded)

\begin{tabular}{|c|c|c|c|c|c|c|}
\hline \multirow[b]{2}{*}{ Contaminant } & \multicolumn{4}{|c|}{ Surface water concentration } & \multirow[b]{2}{*}{$\begin{array}{l}\text { CDPHE water } \\
\text { quality criteria } \\
\text { (filtered) }\end{array}$} & \multirow[b]{2}{*}{$\begin{array}{l}\text { CWA freshwater } \\
\text { toxicity criteria } \\
\text { (chronic) } \\
\text { (unfiltered) }\end{array}$} \\
\hline & $\begin{array}{l}\text { Average upstream } \\
\text { (maximum unfiltered) }\end{array}$ & $\begin{array}{c}\text { Modeled downstream } \\
\text { (greatest hydraulic } \\
\text { conductivity) }\end{array}$ & $\begin{array}{l}\text { Modeled downstream } \\
\text { (average hydraulic } \\
\text { conductivity) }\end{array}$ & $\begin{array}{l}\text { Measured average } \\
\text { downstream } \\
\text { (maximum unfiltered) }\end{array}$ & & \\
\hline Uranium & $\begin{array}{l}<0.005 \\
1<0.005 \mid\end{array}$ & 0.01 & $<0.006$ & $\begin{array}{c}\text { NA } \\
(<0.005)\end{array}$ & $5^{b}$ & NS \\
\hline Vanadium & NA & NR & NR & NA & NS & NS \\
\hline Zinc & $\begin{array}{c}0.014 \\
(0.24) \\
\end{array}$ & 0.022 & 0.015 & $\begin{array}{l}0.004 \\
(0.28)\end{array}$ & $0.047^{b}$ & 0.11 \\
\hline
\end{tabular}

${ }^{\mathrm{a}}$ Maximum ground water concentrations are for both filtered and unfiltered samples. Average surface water concentrations are for filtered

samples. All data in milligrams per liter.

bWater hardness-related state standard (CDPHE, 1991) calculated using a contaminant-specific equation and the average hardness determined

from the concentrations observed in filtered samples of calcium and magnesium $(300 \mathrm{mg} / \mathrm{L})$.

'No state or federal criteria are available. The value presented is the concentration at or below which no adverse effects are expected for warmwater fish (EPA, 1986).

CDPHE - Colorado Department of Public Health and Environment; formerly the Colorado Department of Health (CDH). This document refers to the department as the "CDPHE" throughout.

CWA - Clean Water Act.

NA - not analyzed.

NR - not relevant.

NS - not specified. 


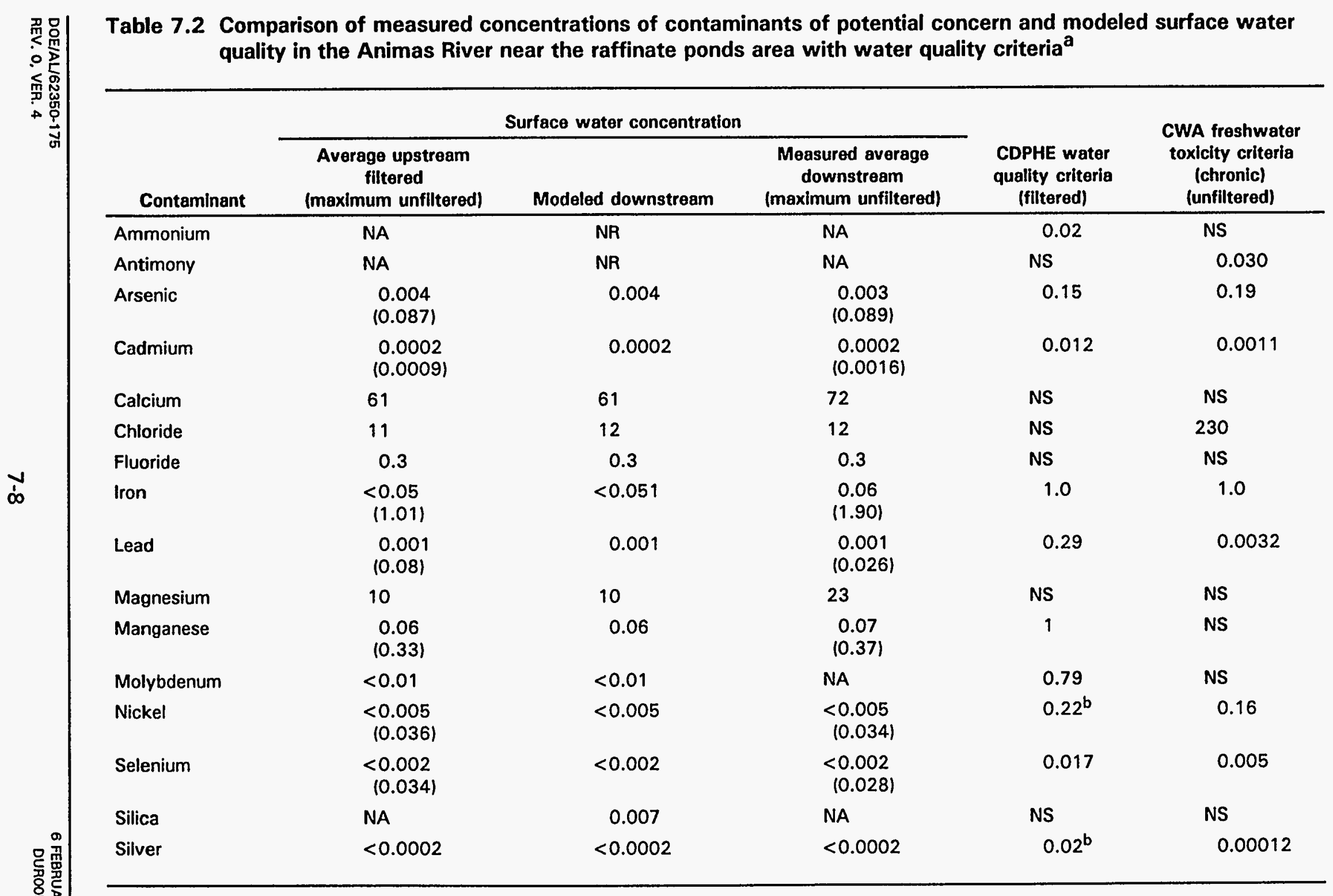




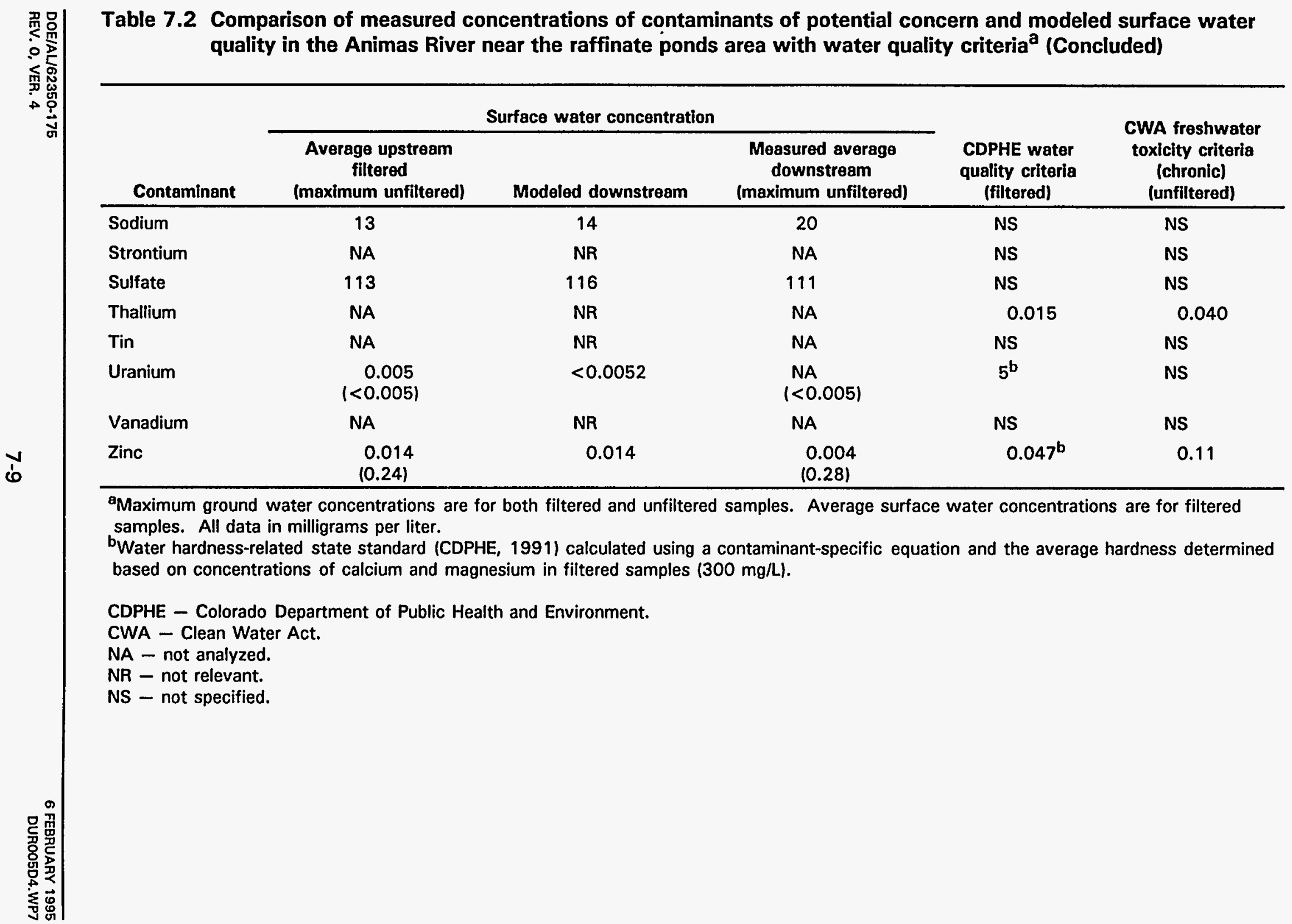


measured in these unfiltered samples could include suspended solids or sediments.

The top several inches of sediment were sampled at several locations near the site, including one immediately upstream of Lightner Creek (which is used as a background sample). Samples were analyzed for a limited suite of analytes associated with the site, as shown in Table 3.16. This sampling was conducted to determine whether levels in near-surface sediment posed an immediate threat to aquatic biota. Comparison of the upstream concentration to the maximum detected downstream concentration indicates that arsenic and iron occur at more than twice the upstream concentration. There are not sufficient data to determine whether this is significantly elevated statistically.

Constituents detected in Lightner Creek surface water and near-surface sediments are compared to upstream locations, as shown in Tables 3.15 and 3.16. Based on this single sampling event, there do not appear to be siterelated impacts to surface water or sediment from Lightner Creek. Again, additional data would be needed to more definitively evaluate these sediments.

\subsubsection{Fish tissue data}

The BOR has collected and analyzed fish from the Animas River. Two of the sampling locations (approximately $5 \mathrm{mi}[8 \mathrm{~km}$ ] upstream and downstream of the UMTRA Project site) may be relevant to the site because fish living some portion of their lifespan near the site could travel this distance both upstream and downstream from the site. Some of the levels of constituents associated with the site are high in fish tissue compared to national ranges; however, there are many sources of these same elements in the river, including natural occurrence of the minerals along the river path, mining, other mill sites, and municipal and industrial discharges. Because of the habitat range of fish and these multiple sources of contaminants, the significance, if any, of these data with respect to the Durango site cannot be determined.

\subsection{POTENTIAL IMPACTS TO WILDLIFE AND PLANTS}

\subsubsection{Terrestrial risk}

A number of potential exposure pathways were evaluated to determine risk to terrestrial flora and fauna from exposure to contaminants in ground water and surface water. Terrestrial vegetation can be directly exposed to contaminants in ground water through root uptake where ground water occurs near the surface. Contaminants may bioaccumulate in various plant parts and exert a wide range of influence, depending on the specific contaminant. Plant uptake rates vary greatly among species and are affected by factors such as soil characteristics (e.g., pH, moisture, redox potential, organic matter), plant sensitivity, inputoutput balances, or cumulative effects of various factors. 
Foraging wildlife can be indirectly exposed to contaminants in ground water by ingesting plants that may have bioaccumulated certain contaminants. Terrestrial wildlife can also be exposed to contaminants in surface water directly by ingesting ground water seeps or sediments or indirectly by ingesting aquatic organisms that have accumulated contaminants from sediments.

\section{Vegetation}

In areas where the depth to ground water is shallow, some plants could have rooting zones in soils that contain contaminated ground water. These contaminants could be phytotoxic (poisonous to plants) and could transfer to the food chain. Concentrations of the contaminants of potential concern in plant tissue, based on uptake from ground water, could not be estimated from available data. The UMTRA Project is currently conducting plant uptake studies; the results will be included in future site documents.

Table 7.3 shows concentrations of contaminants of potential concern that are toxic to plants when grown hydroponically in nutrient solutions with these concentrations. Ground water concentrations of arsenic, cadmium, lead, manganese, selenium, thallium, vanadium, and zinc exceeded the phytotoxicity values, indicating plant growth could be hindered.

\section{Wildlife}

The exposure of terrestrial organisms from ingesting plants or animals with accumulated contaminants is a potential exposure pathway at this site. Birds and other vertebrates consuming these plants and animals can bioaccumulate some of the contaminants of potential concern if the amount ingested exceeds the amount eliminated. This is often a function of the areal extent of contamination versus the areal extent of the animal's feeding range. Therefore, although exposure via the diet may be possible, the potential for bioaccumulation is not always a concern.

Biomagnification is a potentially more severe situation in which the concentration of a constituent increases in higher levels of the food chain because the contaminants are accumulated through each successive trophic level. Of particular concern for biomagnification effects are the top predators, especially carnivorous birds and mammals. Only a limited number of constituents have the potential for magnifying in the food chain. Based on available information on the contaminants of potential concern and the limited areal extent of potentially affected vegetation, the potential for the contaminants to present a hazard via food chain transfer is probably low.

Other potential pathways of exposure to wildlife include the ingestion of water from ground water seeps or affected soils. Additional characterization of the site would be needed to determine whether these exposures occur and whether they represent a risk to wildlife. 
Table 7.3 Comparison of contaminants of potential concern in ground water with available water quality values and phytotoxic concentrations, Durango, Colorado, site ${ }^{a}$

\begin{tabular}{|c|c|c|c|c|}
\hline \multirow[b]{2}{*}{ Contaminant } & \multicolumn{2}{|c|}{ Maximum detected concentration } & \multirow[b]{2}{*}{$\begin{array}{c}\text { Aquatic life } \\
\text { water quality } \\
\text { value }\end{array}$} & \multirow[b]{2}{*}{$\begin{array}{c}\text { Concentration in } \\
\text { water toxic to } \\
\text { plants }\end{array}$} \\
\hline & $\begin{array}{l}\text { Mill tailings area } \\
\text { (DUR-01-612) }\end{array}$ & $\begin{array}{l}\text { Raffinate ponds area } \\
\text { (DUR-02-602) }\end{array}$ & & \\
\hline Ammonium & 0.2 & 3.5 & $0.02^{d}$ & NA \\
\hline Antimony & $0.023(0.025)$ & ND & 0.030 & NA \\
\hline Arsenic & $0.05(<0.005)$ & $0.164(0.04)$ & 0.15 & 0.001 \\
\hline Barium & $0.03(<0.1)$ & $0.01(<0.1)$ & NS & NA \\
\hline Cadmium & $0.07(0.0475)$ & $0.081(<0.001)$ & $0.012^{8}$ & 0.05 \\
\hline Calcium & $476.5(449.5)$ & $491(475)$ & NS & NA \\
\hline Chloride & 795 (955.5) & $2400(2380)$ & 230 & NA \\
\hline Copper & $0.03(<0.02)$ & $0.02(<0.02)$ & $0.159^{e}$ & 0.03 \\
\hline Fluoride & $1.7(1.2)$ & $0.4(0.2)$ & NS & NA \\
\hline Iron & $0.12(1.26)$ & $1.11(2.45)$ & 1 & 10 \\
\hline Lead & $0.03(0.012)$ & $0.07(<0.01)$ & $0.27^{e}$ & 0.02 \\
\hline Lead-210 & (3.4 pCi/L) & ND & NS & NA \\
\hline Magnesium & 306 (299.5) & $724(644)$ & NS & NA \\
\hline Manganese & $6.70(6.185)$ & $1.62(1.40)$ & 1 & 4 \\
\hline Molybdenum & $0.27(0.13)$ & $0.15(<0.01)$ & $0.79^{f}$ & 0.5 \\
\hline Nickel & $0.05(<0.04)$ & $0.05(<0.04)$ & $0.93^{\theta}$ & 0.2 \\
\hline Nitrate & (6.5) & $13.7(<1)$ & $90^{9}$ & NA \\
\hline Polonium-210 & $(0.1 \mathrm{pCi} / \mathrm{L})$ & (0.1 pCi/L) & NS & NA \\
\hline Radium-226 & $\begin{array}{l}0.5 \mathrm{pCi} / \mathrm{L} \\
(1.2 \mathrm{pCi} / \mathrm{L})\end{array}$ & $\begin{array}{c}0.2 \mathrm{pCi} / \mathrm{L} \\
(0.1 \mathrm{pCi} / \mathrm{L})\end{array}$ & $5 \mathrm{pCi} / \mathrm{L}$ & NA \\
\hline Selenium & $0.226(0.074)$ & $0.763(0.063)$ & 0.005 & 0.7 \\
\hline Silica & $23.2(22.7)$ & $24.9(22.8)$ & NS & NA \\
\hline Silver & $0.03(<0.01\}$ & $0.04(<0.01)$ & $0.055^{\circ}$ & 0.1 \\
\hline Sodium & $1200(1190)$ & $5000(3260)$ & NS & NA \\
\hline Strontium & 3.42 & 11.1 & NS & NA \\
\hline Sulfate & $3360(3090)$ & $11,100(7720)$ & NS & NA \\
\hline Thallium & $0.01(<0.005)$ & $0.06(<0.01)$ & 0.015 & 0.02 \\
\hline Thorium-230 & $(0.95 \mathrm{pCi} / \mathrm{L})$ & (1.4 pCi/L) & $60 \mathrm{pCi} / \mathrm{L}$ & NA \\
\hline $\operatorname{Tin}$ & $0.068(0.015)$ & $0.199(0.133)$ & NS & 100 \\
\hline Uranium & 4.67 (3.985) & $0.602(0.101)$ & $41^{\circ}$ & 40 \\
\hline
\end{tabular}


Table 7.3 Comparison of contaminants of potential concern in ground water with available water quality values and phytotoxic concentrations, Durango, Colorado, site ${ }^{a}$ (Concluded)

\begin{tabular}{lcccc}
\hline & \multicolumn{2}{c}{ Maximum detected concentration } & Aquatic life \\
Contaminant & $\begin{array}{c}\text { Mill tailings area } \\
\text { (DUR-01-612) }\end{array}$ & $\begin{array}{c}\text { Raffinate ponds area } \\
\text { (DUR-02-602) }\end{array}$ & $\begin{array}{c}\text { Concentration in } \\
\text { water quality } \\
\text { value }\end{array}$ & $\begin{array}{c}\text { water toxic to } \\
\text { plants }^{\mathrm{b}}\end{array}$ \\
\hline Vanadium & $0.61(0.505)$ & $0.07(<0.01)$ & NS & 0.5 \\
Zinc & $3.27(3.185)$ & $0.021(0.015)$ & $1.3^{e}$ & 0.4 \\
\hline
\end{tabular}

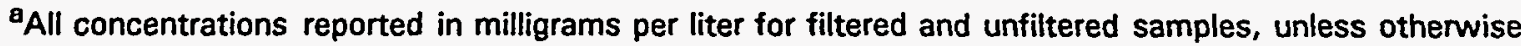
specified. Unfiltered concentrations are in parentheses. If two concentrations are not provided, filtered and unfiltered samples were not analyzed for this constituent.

bThe lower of the values specified by the Colorado Department of Public Health and Environment (CDPHE) or by the Clean Water Act (CWA). CDPHE values are obtained from the Basic Standards and Methodologies for Surface Water, 3.1.0 (5 CCR 1002-8), CDPHE, Water Quality Control Commission (CDPHE, 1991). Aquatic quality are standards protective of aquatic life via chronic exposure and are for filtered samples.

Agricultural-use values are based on total recoverable metals. CWA values are obtained from EPA, 1991. CDPHE values were used for hardness-dependent criteria.

'Tested concentrations that caused at least a 20 percent reduction in plant growth or yield when grown in nutrient solutions (Will and Suter, 1994).

dValue is for ammonia.

'Water hardness-related state standard (CDPHE, 1991), calculated using a contaminant-specific equation and the average hardness determined for calcium and magnesium from filtered samples.

$f^{\prime}$ No state or federal criteria are available. Value presented is for newly fertilized eggs of rainbow trout, which are sensitive to molybdenum concentrations above $0.79 \mathrm{mg} / \mathrm{L}$ (Eisler, 1989).

9No state or federal criteria are available. Value presented is the concentration at or below which no adverse effects are expected for warmwater fish (EPA, 1986).

NA - not available.

NS - no state or federal water quality standard or criteria available.

ND - not detected above method detection limit.

$\mathrm{pCi} / \mathrm{L}$ - picocuries per liter. 


\subsubsection{Aquatic risk}

\section{Surface water}

Based on modeling of contaminated ground water flow into surface water, limited sampling, and comparison of these modeled and detected values to water quality criteria, no increment of risk to aquatic receptors would be expected from surface water in Lightner Creek and the Animas River. However, cadmium, iron, and zinc maximum observed concentrations in unfiltered water samples slightly exceed levels protective of or toxic to aquatic life (Tables 7.1 and 7.2). While no water quality data are available for calcium, magnesium, and sodium, these chemicals are considered to be essential nutrients and are not associated with toxicity at the observed or modeled concentrations. No water quality data are available for fluoride, silica, strontium, sulfate, tin, and vanadium, but their very low estimated concentrations are not expected to be associated with toxicity.

\section{Sediment}

There are no established state or federal sediment quality criteria for the protection of aquatic life for inorganic contaminants. The EPA is evaluating a methodology based on the three-phase sorption model for free metal ion activity and is assessing its applicability for determining the bioavailable fraction within sediments (EPA, 1989d). Several other predictive models and methods are being investigated for metals, but no single approach has been accepted to adequately develop sediment-based metals criteria (Shea, 1988; Chapman, 1989d; EPA, 1989; NOAA, 1990; OMOE, 1990; DiToro et al., 1991; Burton, 1991). The lack of adequate criteria coupled with the limited sediment sampling conducted at the site preclude a thorough evaluation of sediments at this time.

National Oceanic and Atmospheric Administration (NOAA) effects-based sediment quality values are available for evaluating the potential for constituents in sediment to cause adverse biological effects. These values are not standards or criteria. Effects range-low (ER-L) values are concentrations equivalent to the lower 10th percentile of available data screened by NOAA; these values indicate the low end of the concentration range in specific sediments at which adverse biological effects were observed for various organisms. The NOAA ER-L values are compared with the concentrations of the contaminants of potential concern detected in sediment of the Animas River (Table 7.4). The ER-L cannot be used as a direct indicator of adverse effects to benthic organisms, but it may provide a benchmark for evaluating the potential for adverse effects.

Sediment quality values are available for arsenic, iron, lead, and zinc. In the Animas River, the ER-L value for iron was exceeded at sample locations 656 and 654; the ER- $L$ values for lead and zinc were exceeded at sample locations 691 , 657,656 , and 654 , and in upstream location 652 . Based on the available information, there is a limited potential for concentrations of iron, lead, and zinc to adversely affect benthic organisms. It is not known whether these concentrations are primarily naturally occurring or whether they are site-related. 


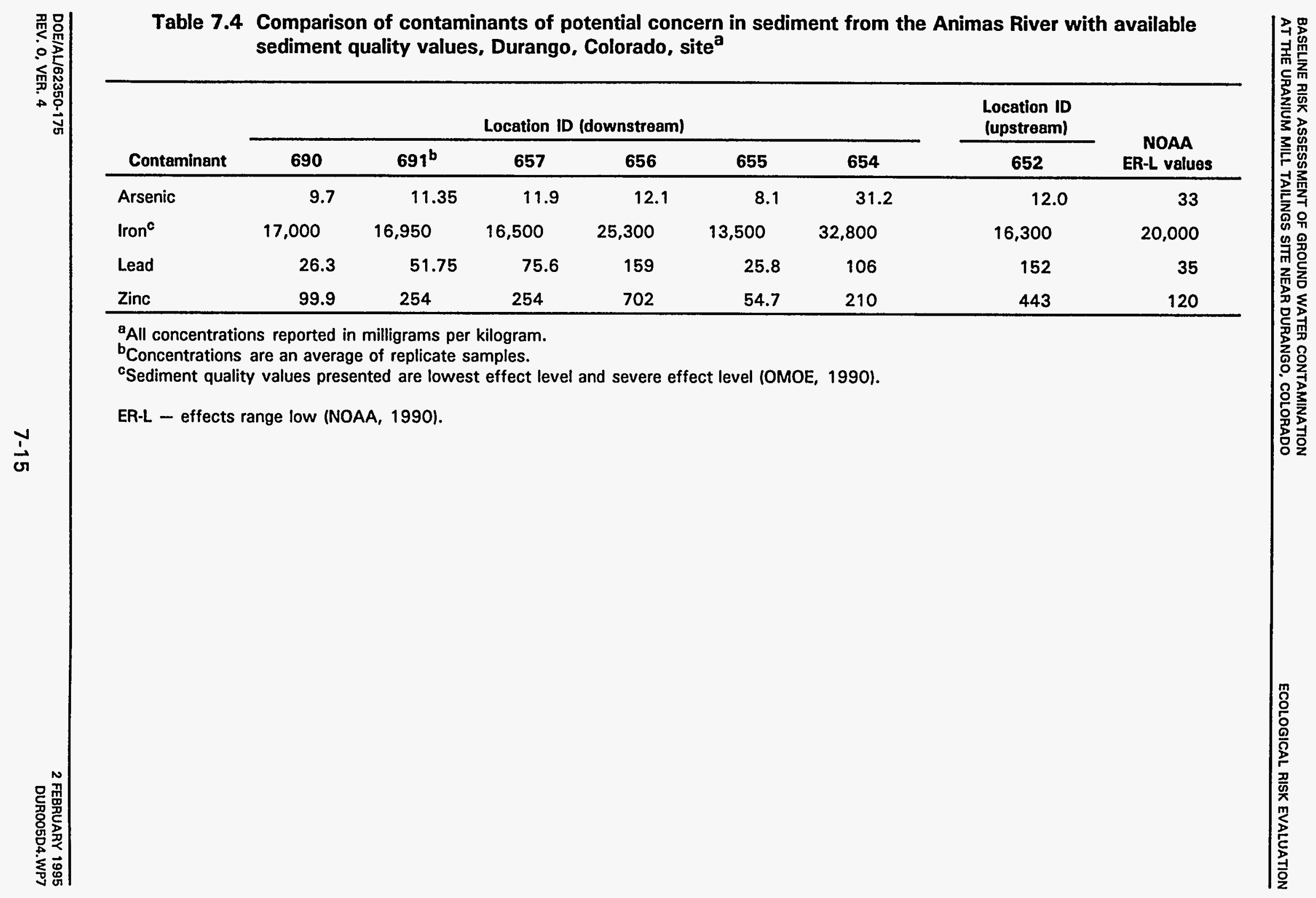




\section{Ground water}

Potential risks to aquatic life that might be exposed directly to ground water (e.g., if a pond were constructed and filled with ground water) were evaluated. Maximum concentrations in filtered samples of all constituents detected in ground water at each location were compared to available water quality values (Table 7.3). In mill tailings area ground water, concentrations of ammonium, cadmium, lead, manganese, selenium, silver, and zinc exceeded levels protective of or toxic to aquatic life. In the raffinate ponds area, concentrations of ammonium, arsenic, cadmium, chloride, iron, lead, manganese, selenium, silver, and thallium exceeded levels protective of or toxic to aquatic life. Therefore, ground water would not be suitable for filling a pond.

\subsection{LIMITATIONS OF THE ECOLOGICAL RISK ASSESSMENT}

The qualitative evaluation of potential ecological risks presented here is a screening-level assessment. Sources of uncertainty in any ecological assessment arise from the monitoring data, exposure assessments, toxicological information, and inherent complexities of the ecosystem. In addition, methods of predicting nonchemical stresses (e.g., drought), biotic interactions, behavior patterns, biological variability (e.g., differences in physical conditions, nutrient availabilityl, and resiliency and recovery capacities are often unavailable. In general, limitations for the Durango ecological risk assessment include the following:

- Only a small amount of ecological data was collected during this screening.

- Little is known about site-specific intake rates for wildlife or amounts of contaminants taken up by plants.

- Only limited ecotoxicological reference data are available.

- Considerable uncertainty is associated with the toxicity of mixtures.

\subsection{SUMMARY}

This screening-level ecological risk assessment evaluated the potential for adverse impacts to terrestrial flora and fauna and to aquatic organisms associated with exposure to sediment, ground water, and surface water contamination at the Durango site.

Based on limited sampling and on the use of ground- to surface-water flow models, no increment of risk from the site to ecological receptors is expected from surface water in Lightner Creek and the Animas River.

Based on available sediment data, it is difficult to determine whether sediments at the site are contaminated from site-related activities. Concentrations of iron, 
lead, and zinc detected in sediments, reflecting both background levels and possible site contributions, slightly exceeded sediment quality values.

There were also not sufficient data to evaluate potential risks to or from plants that may have roots in contact with soil saturated with contaminated ground water at the mill tailings area and the raffinate ponds area. Concentrations of many contaminants of potential concern in ground water exceed levels that are phytotoxic.

The potential for the contaminants of potential concern detected in media at the site to represent a food chain hazard (via bioaccumulation and biomagnification) is probably low, based on the limited areal extent and accessibility of contaminants. However, no plant or animal tissue analyses have been conducted at this site.

In summary, limited water and sediment quality values were available to evaluate the impact of contaminated sediments and ground water on ecological receptors. As with any qualitative ecological risk assessment, the uncertainty inherent in this assessment can be reduced through additional characterization and evaluation. 


\subsection{INTERPRETATION AND RECOMMENDATIONS}

\subsection{RISK SUMMARY}

The UMTRA Project is required by the UMTRCA to protect public health and the environment from radiological and nonradiological hazards associated with 24 designated uranium mill sites. This baseline risk assessment was conducted for the Durango site to evaluate the presence of these hazards at both the mill tailings and raffinate ponds areas. Because contaminated ground water is not being used by area residents, human health is not currently at risk. This situation will continue if land use and water use at the site remain the same.

Health risks could be associated with potential future use of contaminated ground water from both the mill tailings and raffinate ponds areas; however, such use is unlikely. At the mill tailings area, the risks associated with potential future use of ground water for drinking are unacceptable for manganese, molybdenum, sodium, sulfate, and lead. Severe diarrhea could result in infants (the most sensitive population group) from short-term exposures to sulfate levels. Therefore, sulfate acute toxicity could preclude chronic exposures. However, because different ground water contaminants flush out at different rates and because remedial action strategies may differ for different contaminants, the effects from long-term exposures to contaminants other than sulfate are also discussed. This water is potentially in the mild toxicity range following chronic ingestion exposures to manganese and sodium. Manganese levels could produce minor neurological symptoms, and sodium levels could cause hypertension. Mineral imbalances resulting from copper excretion from the body could be associated with molybdenum exposure levels. Lead levels could initiate subtle hematological or behavioral changes in potentially exposed children. If this ground water were used for drinking water, potential lifetime exposures to radioactive uranium and progeny of natural uranium decay series could be associated with an excess lifetime cancer risk of about 1 in 1000; this exceeds the maximum excess cancer risk of 1 in 10,000 recommended by the EPA for Superfund sites (40 CFR Part 300 (1994)).

At the raffinate ponds area, sulfate ingestion by humans and animals would represent the primary risk associated with future use of contaminated ground water. Drinking ground water from the contaminated zone could result in sulfate intakes in the potentially lethal range for infants following even shortterm exposures. Sulfate levels are associated with severe diarrhea, which may lead to severe dehydration. However, these levels of sulfate and other ground water contaminants would cause water to be essentially unpalatable, thus reducing its potential for consumption. Although this sulfate toxicity could preclude chronic exposures, as with the mill tailings area, the effects from longterm exposures to contaminants other than sulfate are also discussed. Manganese, sodium, chloride, molybdenum, cadmium, and selenium levels are potentially in the range of mild toxicity. The manganese concentrations could be associated with the development of mild neurological symptoms, the 
molybdenum concentrations could lead to copper deficiency, and the selenium concentrations could result in nail and hair brittleness or loss. Cadmium levels could result in symptoms of kidney toxicity, including proteinuria. Lead levels could cause hematological or behavioral changes in exposed children. Finally, the sodium and chloride levels could result in hypertension. Diarrhea-caused dehydration may enhance the toxicity of other contaminants, especially cadmium, manganese, molybdenum, sodium, selenium, and lead. For the raffinate ponds area, lifetime excess cancer risks associated with uranium and progeny of uranium decay series (about 2 in 10,000), and arsenic (about 4 in $1000)$ are also at levels that exceed the maximum excess cancer risk of 1 in 10,000 recommended by the EPA (40 CFR Part 300 (1994)).

The potential exposure contribution from other pathways, including ingestion of produce, meat, or fish, could not be estimated with current data. Although drinking water ingestion is assumed to result in the greatest exposure, other pathways may contribute to overall exposure and are of interest because plant uptake and food chain transfer could occur under current site conditions.

The results of limited sampling and models of ground- to-surface-water flow demonstrate that no increment of risk from the site to ecological receptors is expected from surface water in Lightner Creek and the Animas River. It is difficult to determine from available sediment data whether sediments at the site are contaminated from site-related activities. Concentrations of iron, lead, and zinc detected in sediments, reflecting both background levels and possible site contributions, slightly exceeded sediment quality values. There also were not sufficient data to evaluate potential risks to or from plants that may have roots in contact with soil saturated with contaminated ground water at the mill tailings area and the raffinate ponds area. Concentrations of many contaminants of potential concern in ground water exceed levels that are phytotoxic. The potential for the contaminants of potential concern detected in media at the site to represent a food chain hazard (via bioaccumulation and biomagnification) is considered low, based on the limited accessibility of contaminants. However, no plant or animal tissue analyses have been conducted at this site.

\subsection{LIMITATIONS OF THIS RISK ASSESSMENT}

The following limitations to this evaluation of health and environmental risks should be noted:

- Because future land development is unknown, actual exposure pathways could not be determined.

- In general, the results presented in this document are based on filtered $(0.45-\mu \mathrm{m})$ water samples. The effect of filtration differs for different elements. Filtered samples for some constituents can have concentrations equal to or lower than unfiltered samples. Constituents in suspension may 
be lost with filtration but can still produce toxic effects if ingested and broken down in the acidic environment of the stomach.

- This risk assessment does not address all individual sensitivities to toxicity of contaminants of potential concern. Contaminant toxicities vary from person to person. Presenting probability distributions for potential exposure and exposure ranges that can produce toxic effects emphasizes these variabilities. However, it is not possible to account for all sources of variability. Specific subpopulations known to be more sensitive to toxicity of given constituents are noted. Adverse health effects might occur at lower exposure levels in sensitive individuals.

- Standardized reference values from regulatory agencies and literature values are used to determine toxic effects in humans. However, some data obtained from laboratory animal testing at exposure doses different from those expected at the site were used to determine toxicity. The relationship between dose and response is not always linear, and humans do not always exhibit the same responses as animals. Additionally, data used to determine toxicity generally are based on exposure to only the constituent of concern. In reality, exposures generally occur simultaneously to multiple constituents. The interactive effects of multiple constituents and the impact of these interactions on expected toxicity generally cannot be accurately assessed from existing data.

- Although considerable effort was directed at determining contaminated ground water movement and placing monitor wells in locations that capture maximum contamination, variability in physical systems and models used to determine contaminant plume migration could still result in well placements that do not measure the highest contaminant concentrations or determine the fullest extent of plume impact.

- Some variability may have been introduced through sampling and analytical processes. However, the data at UMTRA Project sites have been collected over many years and subjected to rigorous quality assurance procedures. Testing multiple samples introduces high confidence in the reliability and validity of the collected data.

- The incremental contribution from the ground water-irrigated produceingestion or meat-ingestion pathways to the total exposure, which could not be estimated here, could be significant. Therefore, the additivity of exposure from other pathways or from higher regional background levels or dietary intakes (e.g., from fish ingestion) should be considered.

- A limited amount of ecological data was collected for this screening. In addition, little is known about site-specific intake rates for wildlife and amounts of contaminants taken up by plants. Limited ecotoxicological reference data and considerable uncertainty associated with the toxicity of mixed contaminants add to the limitations of this risk assessment. 
By presenting ranges of toxic effects, probable exposure distributions, summaries of available data on health effects and interactions, and outlines of potential limitations, this risk assessment ensures a reasonable interpretation of potential health risks associated with ground water contamination at this site. The assessment describes contamination and risk as accurately as possible, based on available data, and conveys areas of uncertainties.

\subsection{GROUND WATER CRITERIA}

In 1983, the EPA established health and environmental protection standards for the UMTRA Project (40 CFR Part 192). The standards were revised and the final rule was published 11 January 1995 (60 FR 2854 (1995)). The ground water standards consist of ground water protection standards to evaluate disposal cell performance and ground water cleanup standards for existing contamination at processing sites. Concentration limits for constituents at the mill tailings and raffinate ponds areas are summarized in Tables 8.1 and 8.2, respectively. Maximum concentration limits $(M C L)$ are not established for every contaminant; for contaminants without MCLs, background levels must be met. The standards also allow for supplemental standards or alternate concentration limits (ACL) where appropriate.

While these ground water standards apply specifically to the UMTRA Project, the EPA has also published drinking water health advisory levels for both longterm and short-term exposures. These advisories are also shown in Tables 8.1 and 8.2 .

At the mill tailings area (Table 8.1), ground water concentrations for antimony, cadmium, lead, molybdenum, selenium, vanadium, zinc, and uranium have consistently exceeded the EPA ground water standards and/or the EPA health advisory levels.

For the raffinate ponds area (Table 8.2), ground water concentrations for antimony, lead, molybdenum, selenium, thallium, vanadium, and uranium have consistently exceeded the EPA ground water standards and/or the EPA health advisory levels.

\section{$8.4 \quad$ RISK MITIGATION MEASURES}

Short-term use of the contaminated ground water from the shallow aquifer beneath the Durango site could cause adverse health effects. The former processing site is located adjacent to the city of Durango and may be developed in the future. Although water from the affected aquifer is not known to be used for any purpose, the contaminated ground water may express itself in the form of seeps or discharges into the Animas River. Therefore, access to the ground water should be restricted. However, the rates of discharge are significantly small compared to the flow in the Animas River. 


\begin{tabular}{|c|c|c|c|}
\hline \multirow[b]{2}{*}{ Constituent } & $\begin{array}{l}\text { EPA maximum concentration of } \\
\text { constituents in ground water } \\
\text { for UMTRA Project sites }\end{array}$ & $\begin{array}{l}\text { Health advisories, } 10-\mathrm{kg} \\
\text { child, 10-day }\end{array}$ & $\begin{array}{l}\text { Health advisories, } 70-\mathrm{kg} \\
\text { adult, lifetime }\end{array}$ \\
\hline & \multicolumn{3}{|c|}{ (mg/L) } \\
\hline \multicolumn{4}{|l|}{ Chemical (inorganic) } \\
\hline Antimony ${ }^{a}$ & NA & $0.015^{b}$ & $0.003^{b}$ \\
\hline Arsenic & 0.05 & NA & NA \\
\hline Barium $^{a}$ & 1.0 & NA & 2 \\
\hline Boronc & NA & 0.9 & 0.6 \\
\hline Cadmium & $0.01^{b}$ & $0.04^{b}$ & $0.005^{b}$ \\
\hline Chromium $^{a}$ & 0.05 & 1.0 & 0.1 \\
\hline Lead & 0.05 & NA & $0.015^{b, d}$ \\
\hline Mercury ${ }^{a}$ & 0.002 & NA & 0.002 \\
\hline Molybdenum & $0.1^{b}$ & $0.08^{b}$ & $0.04^{b}$ \\
\hline Nickel $^{\mathrm{a}}$ & NA & 1.0 & 0.1 \\
\hline Nitrate & $44^{e}$ & $44^{f}$ & NA \\
\hline Selenium & $0.01^{b}$ & NA & NA \\
\hline Silver ${ }^{a}$ & 0.05 & 0.2 & 0.1 \\
\hline Strontium ${ }^{a}$ & NA & 25.0 & 17 \\
\hline Thallium $^{a}$ & NA & 0.007 & 0.0004 \\
\hline Vanadium & NA & $0.08^{b}$ & $0.02^{b}$ \\
\hline Zinc & NA & 6.0 & $2^{b}$ \\
\hline
\end{tabular}


Table 8.1 Concentration limits of constituents for the ground water at the mill tailings area, Durango, Colorado, site (Concluded)

\begin{tabular}{lccc}
\hline & $\begin{array}{c}\text { EPA maximum concentration of } \\
\text { constituents in ground water } \\
\text { for UMTRA Project sites }\end{array}$ & $\begin{array}{c}\text { Health advisories, 10-kg } \\
\text { child, 10-day }\end{array}$ & $\begin{array}{c}\text { Health advisories, 70-kg } \\
\text { adult, lifetime }\end{array}$ \\
\cline { 2 - 4 } Constituent & & & \\
\hline Radionuclide & $5 \mathrm{mg} / \mathrm{L})$ & \\
Radium-226/-228 & $5 \mathrm{pCi} / \mathrm{L}$ & $0.1 \mathrm{mg} / \mathrm{L}^{\mathrm{b}, g}$ \\
$\begin{array}{l}\text { Uranium } \\
\text { (U-234/-238) }\end{array}$ & $\begin{array}{l}30 \mathrm{pCi} / \mathrm{L}^{\mathrm{b}} \\
(0.044 \mathrm{mg} / \mathrm{L})\end{array}$ & $0.03 \mathrm{mg} / \mathrm{L}^{\mathrm{b}, \mathrm{g}}$ & \\
\hline
\end{tabular}

a Not monitored in background wells from 1990 to 1994.

${ }^{b}$ Exceeded in contaminated well samples.

CNot monitored in background and contaminated wells from 1990 to 1994.

Action level.

$\mathrm{e}_{\text {Equal }} 10 \mathrm{mg} / \mathrm{L}$ nitrate as nitrogen.

†Under review.

gproposed value, under review; revision expected in 1995.

$\mathrm{kg}$ - kilogram.

$\mathrm{mg} / \mathrm{L}$ - milligrams per liter.

$\mathrm{pCi} / \mathrm{L}$ - picocuries per liter.

NA - not available. 


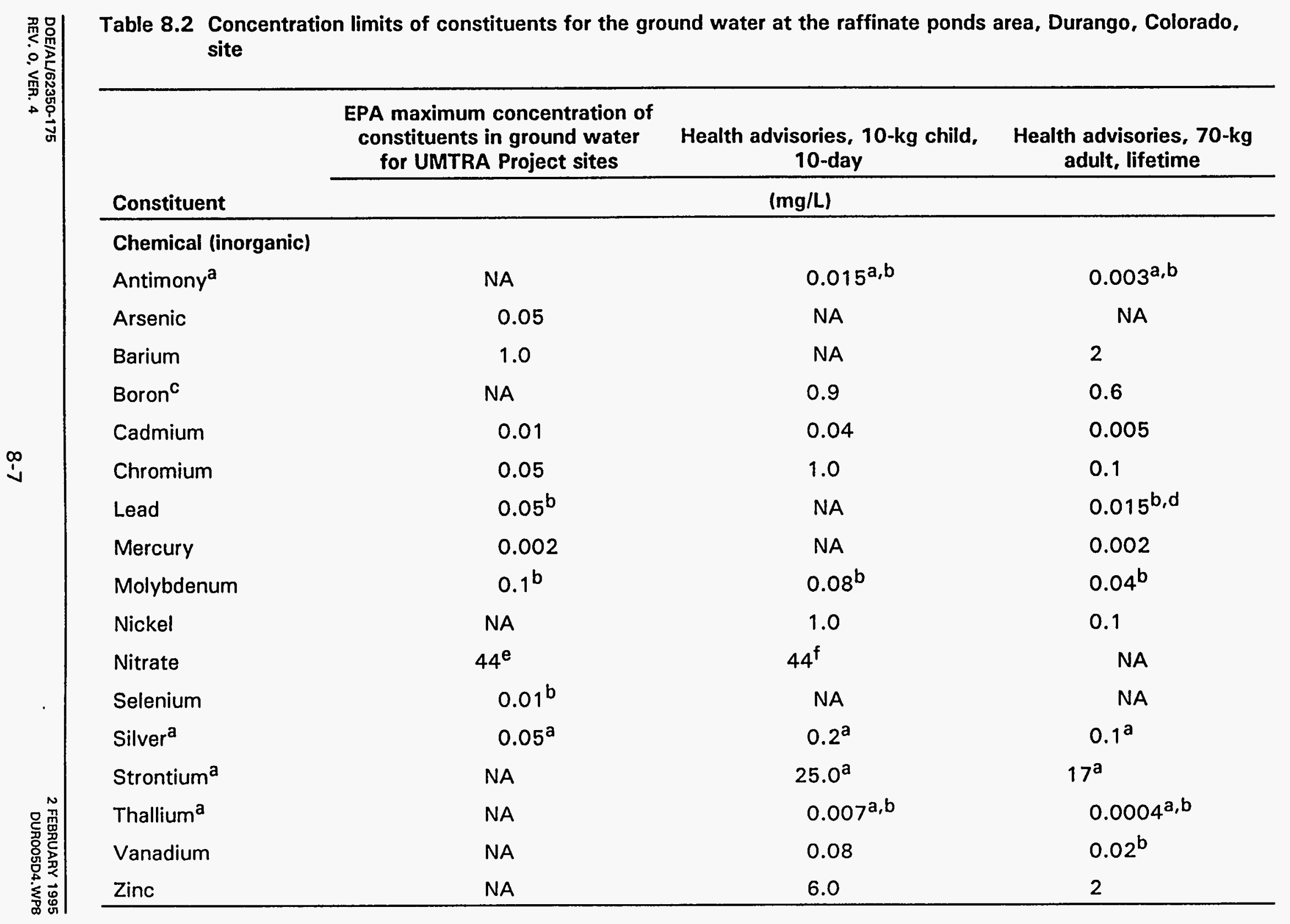


Table 8.2 Concentration limits of constituents for the ground water at the raffinate ponds area, Durango, Colorado, site (Concluded)

\begin{tabular}{lcccc}
\hline & $\begin{array}{c}\text { EPA maximum concentration of } \\
\text { constituents in ground water } \\
\text { for UMTRA Project sites }\end{array}$ & & $\begin{array}{c}\text { Health advisories, 10-kg } \\
\text { child, 10-day }\end{array}$ & $\begin{array}{c}\text { Health advisories, 70-kg } \\
\text { adult, lifetime }\end{array}$ \\
\cline { 2 - 3 } Constituent & (pCi/L) & (mg/L) \\
\hline Radionuclide & 5 & & \\
Radium-226/-228 & $30^{\mathrm{b}}$ & $0.03^{\mathrm{b}, \mathrm{g}}$ & $0.1^{\mathrm{b}, \mathrm{g}}$ \\
$\begin{array}{l}\text { Uranium } \\
(U-234 /-238)\end{array}$ & $(0.044 \mathrm{mg} / \mathrm{L})$ & & \\
\hline
\end{tabular}

a Not monitored in background wells from 1990 to 1994.

${ }^{b}$ Exceeded in contaminated well samples.

${ }^{C}$ Not monitored in background and contaminated wells from 1990 to 1994.

dAction level.

Equal $10 \mathrm{mg} / \mathrm{L}$ nitrate as nitrogen.

fUnder review.

gproposed value, under review; revision expected in 1995.

$\mathrm{mg} / \mathrm{L}$ - milligrams per liter.

$\mathrm{kg}$ - kilograms.

NA - not available.

$\mathrm{pCi} / \mathrm{L}$ - picocuries per liter. 
The EPA ground water standards define institutional controls as mechanisms that can be effectively used to protect human health and the environment by controlling access to contaminated ground water. Although the standards refer to institutional controls for long periods of time (e.g., up to 100 years during natural flushing), they can also be applied to short-term restriction of access to contaminated ground water. Since not all 24 UMTRA Project sites can be evaluated simultaneously, short-term institutional controls may be needed before remedial action decisions are made and implemented for individual sites.

\section{Well permits}

All of the Colorado UMTRA Project sites are located on the Colorado Western Slope and are outside designated ground water basins. Designated basins are isolated hydrogeologic areas where ground water use is stringently evaluated based on the demands for water rights. Construction of a new well in Colorado outside designated basins requires a written application to the State Engineer for a permit. The State Engineer is required to act on applications for new well permits within $\mathbf{4 5}$ days after their receipt. If a well would affect existing water rights or if an applicant wants to establish a legal right, adjudication would likely be required prior to the permit being granted.

\section{Ground water quality}

The Colorado Department of Public Health and Environment (CDPHE) is the state agency responsible for setting water quality standards. Within the CDPHE, the State Water Quality Control Commission is responsible for adopting water quality standards and classifications for state waters.

The state of Colorado's proposed ground water quality standards require ground water to be free of substances in concentrations shown to be "carcinogenic, mutagenic, teratogenic or toxic to human beings and/or a danger to public health, safety, or welfare." (CDPHE, 1990).

The State Engineer is authorized to enforce the state water quality standards. However, the State Engineer does not have jurisdiction to deny a permit for drilling a new well based on water quality, because domestic well water quality is not regulated by the state. The State Engineer's office can issue a warning to well users if the well is placed in a known contaminated aquifer. Well water to be consumed by 25 or more people does have to meet state water quality standards, and use can be restricted by the CDPHE, Water Quality Control Division, Drinking Water Section.

\section{Land restrictions}

The former processing site is outside the Durango city limits and is currently not subject to city requirements. La Plata County currently has jurisdiction over the former processing site. However, the land is within the city planning and service area. Use of city utilities requires that all city ordinances be followed. 
The city of Durango Code of Ordinances, Chapter 27, The Land Use and Development Code, Article 10, Section 1053 (b), stipulates that all development should be served by the Durango public water system. This ordinance prohibits wells within the city limits. If the former processing site is annexed by the city, it would be subject to the city requirements and restrictions. Land use on the site would have to be approved by the city in consultation with the state and potential property users. Currently, any proposed development of the former processing site would be subject to a joint review by both the city of Durango and La Plata County.

\subsection{RECOMMENDATIONS}

In general, the EPA ground water standards consisting of MCLs or background concentrations are sufficient to protect human health and the environment. However, in some cases, a risk assessment may identify site-specific factors that suggest these standards may either be too restrictive or not restrictive enough. When standards are too restrictive, there may be no potential for exposure, and a less restrictive ACL may be sought. In other cases, the standards may not be sufficiently protective (e.g., if many contaminants are near the MCL with additive or synergistic adverse health effects).

At Durango, there is no permanent physical barrier to prevent access to contaminated ground water at the former uranium processing site. Therefore, ACLs could not be justified for constituents with MCLs. However, for constituents that exceed background levels and do not have MCLs, this risk assessment suggests that background levels are more restrictive than necessary. This includes contaminants that were screened out because their concentrations fall within nutritional levels (such as chromium, copper, and zinc) and other contaminants (such as ammonium, nickel, strontium, and tin) that were demonstrated to be at concentrations well below adverse health effect levels. ACLs may be sought for these contaminants.

The levels of sulfate present a serious health risk if contaminated ground water at the raffinate ponds area were used for drinking water. Although such use is unlikely, the levels within the contamination zone substantially exceed levels that are reported elsewhere to cause diarrhea leading to dehydration in infants. Therefore, future ground water use in the areas of contamination should be prevented until the level of contamination is reduced.

When specific land uses are determined for the site, these uses should be evaluated at that time to identify potential health and environmental risks from the contaminated media. For example, excavation is an activity that could involve such risks.

Comprehensive ground water characterization was not required to accomplish surface cleanup. Under the UMTRA Ground Water Project, additional investigations will be needed to better define the ground water contamination so that compliance strategies and their associated risks can be evaluated. These 
investigations will also provide information needed to determine contaminant impact, if any, to sediment, plants, wildlife, and aquatic life. 


\subsection{LIST OF CONTRIBUTORS}

The following individuals were primarily responsible for the preparation of this report.

\begin{tabular}{ll}
\hline Name & Contribution \\
\hline B. Malczewska-Toth & Risk assessment; toxicology \\
L. Flowers & Pathway analysis; ecology \\
K. Smith, J. Weidner & Statistics \\
D. Tarbox & Hydrogeology \\
T. Jackson, D. Erskine & Geochemistry \\
R. Neri Zagal & Document coordination; risk mitigation measures \\
B. Brattin, J. Gibb & Senior technical review \\
R. Saar, A. Holm, & Technical review \\
J. Senger & \\
J. Senger & Site manager \\
D. Thalley & Technical editing \\
L. Sanchez, L. Lavigne & Text processing \\
J. Gates, S. Suniga, & Graphic design \\
\hline
\end{tabular}




\subsection{REFERENCES}

Aiyar, A. S., and A. Sreenivasan, 1961. Proc. Soc. Exp. Biol. Med., Vol. 107. pp. 914-916.

Alexander et al. (F. W. Alexander, B. E. Clayton, and H. T. Delves), 1974. Quarterly Journal of Medicine, Vol. 53, pp. 89-111.

Ballou et al. (J. E. Ballou, R. A. Gies, A. C. Case, D. L. Haggard, R. L. Buschbom, and J. L. Ryan), 1986. "Deposition and Early Disposition of Inhaled Uranium-233 Uranyl Nitrate and Uranium-232 Uranyl Nitrate in the Rat," in Health Physics, No. 51, pp. 755-772.

Belehova, B. A., 1969. Scientific Transactions of the Irkutsk State Medical Institute, Vol. 96, pp. 20-23 (in Russian).

Berlin, M., and B. Rudell, 1986. "Uranium," in Handbook on the Toxicology of Metals, second edition, L. Friberg, G. F. Nordberg, and V. B. Vouk, eds., pp. 647-658, Elsevier Science Publishers, Amsterdam.

BFEC (Bendix Field Engineering Corporation), 1983. Preliminary Hydrochemical Characterization of the Durango, Colorado, Tailings and Raffinate Ponds Areas, GJ-03(83), prepared by BFEC, Grand Junction, Colorado, for the U.S. Department of Energy, Grand Junction, Colorado.

Bopp et al. (B. A. Bopp, R. C. Sanders, and J. W. Kesterson), 1982. Drug Melab. Rev., Vol. 13, pp. 271-318.

BOR (Bureau of Reclamation), 1990. Hydrogeochemical Site Characterization, Durango Pumping Plant - Animas La Plata Project, Durango Projects Office, U.S. Department of the Interior, Bureau of Reclamation, November 1990.

BOR (Bureau of Reclamation), 1980. Animas-La Plata Project, Colorado-New Mexico Final Environmental Impact Statement, INT-FES 80-18, prepared by Upper Colorado Region, U.S. Department of the Interior, Bureau of Reclamation, Salt Lake City, Utah.

Brater, C. D., 1992. "Treatment of Renal Disorders and the Influence of Renal Function on Drug Disposition," in Clinical Pharmacology, Vol. 31, pp. 776-785.

Brookins, D. G., 1988. Eh-pH Diagrams for Geochemistry, Springer-Verlag, New York, New York.

Buchet et al. (J. P. Buchet, R. Lauwerys, and H. Roels), 1990. "Renal Effects of Cadmium Body Burden of the General Population," in Lancet, Vol. 336, pp. 669-702. 
Buchet et al. (J. P. Buchet, R. Lauwerys, and H. Roels), 1981. "Urinary Excretion of Inorganic Arsenic and its Metabolites After Repeated Ingestion of Sodium Metaarsenite by Volunteers", in International Archives of Occupational and Environmental Health, No. 48, pp. 111-118.

Buchet et al. (J. P. Buchet, H. Roels, and R. Lauwerys), 1980. "Repeated Surveillance of Exposure to Cadmium, Manganese, and Arsenic in School-Age Children Living in Rural, Urban, and Nonferrous Smelter Areas in Belgium," in Environmental Research, No. 22, pp. 95-108.

Burton, G.A., Jr., 1991. "Assessing the Toxicity of Freshwater Sediments," in Environmental Toxicology and Chemistry, No. 10, pp. 1585-1627.

Butler, David L., 1986. General Surface-and Ground-Water Quality in a Coal-Resource Area near Durango, Southwestern Colorado, U.S. Department of the Interior, U.S. Geological Survey, Water Resources Investigations Report 86-4073, 53 pp.

Byerrum et al. (R. U. Byerrum, R. E. Eckardt, L. L. Hopkins), 1974. Vanadium, National Academy of Sciences, Washington, D.C.

Byrne, A. R., and L. Kosta, 1978. Sci. Total Environ., Vol. 10, pp. 17-30.

Calabrese, E. J., and R. W. Tuthill, 1977. "Elevated Blood Pressure and High Radium Levels in The Public Drinking Water," in Archives of Environmental Health, September/October 1977, pp. 200-202.

Carson et al. (B. L. Carson, H. V. Ellis III, and J. L. McCann), 1986. Toxicology and Biological Monitoring of Metals in Humans, Lewis Publishers, Inc., New York, New York, pp. 226-230.

Casarett, L. J., and J. Doull, 1991. Toxicology: The Basic Science of Poisons, fourth edition, Macmillan Publishing Company, New York, New York.

CDPHE (Colorado Department of Health), 1991. Basic Standards and Methodologies for Surface Water, 3.1.0., Water Quality Control Commission, Denver, Colorado.

CDPHE (Colorado Department of Health), 1990. "Ground Water Quality Standards," 3.11.5A, The Basic Standards for Ground Water, Water Quality Control Commission, Denver, Colorado.

Chapman, P.M., 1989. "Current Approaches to Developing Sediment Quality Criteria," in Environmental Toxicology and Chemistry, No. 8, pp. 598-599.

Cothern, C. R., and W. L. Lappenbusch, 1983. "Occurrence of Uranium in Drinking Water in the United States," in Health Physics, No. 45, pp. 89-99.

Crecelius, E. A., 1977. "Changes in the Chemical Speciation of Arsenic Following Ingestion by Man," in Environmental Health Perspective, No. 19, pp. 147-150. 
Cummins, L. M., and E. T. Kimura, 1971. Toxicological Applied Pharmacology, Vol. 20, pp. 89-96.

Curran et al. (G. L. Curran, D. L. Azarnoff, and R. E. Bolinger), 1959. Journal of Clinical Investigation, Vol. 38, pp. 1251-1261.

Dames \& Moore, 1983. Preliminary Draft Environmental Impact Statement, Remedial Actions at the Former Vanadium Corporation of America Uranium Mill Site. Durango, La Plata County, Colorado, November 1983.

DHHS (U.S. Department of Health and Human Services), 1993a. Toxicological Profile for Arsenic, prepared by Life Systems, Inc., for Clement International Corporation

DHHS (U.S. Department of Health and Human Services), 1993b. Toxicological Profile for Cadmium, U.S. Department of Health and Human Services, Atlanta, Georgia.

DHHS (U.S. Department of Health and Human Services), 1993c. Toxicological Profile for Lead, U.S. Department of Health and Human Services, Atlanta, Georgia.

DHHS (U.S. Department of Health and Human Services), 1992a. Toxicological Profile for Antimony and Compounds, prepared by Syracuse Research Corporation for the U.S. Department of Health and Human Services, Public Health Service, Agency for Toxic Substances and Disease Registry.

DHHS (U.S. Department of Health and Human Services), 1992b. Toxicological Profile for Manganese, U.S. Department of Health and Human Services, Atlanta, Georgia.

DHHS (U.S. Department of Health and Human Services), 1992c. Toxicological Profile for Thallium, prepared by Life Systems, Inc. for the U.S. Department of Health and Human Services, Public Health Service, Agency for Toxic Substances and Disease Registry.

DHHS (U.S. Department of Health and Human Services), 1989. Toxicological Profile for Selenium, U.S. Department of Health and Human Services, Atlanta, Georgia.

Dimond et al. (E. G. Dimond, J. Caravaca, and A. Benchimol), 1963. "Vanadium: Excretion, Toxicity, Lipid Effect in Man," American Journal of Clinical Nutrition, Vol. 12, pp. 49-53.

Di Toro et al. (D.M. Di Toro, C.S. Zarba, D.J. Hansen, W.J. Berry, R.C. Swartz, C.E. Cowan, S.P. Pavlou, H.E. Allen, N.A. Thomas, and P.R. Paquin), 1991. "Technical Basis for Establishing Sediment Quality Criteria for Nonionic Organic Chemicals Using Equilibrium Partitioning," in Environmental Toxicology and Chemistry, No. 10, pp. 1541-1583. 
DOE (U.S. Department of Energy), 1994. Human Health Risk Assessment Methodology for the UMTRA Ground Water Project, DOE/AL/62350-170, Rev. O, November 1994, U.S. Department of Energy, UMTRA Project Office, Albuquerque Operations Office, Albuquerque, New Mexico.

DOE (U.S. Department of Energy), 1991. "Attachment 3, Groundwater Hydrology Report," Remedial Action Plan and Site Design for Stabilization of the Inactive Uranium Mill Tailings Site at Durango, Colorado, UMTRA-DOE/AL-050503.0000, U.S. Department of Energy, UMTRA Project Office, Albuquerque Operations Office, Albuquerque, New Mexico.

DOE (U.S. Department of Energy), 1990. Requirements for Quality Control of Analytical Data, DOE/HWP-65/RI, U.S. Department of Energy, Hazardous Waste Remedial Actions Program, $96 \mathrm{pp}$.

DOE (Department of Energy), 1985. Final Environmental Impact Statement, Remedial Actions at the Former Vanadium Corporation of America Uranium Mill Site. Durango, La Plata County, Colorado, DOE/EIS-0111F, October 1985, U.S. Department of Energy, UMTRA Project Office, Albuquerque Operations Office, Albuquerque, New Mexico.

DOE (U.S. Department of Energy), 1983. Preliminary Draft Environmental Impact Statement, Uranium Mill Tailings Remedial Action Program, Durango Site, Durango, La Plata County, Colorado, November 1983, U.S. Department of Energy, UMTRA Project Office, Albuquerque Operations Office, Albuquerque, New Mexico.

Eisler, R., 1989. "Molybdenum Hazards to Fish, Wildlife, and Invertebrates: A Synoptic Review," U.S. Fish and Wildlife Service, Contaminant Hazard Reviews, Report 19. U.S. Department of the Interior, Washington D.C.

Elinder, C. G., 1986. Handbook on the Toxicology of Metals, L. Friberg, G. F. Nordberg, and V. Houk, eds., second edition, Elsevier Science Publishers, Amsterdam.

EPA (U.S. Environmental Protection Agency), 1994a. Integrated Risk Information System (IRISI, database, Office of Research and Development, Washington, D.C.

EPA (U.S. Environmental Protection Agency), 1994b. Health Effects Assessment Summary Tables (HEAST), annual update, March 1994, 9200.6-303 (94-1), Office of Solid Waste and Emergency Response, Washington, D.C.

EPA (U.S. Environmental Protection Agency), 1992a. Drinking Water Criteria Document for Sulfate, final, Health and Environmental Criteria Division, Office of Science and Technology, U.S. Environmental Protection Agency. 
EPA (U.S. Environmental Protection Agency), 1992b. "Developing a Work Scope for Ecological Assessments," in Eco Update, intermittent bulletin, Vol. 1, No. 4, U.S. Environmental Protection Agency, Office of Emergency and Remedial Response, Hazardous Site Evaluation Division, Washington, D. C.

EPA (U.S. Environmental Protection Agency), 1991. Water Quality Criteria Summary, May 1991, Office of Science and Technology, Health and Ecological Criteria Division, Ecological Risk Assessment Branch, Human Risk Branch, Washington, D.C.

EPA (U.S. Environmental Protection Agency), 1989a. Risk Assessment Guidance for Superfund, Volume I, Human Health Evaluation Manual, EPA/540/1-89/002, Office of Emergency and Remedial Response, Washington, D.C.

EPA (U.S. Environmental Protection Agency), 1989b. Risk Assessment Guidance for Superfund, Volume II, Environmental Evaluation Manual, EPA/540/1-89/001, Office of Emergency and Remedial Response, Washington, D.C.

EPA (U.S. Environmental Protection Agency), 1989c. Drinking Water Criteria Document for Uranium, external review draft, Criteria and Standards Division, Office of Drinking Water, Washington, D.C.

EPA (U.S. Environmental Protection Agency), 1989d. Briefing Report to the EPA Science Advisory Board on the Equilibrium Partitioning Approach to Generating Sediment Quality Criteria, Office of Water Regulations and Standards, Criteria and Standards Division, Washington, D.C.

EPA (U.S. Environmental Protection Agency), 1987. "Health Effects Assessment for Vanadium and Compounds," July 1987, U.S. Environmental Protection Agency, Environmental Criteria and Assessment Office, Cincinnati, Ohio.

EPA (U.S. Environmental Protection Agency), 1986. Quality Criteria for Water, EPA 440/5-86-001, Office of Regulations and Standards, Washington, D.C.

EPA (U.S. Environmental Protection Agency), 1984. Health Assessment Document: Inorganic Arsenic, U.S. Environmental Protection Agency, Washington, D.C.

EPA (U.S. Environmental Protection Agency), 1980. Ambient Water Quality Criteria for Selenium, EPA 440/5-80-070, NTIS PB 81-117814, prepared by the Office Of Health and Environmental Assessment, Environmental Criteria and Assessment Office, Cincinnati, Ohio, for the Office of Water Quality Planning Standards, Washington, D.C.

EPA (U.S. Environmental Protection Agency), 1977. Scientific and Technical Assessment Report on Vanadium, EPA-600-6-77-002, U.S. Environmental Protection Agency, Washington, D.C.

Evans, Anthony M., 1987. An Introduction to Ore Geology, Blackwell Scientific Publications, Boston, Massachusetts, $358 \mathrm{pp}$. 
Ferm, V. H., 1971. "The Teratogenic Profile of Sodium Arsenate in the Golden Hamster," in Archives of Environmental Health, No. 22, pp. 557-560.

Fisenne et al. (I. M. Fisenne, P. M. Perry, and N. H. Harley), 1988. "Uranium in Humans," in Radiation Protection Dosimetry, No. 24, pp. 127-131.

Flanagan et al. (P. R. Flanagan, J. S. McLellan, J. Haist, M. G. Cherian, M. J. Chamberlain, and L. S. Valberg), 1978. Gastroenterology, Vol. 74, pp. 841-846.

Foulkes, E.C., 1990. "The Concept of Critical Levels of Toxic Heavy Metals in Target Tissues," in Toxicology, Vol. 20, No. 5, pp. 327-339.

Freeze, R. A., and J. A. Cherry, 1979. Ground-Water, Prentice-Hall, Inc., Englewood Cliffs, New Jersey.

Freis, E. D., 1976. "Salt, Volume and the Prevention of Hypertension," in Circulation, Vol. 53, No. 4, pp. 589-595.

Friberg et al. (L. Friberg, G. F. Nordberg, and V. B. Vouk), 1986. Handbook on the Toxicology of Metals, Volume II: Specific Metals, second edition, Elsevier, New York, New York.

Gosselin et al. (R. E. Gosselin, H. C. Hodge, and R. P. Smith), 1976. Clinical Toxicology of Commercial Products, fourth edition, Williams and Wilkins, Baltimore, Maryland.

Goyer, Robert A., 1991. "Toxic Effects of Metals," in Casarett and Doull's Toxicology: The Basic Science of Poisons, pp. 623-680, fourth edition, M. O. Amdur, J. Doull, and C. D. Klaassen, eds., Pergamon Press, New York, New York.

Hadjimarkos, D. M., 1968. Adv. Oral Biol., Vol. 3, pp. 253-292.

Hadjimarkos, D. M., 1966. Nature, Vol. 209, pp. 1137.

Hageman, E., 1994. "Draft River Plan Challenges Site of A-LP Plant," in Durango Herald, written by Eric Hageman, Assistant City Editor, 3 June 1994.

Harris et al. (W. R. Harris, S. B. Friedman, and D. Silberman), 1984. Journal of Inorganic Biochemistry, Vol. 20, pp. 157-169.

Heard, M. J., and H. C. Chamberlain, 1982. "Effect of Minerals and Food on Uptake of Lead From the Gastrointestinal Tract in Humans," in Human Toxicology, Vol. 1 , pp. 441-445.

Hoch, G., 1994. Greg Hoch, City of Durango Planning Office, meeting with Barbara Malczewska-Toth, TAC toxicologist, regarding land and water use near the Durango UMTRA Project Site, 16 June 1994, UPDCC File Location No. 3.19.7. 
Hood, R. D., 1972. "Effects of Sodium Arsenite on Fetal Development," in Bulletin of Environmental Contamination and Toxicology, No. 7, p. 216.

IARC (International Agency for Research on Cancer), 1987. IARC Monographs on the Evaluation of the Carcinogenic Risk of Chemicals to Humans, Supplement 7.

ICRP (International Commission on Radiological Protection), 1960. ICRP Publ., 2.

Ishinishi et al. (N. Ishinishi, K. Tsuchiya, M. Vahter, and B. A. Fowler), 1986. "Arsenic," in Handbook on the Toxicology of Metals, Volume II: Specific Metals, second edition, Elsevier Press Science Publishers B.V., Amsterdam.

Israeli, M., and C. B. Nelson, 1992. "Distribution and Expected Time of Residence for U.S. Households," in Risk Analysis, Vol. 13, No. 1, pp. 65-72.

JEG (Jacobs Engineering Group Inc.), n.d. Albuquerque Operations Manual, standard operating procedures, prepared by Jacobs Engineering Group Inc. for the U.S. Department of Energy, UMTRA Project Office, Albuquerque Operations Office, Albuquerque, New Mexico.

Kjellström, T., 1979. Environmental Health Perspective, Vol. 28, pp. 169-197.

Kondakis et al. (X. G. Kondakis, N. Makris, M. Leotsinidis, M. Prinou, and T. Papapetropoulos), 1989. "Possible Health Effects of High Manganese Concentration in Drinking Water," in Archives of Environmental Health, 1989, Vol. 44, No. 3, pp. 175-178.

Krauskopf, K. B., 1979. Introduction to Geochemistry, second edition, McGraw-Hill, New York, New York.

Lagerkvist et al. (B. Lagerkvist, G. F. Nordberg, and V. Vouk), 1986. "Vanadium," in Handbook on the Toxicology of Metals, second edition, L. Friberg, G. F. Nordberg, and V. Vouk, eds., Elsevier Science Publishers, New York, New York.

Leach et al. (L. J. Leach, R. M. Gelein, B. J. Panner, C. L. Ylie, and C. C. Cox), 1984. The Acute Toxicity of the Hydrolysis Products of Uranium Hexafluoride (UF6) When Inhaled by the Rat and Guinea Pig, final report, ISS KISUB-81-9039-3, NTIS DE84011539.

Lindgren et al. (A. Lindgren, M. Vahter, and L. Dencker), 1982. "Autoradiographic Studies on the Distribution of Arsenic in Mice and Hamsters Administered ${ }^{74}$ As-arsenite or -arsenate," in Acta Pharmacology and Toxicology, No. 51, pp. 253-265.

Lönnerdal et al. (B. Lönnerdal, C. L. Keen, J. G. Bell, and B. Sandstrom), 1987. "Manganese Uptake and Retention," in Nutritional Bioavailability of Manganese, C. Kies, ed., American Chemical Society, symposium series 354, pp. 9-20, American Chemical Society, Washington, D.C. 
Marcus, W. L., and A. S. Rispin, 1988. "Threshold Carcinogenicity Using Arsenic as an Example," in Advances in Environmental Toxicology, Volume XV, Risk Assessment and Risk Management of Industrial and Environmental Chemicals, C. R. Cothern, M. A. Mehlman, and W. L. Marcus, eds., Princeton Scientific Publishing Co., New Jersey, pp. 133-159.

Marafante, E., and M. Vahter, 1987. "Solubility, Retentions and Metabolism of Intratracheally and Orally Administered Inorganic Arsenic Compounds in Hamsters," in Environmental Research, No. 42, pp. 72-82.

Maynard, E. A., and H. C. Hodge, 1949. "Study of Toxicity of Various Uranium Compounds When Fed to Experimental Animals," in Pharmacology and Toxicology of Uranium Compounds, National Nuclear Energy Services, Div. VI, Vol. 1, pp. 309-376, C. Voegtlin and H. C. Hodge, eds., McGraw Hill, New York, New York.

Medinsky et al. (M. A. Medinsky, R. G. Cuddihy, and R. O. McClellan), 1981. J. Toxicol. Environ. Health, Vol. 8, pp. 917-928.

Mena et al. (I. Mena, K. Horiuchi, K. Burke, and G. C. Cotzias), 1969. "Chronic Manganese Poisoning: Individual Susceptibility and Absorption of Iron," in Neurology, No. 19, pp. 1000-1006.

Meneely, G. R., and H. D. Battarbee, 1976. "Sodium and Potassium," in Nutrition Reviews, No. 8, pp. 225-235.

Merritt, R. C., 1971. The Extractive Metallurgy of Uranium, Colorado School of Mines Research Institute, Golden, Colorado.

Millar et al. (K. R. Millar, M. A. Gardiner, and A. D. Sheppard), 1973. New Zealand Journal of Agricultural Research, Vol. 16, pp. 115-127.

Morrison et al. (G. M. P. Morrison, G. E. Batley, and T. M. Florence), 1989. "Metal Speciation and Toxicity," in Chem. Br., No. 25, p. 791.

NAS (National Academy of Sciences), 1972. "Airborne Lead in Perspective:

Biologic Effects of Atmospheric Pollutants," in Lead, National

Academy of Sciences, Washington, D.C., pp. 71-177 and

pp. 281-313.

National Research Council, 1989. Recommended Dietary Allowances, tenth edition, National Academy Press, Washington, D.C.

National Research Council, 1980. Drinking Water and Health, Volume 3, Safe Drinking Water Committee. 
National Research Council, 1973. Medical and Biological Effects of Environmental Pollutants: Manganese, Committee on Biologic Effects of Atmospheric Pollutants, Division of Medical Sciences.

NCRP (National Council on Radiation Protection and Measurements), 1984. "Exposures from the Uranium Series with Emphasis on Radon and its Daughter," NCRP Report No. 77, Bethesda, Maryland.

NOAA (National Oceanic and Atmospheric Administration), 1990. "The Potential for Biological Effects of Sediment-Sorbed Contaminants Tested in the National Status and Trends Program," NOAA technical memo, NOS OMA 52.

Nordberg et al. (G. F. Nordberg, T. Kjellström, and M. Nordberg), 1985. Cadmium and Health: a Toxicological and Epidemiological Appraisal, L. Friberg, C. G. Elinder, T. Kjellström, and G. F. Nordberg, eds., CRC Press, Boca Raton, Florida.

OMOE (Ontario Ministry of the Environment), 1990. "The Provisional Sediment Quality Guidelines," prepared by D. Persaud, R. Jaagumagi, and A. Hayton, Water Resources Branch, Ontario Ministry of the Environment, Toronto, Ontario.

Palisade Corporation, 1992. @RISK, Risk Analysis and Simulation Add-In for Lotus 1-2-3, Version 2.01, Newfield, New York.

Parkhurst et al. (D. L. Parkhurst, D. C. Thorstenson, and L. N. Plummer), 1980. "PHREEOE-A Computer Program for Geochemical Calculations," U.S. Geological Survey, Water Resources Investigation 80-96, National Technical Information Service Report PB81-167-801, Springfield, Virginia.

Pennington, Jean A., and John W. Jones, 1987. "Molybdenum, Nickel, Cobalt, Vanadium, and Strontium in Total Diets," in Journal of the American Dietetic Association, Vol. 87, No. 12, December 1987, American Dietetic Association, Division of Nutrition and Division of Contaminants Chemistry, Center for Food Safety and Applied Nutrition, Food and Drug Administration, Washington, D.C.

Perry et al. (H. M. Perry, Jr., S. Teitlebaum, and P. L. Schwartz), 1955. Fed. Proc., Vol. 14, pp. 113-114.

Pershagen, G., and M. Vahter, 1979. Arsenic, Swedish Environmental Protection Board, Stockholm, Sweden.

Prister, B. S., 1969. GKIAE Report by Atomizdat, Moscow (Canadian translation AEC/TR/7178 (1970), and USCEAR Rep. A/AC.82/G/L 1298).

Proescher et al. (F. Proescher, H. A. Seil, and A. W. Stillians), 1917. Am. J. Syph., Vol. 1, pp. 347-405. 
Rai, D., and J. M. Zachara, 1984. Chemical Attenuation Rates, Coefficients, and Constants in Leachate Migration, Volume 1: A Critical Review, EPRI, EA-3356, Volume 1, Research Project 2188-1.

Robinson et al. (M. F. Robinson, J. M. McKenzie, C. Thomson, and A. L. Van Rijn), 1973. Br. J. Nutr., Vol. 30, pp. 195-205.

Rogers, O., 1994. Otha J. Rogers, P.E., City of Durango, City Engineer, meeting with Barbara Malczewska-Toth, TAC toxicologist, regarding water use near the Durango UMTRA Project Site, 16 June 1994, UPDCC File Location No. 3.19.17.

Roseberry, A. M., and D. E. Burmaster, 1992. "Lognormal Distributions for Water Intake by Children and Adults," in Risk Analysis, Vol. 12, No. 1, pp. 99-104.

Rosenfeld, I., and O. A. Beath, 1964. Selenium, Geobotany, Biochemistry, Toxicity, and Nutrition, Academic Press, New York, New York.

Rosoff, B., and H. Spencer, 1964. Nature (London), Vol. 202, pp. 410-411.

Saric, M., 1986. "Manganese," in Handbook on the Toxicology of Metals, Volume II, pp. 354-386, L. Friberg, G. F. Nordberg, V. B. Vouk, eds., Elsevier, New York.

Schroeder et al. (H. A. Schroeder, J. J. Balassa, and I. H. Tipton), 1963. Journal of Chronic Diseases, Vol. 16, pp. 1047-1071.

Shannon, R. L., and D. S. Strayer, 1989. "Arsenic-Induced Skin Toxicity," in Human Toxicology, No. 8, pp. 99-104.

Shea, D., 1988. "Developing National Sediment Quality Criteria," in Environmental and Scientific Technology, No 22(11), pp. 1256-1261.

Snyder, F., and W. E. Cornatzer, 1958. Nature, Vol. 182, pp. 462.

Somerville, J., and B. Davies, 1962. Am. Health J., Vol. 54, pp. 54-56.

Stevens et al. (W. F. Stevens, W. Bruenger, D. R. Atherton, J. M. Smith, and

G. N. Taylor), 1980. "The Distribution and Retention of Hexavalent ${ }^{233} U$ in the Beagle," in Radiation Research, No. 83, pp. 109-126.

Sullivan et al. (M. F. Sullivan, P. S. Ruemmler, J. L. Ryan, and R. L. Bushhom), 1986. "Influence of Oxidizing or Reducing Agents on Gastrointestinal Absorption of $U$, Pu, Am, Cm, and Pm by Rats," in Health Physics, No. 50, pp. 223-232. 
TAC (Technical Assistance Contractor), 1995. "Supplement to the Baseline Risk Assessment of Ground Water Contamination at the Uranium Mill Tailings Site Near Durango, Colorado," unpublished data prepared by the TAC for the U.S. Department of Energy, available in the UMTRA Project Document Control Center, UMTRA Project Office, Albuquerque Operations Office, Albuquerque, New Mexico.

TAC (Technical Assistance Contractor), 1994a. "Land and Water Use Survey, Durango, Colorado site, 16-17 June 1994," unpublished report prepared by the TAC (Jacobs-Weston team), Albuquerque, New Mexico, for the U.S. Department of Energy, UMTRA Project Office, Albuquerque Operations Office, Albuquerque, New Mexico, UPDCC File Location No. 3.19.7.

TAC (Technical Assistance Contractor), 1994b. "Surface Water and Sediment Sampling at Durango UMTRA Project site," memorandum dated 13 January 1994, JEGE/JEG/0194-0016.

Tame et al. (K. E. Tame, E. G. Valdez, and J. B. Rosenbaum, 1961. Disposal of Liquid Waste in the Durango-Type Milling Flowsheet, U.S. Department of Interior, Bureau of Mines, Report of Investigations 5874, 12 pp.

Tank, G., and C. A. Storvick, 1960. Journal of Dental Research, Vol. 39, pp. 473-488.

Tipton et al. (I. H. Tipton, P. L. Stewart, and J. Dickson), 1969. Health Physics, Vol. 9, pp. 103-145.

Tracy et al. (B. L. Tracy, J. M. Quinn, J. Lahey, A. P. Gilman, K. Mancuso, A. P. Yagdinas, and D. C. Villeneuve), 1992. "Absorption and Retention of Uranium from Drinking Water by Rats and Rabbits," in Health Physics, Vol. 62, pp. 65-73.

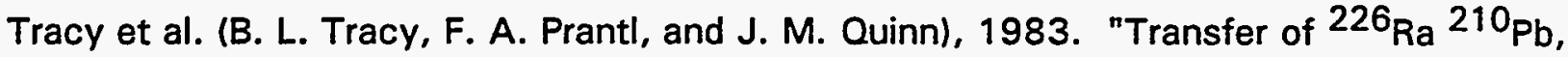
and Uranium from Soil to Garden Produce: Assessment of Risk," in Health Physics, Vol. 44, p. 469.

Tseng, W. P., 1977. "Effects and Dose-Response Relationship of Skin Cancer and Blackfoot Disease with Arsenic," in Environmental Health Perspectives, No. 19, pp. 109-119.

Tsivoglou et al. (E. C. Tsivoglou, S. D. Shearer, J. D. Jones, C. E. Sponagle, H. R. Pahren, J. B. Anderson, and D. A. Clark, 1960. Survey of Interstate Pollution of the Animas River (Colorado-New Mexico) II, 1959 Surveys, U. S. Department of Health, Education, and Welfare, Public Health Service, Bureau of State Services, Division of Water Supply and Pollution Control, 18 pp.

USGS (U.S. Geological Survey), 1993. Water Resources Data for Colorado Water, 1992, Vol. 2, Colorado River Basin, National Technical Information Service, Springfield, Virginia. 
Van Zinderen Bakker and J. F. Jaworski, 1980. Effects of Vanadium in the Canadian Environment, Ottawa, Canada: National Research Council Canada, Associate Committee Scientific Criteria for Environmental Quality.

Venugopal, B., and T. D. Luckey, 1978. "Chemical Toxicity of Metals and Metalloids," in Metal Toxicity in Mammals, Plenum Press, New York, New York.

Webb, J. L., 1966. Enzymes and Metabolic Inhibitors, Academic Press, New York, New York.

Weigel, F., 1983. "Uranium and Uranium Compounds," in Kirk-Othmer Encyclopedia of Chemical Technology, Vol. 23, third edition, pp. 502-547, M. Grayson, ed., John Wiley and Sons, New York, New York.

WHO (World Health Organization), 1988. Vanadium, Environmental Health Criteria 81, published under the joint sponsorship of the United Nations Environment Programme, the International Labour Organisation, and the World Health Organization, Geneva, Switzerland.

WHO (World Health Organization), 1981. Arsenic, Environmental Health Criteria 18, published under the joint sponsorship of the United Nations Environment Programme, the International Labour Organisation, and the World Health Organization, Geneva, Switzerland.

WHO (World Health Organization), 1977. Lead, Environmental Health Criteria 3, published under the joint sponsorship of the United Nations Environment Programme, the International Labour Organisation, and the World Health Organization, Geneva, Switzerland.

Will, M. E., and G. W. Suter II, 1994. Toxicological Benchmarks for Screening Potential Contaminants of Concern for Effects on Terrestrial Plants, ES/ER/TM-85/R1, 1995 revision, Oak Ridge National Laboratory, Oak Ridge, Tennessee.

Wrenn et al. (M. E. Wrenn, P. W. Durbin, B. Howard, J. Lipsztein, J. Rundo, E. T. Still, and D. L. Willis), 1985. "Metabolism of Ingested $U$ and $R a, "$ in Health Physics, No. 48 , pp. 601-633.

Yakawa, M., and M. Suzuki-Yasumoto, 1980. Archives of Environmental Health, Vol. 35, pp. 36-44.

Yang et al. (G. Yang, R. Zhou, and S. Yin), 1989a. "Studies of Safe Maximal Daily Dietary Selenium Intake in a Seleniferous Area in China," I, in J. Trace Elem. Electrolytes Health Dis., Vol. 3(2), pp. 77-87. 
Yang et al. (G. S. Yang, R. Zhou, and S. Yin), 1989b. "Studies of Safe Maximal Daily Dietary Selenium Intake in a Seleniferous Area in China, II, Relation Between Selenium Intake and the Manifestation of Clinical Signs and Certain Biochemical Alterations in Blood and Urine," in J. Trace Elem. Electrolytes Health Dis., Vol. 3(2), pp. 123-130.

\section{CODE OF FEDERAL REGULATIONS}

40 CFR Part 192, "Health and Environmental Protection Standards for Uranium and Thorium Mill Tailings," U.S. Environmental Protection Agency (1994).

40 CFR Part 264, "Standards for Owners and Operators of Hazardous Waste Treatment, Storage, and Disposal Facilities," U.S. Environmental Protection Agency (1994).

40 CFR Part 300, "National Oil and Hazardous Substance Pollution Contingency Plan," U.S. Environmental Protection Agency (1994).

FEDERAL REGISTER

60 FR 2854, "Groundwater Standards for Remedial Actions at Inactive Uranium Processing Sites," final rule, U.S. Environmental Protection Agency, January 11, 1995.

\section{UNITED STATES CODE}

42 USC $\$ 7901$ et seq. Uranium Mill Tailings Radiation Control Act, November 8, 1978.

42 USC $\$ 7922$ et seq., Uranium Mill Tailings Remedial Action Amendments Act, November 5, 1988. 